\author{
UNIVERSIDADE DE SÃO PAULO \\ FACULDADE DE CIÊNCIAS FARMACÊUTICAS \\ Programa de Pós-Graduação em Fármaco e Medicamentos \\ Área de Insumos Farmacêuticos
}

\title{
Caracterização farmacognóstica de Campomanesia xanthocarpa Berg Myrtaceae
}

BLANCA ELENA ORTEGA MARKMAN

Dissertação para obtenção do grau de MESTRE

Orientador:

Profa. Dra. Edna Tomiko Myiake Kato 
Ficha Catalogratica

Elaborada pela Divisão de Biblioteca e

Documentação do Conjunto das Químicas da USP.

Markman, Blanca Elena Ortega

M345c Caracterização farmacognóstica de Campomanesia xanthocarpa Berg Myrtaceae / Blanca Elena Oretega Markman.

-- São Paulo, 2002. $169 p$.

Dissertação (mestrado)- Faculdade de Ciências Farmacêuticas da Universidade de São Paulo. Departamento de Farmácia.

Orientador: Kato, Edna Tomiko Myiake

1. Myrtaceae : Farmacognosia 2. Farmacologia 1. T. II. Kato, Edna Tomiko Myiake, orientador. 


\section{BLANCA ELENA ORTEGA MARKMAN}

CARACTERIZAÇÃO FARMACOGNÓSTICA DE

CAMPOMANESIA XANTHOCARPA BERG

\section{MYRTACEAE}

Comissão Julgadora

Dissertação para a obtenção do grau de Mestre

Profa. Dra. Edna Tomiko Myiake Kato

Orientador / Presidente

Profa. Dra. Maria Emilia Maranhão Estelita

$$
1^{\circ} \text { Examinador }
$$

Prof. Dr. Paulo Chanel Deodato

$2^{\circ}$ Examinador

São Paulo, 07 de agosto de 2002 
Para ser grande, sê inteiro: nada Teu exagera ou exclui. Sê todo em cada coisa. Põe quanto és No mínimo que fazes. Assim em cada lago a lua toda Brilha porque alta vive

Fernando Pessoa-1993 
A Deus pela minha existência.......... Aos meus pais, pelos ensinamentos de luta, dedicação e perseverança, meu profundo amor e agradecimento. Ao Luiz Carlos meu marido e companheiro. Aos meus filhos Caroline e Luiz Fernando, que me incentivaram e colaboraram. 
A Profa. Dra Edna T. Myiake Kato, pela dedicada orientação, compreensão, apoio e amizade, minha gratidão 


\section{Agradecimentos}

Ao Dr. Odair Zenebon, Diretor da Divisão de Bromatologia e Química do Instituto Adolfo Lutz, pelo apoio e incentivo.

A Mariângela Tírico Auricchio Diretora do Serviço de Medicamentos do Instituto Adolfo Lutz, pela colaboração e apoio.

A Dra. Maria Lúcia Kawasaki, pesquisadora do Instituto de Botânica de São Paulo, pela identificação da espécie.

Ao Sr. Luiz Benedito Bacher da Fazenda Citra de Limeira, pela gentileza de nos receber, e pelo fornecimento do material de estudo desta dissertação.

A Profa. Elfriede M. Bacchi, pelo apoio e orientação nos ensaios de toxicidade e antiúlcera.

A Profa. Dominique C.H. Fischer pelo uso do fotomicroscópio Nikon .

A Profa. Dra. Silvia Berlanga Morais de Barros pela orientação e colaboração na realização do ensaio de atividade antioxidante.

A Profa. Dra. Dulcineia Abdalla S., a pesar das atribuições que the são devidas, nos recebeu e orientou com dedicação na execução do ensaio de inibição de lipoperoxidação de LDL.

A doutorando Patrícia Moriel, pelo apoio e ensinamentos na realização e interpretação do ensaio de lipoperoxidação de LDL.

A Ivana Barbosa Suffredini da UNIPE pelo apoio na realização do ensaio de letalidade de artêmias.

A Adriana Bugno e Luciene Figueredo da Seção de Esterilidade e Pirogênio do Inst. Adolfo Lutz pelo apoio na realização do ensaio de atividade antimicrobiana. 
A Célia Maria Pompeo Mome da Seção de Desenho do Inst. Adolfo Lutz, pela reprodução e montagem das fotografias que ilustram esta Dissertação.

A Áquila Maria Lourenço Gomes Diretora de Serviços Básicos do Inst. Adolfo Lutz, pela colaboração e apoio.

Ao técnico Roberto Honório de Jesus pela realização dos cortes da folha para estudos anatômicos.

A Heloisa Veloso pela versão para o inglês do resumo.

As bibliotecárias Leila e Adriana do Conjunto das Químicas pela orientação, e revisão das referências bibliográficas.

Aos funcionários do Bloco 15, Betty, Luiz, Lúcia o meu agradecimento pelo carinho e colaboração na elaboração deste trabalho.

Aos pos-graduando Suzana Saito, Roberto Adati, Willan, Helena Onishi pela colaboração, apoio e principalmente pela amizade.

Aos funcionários da Seção de Antibióticos do Inst. Adolfo Lutz, pela compreensão, pelo apoio e incentivo na realização desta Dissertação. 


\section{ÍNDICE GERAL}

páginas

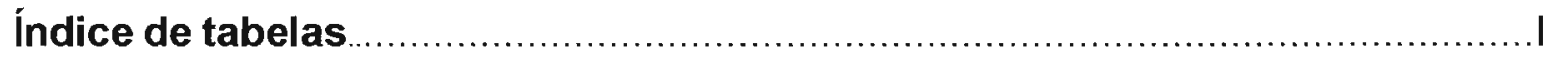

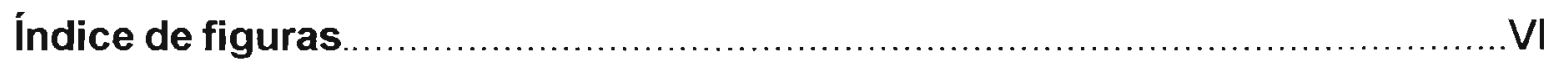

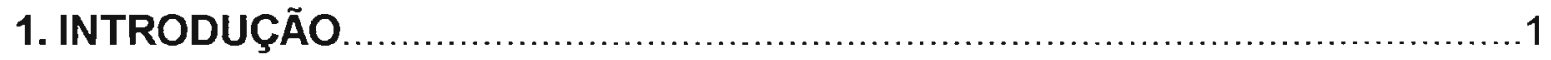

2. GENERALIDADES

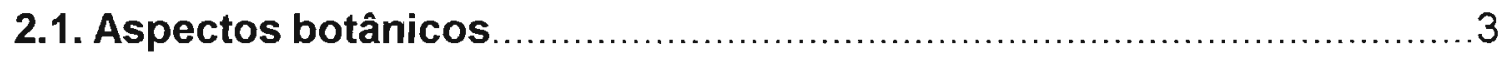

2.1.1. Família Myrtaceae .......................................................................

2.1.2. Gênero Campomanesia ..................................................4

2.1.3. Campomanesia xanthocarpa Berg............................................. 5

2.2. Aspectos químicos e biológicos de Myrtaceae ...............................6

2.3. Tópicos sobre atividade antiúlcera .............................................. 18

2.4. Tópicos sobre atividade antioxidante......................................... 19

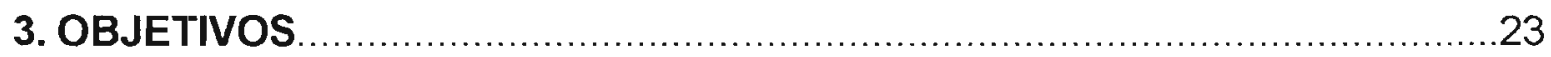

\section{MATERIAL E MÉTODOS}

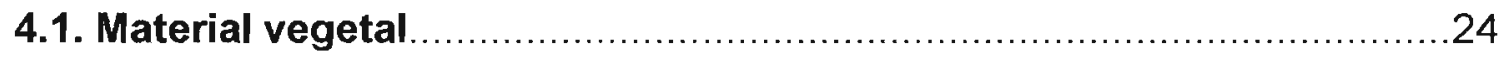

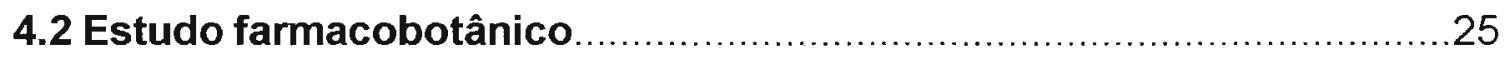

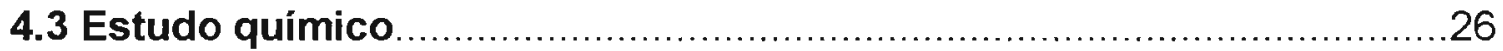

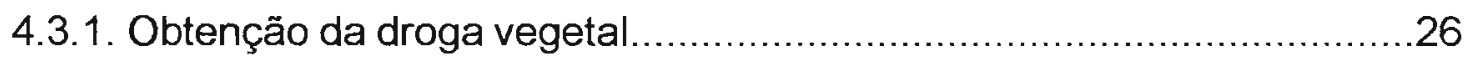

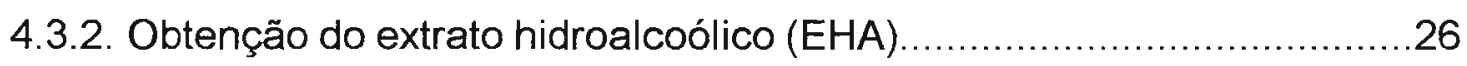

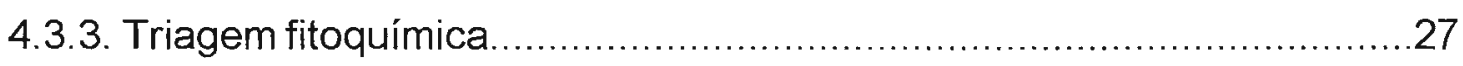

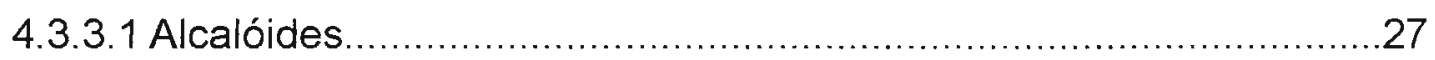

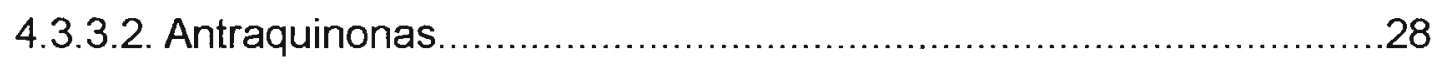

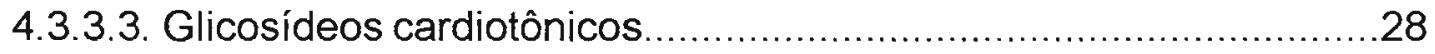

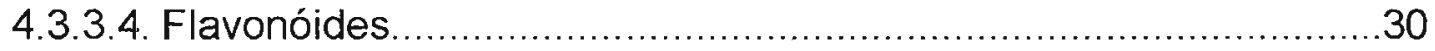

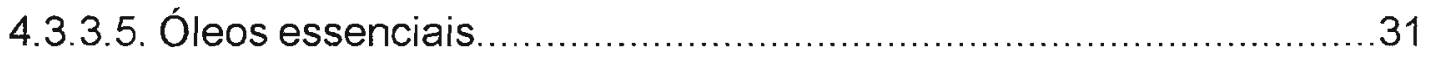


4.3.3.6. Saponinas

4.3.3.7. Taninos

4.3.3.8. Análise cromatográfica em camada delgada dos principais grupos de princípios ativos. 34

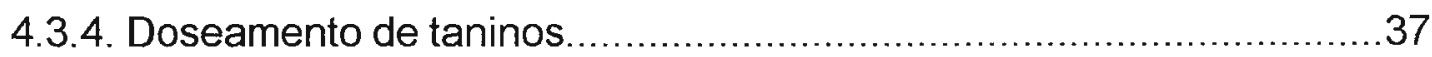

4.3.4.1 Preparo das amostras e da solução do padrão...............................37

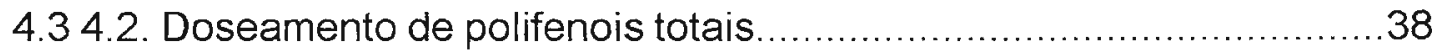

4.3.4.3. Doseamento de polifenois não absorvidos pela pele......................38

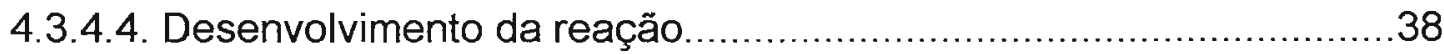

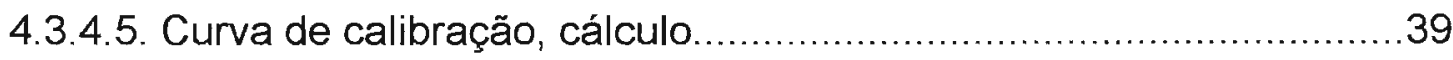

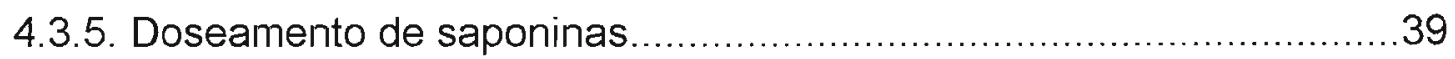

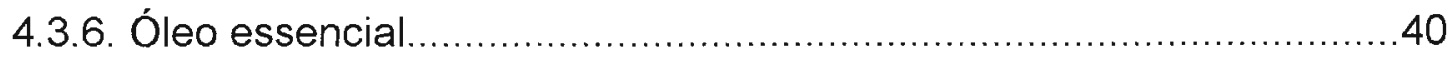

4.3.6.1. Determinação do teor de óleo essencial......................................40

4.3.6.2. Análise do óleo essencial por CG/EM........................................40

\subsection{Ensaios biológicos}

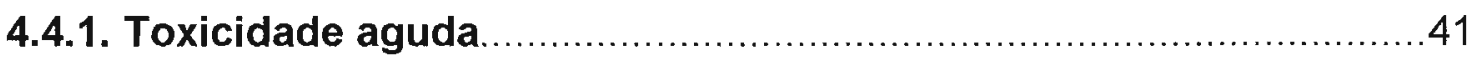

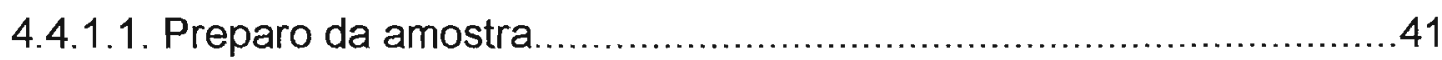

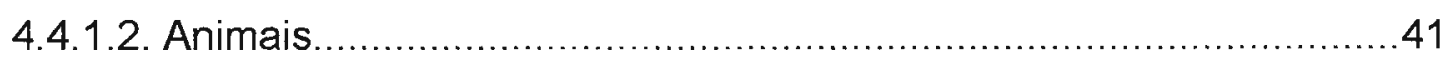

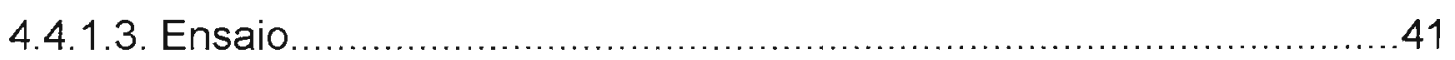

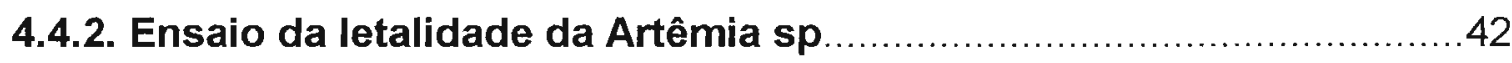

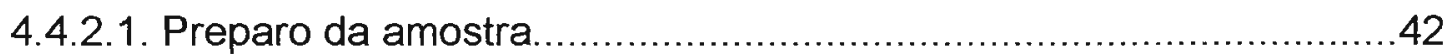

4.4.2.2. Preparo da água de mar artificial e obtenção de artêmias..............42

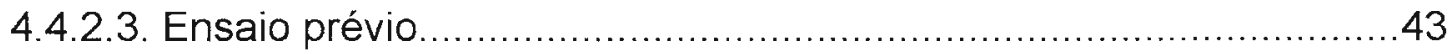

4.4.2.4. Determinação da DL50 do extrato EHA em Aetêmias.....................43

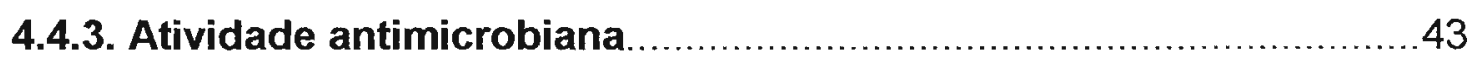

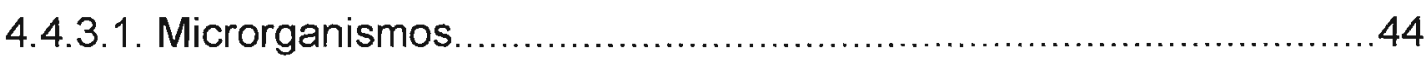

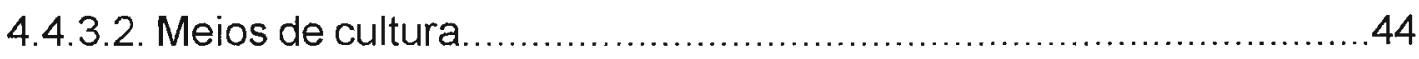

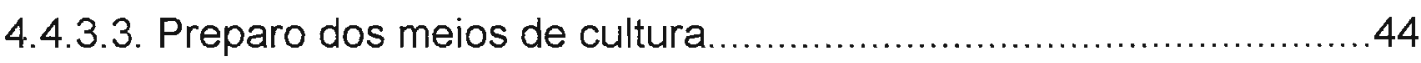

4.4.3.4. Preparo da solução fisiológica estéril........................................44

4.4.3.5. Preparo e padronização das suspensões de microrganismos.......44

4.4.3.6. Preparo das soluções dos antibióticos ..........................................45 


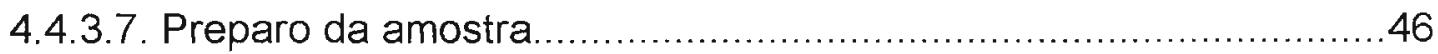

4.4.3.8. Avaliação da atividade antimicrobiana....................................46

4.4.3.9. Avaliação da Concentração Inibitória Mínima..............................46

4.4.4. Atividade antiúlcera............................................................ 47

4.4.4.1. Preparo da amostra ....................................................4 47

4.4.4.2. Preparo do controle positivo (misoprostol) .............................4 47

4.4.4.3. Preparo do controle negativo.............................................4 47

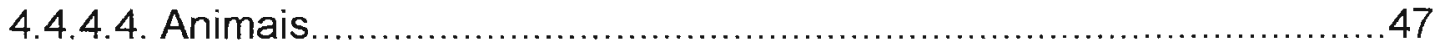

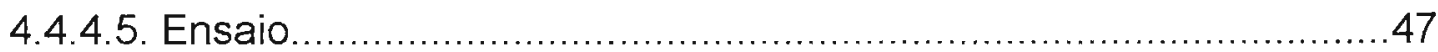

4.4.5. Atividade antioxidante..................................................... 48

4 4.5.1. Cromatografia em camada delgada .............................48

4.4.5.2. Técnica da medida de malonildialdeido (MDA) .......................50

4 4.5.3. Avaliação do efeito do extrato EHA de C. xanthocarpa sobre a cinética de oxidação de LDL induzida por sulfato de cobre. Cálculo de

“Lag-time" e "Peak-time"

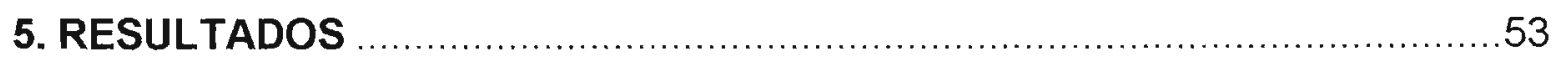

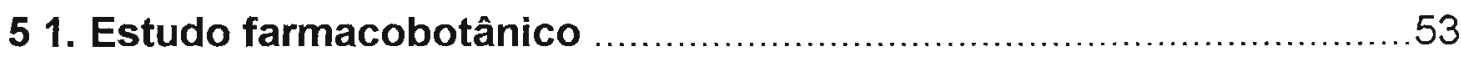

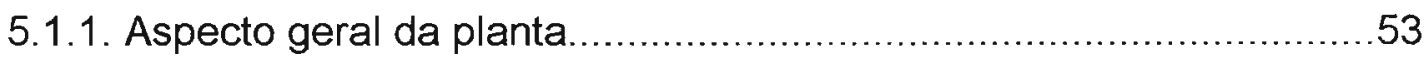

5.1.2. Caracterização macroscópica da droga ....................................53

5.1.3. Caracterização microscópica da droga......................................54

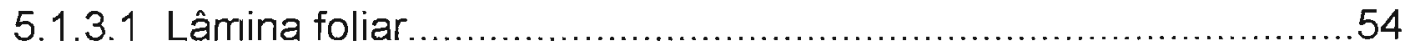

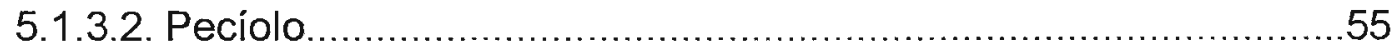

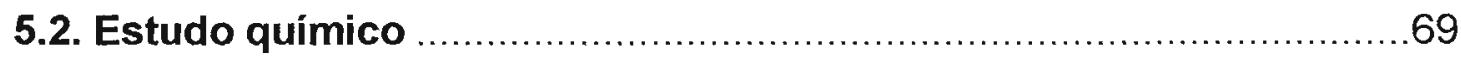

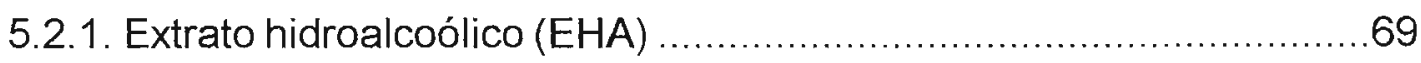

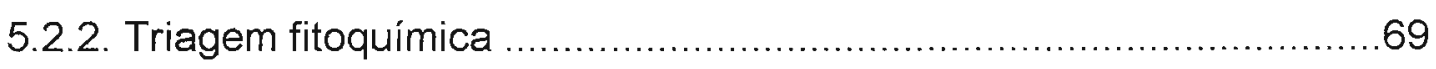

5.2.3. Análise cromatográfica em camada delgada dos principais grupos

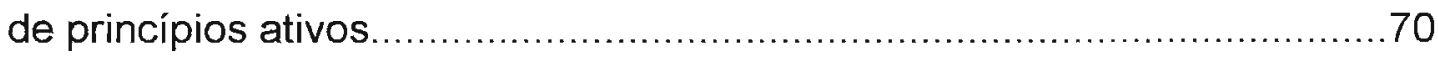

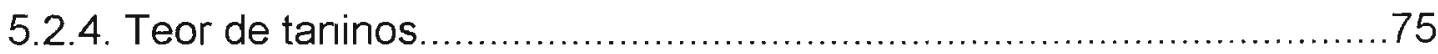

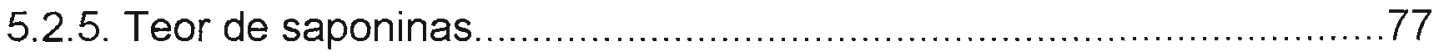

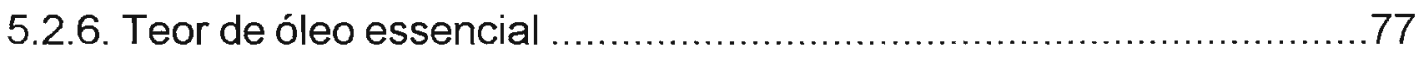


5.2.7. Análise do óleo essencial por CG/EM.......................................77

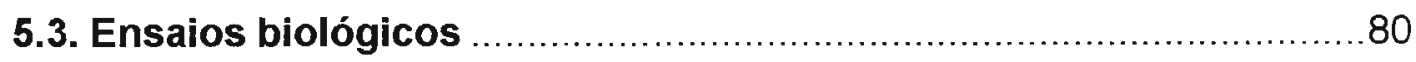

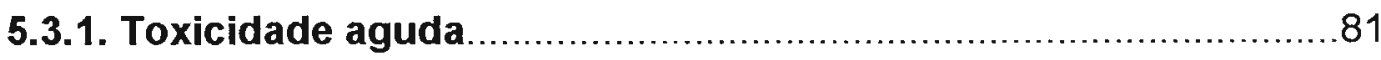

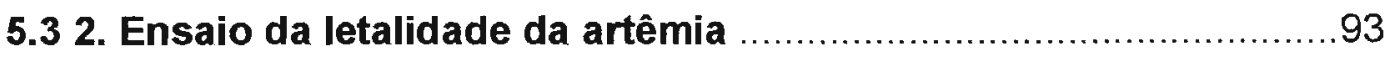

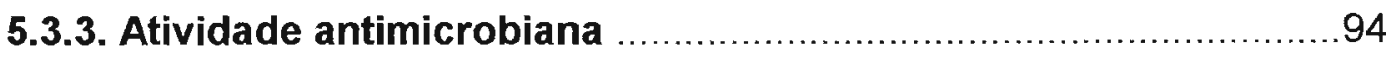

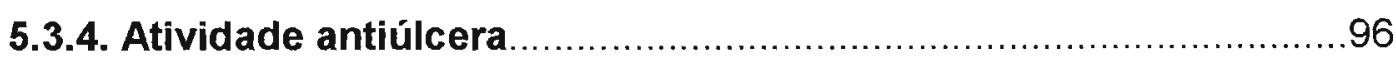

5.3.5. Avaliação da capacidade antioxidante................................. 101

5.3.5.1. Cromatografia em camada delgada.................................... 101

5.3.5.2. Medida da produção de Malonildialdeido (MDA).................... 104

5.3.5.4. Avaliação do efeito do extrato EHA de C. xanthocarpa sobre a cinética de oxidação de LDL induzida por sulfato de cobre..................106

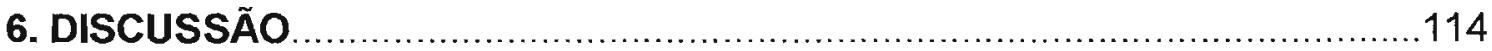

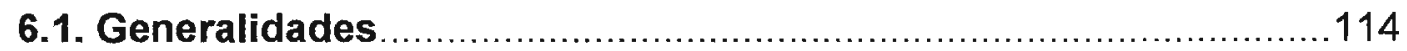

6.2. Aspectos Botânicos............................................................ 115

6.3. Aspectos químicos ...................................................... 116

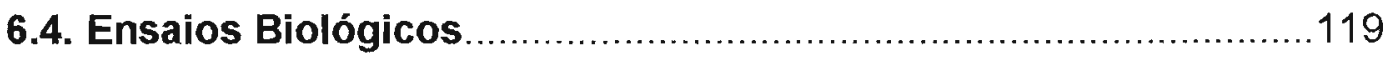

6.4.1. Toxicidade aguda ...................................................... 119

6.4.2. Ensaio de letalidade de artêmias ......................................120

6.4.3. Atividade antimicrobiana................................................ 121

6.4.4. Atividade Antiúlcera ....................................................... 123

6.4.5. Atividade Antioxidante .................................................. 127

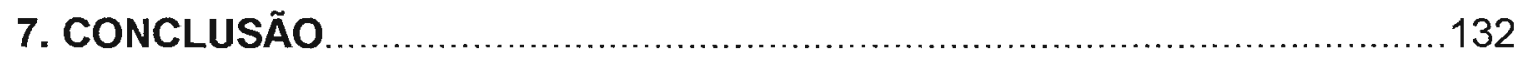

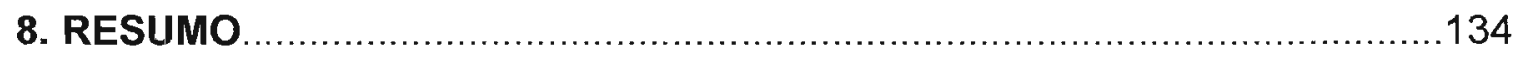

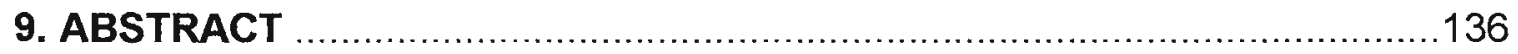

10. REFERÊNCIAS BIBLIOGRÁFICAS ............................................. 138 


\section{INDICE DE TABELAS}

Páginas

Tabela 1. Componentes químicos e atividades biológicas em espécies pertencentes a gêneros de Mirtáceas encontradas no Brasil..

Tabela 2. Material vegetal empregado no estudo. .24

Tabela 3. Triagem fitoquímica da droga e do extrato hidroalcoólico (EHA) preparado a partir de folhas de C. xanthocarpa. 69

Tabela 4. Análise cromatográfica em camada delgada (Sistema 1) dos extratos metanólicos a 0,2 \% do pó da droga, do extrato EHA de C. xanthocarpa e da substância química de referência (SQR) saponina Merck $®$ a 0,05 \%. 71

Tabela 5. Análise cromatográfica em camada delgada (Sistema 2) dos extratos metanólicos a 0,2 \% da droga, do extrato EHA de C. xanthocarpa e das soluções metanólicas a $0,05 \%$ das substâncias químicas de referência (SQR) quercetina, rutina, apigenina, crisina e ácido clorogênico

Tabela 6. Análise cromatográfica em camada delgada (Sistema 3) dos extratos metanólicos a 0,2 \% da droga, do extrato EHA de $C$. xanthocarpa e das soluções metanólicas a $0,05 \%$ das substâncias químicas de referência (SQR) quercetina, rutina, e ácido clorogênico

Tabela 7. Análise cromatográfica em camada delgada (Sistema 4) das soluções clorofórmicas a $1 \%$ do óleo essencial de C. xanthocarpa, e das substâncias químicas de referência (SQR) linalol e acetato de linalila .74

Tabela 8. Análise cromatográfica em camada delgada (Sistema 5) das soluções clorofórmicas a $1 \%$ do óleo essencial das folhas de $C$. xanthocarpa, e das substâncias químicas de referência (SQR) linalol e acetato de linalila .75 
Tabela 9. Principais componentes químicos identificados no óleo essencial obtido de folhas frescas de Campomanesia xanthocarpa através de analise cromatográfica em fase gasosa acoplada a espectrômetro de massas .78

Tabela 10. Consumo de água dos camundongos fêmeas, controle e tratadas por via oral com extrato EHA de C. xanthocarpa na dose de $5 \mathrm{~g} / \mathrm{kg}$ de peso animal no ensaio de toxicidade aguda

Tabela 11. Consumo de ração dos camundongos fêmea, controle e tratados por via oral com o extrato EHA de C. xanthocarpa na dose de $5 \mathrm{~g} / \mathrm{kg}$ de massa do animal no ensaio de toxicidade aguda 82

Tabela 12. Medida da massa corpórea média dos camundongos fêmea, controle e tratados por via oral com o extrato EHA de C. xanthocarpa na dose de $5 \mathrm{~g} / \mathrm{kg}$ de massa animal no ensaio de toxicidade aguda $p>0.05$ .83

Tabela 13. Massa relativa de rins dos camundongos fêmeas, controle e tratados por via oral com o extrato EHA de $C$. xanthocarpa na dose de $5 \mathrm{~g} / \mathrm{kg}$ de massa animal no ensaio de toxicidade aguda $p>0.05$

Tabela 14. Massa relativa de fígados dos camundongos fêmeas, controle e tratados por via oral com o extrato EHA de $C$. xanthocarpa na dose de $5 \mathrm{~g} / \mathrm{kg}$ de massa animal no ensaio de toxicidade aguda $p>0.05$ .85

Tabela 15. Massa relativa de coraçâo e pulmões dos camundongos fêmeas, controle e tratados por via oral com o extrato EHA de C. xanthocarpa na dose de $5 \mathrm{~g} / \mathrm{kg}$ de massa animal no ensaio de toxicidade aguda $p>0.05$ 86 
Tabela 16. Consumo de água dos camundongos machos, controle e tratados por via oral com o extrato EHA de C. xanthocarpa na dose de $5 \mathrm{~g} / \mathrm{kg}$ de peso animal no ensaio de toxicidade aguda.

Tabela 17. Consumo de ração dos camundongos machos, controle e tratados por via oral com o extrato EHA de C. xanthocarpa na dose de $5 \mathrm{~g} / \mathrm{kg}$ de peso animal no ensaio de toxicidade aguda.

Tabela 18. Massa corpórea dos camundongos machos, controle e tratados por via oral com o extrato EHA de C. xanthocarpa na dose de $5 \mathrm{~g} / \mathrm{kg}$ de massa animal no ensaio de toxicidade aguda. $p>0.05$ 89

Tabela 19. Massa relativa dos rins dos camundongos machos, controle e tratados por via oral com o extrato EHA de C. xanthocarpa na dose de $5 \mathrm{~g} / \mathrm{kg}$ de massa animal no ensaio de toxicidade aguda. $p>0.05$ 90

Tabela 20. Massa relativa dos fígados dos camundongos machos controle e tratados por via oral com o extrato EHA de C. xanthocarpa na dose de $5 \mathrm{~g} / \mathrm{kg}$ de massa animal no ensaio de toxicidade aguda. $p>0.05$ 91

Tabela 21. Massa relativa de coração e pulmões dos camundongos machos controle e tratados por via oral com o extrato EHA de C. xanthocarpa na dose de $5 \mathrm{~g} / \mathrm{kg}$ de massa animal no ensaio de toxicidade aguda $p>0.05$ .92

Tabela 22. Avaliação prévia da letalidade das Artêmias com o extrato EHA de C. xanthocarpa 93

Tabela 23. DL50 do extrato EHA de C. xanthocarpa em Artêmias. .93

Tabela 24. Avaliação da atividade antimicrobiana do extrato EHA de C. xanthocarpa .94 
Tabela 25. Determinação da Concentração Mínima Inibitória de ampicilina sódica, nistatina e do extrato EHA de C. xanthocarpa. .95

Tabela 26. Média do número de ulcerações do nível I, produzidas pela indução com ácido clorídrico $0,3 \mathrm{M}$ em etanol, nos grupos de animais tratados por via oral com $400 \mathrm{mg} / \mathrm{kg}$ do extrato EHA de C. xanthocarpa, misoprostol $(0,1 \mathrm{mg} / \mathrm{kg})$ e controle .97

Tabela 27. Média do número de ulcerações do nível II, produzidas pela indução com ácido clorídrico 0,3 $\mathrm{M}$ em etanol, nos grupos de animais tratados por via oral com $400 \mathrm{mg} / \mathrm{kg}$ do extrato EHA de C. xanthocarpa, misoprostol $(0,1 \mathrm{mg} / \mathrm{kg})$ e controle $(1 \mathrm{~mL} / \mathrm{kg})$. .98

Tabela 28. Média do número de ulcerações do nível III, produzidas pela indução com ácido clorídrico 0,3 M em etanol, nos grupos de animais tratados por via oral com $400 \mathrm{mg} / \mathrm{kg}$ do extrato EHA de C. xanthocarpa, misoprostol $(0,1 \mathrm{mg} / \mathrm{kg})$ e controle $(1 \mathrm{~mL} / \mathrm{kg})$. .99

Tabela 29. Análise cromatográfica em camada delgada (Sistema 6) de substâncias antioxidantes da droga vegetal e do extrato EHA de C. xanthocarpa. e das soluções metanólicas a $0,05 \%$ das substâncias químicas de referência (SQR) quercetina, rutina, apigenina, crisina e ácido clorogênico, como revelador o reativo $\beta$-caroteno em solução 1:1 de clorofórmio e etanol. 101

Tabela 30. Análise cromatográfica em camada delgada (sistema 7) de substâncias antioxidantes da droga vegetal e do extrato EHA de C. xanthocarpa. e das soluções metanólicas a $0,05 \%$ das substâncias químicas (SQR) rutina e quercetina 102 
Tabela 31. Análise cromatográfica em camada delgada (sistema 8) de substâncias antioxidantes da droga e do extrato EHA de C. xanthocarpa. e da solução metanólica a $0,05 \%$ da substância química de referência (SQR) quercetina, como revelador o reativo $\beta$-caroteno em solução 1:1 de clorofórmio e etanol. 103

Tabela 32. Capacidade antioxidante (CAOx\%) do extrato EHA de C. xanthocarpa, na lipoperoxidação espontânea do homogenato de cérebro de rato 104

Tabela 33. Valores de "Lag-time" obtidos segundo ESTEBAUER e cols. (1992), expressando a Cinética de oxidação de LDL induzida por sulfato de cobre, a 234 nm, na presença de concentrações crescentes de extrato EHA de C. xanthocarpa.

Tabela 34. Valores de "Peak-time" obtidos segundo ESTEBAUER e cols. (1992), expressando a Cinética de oxidação de LDL induzida por sulfato de cobre, a 234 $\mathrm{nm}$, na presença de concentrações crescentes de extrato EHA de $C$. 


\section{INDICE DE FIGURAS}

Página

Figura 1. Campomanesia xanthocarpa Berg. Aspecto geral da planta....57

Figura 2. C. xanthocarpa Berg. Detalhe do caule .58

Figura 3. C. xanthocarpa Berg. Detalhe do caule com ritidoma esfoliativo. .58

Figura 4. C. xanthocarpa Berg. Ramos floridos .58

Figura 5. C. xanthocarpa Berg. Ramos frutificados .58

Figura 6. C. xanthocarpa Berg. Droga vegetal constituída de folhas e droga pulverizada.. .59

Figura 7. C. xanthocarpa Berg. Aspecto geral da droga. 59

Figuras 8 a 11. C. xanthocarpa Berg. Seções transversais da lâmina foliar evidenciando mesofilo dorsiventral, cavidade secretora, idioblasto e cristais prismáticos. 60

Figuras 12-13. C. xanthocarpa Berg. Seções transversais da lâmina foliar evidenciando mesofilo dorsiventral, epiderme adaxial, parênquima paliçádico, parênquima lacunoso, epiderme abaxial camada subepidérmica, bainha de extensão, cristal prismático e idioblasto. 61

Figuras 14-18. C. xanthocarpa Berg. Fig. 14. Vista frontal da face abaxial 
(200x): cs- cavidade secretora. Fig. 15-18. detalhe da região comissural das células que recobrem as cavidades secretoras, estômatos anomocíticos, ce- células epidérmicas (400x). 62

Figuras 19-21. C. xanthocarpa Berg. Fig.19. Aspecto geral da seção transversal da nervura mediana, evidenciando o feixe vascular. Fig. 20. vista frontal da face abaxial evidenciando tricomas tectores (400x). Fig. 21. detalhes da nervura mediana (400x) 63

Figuras 22-23. C. xanthocarpa Berg. Seções transversais da nervura mediana. Fig. 22. detalhe evidenciando o feixe vascular (200x). Fig. 23. detalhe destacando uma drusa 64

Figuras 24-25. C. xanthocarpa Berg. Seções transversais da nervura mediana. Fig. 24. destaque aos tricomas tectores (200x). Fig. 25. detalhe da cavidade secretora (400x). .65

Figuras 26-27. C. xanthocarpa Berg. Seções transversais da nervura mediana. Fig. 26. detalhe evidenciando cristais prismáticos no floema (400x). Fig. 27. destaque às cavidades secretoras junto à epiderme, cristais prismáticos e drusas no parênquima fundamental (200x)..... 66

Figura 28. C. xanthocarpa. Berg. Seção transversal do pecíolo evidenciando cavidade secretora junto à epiderme (200x).

Figura 29. C. xanthocarpa Berg. Seção transversal do pecíolo, destacando o feixe vascular bicolateral e drusas (400x). 68

Figura. 30. Curva padrão da substância química de referência pirogalol, linearidade da curva, limite de confiança superior e inferior 
Figura 31. Cromatograma em fase gasosa do óleo essencial, obtido por hidrodestilação das folhas de $C$. xanthocarpa

Figura 32. Consumo de água dos camundongos fêmea controle e tratados com extrato EHA de C. xanthocarpa, na dose de $5 \mathrm{~g} / \mathrm{kg}$ peso de animal no ensaio de toxicidade aguda 81

Figura 33. Consumo de ração dos camundongos fêmea controle e tratadas com extrato EHA de C. xanthocarpa, na dose de $5 \mathrm{~g} / \mathrm{kg}$ peso de animal no ensaio de toxicidade aguda 82

Figura 34. Massa média dos camundongos fêmea controle e tratados com extrato EHA de C. xanthocarpa, na dose de $5 \mathrm{~g} / \mathrm{kg}$ peso de animal no ensaio de toxicidade aguda .83

Figura 35. Massa relativa dos rins dos camundongos fêmea controle e tratados com extrato EHA de C. xanthocarpa, na dose de $5 \mathrm{~g} / \mathrm{kg}$ peso de animal no ensaio de toxicidade aguda. 84

Figura 36. Massa relativa de fígados dos camundongos fêmea controle e tratados com extrato EHA de C. xanthocarpa, na dose de $5 \mathrm{~g} / \mathrm{kg}$ peso de animal no ensaio de toxicidade aguda. 85

Figura 37. Massa relativa de coração e pulmões dos camundongos fêmea controle e tratados com extrato EHA de C. xanthocarpa, na dose de $5 \mathrm{~g} / \mathrm{kg}$ peso de animal no ensaio de toxicidade aguda. 86

Figura 38. Consumo de água dos camundongos macho controle $e$ tratados com extrato EHA de C. xanthocarpa, na dose de $5 \mathrm{~g} / \mathrm{kg}$ peso de animal no ensaio de toxicidade aguda. 
Figura 39. Consumo de ração dos camundongos macho controle e tratados com extrato EHA de C. xanthocarpa, na dose de $5 \mathrm{~g} / \mathrm{kg}$ peso de animal no ensaio de toxicidade aguda

Figura 40. Massa corpórea média dos camundongos macho controle e tratados com extrato EHA de C. xanthocarpa, na dose de $5 \mathrm{~g} / \mathrm{kg}$ peso de animal no ensaio de toxicidade aguda. 89

Figura 41. Massa relativa dos rins dos camundongos machos controle e tratados com extrato EHA de C. xanthocarpa, na dose de $5 \mathrm{~g} / \mathrm{kg}$ peso de animal no ensaio de toxicidade aguda 90

Figura 42. Massa relativa dos fígados dos camundongos macho controle e tratados com extrato EHA de C. xanthocarpa, na dose de $5 \mathrm{~g} / \mathrm{kg}$ peso de animal no ensaio de toxicidade aguda

Figura 43. Massa relativa dos corações e pulmões dos camundongos macho controle e tratados com extrato EHA de C. xanthocarpa, na dose de $5 \mathrm{~g} / \mathrm{kg}$ peso de animal no ensaio de toxicidade aguda

Figura 44. Ensaio de atividade antiúlcera induzida por solução de ácido clorídrico em etanol a $60 \%$, nos grupo controle e tratado com extrato EHA de C. xanthocarpa e o padrão misoprostol. 100

Figura 45. Médias do número de ulcerações do nivel I, no grupo de animais controle e tratados por via oral com extrato EHA de $C$. xanthocarpa e o padrão misoprostol.

Figura 46. Médias do número de ulcerações do nível II, no grupo de animais controle e tratados porvia oral com extrato EHA de $C$. xanthocarpa e o padrão misoprostol. 98 
Figura 47. Médias do número de ulcerações do nível III, no grupo de Animais controle e tratados or via oral com extrato EHA de C. xanthocarpa e o padrão misoprostol

Figura 48. Capacidade antioxidante do extrato EHA de C. xanthocarpa, determinação da linearidade, regressão linear e a concentração necessária para atingir $50 \%$ da capacidade antioxidante (IC 50). 105

Figura 49. Oxidação de lipoproteínas de baixa densidade (LDL), induzida por sulfato de cobre, monitorada a $234 \mathrm{~nm}$ durante 200 minutos. As curvas $n^{\circ} 1,2,3,4,5$ e 6 apresentam os tempos de iniciação da formação de dienos conjugados nas concentrações: $0 ; 0,150 ; 0,312 ; 0,625 ; 1,250$ e $2,500 \mu \mathrm{g} / \mathrm{mL}$ de extrato EHA de C. xanthocarpa, no meio de reação......106

Figura 50. Oxidação de LDL induzida por sulfato de cobre na ausência de extrato de EHA de C. xanthocarpa. Determinação de "Lag-time" e "Peaktime", segundo Esterbauer e cols. (1992). 107

Figura 51. Oxidação de LDL induzida por sulfato de cobre na presença de $0,150 \mu \mathrm{g} / \mathrm{mL}$ de extrato de EHA de C. xanthocarpa. Determinação de "Lag-time" e "Peak-time", segundo Esterbauer e cols. (1992). 108

Figura 52. Oxidação de LDL induzida por sulfato de cobre na presença de $0,312 \mu \mathrm{g} / \mathrm{mL}$ de extrato de EHA de C. xanthocarpa. Determinação de "Lag-time" e "Peak-time", segundo Esterbauer e cols. (1992). 109

Figura 53. Oxidação de LDL induzida por sulfato de cobre na presença de $0,625 \mu \mathrm{g} / \mathrm{mL}$ de extrato de EHA de $C$. xanthocarpa. Determinação de "Lag-time" e "Peak-time", segundo Esterbauer e cols. (1992). 
Figura 54. Oxidação de LDL induzida por sulfato de cobre na presença de $1,250 \mu \mathrm{g} / \mathrm{mL}$ de extrato de EHA de C. xanthocarpa. Determinação de "Lag-time" e "Peak-time", segundo Esterbauer e cols. (1992). 111

Figura 55. Valores de "Lag-time" na presença de concentrações crescentes do extrato EHA de C. xanthocarpa.

Figura 56. Valores de "Peak-time" na presença de concentrações crescentes do extrato EHA de C. xanthocarpa. 


\section{INTRODUÇÃO}

Todas as grandes civilizações, incluindo a sumariana, babilônica, caldense, chinesa, egípcia, grega, indiana, persa e romana, empregaram plantas como primeira fonte de medicamentos, assim como, na alimentação como matéria prima para escrita, vestuário e cosméticos, dentre outras finalidades. Os conhecimentos de dessas civilizações foram difundidos pelas migrações culturais que ocorreram através dos séculos (CORDELL, 1993).

Em 1524, quando Paracelsus escreveu "Archidoxa" de um "Arcanum", fez referência que o segredo do tratamento de doenças era a necessidade da descoberta dos componentes ativos, seja dos vegetais, como dos animais ou minerais (PATCHTER, 1951; CORDELL, 2000).

A pesquisa de substâncias ativas começou ao redor de 1870 com o trabalho de SCHEELE sobre ácidos orgânicos de plantas (SNEARDER, 1985). Em meados do século 19 , os compostos bioativos foram surgindo, com a pesquisa de plantas medicinais conhecidas. Estes estudos levaram à descoberta de alcalóides como morfina, atropina, papaverina e codeína (CORDELL, 1993).

FARNSWORTH e cols., em 1985, registraram 119 compostos isolados de 90 plantas que eram usadas na medicina tradicional. CORDELL e cols. (1997) analisaram no periodo de 1983 a 1994, as drogas que foram aprovadas pelo Food and Drug Administration (FDA). De 520 fármacos, 157 foram obtidos de produtos naturais ou seus derivados. Nesse mesmo período, $61 \%$ dos agentes anticancerígenos aprovados eram de origem natural ou seus derivados.

No fim do século 20 , a prática do uso de plantas medicinais foi divulgada através do mundo, devido, em parte, ao reconhecimento dos valores dos sistemas de medicina tradicional, particularmente as de origem asiática, e a inclusão das plantas medicinais em farmacopéias por terem significativo poder de cura, tanto no estado natural ou como fonte de novos fármacos (LEWIS, 2001). 
No Brasil, a biodiversidade existente é estimada em $20 \%$ do globo terrestre, existindo uma relação direta entre a diversidade biológica e estruturas quimicas biossintetizadas. Estes dados incrementam a possibilidade de serem descobertas substâncias bioativas constituindo um imenso potencial farmacológico (BRITO, 1996).

A disponibilidade de informações sobre estudos químicos e farmacológicos da flora brasileira é pequena quando comparada a dados botânicos

A familia Myrtaceae é muito bem representada no Brasil, sobretudo na região sudeste, apresentando forte expressividade na composição da Floresta Pluvial Atlântica (BARROSO e cols., 1991). O gênero Campomanesia destaca-se dos demais membros da familia pelas características dos seus frutos e sementes e pelo padrão de venação foliar (LANDRUM, 1987)

Campomanesia xanthocarpa objeto deste estudo, é conhecida popularmente como gabiroba, que significa árvore de casca amarga. Ocorre do Espírito Santo ao Paraguai e Nordeste da Argentina (CARRARA, 1997). Seu valor medicinal é reconhecido no combate a várias enfermidades tais como disenteria, febre, escorbuto, cistite e uretrite (CRAVO, 1994; ALICE e cols., 1995). Embora seja empregada na medicina popular, não se encontram na literatura estudos de atividades farmacológicas que sustentem sua utilização.

O presente trabalho pretende contribuir no conhecimento de algumas das atividades farmacológicas do extrato preparado com as folhas desta espécie, bem como na caracterização da folha como droga vegetal. 


\section{GENERALIDADES}

\subsection{Aspectos botânicos}

\subsubsection{A familia Myrtaceae}

A família Myrtaceae Jussieu compreende aproximadamente 3.500 espécies, subordinadas a 100 gêneros. Seus representantes apresentam porte arbustivo ou arbóreo (BARROSO, 1991).

As folhas são simples, coriáceas, inteiras, opostas ou às vezes altemas, sem ou com estípulas muito pequenas. As pontoações devem-se à presença de glândulas oleíferas. A nervação é perinérvea, com freqüente formação de nervura marginal (LEGRAND e KLEIN, 1977, JOLY, 1991).

As flores, em geral, são brancas ou vermelhas, efêmeras, hermafroditas, de simetria radial, normalmente pentâmeras, mono ou diclamídeas, muitas vezes com um receptáculo bem desenvolvido. $O$ androceu é polistêmone e dialistêmone, com estames desprovidos de anteras com bases fixas. Tem-se sugerido que o número de estames tem aumentado nas mirtáceas devido à polinização por pássaros e borboletas. O ovário mostra-se súpero a semi-ínfero até ínfero, variando de uni a multilocular. Na maioria das espécies encontram-se 2 a 4 lóculos, raras vezes até 5 em Psidium; em Campomanesia e Britoa de 5 a 8, ou mais lóculos. A placentação axilar, geralmente é central, raramente basal (Myrciaria, Siphoneugenia) ou com dois placentários sobressaindo desde o centro (Psidium). O estigma é indiviso. As sementes freqüentemente mostram poliembrionia; algumas vezes, são aladas (LEGRAND e KLEIN,1978).

A anatomia do caule de Myrtaceae caracteriza-se pelo floema intraxilemático e pontoações areoladas guarnecidas. As folhas são hipoestomáticas, providas de estômatos anomocíticos e paracíticos. Taninos e cristais de oxalato de cálcio são freqüentes (METCALFE e CHALK, 1950).

A família é dividida em duas subfamílias (GEMTCHÜJNICOV, 1976; LEGRAND e KLEIN, 1978) a saber. 
- Leptospermoideae, cujos representantes apresentam frutos secos do tipo cápsula, aquênio e pixídio. Seu centro de dispersão é representado por Austrália e Polinésia.

- Myrtoideae, cujos representantes apresentam frutos camosos, geralmente baciformes.

A subfamília Myrtoideae, bem representada na América tropical, subtropical e até na temperada, é dividida em tribos por MELCHIOR (1964). As mirtáceas do Brasil foram tratadas na monografia de Berg (1957) que as classifica em uma única tribo, a Myrteae com 5 subtribos tendo como base os tipos de embrião. Segundo LANDRUM e KAWASAKY (1997) a tribo Myrteae inclui todas as mirtáceas com ovário infero e frutos carnosos, abrangendo cerca de 70 gêneros. As subtribos nativas no Brasil, de acordo com LANDRUM e KAWASAKY (1997), são:

4 Subtribo Myrciinae, que inclui os gêneros Myrcia, Gomidesia, Marlierea, Calyptrantes e Myrceugenia;

- Subtribo Eugeniinae, dentre os gêneros incluídos, os principais são: Hexachlamys, Eugenia, Plinia, Siphoneugena, Myrciania, Calycorectes, Myrcianthes e Neomitranthes.

4 Subtribo Myrtinae, dentre os gêneros incluidos, os principais são: Acca, Accara, Mosiera, Blepharocalyx, Pimenta, Myrrhinium, Calycolpus, Campomanesia, Psidiun e Ugni.

\subsubsection{O gênero Campomanesia}

O gênero Campomanesia, a que pertence a espécie em estudo, está incluída na subfamília Myrtoideae, tribo Myrteae, subtribo Myrtinae (CRONQUIST, 1984, CRONQUIST, 1988, LANDRUN, 1986).

O gênero Campomanesia foi classificado em 1794 por Ruiz e Pavón, em homenagem ao conde Pedro Rodriguez de Campomanés, com base em $C$. lineatifolia. Na obra "Flora Brasiliensis" foram descritas 51 espécies de Campomanesia. 
As espécies de Campomanesia possuem importância econômica diversificada. Seus frutos comestiveis são consumidos por várias espécies de pássaros e mamíferos, além do uso para a produção de doces caseiros, sorvetes, aguardentes, licores e refrescos. Suas flores são indicadas como melíferas. Sua madeira é usada na produção de instrumentos musicais, cabos de ferramentas, instrumentos agrícolas, lenha, carvão e cercas. Algumas espécies são cultivadas para o uso no paisagismo. Seu valor medicinal é reconhecido no combate a várias enfermidades, dentre elas, disenteria, febre, diarréia, escorbuto, cistite e uretrite. (GEMTCHUJNICOV, 1976, CRAVO, 1994, ALICE, e cols. 1995).

\subsubsection{Campomanesia xanthocarpa Berg.}

Campomanesia xanthocarpa, espécie conhecida vulgarmente por gabiroba, guabiroba, gaubirobeira e guabirobeira do mato, ocorre do Espírito Santo ao Rio Grande do Sul, sendo citada também no Paraguai e nordeste da Argentina (CORREA, 1952, LEGRAND e KLEIN, 1978, MATTOS, 1983).

A espécie é um arbusto, arvoreta ou árvore de 10 a $20 \mathrm{~m}$ de altura e até $60 \mathrm{~cm}$ de diâmetro na base. O ritidoma é escamoso, acinzentado, com estrias longitudinais. Os ramos novos são glabros. As folhas são opostas, pecioladas, variando de lanceoladas, elípticas a ovadas, sempre inteiras. O contorno foliar e o tamanho são variáveis; medindo geralmente de 3 a $8 \mathrm{~cm}$ de comprimento por 2,5 a $4,5 \mathrm{~cm}$ de largura. Apresentam ápice agudo a acuminado; base aguda a obtusa. Os peciolos canaliculados, medem de 6-20 mm de comprimento por 1$1,2 \mathrm{~mm}$ de espessura. A lâmina foliar é papirácea e de cor verde (CORREA, 1952, LEGRAND, 1957, MATTOS, 1983, MATTOS, 1984).

C. xanthocarpa Berg apresenta a seguinte sinonimia científica (Index Kewensis):

4 Psidium punctulatum auct. non DC.,Miquel, Linnaea 22: 533. 1849. Regnell I. 126.

4 Psidiun eugenoides auct. non Cambess, Miquel, Linnaea 22:533.1849. Regnell I.126b, 126c. 
\Campomanesia malifolia O. Berg, in Martius, FI Bras. 14(1):452.1857.

-Campomanesia crenata O. Berg inı Martius, FI. Bras. 14(1):456. 1857.

\Campomanesia rhombea O. Berg, in Martius, FL. Bras. 14(1):453. 1857.

¿ Campomanesia rhombea [var.] $\beta$ parvifolia O. Berg.

4 Campomanesia hombea [var.] $\beta$ parvifolia O. Berg, in Martius, Fl. Bras. 14(1):453.1857.

4 Campomanesia mombea [var.] a grandifolia O. Berg, in Martius, Fl. Bras. 14(1):453.1857.

\Campomanesia xanthocarpa var. malifolia (o. Berg) Legrand, in Legrand \& Klein, Fl. liustr. Catarinense. [Mirt]: 602. 1977.

- Campomanesia rhombea var. kleinii D. Legrand, in Legrand \& Klein, Fl. liust. Catar. [MIRT]: 612. 1977.)

४ampomanesia dusenii Kausel, Lilloa 33 (6): 100, 1971.

\subsection{Aspectos químicos e biológicos de Myrtaceae}

Em razão do elevado número de espécies na familia, a revisão de literatura na parte referente aos componentes químicos e estudos biológicos foi restrita a representantes pertencentes a gêneros encontrados no Brasil (tabela 1). A seleção dos gêneros seguiu a sugerida por LANDRUN e KAWASAKI (1997). 


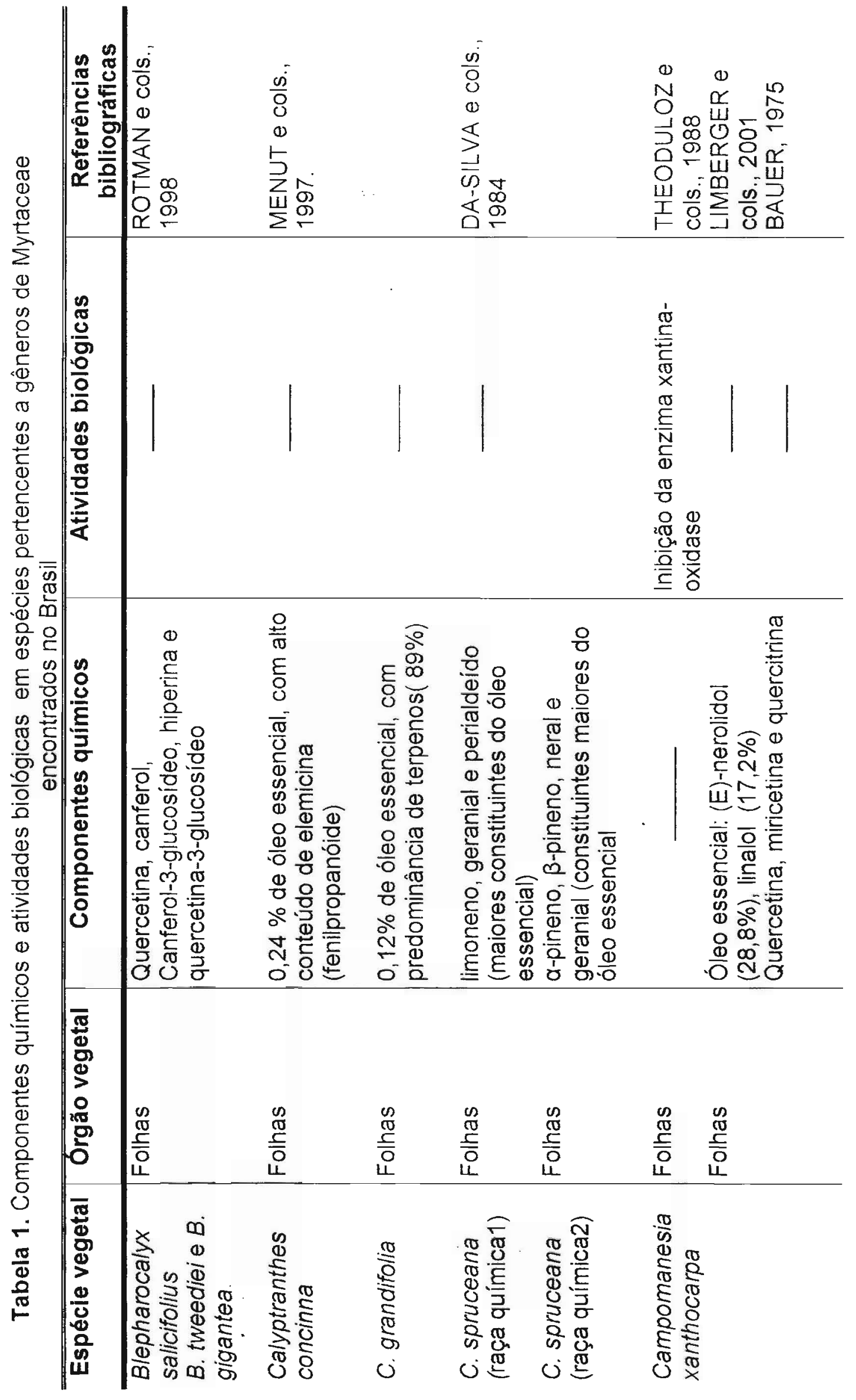




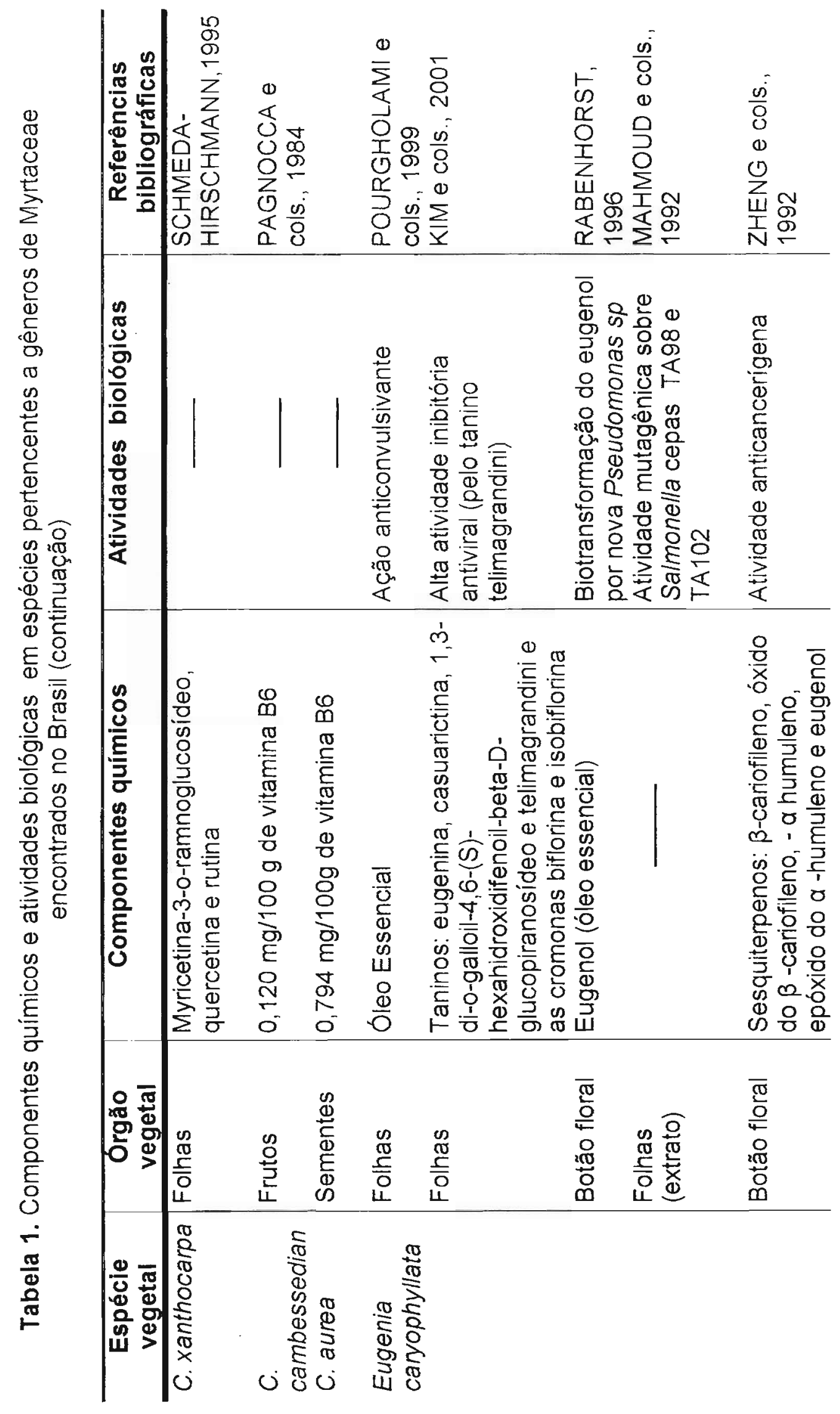




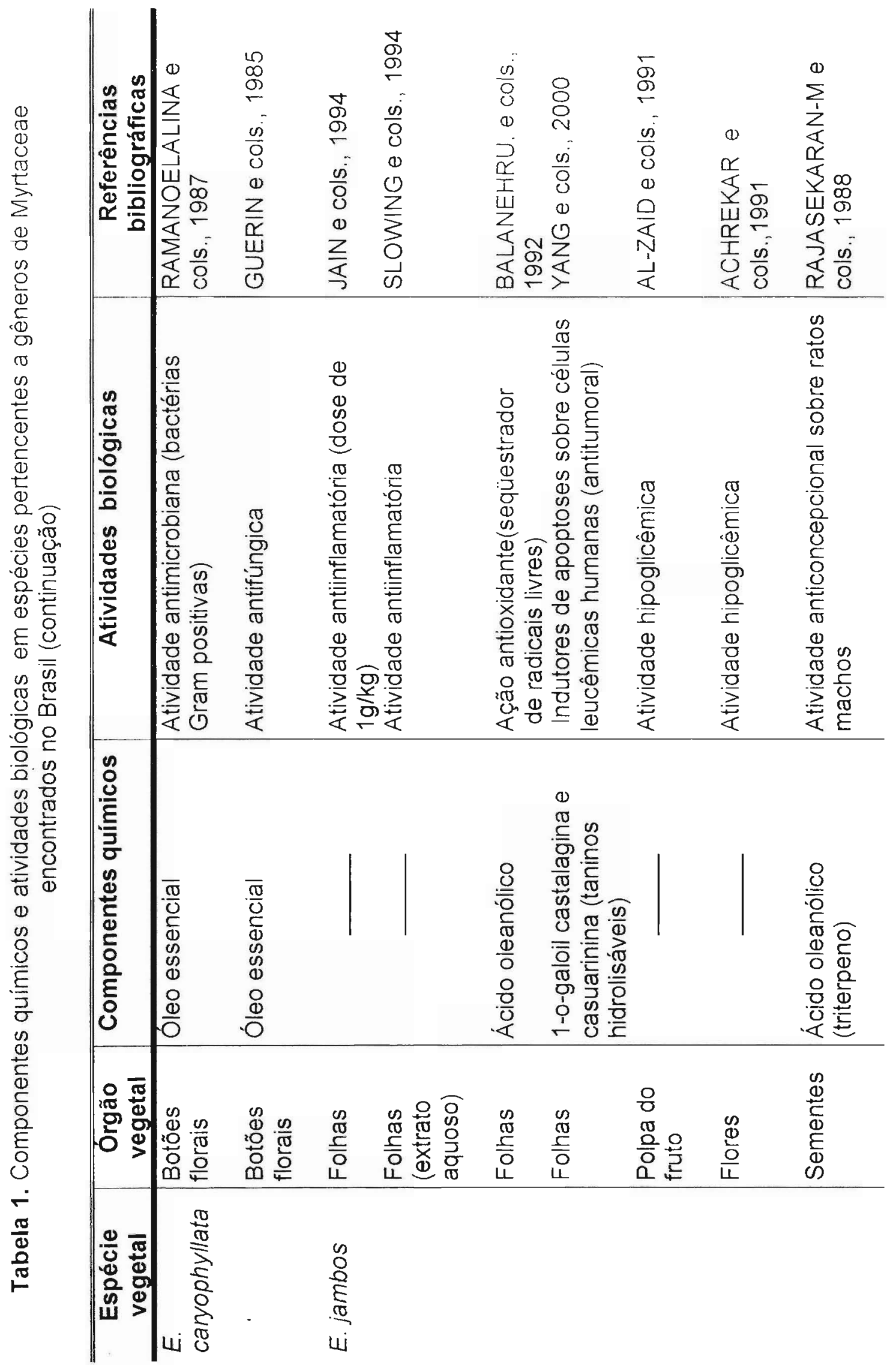




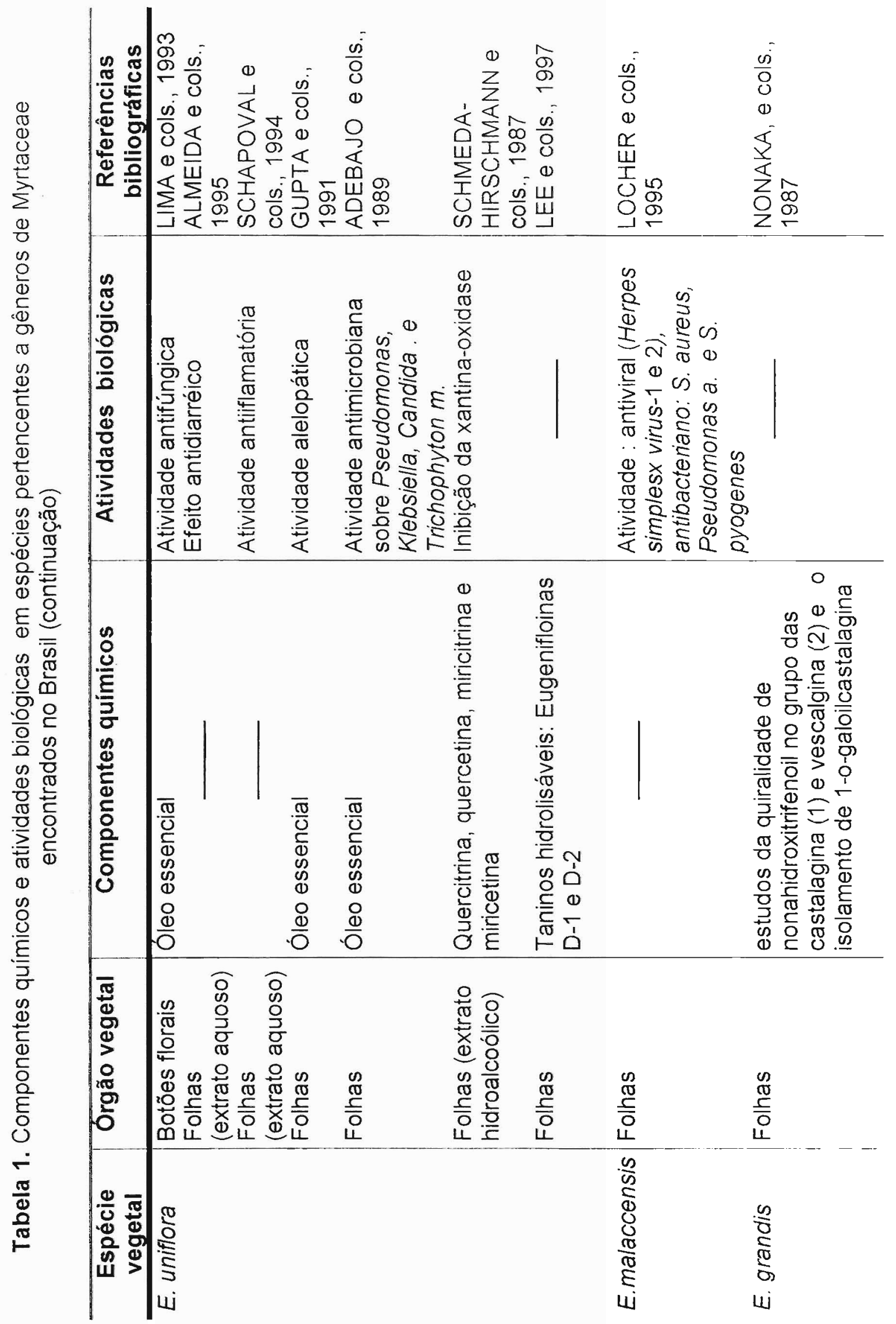




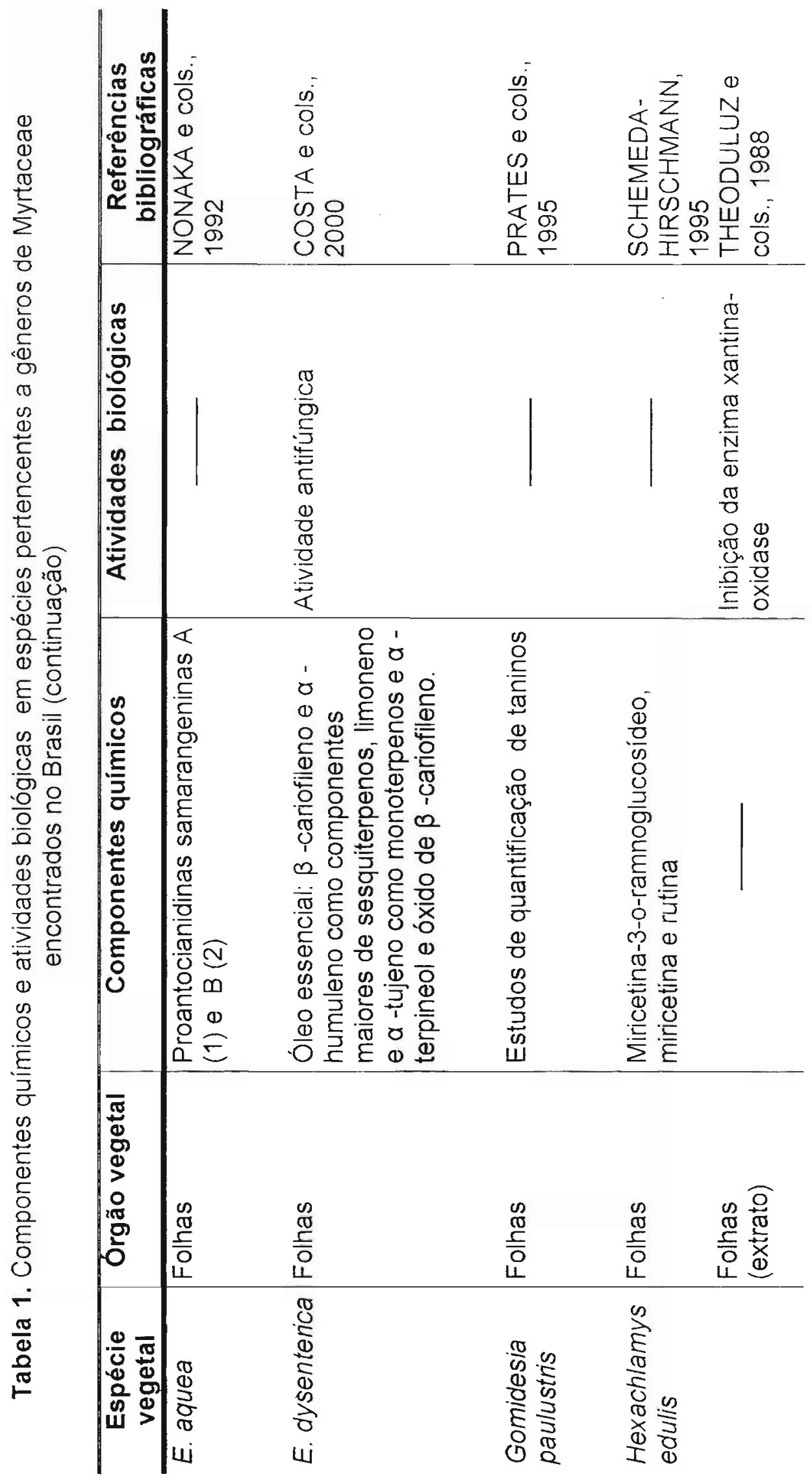




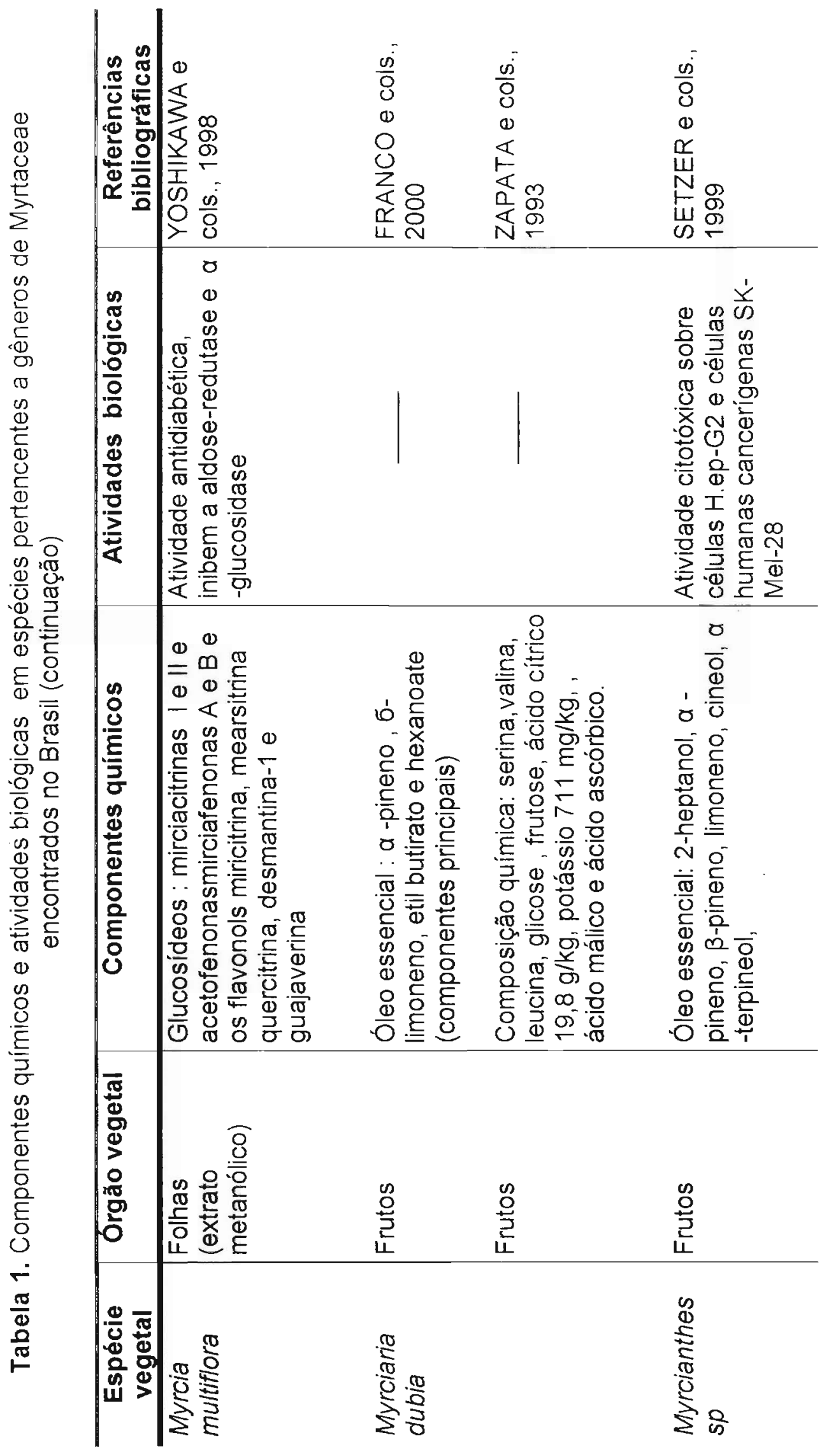




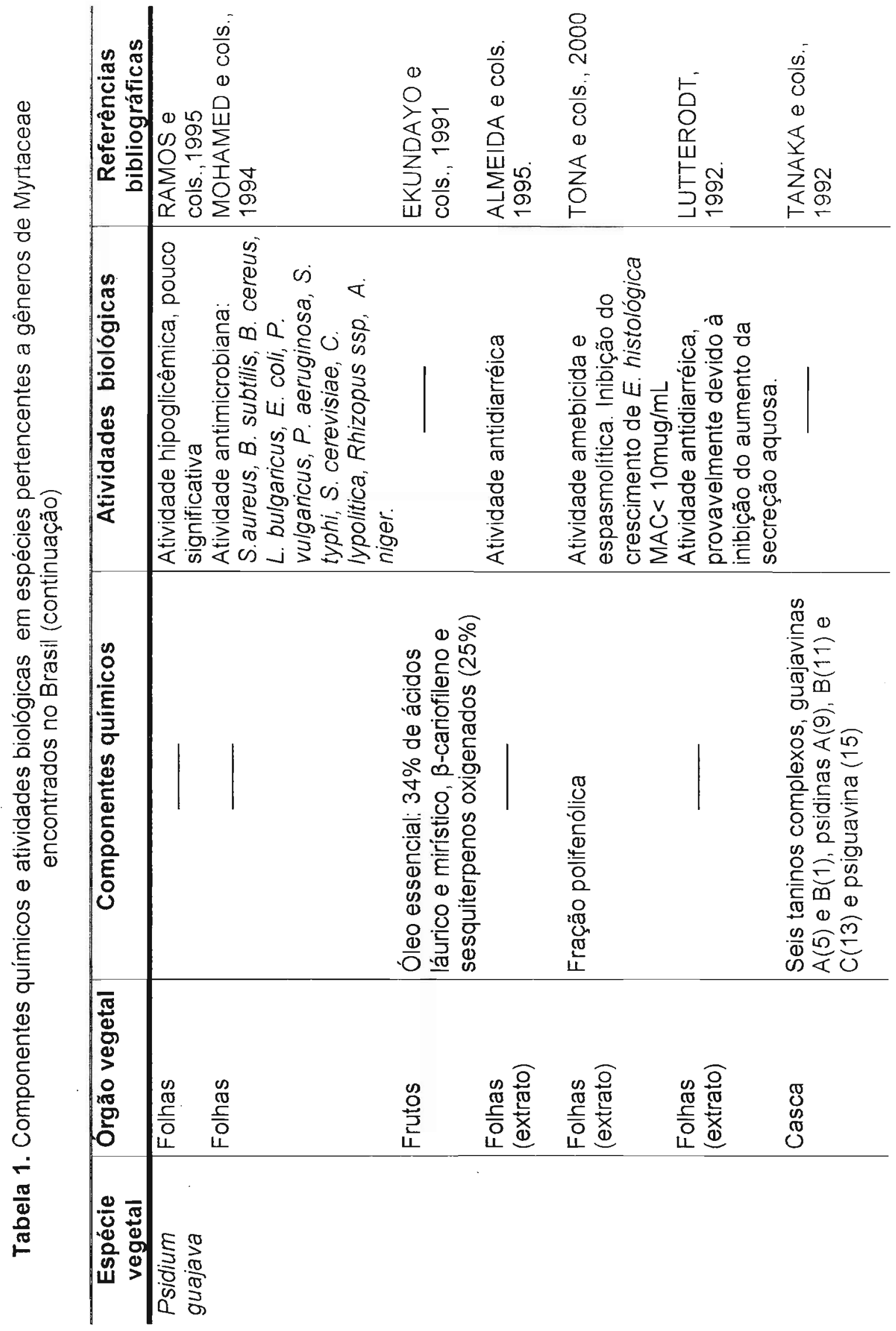




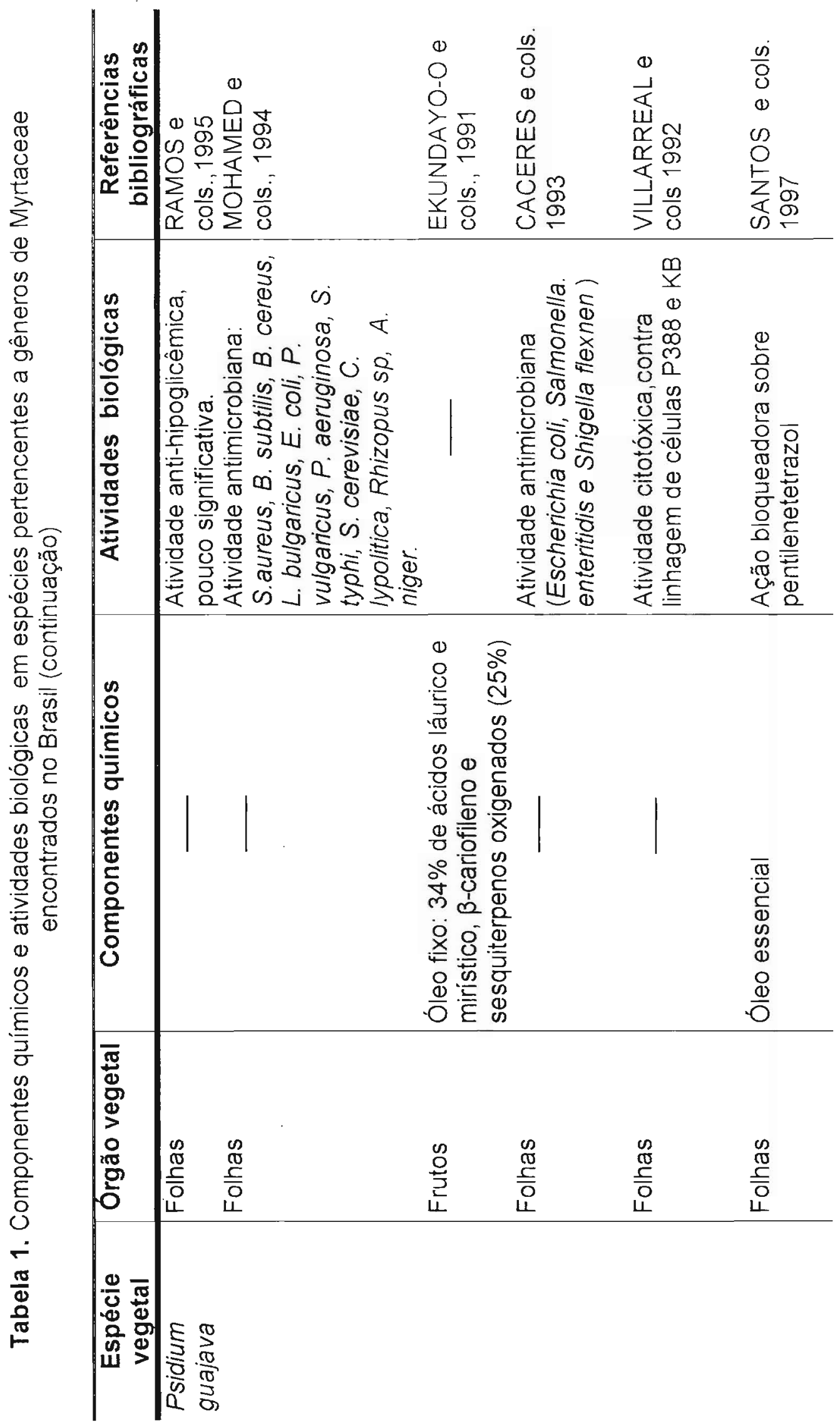




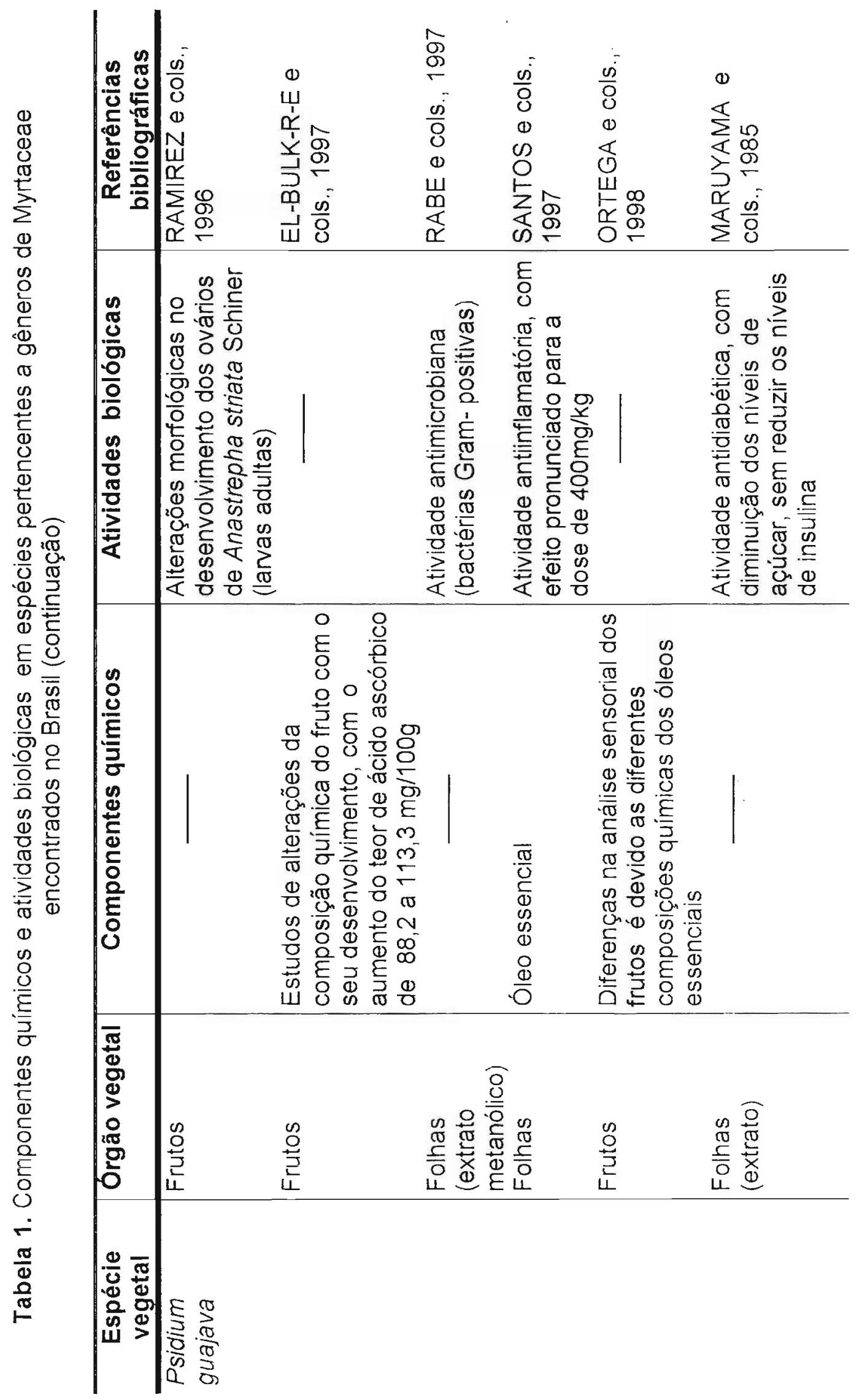




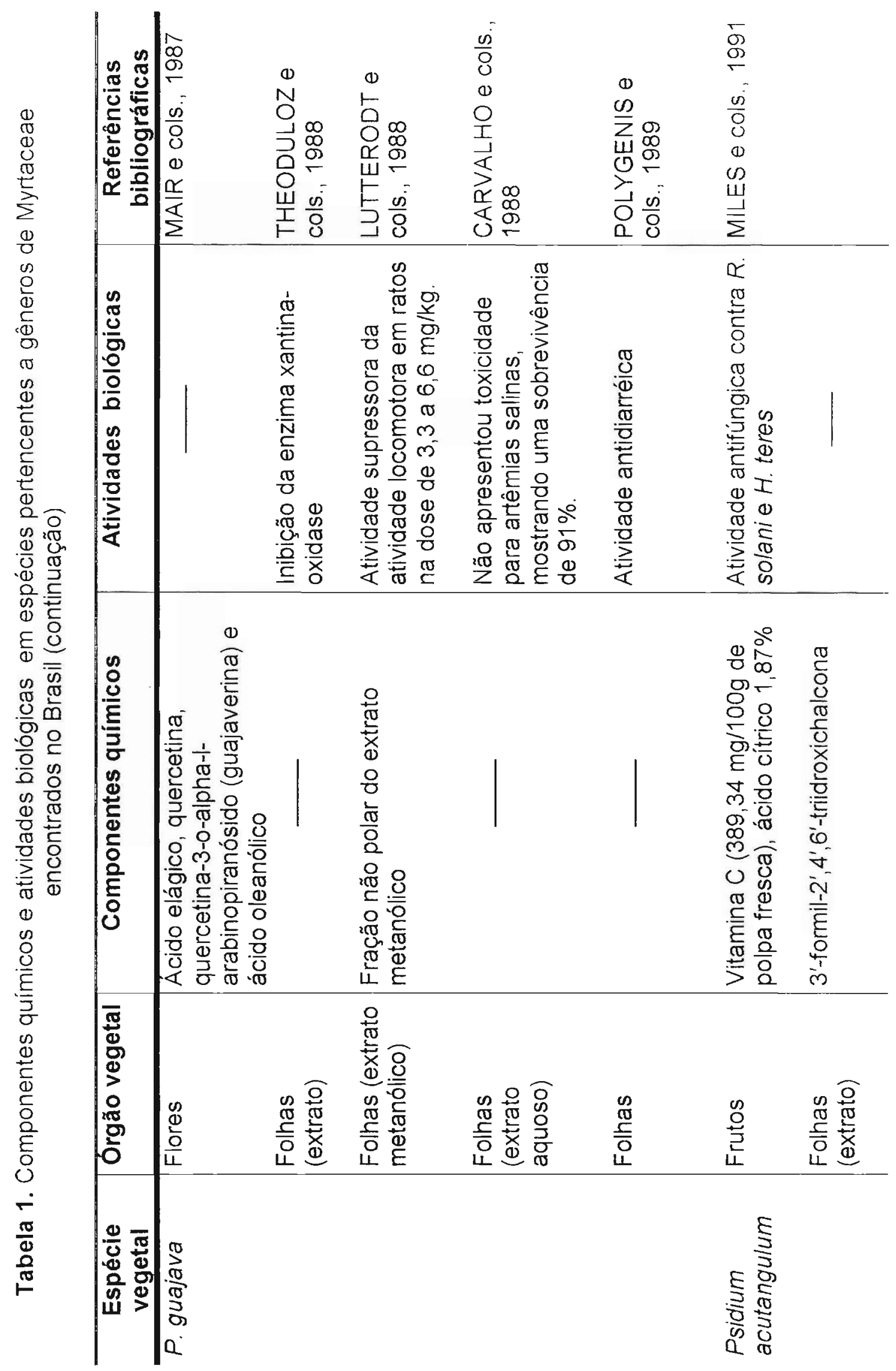




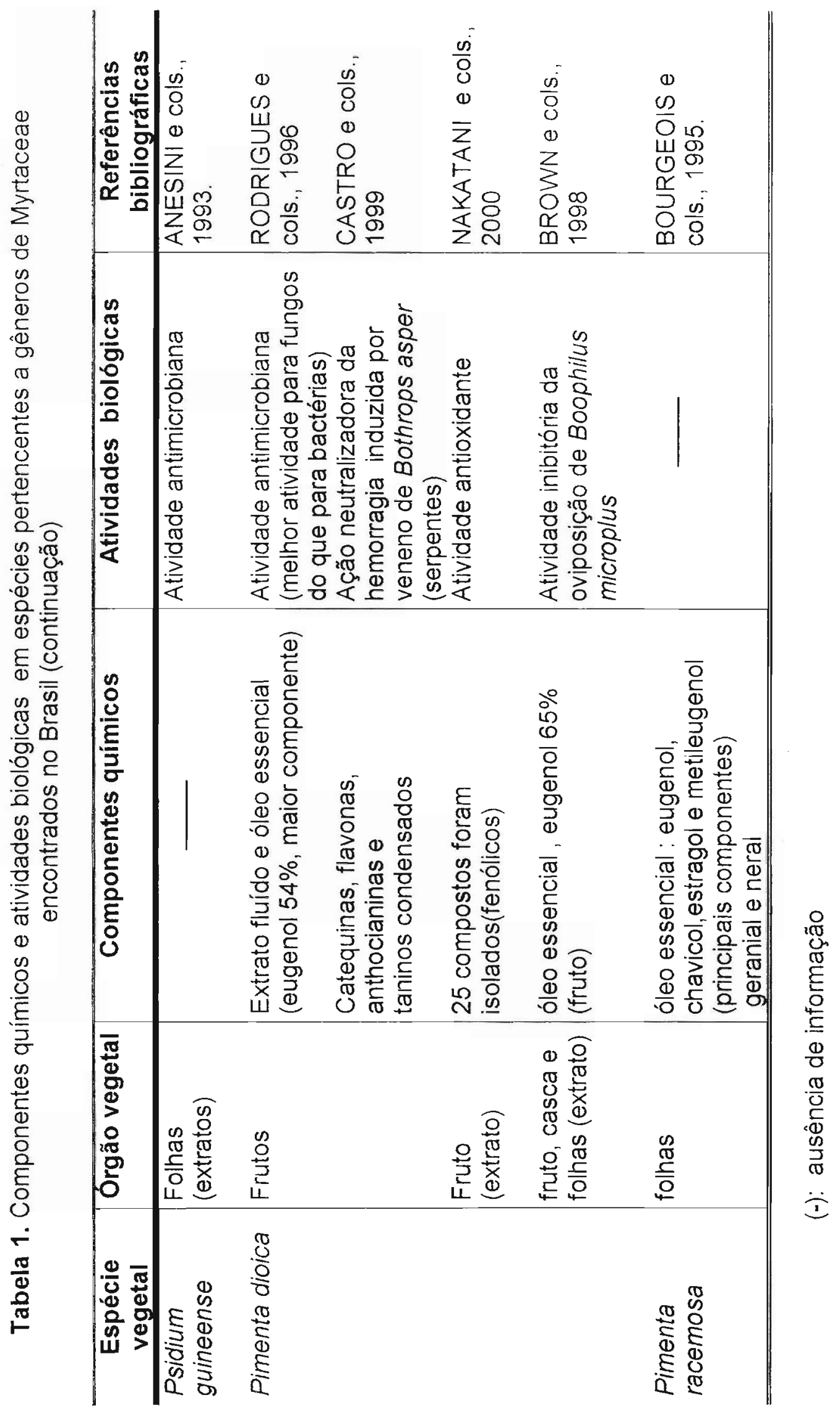




\subsection{Tópicos sobre atividade antiúlcera}

Úlceras pépticas ocorrem quando o mecanismo de defesa da mucosa falha contra os agentes agressores. O acréscimo de secreção ácida (GUPTA e cols., 1980) e outros fatores como o decréscimo da resistência e infecção bacteriana tem sido implicados nesta patogênese (PEARSON e cols., 1980).

Durante vários séculos a neutralização do suco gástrico com antiácidos era a única forma de tratar as úlceras.

Estudos do controle fisiológico da secreção ácida, demonstraram que agentes anticolinérgicos poderiam moderar esse processo. $O$ desenvolvimento, por BLACK e cols. (1993), de antagonistas que agem sobre receptores $\mathrm{H}_{2}-$ histaminérgicos, proporcionaram uma classe mais específica de inibidores de secreção ácida (BRUNTON, 1996).

O tratamento de úlceras gástricas pode ser direcionado para a redução dos agentes agressores ou promoção das defesas da mucosa estomacal e duodenal, através do uso de agentes citoprotetores.

As prostaglandinas tem um papel importante na integridade da mucosa gástrica estimulando a secreção de muco e bicarbonato por células epiteliais, contribuindo para o efeito citoprotetor desta mucosa (MIZUI, 1983). A importância do papel das prostaglandinas na citoproteção é manifestada pelo efeito ulcerogênico de drogas antiinflamatórias não esteroidais que inibem a síntese de prostaglandinas.

A propriedade citoprotetora da mucosa gástrica era considerada como específica das prostaglandinas. Estudos mais recentes tem demonstrado uma variedade de fármacos e compostos com propriedades citoprotetoras gástricas, os quais não apresentam semelhança estrutural com prostaglandinas (FERNANDEZ e cols., 1990).

O uso de antiácidos e antihistamínicos, entre outros, no tratamento de úlceras gástricas tem provocado arritmias, impotência e alterações hematológicas (ARIYPHI e cols., 1986). As várias reações adversas observadas tem levado à busca de agentes antiúlcera menos tóxicos e mais efetivos. 
Os extratos de plantas empregadas na medicina tradicional são uma fonte de novos fármacos com resultados promissores (GOEL e cols., 1990, AKHTAR e cols., 1995; AFIFI e cols., 1997, ALKOFAHI e cols., 1999; GONZALEZ e cols., 2000; GONZALEZ e cols., 2001; NAVARRETE e cols., 2002).

As familias que apresentaram representantes com atividade antiúlcera e que podem vir a contribuir com o arsenal terapêutico são: Azioaceae (AKHTAR e cols., 1995); Asteraceae (ALARCON de la LASTRA e cols., 1994); Bambusaceae (OTNI e cols, 1990); Caesalpinaceae (NOAMIESI e cols., 1994); Celastraceae (SOUZA e cols., 1991); Cistaceae (ATTAGUILE e cols., 1995); Combretaceae (DE PASQUALE e cols., 1995); Compositeae (BRUNE e cols., 1993); Crassulaceae (PAL e cols., 1991); Cucurbitaceae (TAKANO e cols. 1990); Fabaceae (NOAMESI e cols., 1994); Flacourtiaceae (BASILE e cols., 1990); Gentianaceae (RAFATULLAH e cols, 1995); Lauraceae (AKIRA e cols., 1986); Leguminosae (BACCHI e cols., 1995); Umbelliferae (HIRANO e cols., 1994); Zingiberaceae (RAFATULLAH e cols., 1995); Verbenaceae (PASCUAL e cols., 2001).

Dentre as diversas classes de compostos ensaiados para atividade antiúlcera, as flavonas, flavanóides, polissacarídeos e iridóides têm apresentado potente atividade citoprotetora em animais de laboratório (MOTILVA e cols., 1993, BEIL e cols., 1995, CATALANO e cols., 1995, YAMADA e cols, 1991)

\subsection{Tópicos sobre atividade antioxidante}

Radical livre é qualquer espécie química capaz de existir independentemente, que contenha um ou mais elétrons não pareados ocupando orbitais atômicos ou moleculares, com vida média muito curta. As espécies reativas de oxigênio (oxigênio singlete, ânion-radical superóxido, peróxido de hidrogênio, radical hidroxila, óxido nítrico e peroxinitrito) são geradas no citoplasma, mitocôndrias, retículo endoplasmático, membrana celular e núcleo de todas as células (LARSON, 1988, ABDALLA, 1996) 
Os radicais livres participam diretamente dos mecanismos fisiopatológicos, em um grande número de doenças que afetam o ser humano. As espécies radicalares atuam tanto nas reações inflamatórias, como também nos mecanismos de transdução de sinal, agindo como segundos mensageiros para manter diversas funções celulares (LARSON, 1988).

No organismo deve existir um equilíbrio entre a formação e a remoção de espécies radicalares, de modo que as reações e processos dependentes das mesmas possam ocorrer em nível adequado para a manutenção da fisiologia da célula. O desequilibrio entre a formação e a remoção dos radicais livres decorrente da redução dos antioxidantes endógenos, devido à menor formação ou maior consumo, ou do aumento da geração de espécies oxidantes gera um estado pro-oxidante (estresse oxidativo). Este estado favorece a ocorrência de lesões oxidativas em macromoléculas e estruturas celulares, podendo resultar na morte celular (ABDALLA, 1996).

Do ponto de vista biológico, antioxidantes são compostos que protegem sistemas biológicos contra os efeitos potencialmente danosos de processos ou reações que promovem a oxidação de macromoléculas ou estruturas celulares.

Reações radicalares no processo de peroxidação lipídica ocorrem em três etapas: iniciação, propagação e término (LARSON, 1988):

$$
\begin{aligned}
\text { Iniciação: } & \mathrm{LH} \rightarrow \mathrm{L} \cdot \\
\text { Propagação: } & \mathrm{L} \cdot+\mathrm{O}_{2} \rightarrow \mathrm{LOO} \cdot \\
& \mathrm{LOO} \cdot+\mathrm{LH} \rightarrow \mathrm{LOOH}+\mathrm{L} \cdot \\
& \mathrm{LOOH} \stackrel{\mathrm{Fet2}}{\mathrm{LO} \cdot+\mathrm{OH}^{-}} \\
& \mathrm{LOOH} \stackrel{\mathrm{Fe}+3}{\longrightarrow} \mathrm{LOO}+\mathrm{H}^{+} \\
\text {Término: } & \mathrm{LO} \cdot+\mathrm{LO} \cdot \mathrm{H}^{+} \longrightarrow{ }^{3} \mathrm{~L}=\mathrm{O}+\mathrm{LOH} \\
& \mathrm{LOO} \cdot+\mathrm{LOO} \cdot \mathrm{H}^{+} \rightarrow \mathrm{L}=\mathrm{O}+\mathrm{LOH}+{ }^{1} \mathrm{O}_{2}
\end{aligned}
$$


O sistema de defesa primário, constitui-se em primeira linha de defesa, formada por substâncias que impedem a geração de espécies reativas, ou sequestram-nas de forma a impedir sua interação com alvos celulares, ou seja bloqueiam a etapa de iniciação da cadeia radicalar. Neste item encontram-se: a) as enzimas antioxidantes, superóxido dismutase (SOD), glutationa peroxidase (GPX) e catalase; b) os quelantes e proteínas, como transferrina e a ceruloplasmina que transportam ferro e cobre, respectivamente; c) as substâncias não enzimáticas como urato, ascorbato, albumina, bilirrubina e carotenóides que seqüestram radicais superóxido e hidroxila, ou suprimem o oxigênio singlete (LARSON, 1988, ABDALLA, 1996).

O sistema secundário de defesa é formado geralmente por compostos fenólicos ou aminas aromáticas, que atuam bloqueando a etapa de propagação da cadeia radicalar, seqüestrando radicais intermediários (como peroxil ou alcoxil). Nesta classe estão os tocoferóis (vitamina $E$ ), tocotrienóis, flavonóides e vários antioxidantes sintéticos (LARSON, 1988, ABDALLA, 1996, RICE-EVANS, e cols., 1996, DUGAS e cols., 2000).

Uma terceira linha de defesa antioxidante é constituida pelos sistemas de reparo do DNA por proteases e fosfolipases, os quais agem removendo as lesões oxidativas do DNA, proteínas e lipideos, respectivamente (ABDALLA, 1996).

Polifenóis para serem definidos como antixidantes, devem satisfazer duas condições básicas: a) quando presentes, devem estar em concentrações baixas em relação ao substrato a ser oxidado, devem atrasar ou prevenir a autooxidação, e seqüestrar os radicais livres; b) o radical formado após a sequestração deve ser estabilizado através de ligações intramoleculares por pontes de hidrogênio (RICE-EVANS e cols., 1996). Compostos fenólicos caracterizam-se quimicamente por serem doadores de hidrogênio fenólico, fato que lhes confere a propriedade de seqüestradores de radicais livres (RICEEVANS e cols., 1996).

A maioria dos polifenóis constituintes de alimentos, são os flavonóis, assim como a quercetina e o canferol, flavonas como a luteolina, incluindo catequinas e antocianidinas como por exemplo a cianidina, malvidina e seus glicosideos, 
mostraram alta eficácia como antioxidantes tanto quanto a vitamina $C$, vitamina $E$ e $\beta$-caroteno (RICE-EVANS e cols., 1995).

TOURNAIRE e cols. (1993) desenvolveram metodologia para comparar a atividade antioxidante de treze flavonóides pela medida da fotoxidação de cada flavonóide. Eles concluíram que a presença da estrutura catecol no anel B é o fator que controla a eficiência da extinção do superóxido e a presença de 3hidroxila, determina a eficiência da reatividade química com o superóxido. A presença do grupo carbonila no $\mathrm{C}-4$, da dupla ligação entre $\mathrm{C}-2$ e C-3, e de dihidroxilas são fatores importantes para justificar a alta atividade antioxidante dos flavonóides e para a quelação de metais (HARBORNE, e cols., 2000).

Outra possivel contribuição para o mecanismo da atividade antioxidante dos flavonóides, é a habilidade de estabilizar membranas, através da diminuição de secreção de fluídos da membrana. Estudando esse fenômeno foram observados, uma série de flavonóides que estavam dentro da camada hidrofílica da membrana, provocando uma drástica diminuição de secreção de fluidos nesta região da membrana (ARORA e cols., 2000).

Flavonóides apresentam uma série de atividades biológicas complexas em torno de sua atividade antioxidante e de suas propriedades de modular enzimas ou receptores celulares. Dados de estudos toxicológicos são raros quando comparados com fármacos quimicamente definidos. Assim, alguns flavonóides tem ação mutagênica pelos seus efeitos prooxidantes, interfererindo com as vias metabólicas bioquímicas essenciais. Através de estudos intensivos de relação estrutura-atividade de flavonóides poderiam surgir fármacos para a prevenção e tratamento de várias doenças como câncer e problemas de coronánias (HODECK, e cols., 2002).

Aos carotenóides, flavonóides e taninos têm-se atribuído atividade antioxidante importante na prevenção de moléstias relacionadas ao aumento de radicais livres (CLINTON, 1998). 


\section{OBJETIVOS:}

Constitui objetivo desta dissertação contribuir para o melhor conhecimento da espécie vegetal Campomanesia xanthocarpa Berg., especialmente as suas folhas, parte estudada e proposta para constituir a droga vegetal.

4 caracterizar macro e microscopicamente as folhas para serem indicadas como a droga.

\efetuar triagem fitoquímica das folnas e do extrato hidroalcoólico (EHA) das folhas

Lavaliar o teor de taninos e saponinas das folhas e do extrato EHA

4quantificar e identificar os principais componentes químicos do óleo essencial obtido de folhas frescas.

$\triangle$ Avaliar as atividades: antimicrobiana; antiúlcera e antioxidante do extrato EHA

4 avaliar a toxicidade aguda do extrato EHA

4 avaliar a citotoxicidade do extrato EHA para artêmias. 


\section{MATERIAL E MÉTODOS}

\subsection{Material vegetal}

O material vegetal empregado no presente estudo encontra-se discriminado na tabela 2.

Tabela 2. Material vegetal empregado no estudo.

\begin{tabular}{llcl}
\hline \hline $\begin{array}{l}\text { Data da } \\
\text { coleta }\end{array}$ & Local & Descrição do material & Uso \\
\hline $20 / 09 / 1998$ & Limeira & $\begin{array}{c}\text { Plantas providas de } \\
\text { frutos imaturos }\end{array}$ & $\begin{array}{l}\text { Preparo de exsicatas. } \\
\text { Estudo farmacobotânico }\end{array}$ \\
$30 / 12 / 1998$ & Limeira & Plantas estéreis & Preparo de extrato hidroal- \\
& & & Coólico (EHA) \\
& & Obtenção de óleo essencial \\
& & Abordagem fitoquímica
\end{tabular}

Os ramos frutificados coletados em Limeira foram preparados visando à identificação da espécie. A espécie foi identificada por pesquisadora do Instituto de Botânica de São Paulo, SP. Exsicata referência do estudo encontra-se depositada no Herbário do referido Instituto tendo sido registrada sob a designação SP 329659. 


\subsection{Estudo Farmacobotânico}

A mensuração da altura da planta e do diâmetro do tronco foram efetuados com auxílio de fita métrica.

No estudo morfológico e anatômico foram empregadas folhas frescas elou fixadas com FAA 50 (formol: ácido acético glacial: etanol a $50 \%, 5: 5: 50$ ) e conservadas em álcool etílico 70\% (JOHANSEN,1940; SASS, 1951). O estudo das características macroscópicas da droga constituída de folhas, foi efetuado a olho nu e com auxilio de lupa estereoscópica de marca Willd®. A mensuração foi realizada com auxílio de régua.

A técnica empregada no estudo anatômico foi baseada em OLIVEIRA e AKISUE (1998), e SASS (1951). Os cortes transversais e paradérmicos obtidos a mão livre, foram submetidos a diafanização com solução aquosa de hipoclorito de sódio (1:1). Em seguida, os cortes foram lavados diversas vezes com água destilada. Posteriormente, foram tratados com solução aquosa de ácido acético a $1 \%$, lavados com água destilada e submetidos a coloração com azul de astra e fucsina básica. Os cortes foram montados entre lâminas e lamínulas empregando-se solução aquosa de glicerina (1:1). Nos testes histoquímicos, a suberina, a cutina e os materiais lipofilicos foram evidenciados pelo Sudam III, os cristais de oxalato de cálcio pela solução de ácido sulfúrico $10 \%$, a celulose pela solução de hematoxilina de Delafield, a lignina pela solução de floroglucina clorídrica, os amiloplastos pelo lugol, os taninos pela solução de cloreto férrico em etanol a 2\% (OLIVEIRA e AKISUE, 1998). Na observação das epidermes utilizou-se a técnica de dissociação com peróxido de hidrogênio e ácido acético (FRANKLIN, 1945). 


\subsection{Estudo químico}

\subsubsection{Obtenção da droga vegetal}

A droga vegetal, isto é a planta ou suas partes submetidas a processos de coleta, estabilização e secagem (RDC $n^{\circ} 17,2000$ ), foi obtida de folhas de C. xanthocarpa. As folhas frescas foram submetidas à secagem em estufa a 40 $-45^{\circ} \mathrm{C}$, com circulação de ar por 2 dias. O material desidratado foi. pulverizado em moinho de facas e martelos e passado por tamis de malha de 1 mm (FARM. BRAS., 1988). O pó obtido foi utilizado na elaboração do extrato liofilizado.

\subsubsection{Obtenção do extrato hidroalcoólico (EHA)}

O extrato foi elaborado com $2,250 \mathrm{Kg}$ de pó da droga vegetal obtida de folhas coletadas em $30 / 12 / 1998$. O pó foi umedecido com quantidade suficiente de líquido extrator (etanol a 70\%, v/v). Após 30 minutos, foi transferido para percolador de aço, permanecendo em maceração por 24 horas. A velocidade de percolação foi de 60 gotas por minuto. A droga foi percolada com cerca de 50 litros de líquido extrator. O extrato, mantido em geladeira a temperatura de $4{ }^{\circ} \mathrm{C}$, foi reunido e concentrado em evaporador semi-industrial de marca Precision Scientific®, com pressão reduzida e temperatura máxima de $50^{\circ} \mathrm{C}$, até a eliminação do etanol. Em seguida, os extratos aquosos foram liofilizados, em equipamento de marca Virtis@. O extrato liofilizado denominado de EHA, foi acondicionado em frascos de vidro âmbar providos de tampa e conservados em dessecador, tendo silica como agente desumidificante. 


\subsubsection{Triagem fitoquímica}

A triagem fitoquímica foi realizada segundo FANSWORTH (1966) e MATOS e MATOS (1989) com o pó da droga e confirmada com o extrato EHA. Os ensaios foram efetuados em duplicata. A análise cromatográfica em camada delgada foi efetuada conforme descrito no subitem 4.3.3.8

\subsubsection{Alcalóides}

A pesquisa de alcalóides foi realizada segundo métodos extrativos e analíticos convencionais. As fraçōes obtidas foram submetidas à análise com os 4 reagentes: Mayer, Dragendorff, Bouchardat e Bertrand.

A $2,0 \mathrm{~g}$ do pó da droga foram adicionados $10,0 \mathrm{~mL}$ de água destilada, e ácido clorídrico $0,2 \mathrm{~N}$, até $\mathrm{pH}$ ácido (verificado com papel indicador universal Merck®). O conjunto foi aquecido até fervura por 2 minutos. O filtrado foi transferido para um funil de separação, e em seguida adicionou-se solução de hidróxido de amônio a 10\%, até pH alcalino. Este extrato foi submetido à extração com 2 porções de $10,0 \mathrm{~mL}$ de éter etílico. O extrato etéreo foi concentrado à secura em evaporador Bücchi®. O resíduo foi suspenso com 2,0 $\mathrm{mL}$ de $\mathrm{HCL} 0,2 \mathrm{~N}$ e foi testado com os reagentes para alcalóides. Dois gramas do extrato (EHA) foram submetidos a procedimento semelhante ao pó da droga.

Reação de Bertrand: a 2 gotas da solução teste, colocada sobre uma lâmina de vidro, foi adicionada uma gota de solução aquosa de ácido silicotúngstico a 5\%. O desenvolvimento de precipitado foi considerado resultado positivo.

Reação de Mayer : a 2 gotas da solução teste, foi adicionada uma gota de solução do reativo de Mayer (solução de tetraiodomercurato de potássio). 0 desenvolvimento de precipitado foi considerado resultado positivo.

Reação de Dragendorff : a 2 gotas da solução teste, foi adicionado o reagente de Dragendorff (solução aquosa contendo ácido nítrico 6\%, 
subnitrato de bismuto a $8 \%$ e iodeto de potássio $23 \%$ ). O desenvolvimento de precipitado foi considerado resultado positivo.

Reação de Bouchardat: a 2 gotas da solução teste, foi adicionado o reagente de Bouchardat (solução aquosa de iodo em iodeto de potássio). O desenvolvimento de precipitado foi considerado resultado positivo.

\subsubsection{Antraquinonas}

\section{Reação de Borntraeger}

Cerca de $2,0 \mathrm{~g}$ do pó da droga foram fervidos com 10,0 mL de ácido sulfúrico $2 \mathrm{~N}$, durante 2 minutos. Após o resfriamento da solução, o filtrado foi extraído com $10,0 \mathrm{~mL}$ de éter etílico. À fase etérea, transferida para um tubo de ensaio, foram adicionados $2,0 \mathrm{~mL}$ de solução aquosa de hidróxido de sódio $2 \mathrm{~N}$. Após agitação, o desenvolvimento de coloração vermelha intensa na fase aquosa, foi considerada reação positiva.

Dois gramas do extrato (EHA) foram submetidos a procedimento semelhante ao pó da droga.

\subsubsection{Glicosídeos Cardiotônicos}

Dois gramas do pó da droga, foram aquecidos à fervura durante 1 minuto com $20,0 \mathrm{~mL}$ de etanol a $50 \%(\mathrm{v} / \mathrm{v})$ e a seguir filtrados. A extração foi repetida por duas vezes com o mesmo solvente. Ao filtrado, foram adicionados $10,0 \mathrm{~mL}$ de solução saturada de acetato básico de chumbo. Após a agitação, a mistura permaneceu em repouso até sedimentação do precipitado formado. $O$ líquido sobrenadante foi filtrado e extraído com duas porções de 15,0 mL de clorofórmio cada. Os extratos clorofórmicos foram filtrados através de sulfato de sódio anidro. Dois gramas do extrato (EHA) foram submetidos a procedimento semelhante ao pó da droga. 


\section{Reação do núcleo esteroidal (Liebermann-Burchard)}

Cerca de $3,0 \mathrm{~mL}$ de extrato clorofórmico foram concentrados. 0 resíduo foi retomado com cerca de $0,5 \mathrm{~mL}$ de anidrido acético $R$ e transferido para um tubo de ensaio contendo $1,0 \mathrm{~mL}$ de ácido sulfúrico concentrado. O desenvolvimento de coloração castanho-avermelhada, na região de contato entre os dois líquidos, foi considerado reação positiva.

\section{Reação de identificação do anel lactônico pentagonal (Reação de Kedde)}

Cerca de $3,0 \mathrm{~mL}$ do extrato clorofórmico foram concentrados, Ao resíduo foram adicionadas 4 gotas de solução alcoólica a $1 \%$ de ácido 3,5 dinitrobenzóico e duas gotas de hidróxido de potássio $1 \mathrm{~N}$. O desenvolvimento de coloração vermelho- violácea intensa, foi considerada reação positiva.

\section{\Reação de identificação do anel lâctonico pentagonal (Reação de Baljet)}

Foram concentrados $3,0 \mathrm{~mL}$ do extrato clorofórmico. Ao resíduo foram adicionados 5 gotas de ácido pícrico (2,4,6-trinitrofenol) a 0,5\% e duas gotas de solução de hidróxido de potássio $1 \mathrm{~N}$. O desenvolvimento de coloração alaranjada intensa, foi considerado reação positiva.

\section{Reação de 2- desoxiaçúcares (Reação de Killer-Killiani)}

Cerca de $3,0 \mathrm{~mL}$ do extrato clorofórmico foram concentrados, e o resíduo foi dissolvido em $1,0 \mathrm{~mL}$ de ácido acético glacial. À solução, foram adicionadas 2 gotas de solução aquosa de cloreto férrico a $2 \%$. Em seguida, a mistura foi transferida cuidadosamente, através das paredes, para um tubo de ensaio contendo cerca de $1,0 \mathrm{~mL}$ de ácido sulfúrico concentrado. 0 desenvolvimento de coloração castanho-avermelhada na zona de contato entre os líquidos, foi considerado reação positiva. 


\subsubsection{Flavonóides}

Dois gramas do pó da droga, foram submetidos à fervura com 15,0 mL de etanol a $70 \%(\mathrm{v} / \mathrm{v})$, durante dois minutos. Com o extrato filtrado foram realizadas as seguintes reações de identificação: reação com cloreto de alumínio, reação de Shinoda e reação com hidróxidos alcalinos. Dois gramas do extrato liofilizado, foram submetidos ao processo de extração e de identificação semelhante ao pó da droga.

\section{Reação com cloreto de alumínio}

Duas diferentes áreas de um papel de filtro foram umedecidas com solução alcoólica do pó da droga e do extrato EHA. Em uma das regiões umedecidas, adicionou-se uma gota de solução etanólica de cloreto de alumínio a $5 \%$. Foi comparada a fluorescência na região das duas áreas (com o reativo e sem o reativo) sob luz ultra violeta de ondas longas (366 nm). 0 desenvolvimento ou intensificação de fluorescência na região de contato do extrato com o reativo, foi considerado indicativo da presença de flavonóides.

\section{Reação de Shinoda}

Dois a três fragmentos de magnésio metálico e $1 \mathrm{~mL}$ de ácido cloridrico concentrado foram adicionados a $2,0 \mathrm{~mL}$ do extrato hidroalcoólico. $\mathrm{O}$ desenvolvimento de coloração rósea a vermelha foi considerado indicativo da presença de flavonóides.

\section{Reação com hidróxidos alcalinos}

A 2,0 ou 3,0 mL do extrato foram acrescentados $0,5 \mathrm{~mL}$ de solução de hidróxido de sódio $1 \mathrm{~N}$. A intensificação da cor amarela foi considerado indicativo da presença de flavonóides. 


\subsubsection{5. Óleos essenciais}

\section{Avaliação organoléptica}

A folhas frescas foram trituradas entre os dedos. O desprendimento de odor aromático foi considerado resultado positivo.

\section{Avaliação no hidrodestilado}

Um anel metálico de cerca de $1,5 \mathrm{~cm}$ de diâmetro por 0,5 de altura colocado na superfície de uma lâmina microscópica, foi preenchido com o pó da droga vegetal umedecido com água; sobre o anel foi colocada outra lâmina. O conjunto foi aquecido brandamente. Após o aparecimento do condensado na lâmina superior, foi repetido o processo trocando as lâminas por 4 vezes. Sobre o condensado foi colocada uma gota de Sudam III e lamínula, sendo o conjunto observado ao microscópio de luz Olympus $®$. A coloração vermelhoalaranjada das gotículas dispersas no meio aquoso, foi considerada indicativa da presença de substâncias lipofilicas voláteis.

\subsubsection{Glicosídeos saponínicos}

Cerca de $2,0 \mathrm{~g}$ do pó da droga foram fervidos com 20,0 mL de água destilada durante 2 minutos. $O$ extrato filtrado e recolhido em tubo de ensaio com tampa, foi agitado vigorosamente por cerca de um minuto. A presença de espuma persistente foi considerado resultado positivo para saponinas.

Os índices de espuma e de hemólise foram avaliados para a droga e para o extrato EHA. Cerca de $0,5 \mathrm{~g}$ do pó da droga, foram levados a fervura durante 2 minutos com $20 \mathrm{~mL}$ de água destilada. $O$ filtrado foi transferido para balão volumétrico de $50 \mathrm{~mL}$. Novas extrações do mesmo pó, com porções de $10 \mathrm{~mL}$ de água destilada, foram efetuadas até completar o volume. Quinhentos miligramas do extrato EHA foram submetidos a procedimento semelhante ao 
do pó da droga. Os extratos aquosos a $1 \%$ assim obtidos foram utilizados nas avaliações seguintes:

\section{4 Índice de espuma}

Em dez tubos de ensaio de igual dimensão e identificados em seqüência numérica, foram adicionados $5 \mathrm{~mL}$ de água destilada em todos os tubos, exceto no primeiro. Adicionou-se $5,0 \mathrm{~mL}$ de extrato saponínico a $1 \%$ no primeiro e no segundo tubo e homogeneizado o conteúdo. Foram transferidos $5,0 \mathrm{~mL}$ da solução do segundo tubo para o terceiro tubo. O processo foi realizado seqüencialmente, até o décimo tubo, usando-se a mesma pipeta. Cinco mililitros do décimo tubo foram desprezados. Todos os tubos foram agitados vigorosamente ao mesmo tempo, no sentido longitudinal, durante 15 segundos, e deixados em repouso por 15 minutos. Observou-se, ao final do período, em qual dos tubos permaneceu uma camada de espuma de $1 \mathrm{~cm}$ de altura.

\section{४índice de hemólise}

Dez tubos de ensaio de iguais dimensões foram numerados. Foram colocados $5,0 \mathrm{~mL}$ de solução fisiológica em todos os tubos, exceto no primeiro. Cinco mililitros do extrato aquoso previamente isotonisado, com cloreto de sódio, foram colocados no primeiro e no segundo tubo e homogeneizado o conteúdo. Foram transferidos $5,0 \mathrm{~mL}$ da solução do segundo tubo para o terceiro tubo, agitando-se bem. O processo foi realizado seqüencialmente, até o décimo tubo, usando-se a mesma pipeta. Cinco mililitros do décimo tubo foram desprezados. Foram adicionados $2,0 \mathrm{~mL}$ de uma suspensão de sangue bovino desfibrinado a $2 \%$, em solução fisiológica, a todos os tubos, e submetendo-se a homogeneização. Após uma hora de repouso, foi observado qual dos tubos apresentou hemólise, determinado-se o índice de hemólise (IH). 


\subsubsection{Taninos}

Um grama do pó da droga, foi fervido durante 5 minutos com 50,0 mL de água destilada (concentração de $0,02 \mathrm{~g} / \mathrm{mL}$ ). Após resfriamento e filtração, aliquotas de $2,0 \mathrm{~mL}$ do filtrado foram separadas, para a realização dos ensaios de identificação descritos a seguir. Um grama do extrato liofilizado foi submetido a procedimento semelhante ao do pó da droga.

\section{Adstringência}

A sensação de adstringência foi avaliada empregando-se algumas gotas, do extrato aquoso obtido anteriormente.

\section{Reação com alcalóides}

Foram adicionados a $2,0 \mathrm{~mL}$ do filtrado, uma gota da solução de ácido clorídrico a $10 \%$ e 5 gotas de solução aquosa de sulfato de quinina a $0,1 \%$. O desenvolvimento de precipitado foi considerado reação positiva.

\section{Reação com acetato de chumbo}

Foram adicionadas a 2,0 mL do filtrado, 3 gotas de solução aquosa de acetato de chumbo a $10 \%$. O desenvolvimento de precipitado foi considerado resultado positivo.

\section{Reação com acetato de cobre}

Foram adicionadas a 2,0 mL do filtrado, 2 a 3 gotas de solução aquosa de acetato de cobre a $3 \%$. O desenvolvimento de precipitado foi considerado resultado positivo.

\section{Reações com sais de ferro}

A 2,0 $\mathrm{mL}$ do filtrado, foram adicionados $5,0 \mathrm{~mL}$ de água destilada, 2 a 3 
gotas de solução de cloreto férrico a $2 \%$. O desenvolvimento de coloração azul escuro e precipitado foi considerado resultado positivo.

\section{Reação com gelatina}

A $2,0 \mathrm{~mL}$ do filtrado foi adicionada 1 gota de ácido cloridrico a $10 \%$. Em seguida, $0,5 \mathrm{~mL}$ de gelatina a $2,5 \%$, gota a gota. $\mathrm{O}$ desenvolvimento de precipitado foi considerado resultado positivo.

\subsubsection{Análise cromatográfica em camada delgada dos principais} grupos de princípios ativos, segundo Wagner e Bladt (1996)

A $1,0 \mathrm{~g}$ do pó da droga vegetal foram adicionados $5,0 \mathrm{~mL}$ de metanol, e aquecido brandamente por 10 minutos sob refluxo. Com o extrato metanólico filtrado, foram realizadas as análises cromatográficas. Um grama do extrato EHA foi submetido a procedimento semelhante ao pó da droga.

$\mathrm{Na}$ análise cromatográfica em camada delgada foram empregados reativos de caracterização dos principais grupos de substâncias encontradas em Mirtaceas, isto é flavonóides e terpenos.

A análise dos extratos metanólicos da droga e do extrato EHA foram desenvolvidos com os seguintes sistemas cromatográficos:

\section{a) Sistema 1 :}

Fase estacionária: Placa cromatográfica de alta performance de silica gel, de $10 \times 10 \mathrm{~cm}$, marca Merck® .

Fase móvel: Tolueno: acetato de etila: ácido fórmico: água (35:55:5:5) (WAGNER e BLADT, 1996).

Aplicação do extrato metanólico: $10 \mu \mathrm{L}$

Substância de referência: solução metanólica a $1 \%$ de saponina, aplicação $10 \mu \mathrm{L}$.

Desenvolvimento: $8 \mathrm{~cm}$, cuba com saturação total . 
Revelador: Anisaldeído sulfúrico (AS) (WAGNER e BLADT, 1996).

\section{b) Sistema 2:}

Fase estacionária: Placas de sílica gel com indicador de fluorescência, de $20 \times 20 \mathrm{~cm}$ marca Merck® .

Fase móvel: Tolueno: acetato de etila : ácido fórmico: água (35: 55: 5: 5) (WAGNER \& BLADT, 1996).

Aplicação do extrato metanólico: $20 \mu \mathrm{L}, 100 \mu \mathrm{L}$

Substâncias de referência: $10 \mu \mathrm{L}$ de: rutina, ácido clorogênico, quercetina, apigenina e crisina (soluções metanólicas a 0,05\%).

Revelador: Iuz ultra-violeta 254 nm (WAGNER e BLADT, 1996)

\section{c) Sistema 3:}

Fase estacionária: Placas de sillica gel com indicador de fluorescência de $20 \times 20 \mathrm{~cm}$, marca Merck® .

Fase móvel: Acetato de etila: ácido fórmico: água (90: 10: 10)

Aplicação do extrato metanólico: $10 \mu \mathrm{L}$

Substâncias de referência: $10 \mu \mathrm{L}$ de: rutina, ácido clorogênico e quercetina (soluções metanólicas a 0,05 \%)

Desenvolvimento: $15 \mathrm{~cm}$, cuba com saturação total

Revelador: Éster 2-aminoetil do ácido difenil bórico (NP) e solução etanólica de polietileno glicol, e luz Ultra-violeta $366 \mathrm{~nm}$ (WAGNER \& BLADT, 1996).

\section{d) Sistema 4:}

Fase estacionária: Placas $20 \times 20 \mathrm{~cm}$, de sílica gel, marca Merck $($.

Fase móvel-Tolueno: acetato de etila (80:20), (WAGNER \& BLADT, 1996).

Aplicação de solução de óleo essencial a 10\% em clorofórmio: $5 \mu \mathrm{L}$. 
Desenvolvimento: $10 \mathrm{~cm}$, cuba com saturação total .

Substâncias de referência: linalol e acetato de linalila, (soluções a 10\% em clorofórmio). Aplicação $3 \mu \mathrm{L}$.

Revelador: Anisaldeído sulfúrico. (WAGNER \& BLADT, 1996).

\section{e) Sistema 5:}

Fase estacionária: placas de sílica gel de $20 \times 20 \mathrm{~cm}$, marca Merck®.

Fase móvel: tolueno: acetato de etila (8:2), (WAGNER e BLADT, 1996).

Aplicação de óleo essencial a 10\% em clorofórmio: $5 \mu \mathrm{L}$.

Substâncias de referência: linalol e acetato de linalila, (soluções a 10\% em clorofórmio). Aplicação de $3 \mu \mathrm{L}$.

Desenvolvimento: $10 \mathrm{~cm}$, cuba com saturação total

Revelador: Vanilina-ácido sulfúrico (WAGNER \& BLADT, 1996)

As substâncias químicas de referência rutina, quercetina e saponina

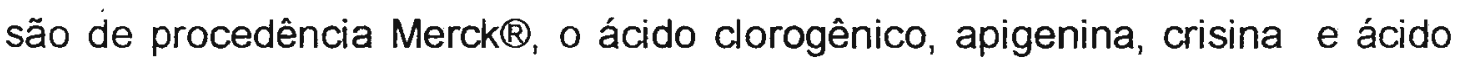
caféico da Sigma $\otimes$, e os óleos essenciais da Firmenich $\otimes$.

\subsubsection{Doseamento de taninos}

A avaliação do teor de taninos do pó da droga vegetal e do extrato $E H A$, foi realizada segundo métodologia descrita na FARMACOPÉIA EUROPÉIA (2001). O resultado foi expresso em porcentagem de polifenóis. O método determina o teor de polifenóis, pela reação destes com o ácido fosfotúngstico, utilizando como substância de referência o pirogalol com pureza de $99 \%$, marca Merck®. 


\subsubsection{Preparo das amostras e da solução do padrão}

\section{Amostra}

A $0,750 \mathrm{~g}$ do pó da droga vegetal foram adicionados $150 \mathrm{~mL}$ de água destilada em um erlenmeyer. O conjunto foi aquecido até a fervura em banho de água por 30 minutos. Após resfriamento, a mistura foi transferida quantitativamente para um balão volumétrico e completado o volume para 250 $\mathrm{mL}$ com água destilada. Após decantação dos sólidos, o líquido foi filtrado através de papel de filtro. Foram descartados os primeiros $50 \mathrm{~mL}$ e o restante denominado de F1. O extrato EHA foi submetido a tratamento similar. $O$ filtrado no ensaio foi denominado de F2.

\section{Solução padrão}

Sob proteção da luz, 50,0 mg da substância de referência (pirogalol) foram dissolvidos em $100 \mathrm{~mL}$ de água destilada. Cinco mililitros desta solução foram diluídos para $100 \mathrm{~mL}$ com água destilada. Foi construída uma curva de calibração, utilizando-se 4,0; 2,0 e 1,0 mL da solução diluida do padrão, para efetuar-se a reação como descrito no subitem 4.3.4.4.

\subsubsection{Doseamento de polifenóis totais}

A 5 mililitros de cada um dos filtrados denominados de $F_{1}$ e $F_{2}$ foram diluídos em um balão volumétrico de $25 \mathrm{~mL}$, com água destilada (F1 e F2). Cinco mililitros de cada uma das soluções diluídas, foram utilizadas na reação descrita no subitem 4.3.4.4.

\subsubsection{Doseamento de polifenóis não adsorvidos pelo pó de pele}

A $10,0 \mathrm{~mL}$ da cada um dos filtrados, denominados de $F_{1}$ e $F_{2}$, foi adicionado $0,1 \mathrm{~g}$ de pó de pele CRS, agitando-se vigorosamente por 60 
minutos. Cinco mililitros da cada filtrado foram diluídos a $25 \mathrm{~mL}$ com água destilada. Aliquotas de 5,0 mL (P1 e P2) de cada diluição foram empregadas para o desenvolvimento da reação descrita no subitem 4.3.4.4.

\subsubsection{Desenvolvimento da reação}

A 5 mililitros de cada uma das diluições reagentes foi adicionado $1,0 \mathrm{~mL}$ da solução de ácido fosfotúngstico $R$, e completados para $50 \mathrm{~mL}$ com solução de carbonato de sódio a $15 \%(\mathrm{p} / \mathrm{v})$. Exatamente após 2 minutos da adição do último reagente, mediu-se a absorbância a $715 \mathrm{~nm}$, usando-se água destilada como branco. As leituras das absorbâncias foram efetuadas em espectrofotômetro Heweltt Packard 8453 tipo Vectra XMS 45/120

\subsubsection{Cálculo}

Teor de taninos $=13,12\left(\mathrm{~A}_{1}-\mathrm{A}_{2}\right)$

A $3 \times \mathrm{m}$

Sendo: $A 1$ = absorbância antes do tratamento com pó de pele

A2 = Absorbância após tratamento com pó de pele

A3 = absorbância da solução de referência pirogalol

$\mathrm{m}=$ tomada de ensaio da amostra $(\mathrm{g})$

O resultado representa a média aritmética de 4 determinações.

\subsubsection{Doseamento de saponinas}

O doseamento de saponinas foi realizado segundo metodologia descrita por NAMBA e cols. (1974). Dez gramas do pó da droga vegetal foram extraídos com metanol em aparelho de Soxhlet. O extrato metanólico filtrado, foi concentrado a secura em rotaevaporador de marca Büchi®. O resíduo foi 
dissolvido em água destilada. A solução aquosa foi lavada com três porçōes de $30 \mathrm{~mL}$ de èter etílico. A seguir, a solução aquosa foi aquecida em banho de água até eliminação do éter. Após resfriamento, foi extraída com 5 porções de $40 \mathrm{~mL}$ de $n$-butanol saturado com água. O extrato butanólico foi lavado com água destilada e posteriormente concentrado até secura em rotaevaporador em balão previamente tarado. O resíduo foi seco em estufa a $80^{\circ} \mathrm{C}$, por 2 horas, resfriado e pesado. As pesagens foram repetidas até peso praticamente constante. O teor de saponinas representa a média aritmética de 2 determinações e foi expresso em porcentagem. Dez gramas do extrato EHA foram submetidos a procedimento semelhante ao do pó da droga vegetal.

\subsection{6. Óleo essencial}

\subsubsection{Determinação do teor de óleo essencial por hidrodestilação}

O óleo essencial foi extraído das folhas frescas adequadamente rasuradas, utilizando-se o aparelho de Clevenger modificado, segundo WASICKY e AKISUE (1969). Procedeu-se a extração por 4 horas (FARM. BRAS.,1988). Medido o volume do óleo obtido, calculou-se a porcentagem em relação ao peso das folhas frescas.

\subsubsection{Análise do óleo essencial por cromatografia gasosa acoplada a espectrômetro de massas (CG/EM).}

O óleo essencial obtido da planta fresca, por hidrodestilação, foi analisado pelo Departamento de Química da Universidade Federal do Pará, por cromatografia em fase gasosa, acoplado a espectrômetro de massas, a fim de verificar sua composição química.

O sistema cromatográfico utilizado foi: 
Equipamento: Cromatógrafo a gás acoplado a espectrômetro de massas (CG/EM) marca Finnigan INCOS-XL.

Coluna capilar: DB-5MS $(30 \mathrm{~m} \times 0,25 \mathrm{~mm} ; 0,25 \mu \mathrm{m}$ de espesura de filme)

Temperatura do injetor: $220^{\circ} \mathrm{C}$. Fluxo do hélio : velocidade linear de 32 $\mathrm{cm} / \mathrm{s}$.

Temperatura inicial: $60^{\circ} \mathrm{C}$. Temperatura final : $240^{\circ} \mathrm{C}$. Rampa: $3^{\circ} \mathrm{C} / \mathrm{min}$.

Volume injetado: $1 \mu \mathrm{L}$ (solução em n-hexano).

Espectrômetro de massas de impacto eletrônico (70 e V) e com fonte de íons a temperatura de $180^{\circ} \mathrm{C}$.

A identificação dos componentes químicos foi baseada na comparação dos espectros de massas e tempos de retenção, com aqueles existentes nas bibliotecas do sistema de dados e citados na literatura. Os índices de retenção foram calculados para os componentes usando uma série homóloga de alcanos. 


\subsection{Ensaios biológicos}

\subsubsection{Toxicidade Aguda}

\subsubsection{Preparo da Amostra}

O extrato EHA de C. xanthocarpa, empregado no ensaio de toxicidade aguda, foi solubilizado em água potável, na concentração de $0,5 \mathrm{~g} / \mathrm{mL}$.

\subsubsection{Animais}

Camundongos machos e fêmeas adultos, Swiss, pesando entre 27,8 e $37,2 \mathrm{~g}$ foram procedentes do Biotério da Faculdade de Medicina da Universidade de São Paulo. As fêmeas eram nuliparas e não- prenhas. Os grupos coritrole e teste foram constituidos de 5 machos e 5 fêmeas.

$\mathrm{Na}$ semana anterior ao inicio do experimento, os animais mantidos em gaiolas apropriadas, foram adaptados ao ambiente do ensaio. O ciclo de claroescuro foi regulado para $12 / 12 \mathrm{hs}$, a temperatura ambiente regulada para 20 ${ }^{\circ} \mathrm{C}$, sendo fornecida ração Nuv lab-Nuvital@ e água, "ad libitum". O fornecimento de ração foi interrompido 3 horas antes do início do ensaio.

\subsubsection{Ensaio}

O ensaio de toxicidade aguda por via oral, foi realizado segundo metodologia preconizada por BRITO (1994). Os animais teste e controle foram submetidos à pesagem. O extrato para os grupos teste, e água potável para os grupos controle, foram administrados por via oral, com auxílio de uma cânula gástrica metálica, na dose única de $5 \mathrm{~g} / \mathrm{Kg}$ de peso corporal. A quantidade a ser administrada foi calculada individualmente, sendo que para roedores, a metodologia sugere a aplicação de um volume inferior ou igual à $1 \mathrm{~mL} / 100 \mathrm{~g}$ de peso do animal.

Os grupos teste e controle receberam ração e água 4 horas após a administração do extrato. 
O comportamento dos animais foi observado e registrado após a administração e em seguida, em intervalos de 30 minutos durante 6 horas. Após este periodo, as observações foram realizadas a cada 24 horas, por 14 dias consecutivos incluindo o dia do experimento. A massa corpórea, os consumos de ração e de água foram registrados diariamente para todos os animais.

Após 14 dias, os animais anestesiados com éter etílico, foram sacrificados e necropsiados. As alterações macroscópicas dos, corações, fígados, pulmões, e rins foram analisadas, bem como anotados seus dados relativos a massa relativa e massa corpórea dos animais.

Análise estatística: os resultados de massa corpórea, massa relativa de rins, fígado e coração + pulmões, são expressos como média \pm epm. Os dados foram analisados estatisticamente por análise única de variança. As diferenças estatísticas das médias entre os grupo controle e tratados foram calculadas para nivel de $p<0,05$, utilizando-se o teste comparativo de Student.

\subsubsection{Ensaio da Letalidade da Artêmia sp}

\subsubsection{Preparo da amostra}

Foram dissolvidos $5,0 \mathrm{mg}$ do extrato EHA, em tubo de ensaio de capacidade de $10,0 \mathrm{~mL}$, com $5,0 \mathrm{~mL}$ de água de mar artificial.

\subsubsection{Preparo de água de mar artificial e obtenção de artêmias}

Água de mar artificial foi preparada de acordo com o fabricante (San Francisco Bay Brand \# 65034) e colocada em um recipiente plástico opaco. A aeração da água foi mantida com bomba para aquário. Colocou-se uma divisória de plástico com orifícios na parte inferior, separando-se o recipiente em dois, na proporção de 2:1. Os ovos foram colocados na parte mais larga do recipiente, a qual deve ficar sem iluminação, cobrindo-se com papel de alumínio. A parte menor foi iluminada com luz fria (fluorescente). Após 48 horas, as artêmias que 
eclodiram passaram para a parte iluminada, enquanto o restante dos ovos permaneceu na parte maior do compartimento, sem iluminação.

\subsubsection{Ensaio prévio}

O método utilizado no ensaio da letalidade da Artêmia sp, foi o descrito por MEYER e cols. (1982).

Dez artêmias foram transferidas, com pipeta Pasteur, para tubos de ensaio com capacidade para $10,0 \mathrm{~mL}$, que já continham $5,0 \mathrm{mg}$ do extrato EHA. Neste tubo, adicionou-se $5,0 \mathrm{~mL}$ de água de mar artificial e uma gota de fermento biológico diluido em água que serve de alimento para as artêmias. As sobreviventes foram contadas após 24 e 48 horas, sendo mantidas sob iluminação.

\subsubsection{Determinação da DL50 do extrato EHA em Artêmias}

Foram dissolvidos $10,0 \mathrm{mg}$ do extrato EHA em água de mar artificial desta solução, foram transferidos com micropipeta, 0,$5 ; 0,1$; e $0,02 \mathrm{~mL}$ para tubos de ensaio com capacidade de $10,0 \mathrm{~mL}$. O controle negativo foi realizado da mesma maneira que o da letalidade, descrito anteriormente, empregando-se água do mar artificial como diluente.

A determinação da DL50, foi efetuada a partir da contagem das artêmias sobreviventes, após 24 horas. O cálculo da DL50 e do limite de confiança de 95\%, foi realizado pelo método FINNEY (1971), empregando-se o programa denominado TAXONOMY.

A padronização do ensaio foi realizada, com a substância química de referência secundária, vincristina cedida pela Eli Lilly do Brasil.

\subsubsection{Atividade Antimicrobiana}

O ensaio de atividade antimicrobiana do extrato EHA de C. xanthocarpa foi realizado pelo método de diluição em meio de cultura líquida (THE 
NATIONAL COMMITEE FOR CLINICAL LABORATORY STANDARS-M 7-A S. 2000).

\subsubsection{Microrganismos}

Foram empregados os seguintes microrganismos no ensaio:

Staphylococcus aureus (ATCC 6538)

Escherichia coli (ATCC 10536)

Pseudomonas aeruginosa (ATCC 9027)

Salmonella choleraesuis (ATCC 10708)

Candida albicans (ATCC 10231)

Aspergillus niger (ATCC 16404).

\subsubsection{Meios de Cultura}

Os meios de cultura empregados foram:

Caldo e ágar- caseína soja (DIFCOß)

Caldo e ágar Sabouraud-dextrose (DIFCOR)

\subsubsection{Preparo dos meios de cultura}

Os meios de cultura foram preparados a partir do meio desidratado, conforme instrução do fabricante.

\subsubsection{Preparo da solução fisiológica estéril}

A solução fisiológica, preparada com cloreto de sódio p.a Merck®, na concentração de 0,9\% em água destilada, foi distribuída em alíquotas de 9,0 $\mathrm{mL}$ em tubos de ensaio. O conjunto foi submetido à esterilização em autoclave a $121^{\circ} \mathrm{C}$ por 15 minutos.

\subsubsection{Preparo e padronização das suspensões de microrganismos}

A partir das culturas estoque, as espécies bacterianas foram semeadas 
em estrias, na superfície do meio inclinado de ágar caseína-soja, incubando-se os tubos em estufa a $30-35^{\circ} \mathrm{C}$, durante 24 horas. A levedura e o fungo foram semeados na superfície do meio inclinado de ágar Sabouraud-dextrose e incubados a $25^{\circ} \mathrm{C}$ por 48 horas.

A massa celular resultante do crescimento foi recolhida, na sua totalidade, com 9,0 mL de solução fisiológica estéril, e a suspensão obtida foi submetida à contagem de microrganismos viáveis pela técnica de semeadura em profundidade. Para isto foi transferida 1 gota da suspensão original para um tubo contendo $9,0 \mathrm{~mL}$ de solução fisiológica estéril. A partir desta nova suspensão, foram efetuadas diluições decimais seriadas em $9,0 \mathrm{~mL}$ de solução fisiológica estéril até $10^{-6}$.

Alíquotas de $1,0 \mathrm{~mL}$ das diluições de $10^{-4}, 10^{-5}$ e $10^{-6}$ de bactérias, fungos e leveduras foram transferidas para placas de Petri em duplicata e homogeneizadas com cerca de $15,0 \mathrm{~mL}$ de meio de cultura esterilizado de ágarcaseina para bactérias, e ágar Sabouraud-dextrose para levedura e fungo. Seguindo-se o mesmo padrão de incubação descrito anteriormente, efetuou-se a contagem de colônias com o contador Phoenix $(B)$.

O número de unidades formadoras de colônias por $\mathrm{mL}$ (UFC/mL) da suspensão original foi determinado, considerando-se a contagem das placas com cerca de 30 a 300 UFC/mL.

A partir da suspensão original de cada microrganismo de carga conhecida foram efetuadas diluições em solução fisiológica estéril até obtenção de suspensão com $10^{3} \mathrm{UFC/mL}$.

\subsubsection{Preparo das soluções dos antibióticos}

Para controle negativo, foi utilizado padrão secundário de ampicilina anidra de potência $970 \mu \mathrm{g} / \mathrm{mg}$ de procedência Sigma, na concentração de 100 $\mu \mathrm{g} / \mathrm{mL}$ para E. coli; $10 \mu \mathrm{g} / \mathrm{mL}$ para $S$. aureus; $185 \mu \mathrm{g} / \mathrm{mL}$ para $P$. aeruginosa e o padrão secundário de Nistatina de potência 5874 Ul/mg procedente da Bristol Meyers, na concentração de $350 \mu \mathrm{g} / \mathrm{mL}$ para C. albicans e para A. niger 600 $\mu \mathrm{g} / \mathrm{mL}$, em salina estéril. 


\subsubsection{Preparo da amostra}

Quantidades suficientes do extrato EHA foram pesadas para a obtenção das concentrações de $10 \mathrm{mg} / \mathrm{mL}, 5 \mathrm{mg} / \mathrm{mL}$ e $1 \mathrm{mg} / \mathrm{mL}$, em salina estéril.

\subsubsection{Avaliação da atividade antimicrobiana}

A inoculação dos microrganismos foi feita ao meio de cultura, e para isto, foi transferida alíquota de $0,1 \mathrm{~mL}$ da suspensão de cultura jovem com carga de $10^{3} \mathrm{UFC} / \mathrm{mL}$ para $9,0 \mathrm{~mL}$ do meio de cultura e $1,0 \mathrm{~mL}$ da solução da amostra, sendo as concentrações finais desta nos meios de cultura de $1 \mathrm{mg} / \mathrm{mL}, 0,5$ $\mathrm{mg} / \mathrm{mL}$ e $0,1 \mathrm{mg} / \mathrm{mL}$.

A incubação do meio de cultura contendo os microrganismos foi a 30-35 ${ }^{\circ} \mathrm{C}$ por 24 horas para bactérias e levedura, e para o fungo a incubação foi a 25 ${ }^{\circ} \mathrm{C}$ por 120 horas. Em seguida, foi realizada a observação macroscópica do crescimento bacteriano (ausência ou presença de turvação e formação de colônias). O teste foi realizado duas vezes em triplicata para: controle positivo, negativo, diluente, e para a amostra de $C$. xanthocarpa nas concentrações de 1 $\mathrm{mg} / \mathrm{mL}, 0,5 \mathrm{mg} / \mathrm{mL}$ e $0,1 \mathrm{mg} / \mathrm{mL}$.

Para os tubos que não apresentaram turvação porém precipitado, foram realizadas sub-culturas, para avaliar novamente o crescimento ou não dos microrganismos.

\subsubsection{Avaliação da Concentração Inibitória Mínima (CIM)}

Foram avaliadas as CIMs do extrato EHA de $C$. xanthocarpa em relação ao crescimento de Staphylococcus aureus nas concentrações de: 0,$5 ; 0,4 ; 0,3$; 0,2 e 0,1 $\mathrm{mg} / \mathrm{mL}$. Em relação ao crescimento de Salmonella choleraesuis foram empregadas as concentrações de 0,1;0,05; e 0,025 mg/mL de EHA e em relação ao crescimento de Candida albicans nas concentrações de 1,0;0,5;0,4; 0,3 e $0,2 \mathrm{mg} / \mathrm{mL}$. Os valores de CIMs foram as menores concentrações do extrato EHA de C. xanthocarpa que inibiram o crescimento dos microrganismos. 
Os valores dos CIMs de ampicilina sódica e nistatina foram determinados segundo WADT e cols. (1996).

\subsubsection{Atividade Antiúlcera}

\subsubsection{Preparo da Amostra}

O extrato EHA de C. xanthocarpa foi dissolvido com água potável obtendo-se uma concentração de $40 \mathrm{mg} / \mathrm{mL}$.

\subsubsection{Preparo do controle positivo (Misoprostol)}

Um comprimido contendo $200 \mu \mathrm{g}$ de Misoprostol (Citotec $\otimes$ Searle), foi dissolvido com $20 \mathrm{~mL}$ de água potável, obtendo-se uma concentração de 10 $\mu \mathrm{g} / \mathrm{mL}$.

\subsubsection{Controle negativo}

Água potável foi empregada como controle negativo.

\subsubsection{Animais}

Ratos Wistar fêmeas, com peso entre 130 e $180 \mathrm{~g}$, provenientes do Biotério da Faculdade de Ciências Farmacêuticas, da Universidade de São Paulo foram empregados no ensaio.

\subsubsection{Ensaio}

O ensaio de atividade antiúlcera foi realizado empregando-se o modelo de indução aguda por ácido clorídrico a 0,3 $\mathrm{M}$ em etanol a $60 \%$, (GUARALDO e cols., 2001). Os animais permaneceram em jejum por 24 horas antes do ensaio, com livre acesso a água. Foram utilizados 11 animais para o controle negativo (água potável), 11 animais para a amostra (extrato EHA de C. xanthocarpa), e 10 animais para o padrão (Misoprostol). 
Aos grupos controle negativo, padrão e amostra foram administrados por via oral, volumes de $1,0 \mathrm{~mL} / 100 \mathrm{~g}$ de peso do animal, de água potável, das soluções de misoprostol (10 $\mu \mathrm{g} / \mathrm{mL})$ e do extrato de EHA (40 mg/mL), respectivamente. Após 30 minutos foi administrado a todos os animais, por via oral, o agente indutor, ácido clorídrico 0,3 $\mathrm{M}$ em etanol a $60 \%(\mathrm{v} / \mathrm{v})$, na dose de 1 $\mathrm{mL} / 100 \mathrm{~g}$ de peso do animal.

Ao final de uma hora da aplicação do indutor, os animais foram sacrificados com éter etílico para remoção dos estômagos. Estes foram abertos pela curvatura maior, lavados com água, e fixados em isopor para exame macroscópico das ulcerações. As ulcerações foram classificadas em níveis l, II e III, como segue:

Nivel 1 - ulcerações pontuais (petéquias)

Nivel II - ulcerações médias (úlceras estreitas)

Nível III - ulcerações de grande extensão (hemorrágicas)

O índice de lesão foi calculado para cada grupo, através da somatória do número de ulcerações do nível I, II e III.

Análise estatística: os resultados são expressos como média \pm epm. Os dados foram analisados estatisticamente por análise única de variança. As diferenças estatísticas das médias entre os grupo controle, padrão e tratados foram calculadas para nível de $p<0,05$, empregando-se o teste comparativo de Tuckey.

\subsubsection{Atividade Antioxidante}

\subsubsection{Cromatografia em camada delgada}

$A$ avaliação da presença de substâncias antioxidantes no extrato EHA de C. xanthocarpa, foi realizada segundo PRATT E MILLER (1984) em placas cromatográficas.

Os sistemas cromatográficos empregados foram: 


\section{Sistema 6}

Fase estacionária - placas de sílica gel F $254 \mathrm{~nm}$ de $20 \times 20 \mathrm{~cm}$, Merck®

Fase móvel -. tolueno: acetato de etila: ácido fórmico: água (35:55:5:5)

\section{Sistema 7}

Fase estacionária - placas de sílica gel F 254nm $20 \times 20 \mathrm{~cm}$, Merck $\otimes$

Fase móvel- acetato de etila: ácido fórmico: água (9:1:1)

\section{Sistema 8}

Fase estacionária- placas de celulose microcristalina da MercK®

Fase móvel- ácido acético: água (3:7)

Para os sistemas 6, 7, e 8 aplicaram-se as seguintes condições:

Desenvolvimento - ascendente, percurso de $15 \mathrm{~cm}$

Substâncias químicas de referência- rutina, quercetina, crisina, ácido clorogênico e apigenina a $1 \%$ em metanol, aplicação de $10 \mu \mathrm{L}$ Amostra: EHA de C. xanthocarpa a 1\% em metanol, aplicação de $50 \mu \mathrm{L}$. Revelador - solução de $\beta$-caroteno a 2 \% em clorofórmioletanol (1:1) Após a avaliação da presença de substâncias antioxidantes no extrato EHA de C. xanthocarpa, o mesmo foi submetido aos ensaios de atividade antioxidante "in vitro" descritos a seguir: técnica da medida de malonildialdeido e avaliação do efeito do extrato EHA de C. xanthocarpa sobre a cinética de oxidação de Lipoproteínas de Baixa Densidade (LDL) induzida por sulfato de cobre.

\subsubsection{Técnica da "medida de malonildialdeído" (MDA)}

\section{Preparo da amostra}

Duzentos miligramas do extrato EHA de C. xanthocarpa, foram dissolvidos em 100,0 mL de água ultrapurificada. Após homogeneização, foi 
obtida a concentração de $2,0 \mathrm{mg} / \mathrm{mL}$, a partir da qual realizaram-se as diluições utilizadas no ensaio.

\section{Preparo do homogenato de cérebros de ratos}

Ratos Wistar, machos, com peso de cerca de $350 \mathrm{~g}$, foram anestesiados com éter etílico e perfundidos com solução tampão fosfato $140 \mathrm{mM}$ de pH 7,4, através da artéria aorta. Os cérebros foram retirados, pesados, e homogeneizados com a mesma solução tampão, na proporção de 1:5 do seu peso. A mistura foi centrifugada (centrifuga Hitachi) a $3000 \mathrm{rpm}$ a $4^{\circ} \mathrm{C}$ por 15 minutos. O sobrenadante foi diluido com o tampão fosfato na proporção de 1:4 e conservado sob refrigeração.

\section{4 "Medida do malonildialdeído" (MDA)}

A atividade antioxidante do extrato de C. xanthocarpa foi avaliada pela técnica da medida de malonildialdeído (MDA). O ensaio foi realizado segundo metodologia descrita por STOCKS e cols. (1974), em quadruplicata.

A 3,0 mL do homogenato obtido foram acrescentados $50,0 \mu \mathrm{L}$ da amostra diluída. Para o controle, a $3,0 \mathrm{~mL}$ do homogenato foram adicionados $50,0 \mu \mathrm{L}$ do diluente da amostra.

Foi reservado para o tempo zero (To), 1,0 mL das preparações da amostra e do seu diluente com o homogenato, em tubos de ensaio, nos quais foi acrescentado $1,0 \mathrm{~mL}$ de solução de ácido tricloroacético a 5\% (TCA 5\%).

O restante da preparação da amostra foi mantido por uma hora, a $37^{\circ} \mathrm{C}$, sob agitação em banho de Dubnoff (Gyratory Water Bath Shaker modelo G 76New Brunewick Scientific(B)). Em seguida $1,0 \mathrm{~mL}$ desta preparação foi transferida para tubo de ensaio contendo $1,0 \mathrm{~mL}$ de TCA $5 \%$ (tuboT1).

A seguir, as preparações do tubo To e tubo T1, foram centrifugadas a 3000 rpm por 15 minutos, em equipamento de marca Clínica-Spin IV-Incibrás $®$.

De cada um dos tubos (Toe $\mathrm{T}_{1}$ ), foi retirado $1,0 \mathrm{~mL}$ do sobrenadante e acrescentado 1,0 mL de solução de ácido tiobarbitúrico a 0,67 \% (TBA 0,67 \%). 
O conjunto foi levado ao aquecimento em banho de água fervente por 20 minutos.

Imediatamente após o aquecimento, foi efetuado um resfriamento por 20 minutos em banho de gelo.

A leitura foi efetuada a $535 \mathrm{~nm}$, em espectrofotômetro Incibrás $\mathbb{B}$

Cálculo :

1 - Absorbância das amostras $\left[\mathrm{T}_{\left.1-\mathrm{T}_{0}\right]} \times 100=\%\right.$ da Capacidade

Absorbância dos controles [ $\left.\mathrm{T}_{1}-\mathrm{T}_{0}\right] \quad$ antioxidante (\%CAOx)

4.4.5.3. Avaliação do efeito do extrato EHA de C. xanthocarpa na cinética de oxidação da LDL induzida por sulfato de cobre. Análise da Cinética no processo de Oxidação: "Lag-time", e "Peak-time".

\section{Preparo da amostra}

O extrato EHA de Campomanesia xanthocarpa, dissolvido em água ultrapurificada, na concentração de $200 \mu \mathrm{g} / \mathrm{mL}$ foi empregado no ensaio.

Isolamento de lipoproteína de baixa densidade (LDL) de plasma humano.

Dez mililitros de sangue venoso humano foram coletados em um tubo vacutainer contendo ácido etileno diaminotetracético (EDTA), onde a concentração final de EDTA no sangue era de $1 \mathrm{mg} / \mathrm{mL}$. O plasma foi separado imediatamente por centrifugação a baixa velocidade (2500 rpm) por 10 minutos a $4{ }^{\circ} \mathrm{C}$. A densidade do plasma foi ajustada para $1,210 \mathrm{~g} / \mathrm{mL}$ com cloreto de sódio, e adicionada uma combinação de inibidores de proteases (PMSF 1mM, aprotinina $2 \mathrm{mg} / \mathrm{mL}$ e benzamidina $2 \mathrm{mM}$ ), segundo HAVEL (1995). A LDL foi separada escolhendo-se uma faixa de gradiente de densidade entre 1,019 1,210. Gradientes foram formados por camadas de $3,0 \mathrm{~mL}$ de plasma, cloreto de sódio e água. Na segunda ultracentrifugação, o plasma foi centrifugado a 
38.000 rpm em aparelho de marca Beckman L8-55 equipada com um rotor SW41 e refrigeração para $4^{\circ} \mathrm{C}$, durante 24 horas. Em seguida, a fração de LDL com densidade entre 1,019 e 1,065, foi removida por aspiração e submetida à diálise em tampão $\mathrm{pH} 7,4(\mathrm{NaCl} 150 \mathrm{mM}$, NaN3 $3 \mathrm{mM}$ e Tris $10,0 \mathrm{mM})$ a $4{ }^{\circ} \mathrm{C}$ durante 12 hs, ao abrigo da luz

O teor de proteínas na LDL isolada foi determinado pelo método de LOWRY e cols. (1951), utilizando albumina bovina como padrão.

\section{Oxidação de lipoproteínas de baixa densidade (LDL)}

As soluções de: LDL foi preparada na concentração de $500 \mu \mathrm{g} / \mathrm{mL}$ de proteínas no ensaio segundo MORIEL (2000), e de sulfato de cobre na concentração de $120 \mu \mathrm{M}$, no volume da reação de $2,0 \mathrm{~mL}$ no ensaio.

Seis tubos foram preparados. Em todos foi colocado o mesmo volume de LDL (59 $\mu \mathrm{L})$; tampão fosfato (PBS) nos volumes de: $1.821 \mu \mathrm{L} ; 1.819,5 \mu \mathrm{L}$; $1.817,88 \mu \mathrm{L} ; 1.814,75 \mu \mathrm{L} ; 1.808,50 \mu \mathrm{L} ; 1.796 \mu \mathrm{L} ;$ o extrato EHA diluído de $C$. xanthocarpa nos volumes de: $0 \mu \mathrm{L} ; 1,5 \mu \mathrm{L} ; 3,12 \mu \mathrm{L} ; 6,25 \mu \mathrm{L} ; 12,5 \mu \mathrm{L}$ e $25 \mu \mathrm{L}$, respectivamente do tubo $\mathrm{N}^{0} 1$ ao tubo $\mathrm{N}^{\circ} 6$. A solução de sulfato de cobre no volume de $120 \mu \mathrm{L}$ foi acrescentada, em todos os tubos, no momento de serem incubados a $37^{\circ} \mathrm{C}$. A cinética da reação de oxidação foi continuamente monitorada pelo método de ESTEBAUER e cols. (1992), medindo-se a formação de dienos conjugados através da leitura da Absorbância em 234 nm, utilizando Espectrofotômetro Beckman DU 650, em cubetas de quartz. O intervalo entre as leituras foi de 1 minuto. O tempo total de leitura foi de 200 minutos, as leituras de Absorbância na escala entre 0 e 2. A cinética de oxidação da LDL foi analisada considerando-se os componentes deste processo:

4 "Lag-ime": fase de iniciação, ou seja o tempo requerido para que ocorra o consumo total de antioxidantes de lipoproteínas.

4 "Peak-time": tempo final de oxidação das partículas de lipoproteínas. 


\section{RESULTADOS}

\subsection{Estudo Farmacobotânico}

\subsubsection{Aspecto geral da planta}

Os indivíduos empregados no estudo apresentaram cerca de $3 \mathrm{~m}$ de altura, caule ramificado com diâmetro de até $40 \mathrm{~cm}$ (Fig. 1). Os arbustos, de copa densa, mostravam caule provido de ritidoma acinzentado (Fig. 2), esfoliativo (Fig. 3) e os ramos flexuosos, pubescentes ferrugíneo-acinzentados. As folhas, verdes, papiráceas a subcoriáceas e simples evidenciavam disposição oposta. As flores brancacentas (Fig 4) de pedúnculos unifloros, mostravam numerosos estames, ovário ínfero e estigma capitado. Frutos subglobosos (Fig 5), amareloalaranjados quando maduros, apresentavam 3 a 5 sementes.

\subsubsection{Caracterização macroscópica da droga}

A droga vegetal (Figs. 6 a 7), preparada a partir de folhas de $C$. xanthocarpa apresentou-se subpapirácea a subcoriácea, castanho-esverdeada nas duas faces e lâmina oval, lanceolada, a elíptica. As dimensões das folhas variavam de 7,0 a $14,5 \mathrm{~cm}$ de comprimento por 3,0 a $5,5 \mathrm{~cm}$ de largura, sendo provida de pontoações translúcidas. O ápice mostrou-se agudo a acuminado, a base obtusa e a margem inteira. Pecíolos curvos e canaliculados apresentavam de 7 a $13 \mathrm{~mm}$ de comprimento. A venação mostrou-se peninérvia. A nervura mediana evidenciou-se ligeiramente impressa na face adaxial e proeminente na abaxial; 4 a 7 pares de nervuras laterais, formando ângulos de $55^{\circ} \mathrm{em}$ média com a nervura principal, curvavam-se em direção ao ápice, unindo-se com a nervura marginal.

Os peciolos curvos e canaliculados, de 7 a $13 \mathrm{~mm}$ de comprimento, por 1 a $1,2 \mathrm{~mm}$ de diâmetro, mostravam tricomas tectores curtos principalmente na região das nervuras. 
A droga apresentou a lâmina foliar ondulada principalmente nos bordos (Fig. 7), conservando o odor aromático característico e o sabor amargo.

\subsubsection{Caracterização microscópica da droga}

\subsubsection{Lâmina foliar}

A seção transversal da lâmina foliar, na região do terço mediano inferior, evidenciou mesofilo dorsiventral (Figs. 8 a 13). O parênquima paliçádico apresentou-se constituído de 1 a 3 estratos celulares. Nesta região, observamse, por vezes, amplos idioblastos, que alcançavam cerca de metade da largura dos mesofilos, contendo cristais prismáticos. O parênquima lacunoso mostrou de 5 a 7 camadas de células providas de pequenas projeções, delimitando espaços intercelulares de tamanhos variados. Cristais prismáticos foram observados no parênquimas paliçádico e lacunoso.

A epiderme das faces adaxial e abaxial era constituída de um estrato de células quadrangulares a tabulares, exceto na região das nervuras de menor porte da face adaxial onde, observou-se geralmente duas camadas celulares (Figs. 10)

As células epidérmicas da face abaxial eram proporcionalmente menores que as da face adaxial (Figs. 14 a 18). Os feixes vasculares das nervuras de menor porte por vezes mostraram bainha cristalífera. Nas nervuras de menor porte observaram-se extensões de bainha em direção às faces adaxial e abaxial (Figs. 12 a 13). Cavidades secretoras, de lume delimitado por até 8 células, eram encontradas junto às duas faces (Figs.15 a 18). Estas estruturas secretoras ocorreram em maior proporção na região da nervura mediana e do pecíolo.

As faces adaxial e abaxial, em vista frontal, apresentaram células epidérmicas de paredes periclinais retas a ligeiramente sinuosas, revestidas por cuticula lisa e providas de tricomas tectores unicelulares e cônicos (Figs. 20 a 21). As regiões comissurais das células epidérmicas que recobriam as cavidades secretoras evidenciaram-se retas, curvas ou providas de pequenos dentes (Figs. 
15 a 18). Estas 2 células encontravam-se envolvidas por células dispostas em roseta.

A folha apresentou-se hipoestomática (Figs. 14 a 18). Estômatos paracíticos e anomocíticos foram observados na face abaxial, sendo os mais freqüentes com 4 células subsidiárias. Em secção transversal os estômatos ocorrem ao mesmo nivel das demais células epidérmicas

A nervura mediana (Figs 19 a 21) mostrou contomo plano convexo. Tricomas tectores unicelulares e cônicos foram freqüentes. Em secção transversal, a epiderme apresentou-se constituida de células aproximadamente quadrangulares, de paredes periclinais externas convexas, recobertas por cutícula lisa (Figs. 21 a 22). Em vista frontal, as células epidérmicas exibiram paredes periclinais retas, dispondo-se em fileiras paralelas. Cavidades secretoras ocorreram junto à epiderme (Figs. 25, 27, e 28). O colênquima, constituído de 2 a 3 camadas celulares evidenciou espessamento mais acentuado nos ângulos das células (Fi.g 23). O parênquima fundamental apresentou células aproximadamente isodiamétricas delimitando meatos. Inclusões celulares de oxalato de cálcio, na forma de drusas e de cristais prismáticos, foram encontrados com freqüência nesta região (Figs. 23, 26, e 27).

O feixe vascular bicolateral apresentou-se disposto em arco aberto (Fig. 19). Envolvendo este feixe observaram-se cordões de fibras em determinadas regiões. Os elementos de condução do xilema dispostos radialmente, mostraram-se separados por raios parenquimáticos constituídos de 1 a 2 fileiras de células com paredes lignificadas (Fig. 22). Na região floemática, constituida de seus elementos comuns, encontrou-se grande número de cristais prismáticos (Figs. 22 e 26).

\subsubsection{Peciolo}

A seção transversal da região mediana do peciolo (Figs. 28 a 29), evidenciou células epidérmicas aproximadamente quadrangulares de paredes celulósicas. Estruturas secretoras encontraram-se associadas a este estrato 
celular. Tricomas tectores cônicos unicelulares, semelhantes aos descritos nas nervuras foram observados nesta região. O colênquima mostrou-se constituído de 3 a 5 camadas com espessamento acentuado nos ângulos das células. Cristais prismáticos e drusas foram observados no parênquima fundamental. As drusas foram observadas principalmente nas adjacências do sistema vascular, o qual mostrou-se disposto em arco aberto e envolvido por bainha fibrosa descontínua. Os raios parenquimáticos eram formados de 1 a 2 fileiras de células com paredes espessadas por lignina. 


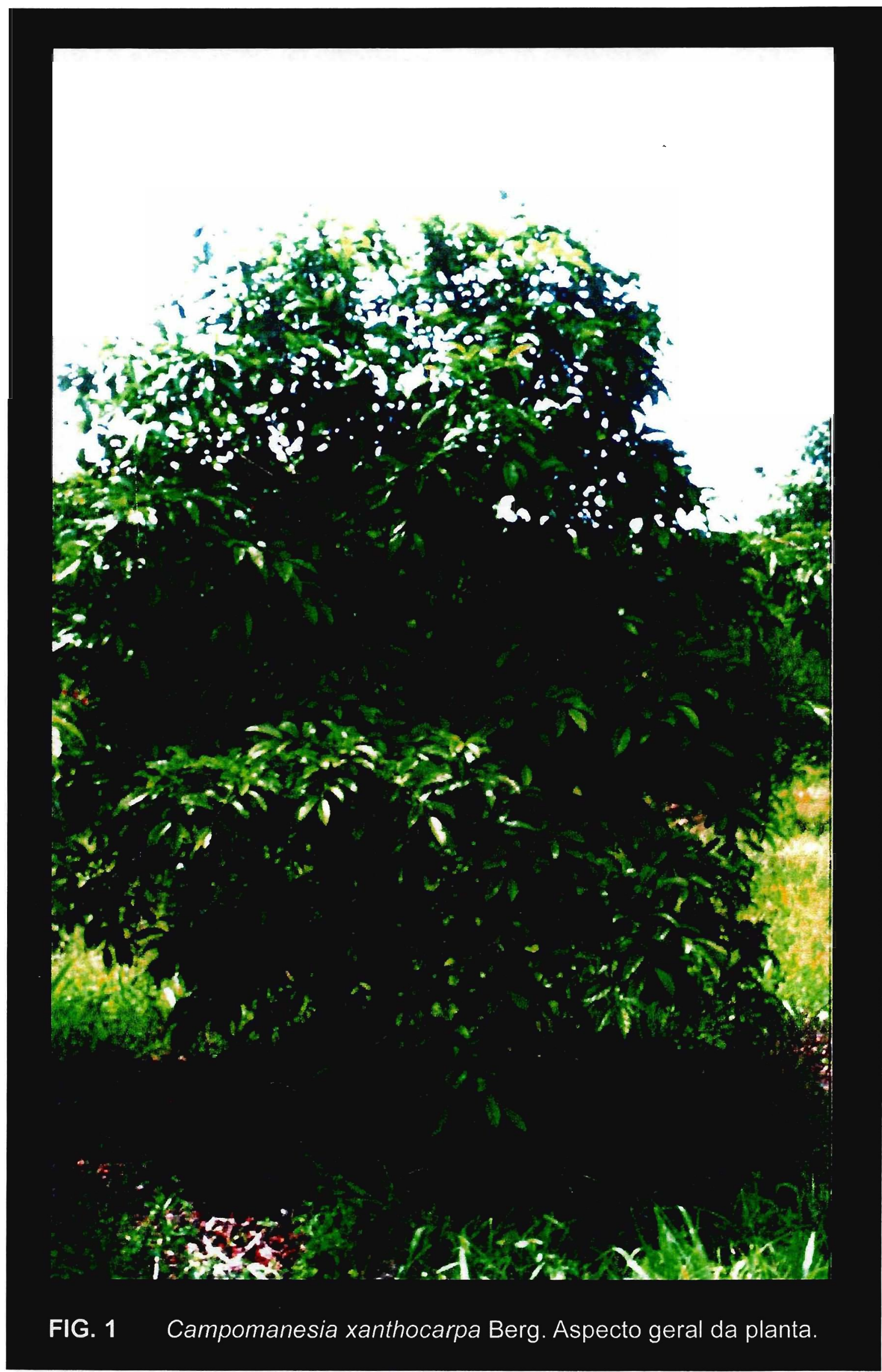




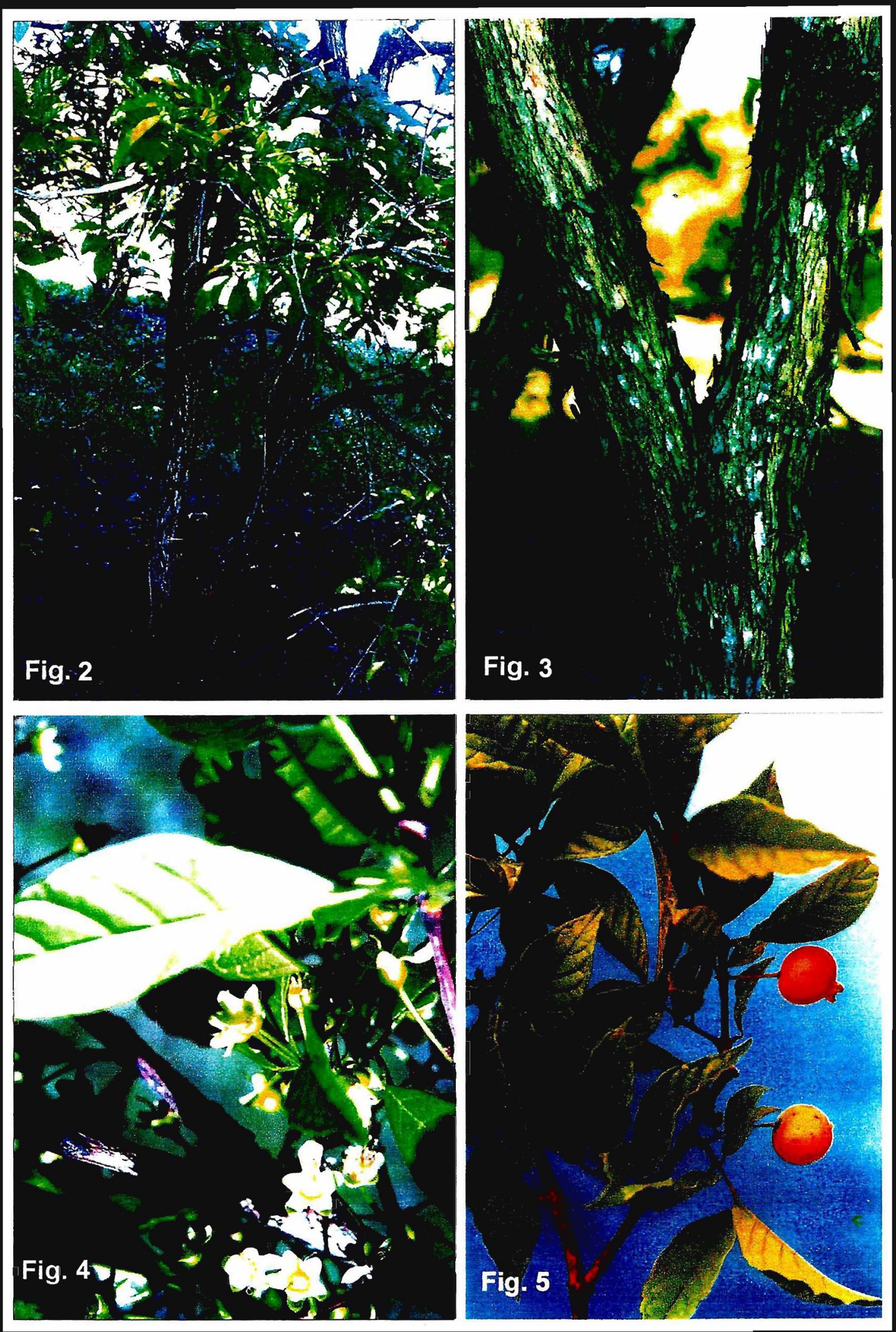



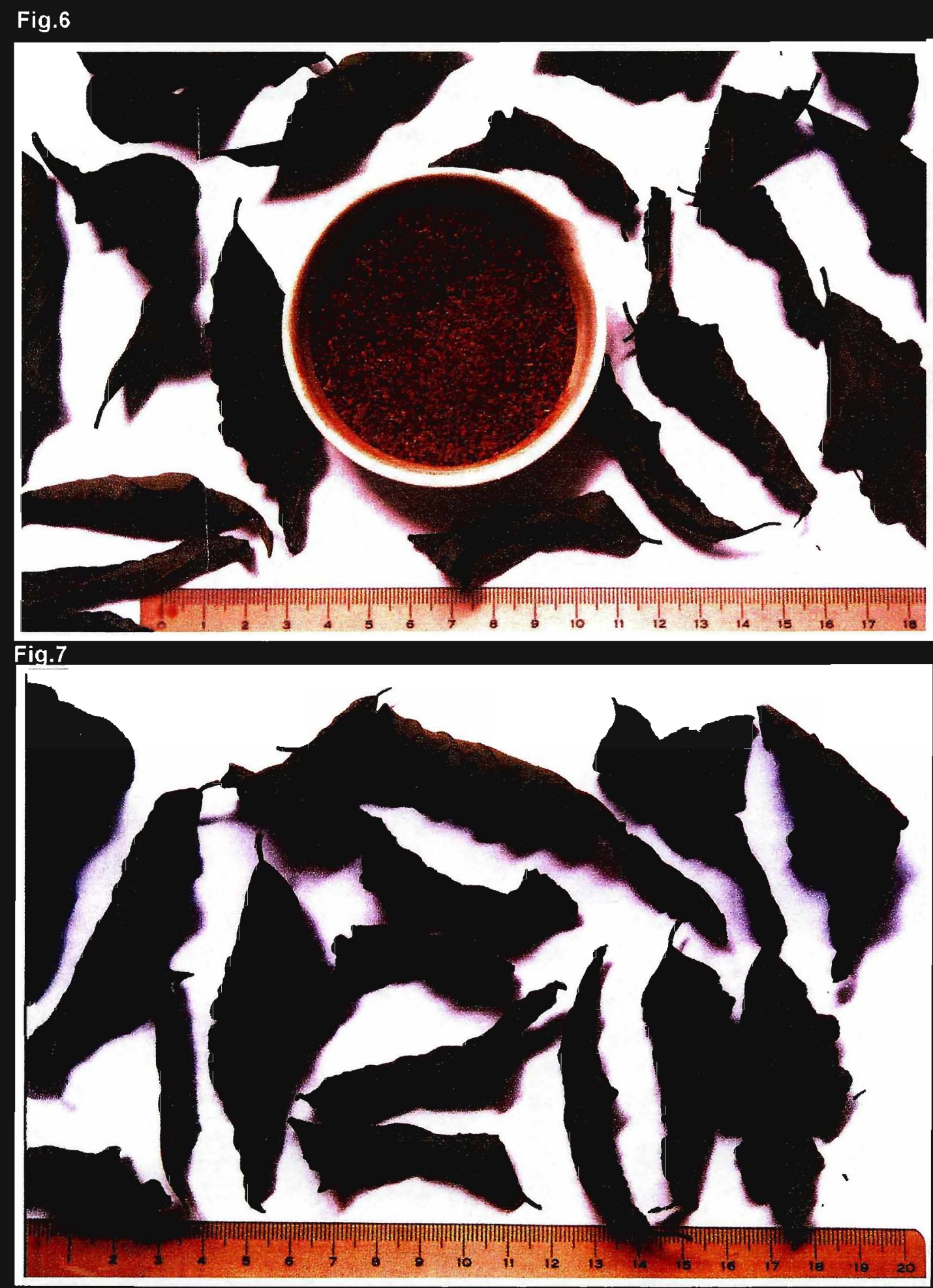

FIG. 6 - Campomanesia xanthocarpa Berg. Droga vegetal constituída de folhas. Droga pulverizada.

FIG. 7 - Campomanesia xanthocarpa Berg. Aspecto geral da folha. 


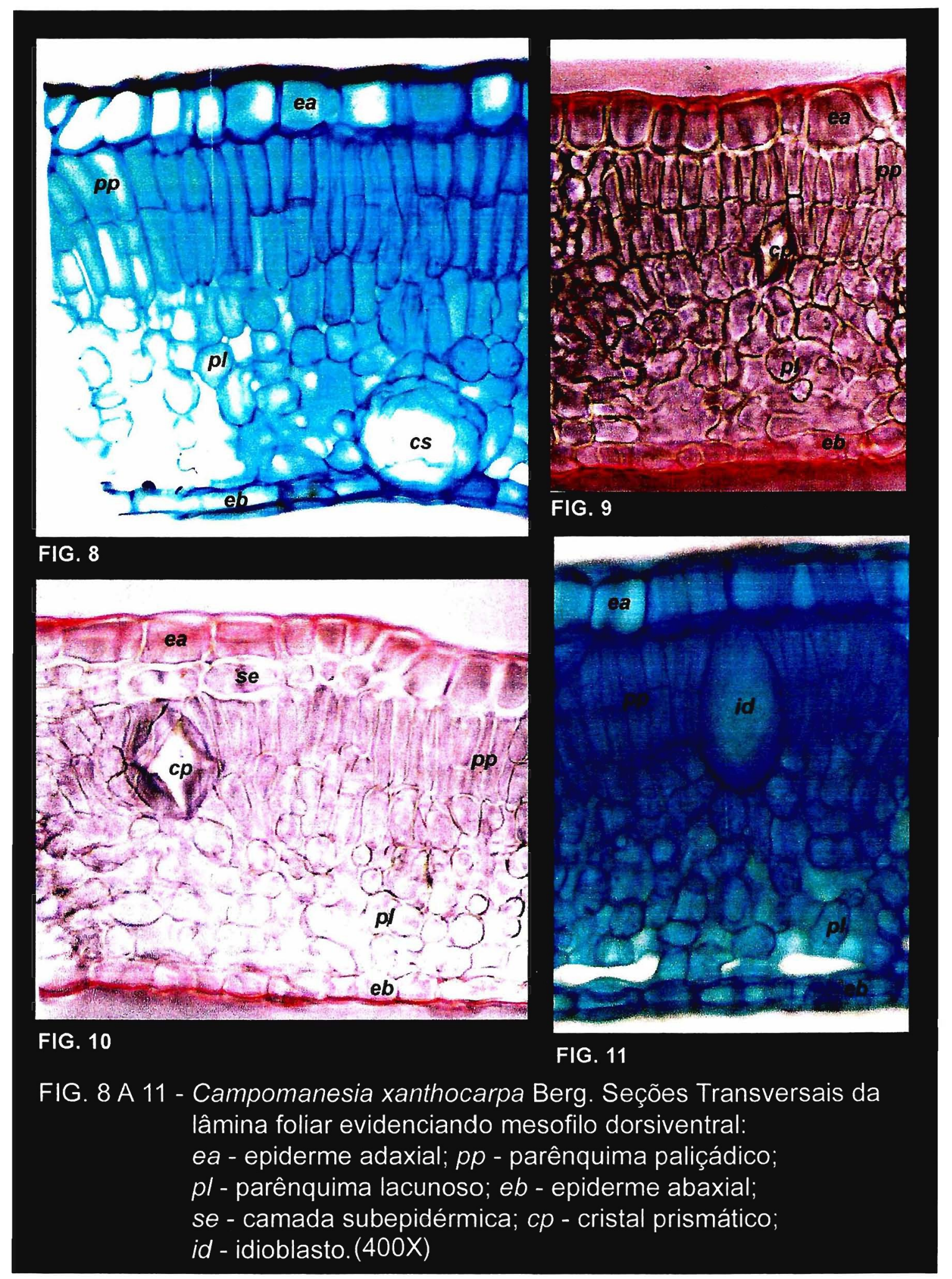


FIG. 12
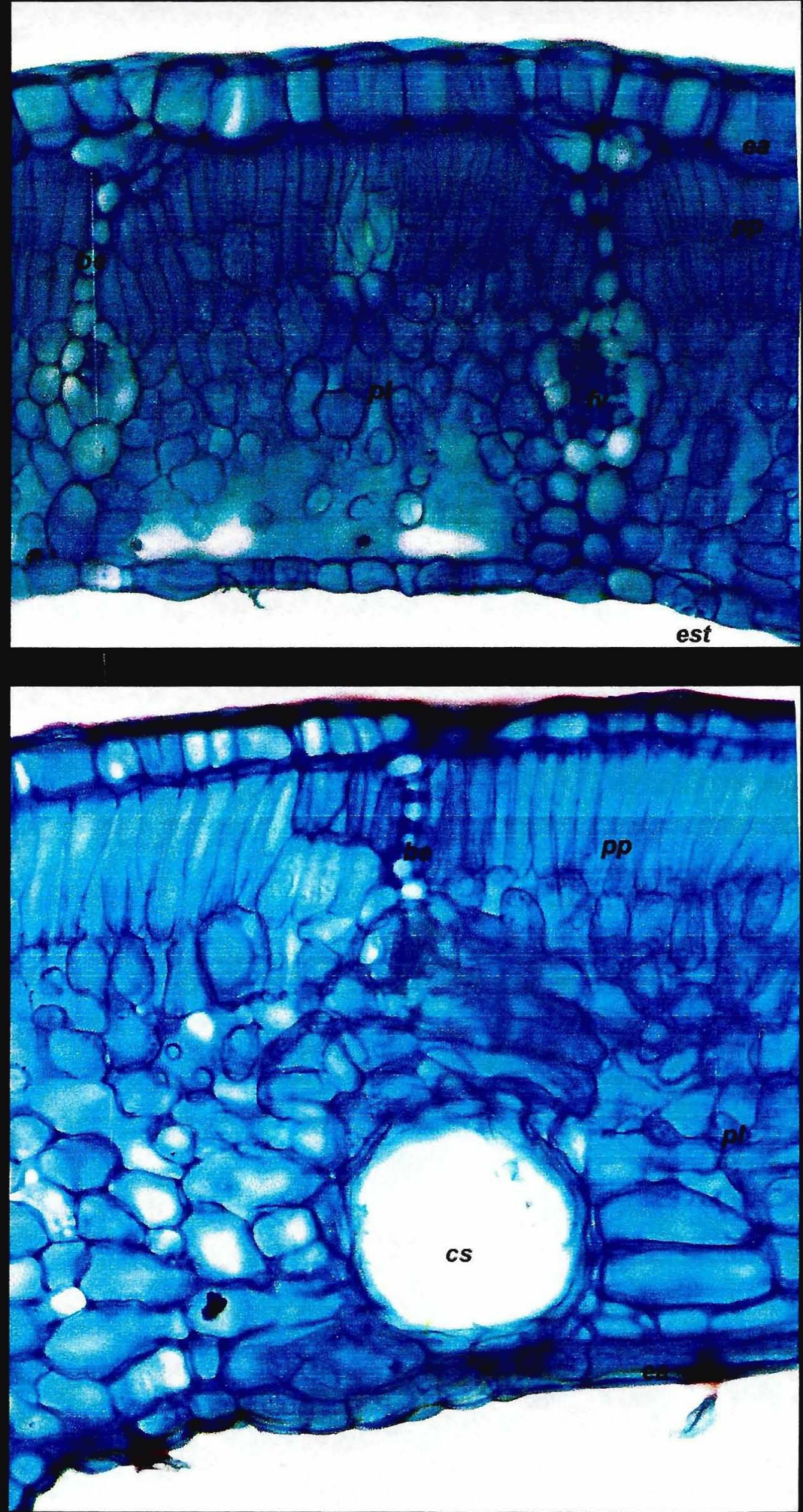

FIG. 13

FIG. 12 A 13 - Campomanesia xanthocarpa Berg. Seções transversais da lâmina foliar evidenciando mesofilo dorsiventral: ea - epiderme adaxial; $p p$ - parênquima paliçádico; pl - parênquima lacunoso; eb - epiderme abaxial; cs - cavidade secretora; be - bainha de extensão; $f v$ - feixe vascular; est - estômato. (400X) 


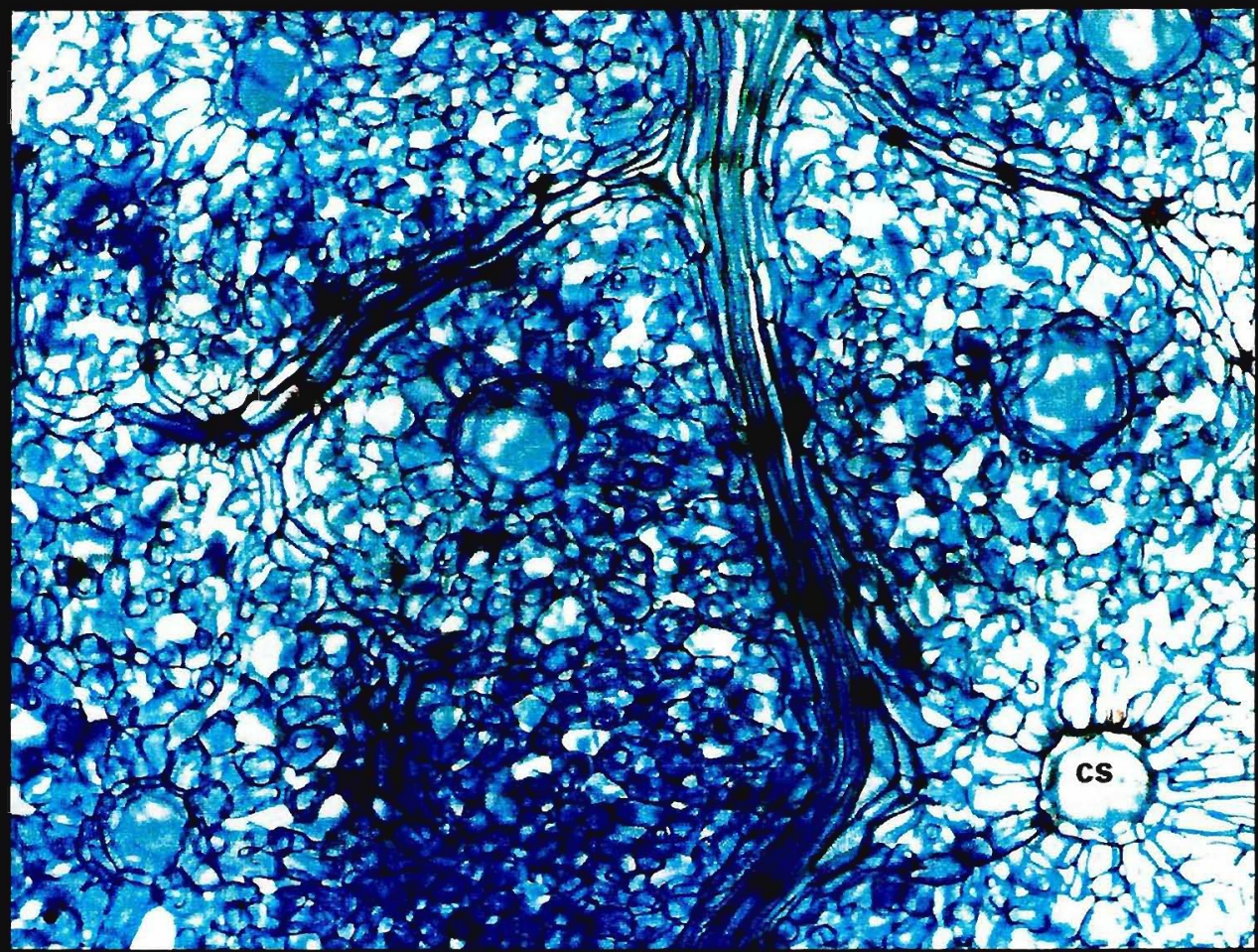

Fig.14

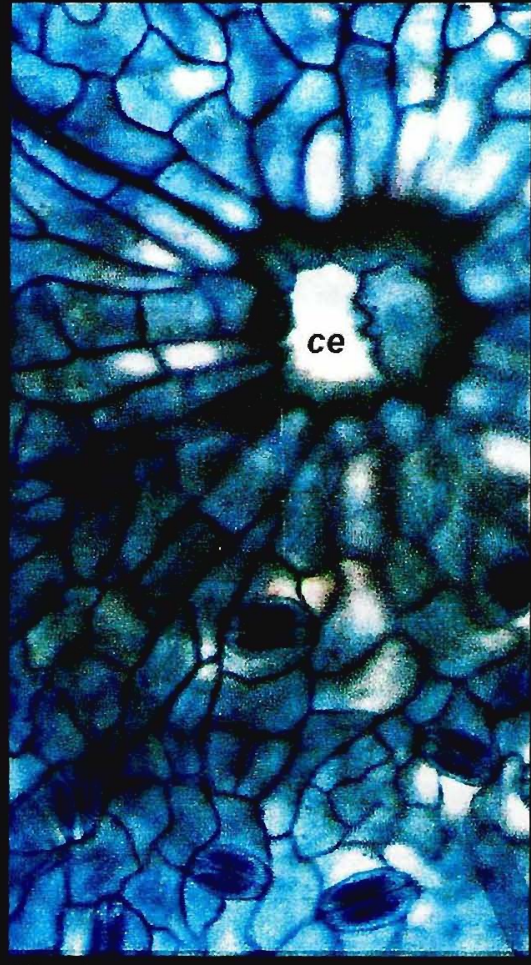

Fig.15

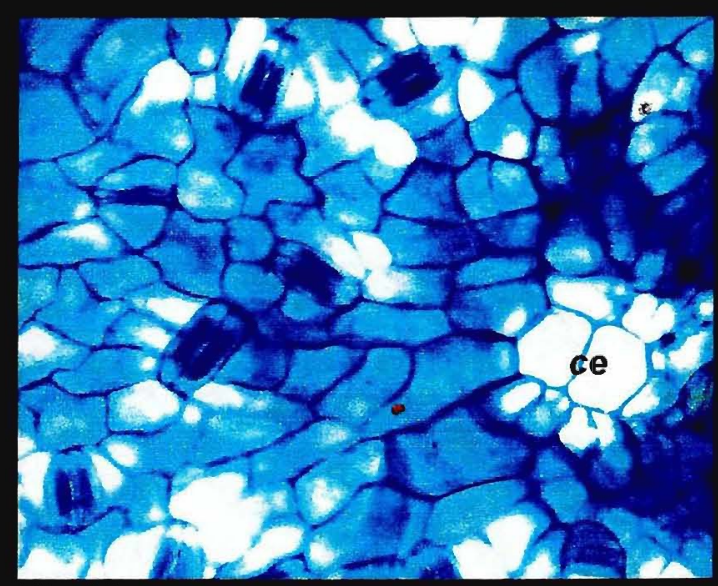

\section{Fig.16}

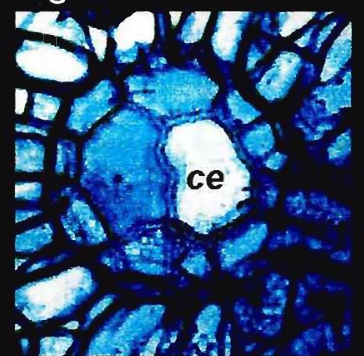

Fig.17

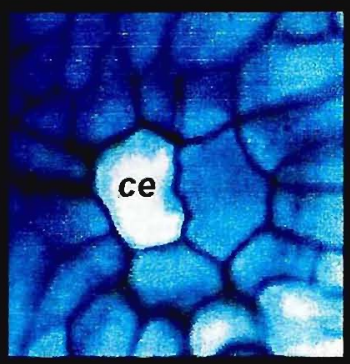

Fig.18

FIG. 14 a 18 - Campomanesia xanthocarpa Berg.

FIG. 14 - Vista frontal da face abaxial; cs - cavidade secretora. (200X) FIG. 15, 16, 17 e 18 - Detalhes da região comissural das células que recobrem as cavidades secretoras; estômatos anomocíticos; ce - células epidérmicas. (400X) 


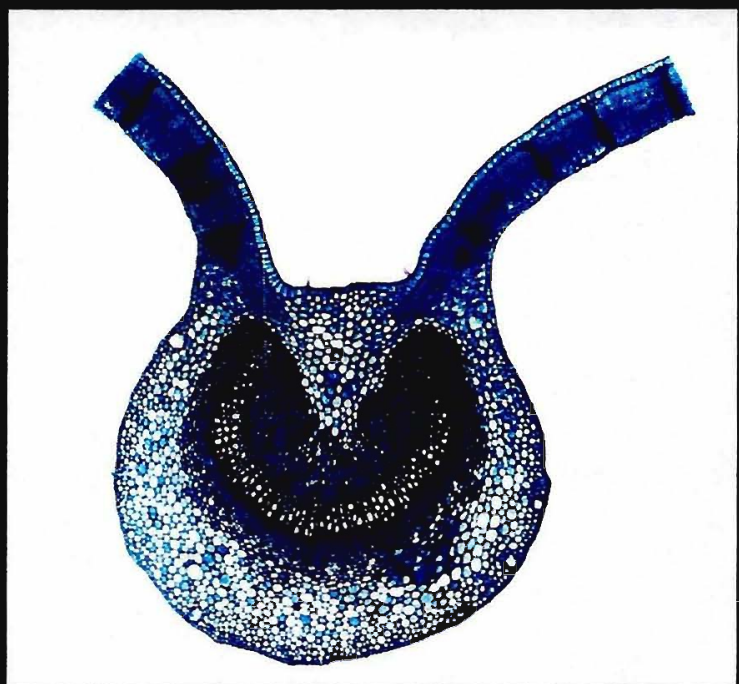

Fig.19

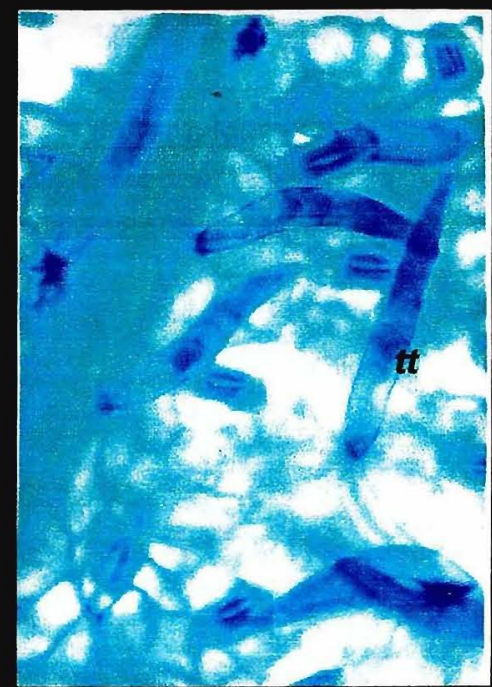

Fig. 20

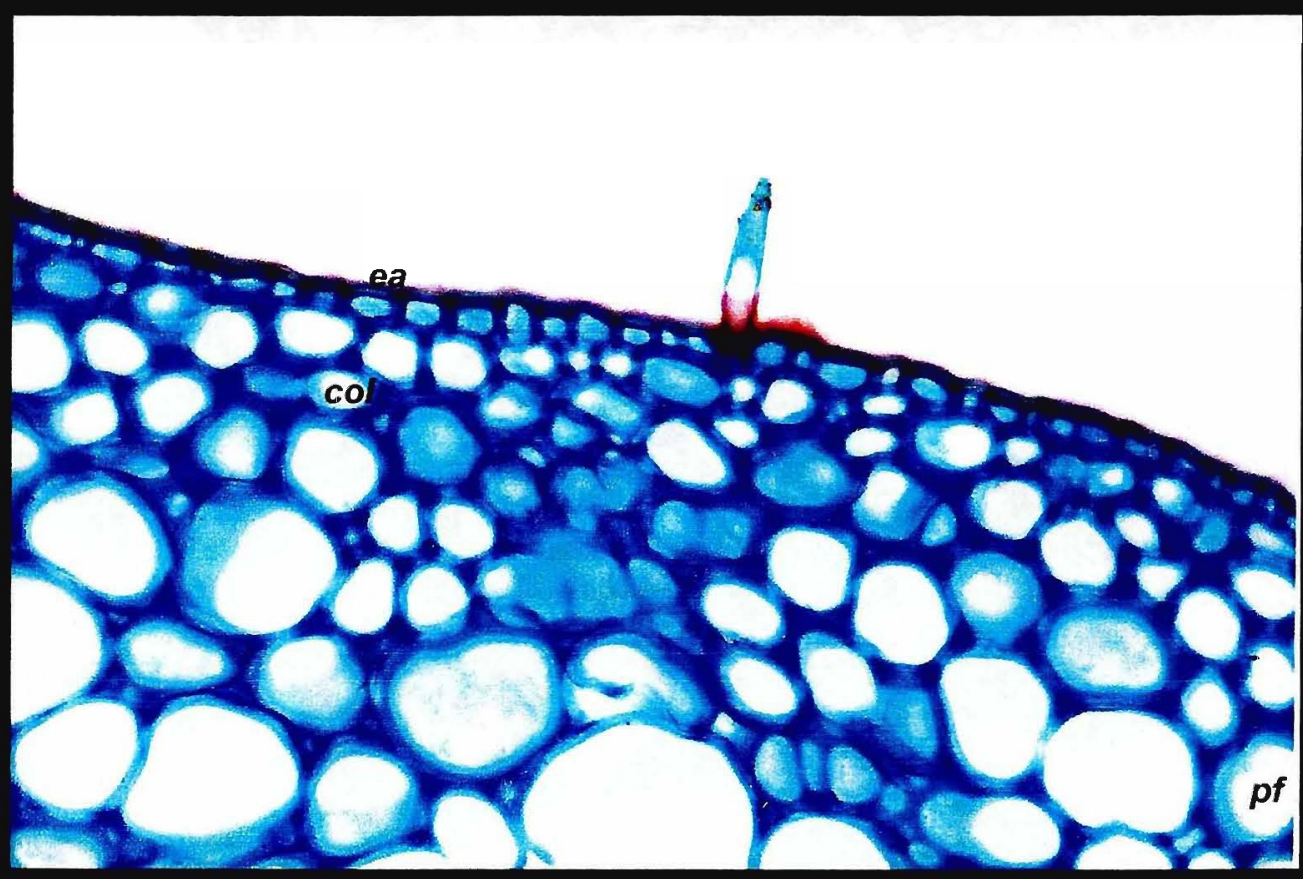

Fig. 21

FIG. 19 a 21 - Campomanesia xanthocarpa Berg.

FIG. 19 - Aspecto geral da seção transversal da nervura mediana. (40X)

FIG. 20 - Vista frontal da face abaxial evidenciando tricomas tectores. (400X) FIG. 21 - Detalhe da nervura; ea - epiderme adaxial; col - colênquima; pf - parênquima fundamental. (400X) 


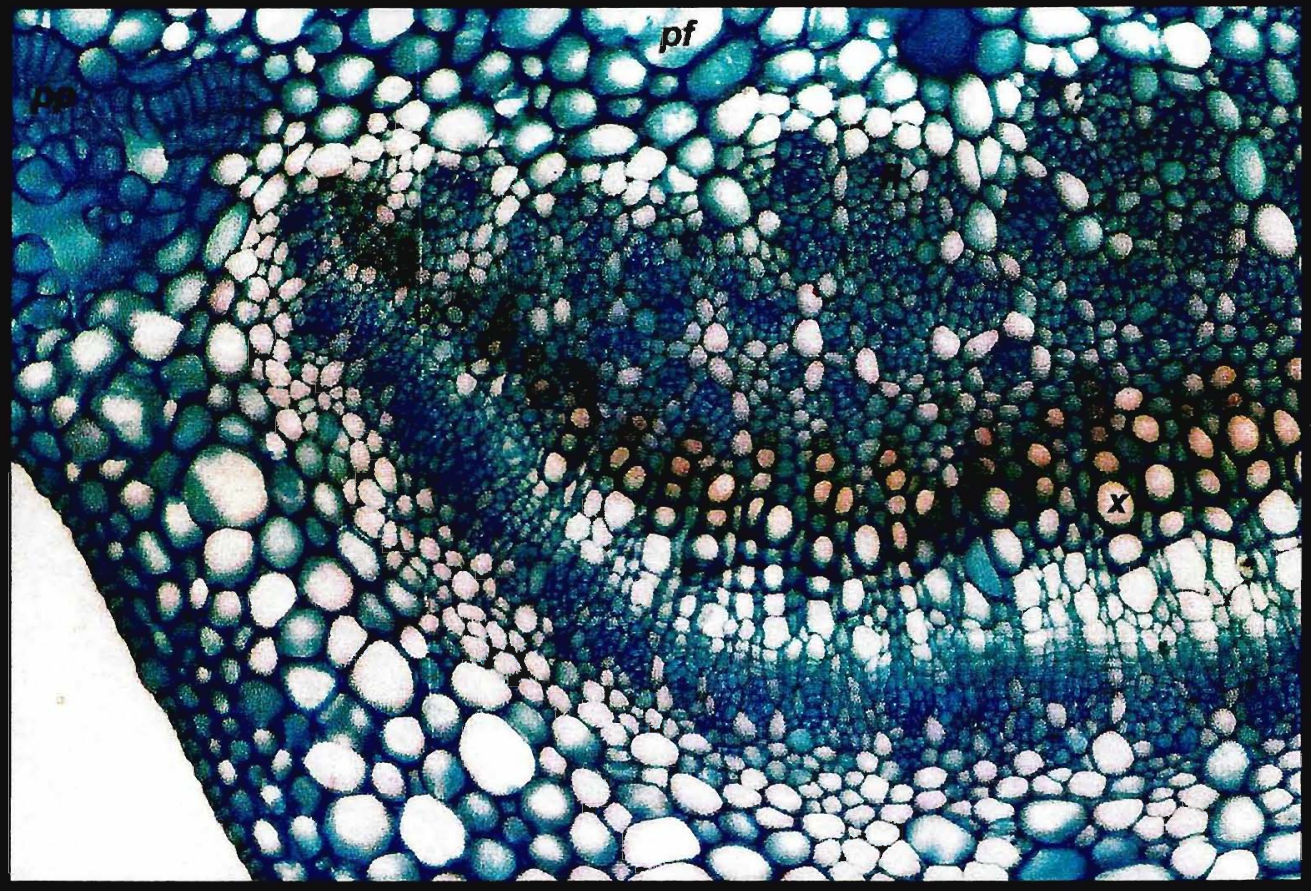

Fig. 22

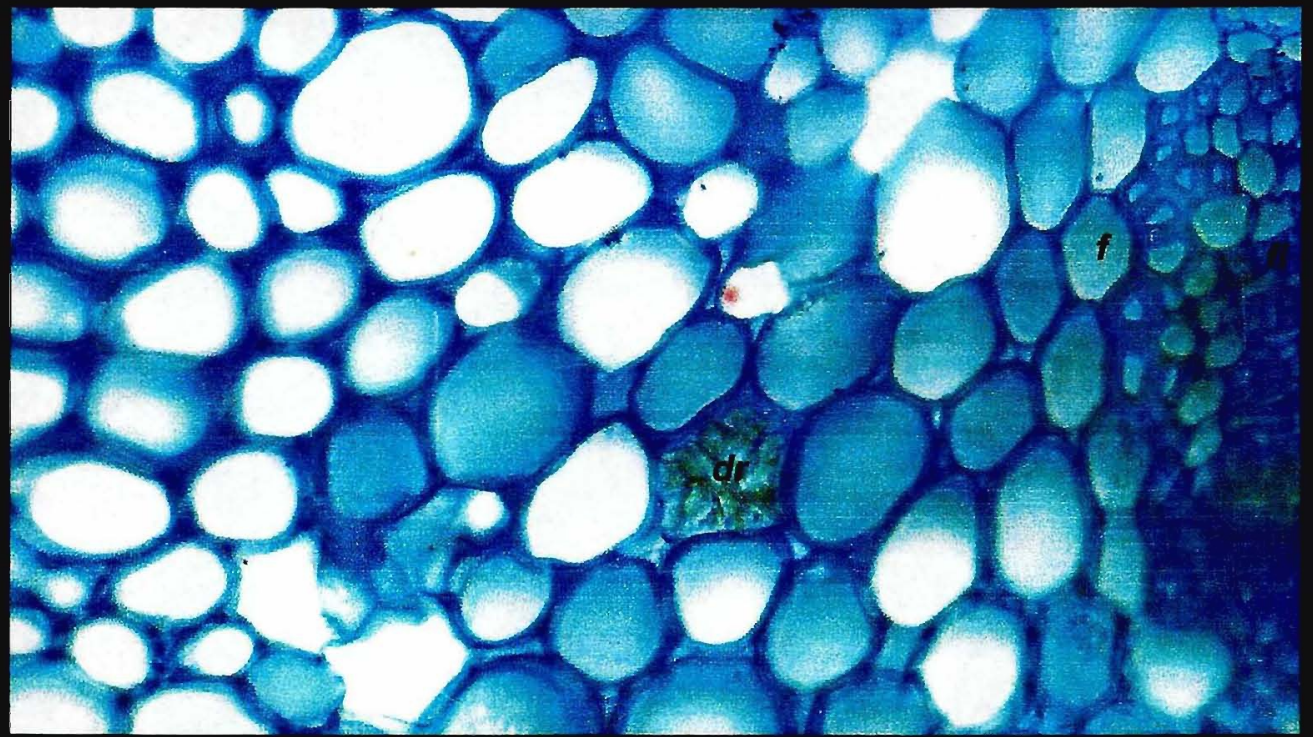

Fig. 23

FIG. 22 a 23 - Campomanesia xanthocarpa Berg. Seções transversais da nervura mediana.

FIG. 22 - Detalhe evidenciando o feixe vascular. (200X)

FIG. 23 - Detalhe destacando uma drusa. (400X)

pp - parênquima paliçádico; pf - parênquima fundamental;

$f l$ - floema; $x$ - xilema; $f$ - fibra; $d r$ - drusa 


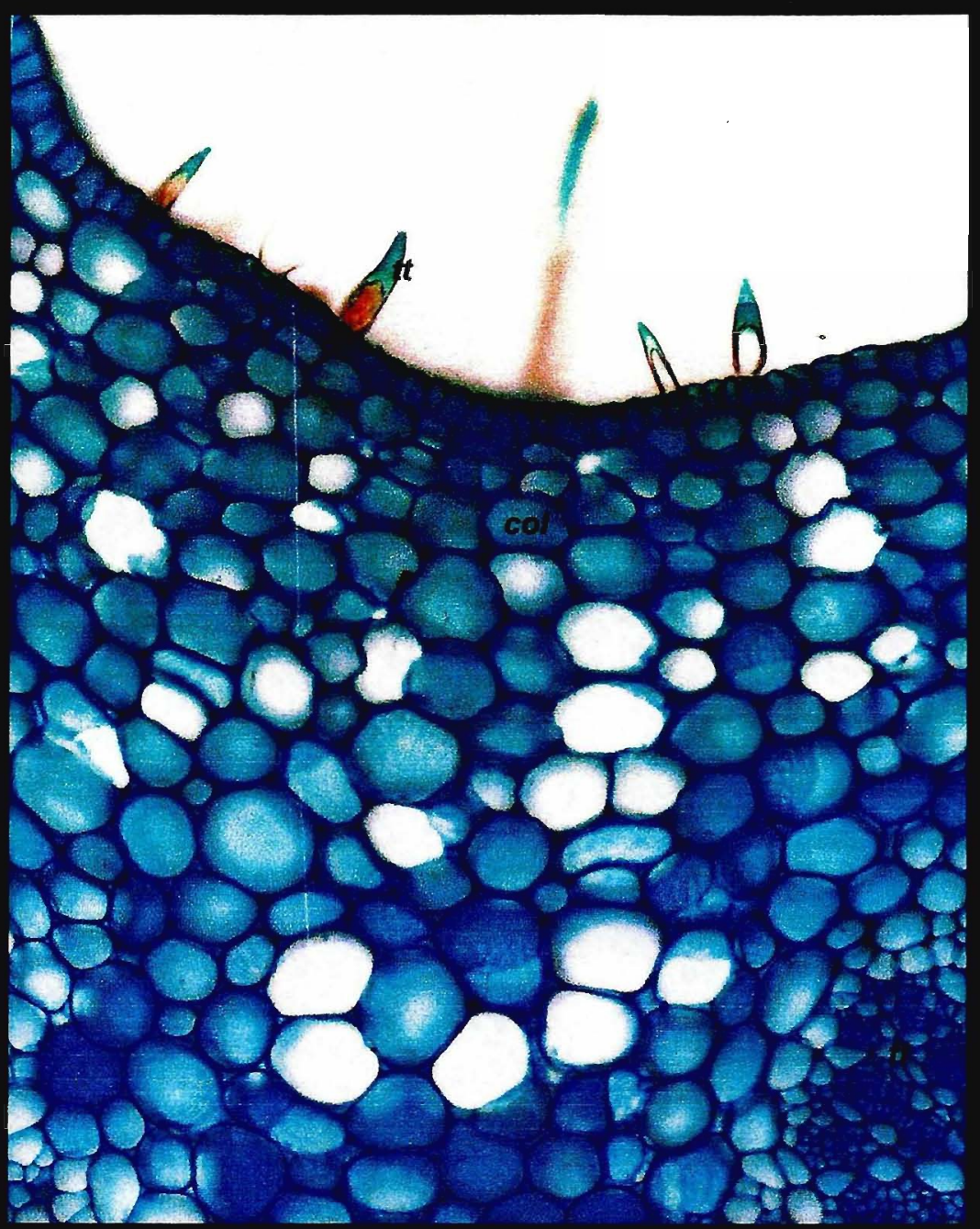

Fig. 24

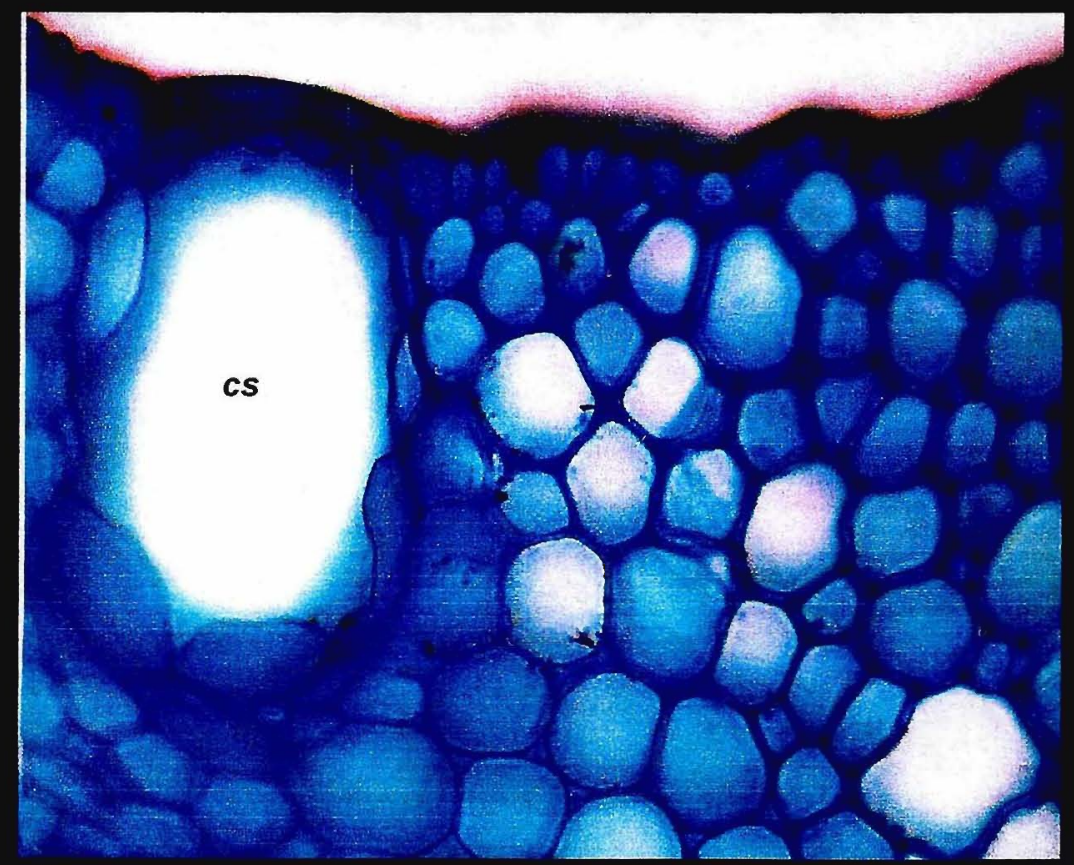

Fig. 25

FIG. 24 a 25 - Campomanesia xanthocarpa Berg. Seções transversais da nervura mediana.

FIG. 24 - Destaque aos tricomas tectores. (200X)

FIG. 25 - Detalhe da cavidade secretora. (400X)

cs - cavidade secretora; $f l$ - floema; col - colênquima; $t t$ - tricomas tectores 


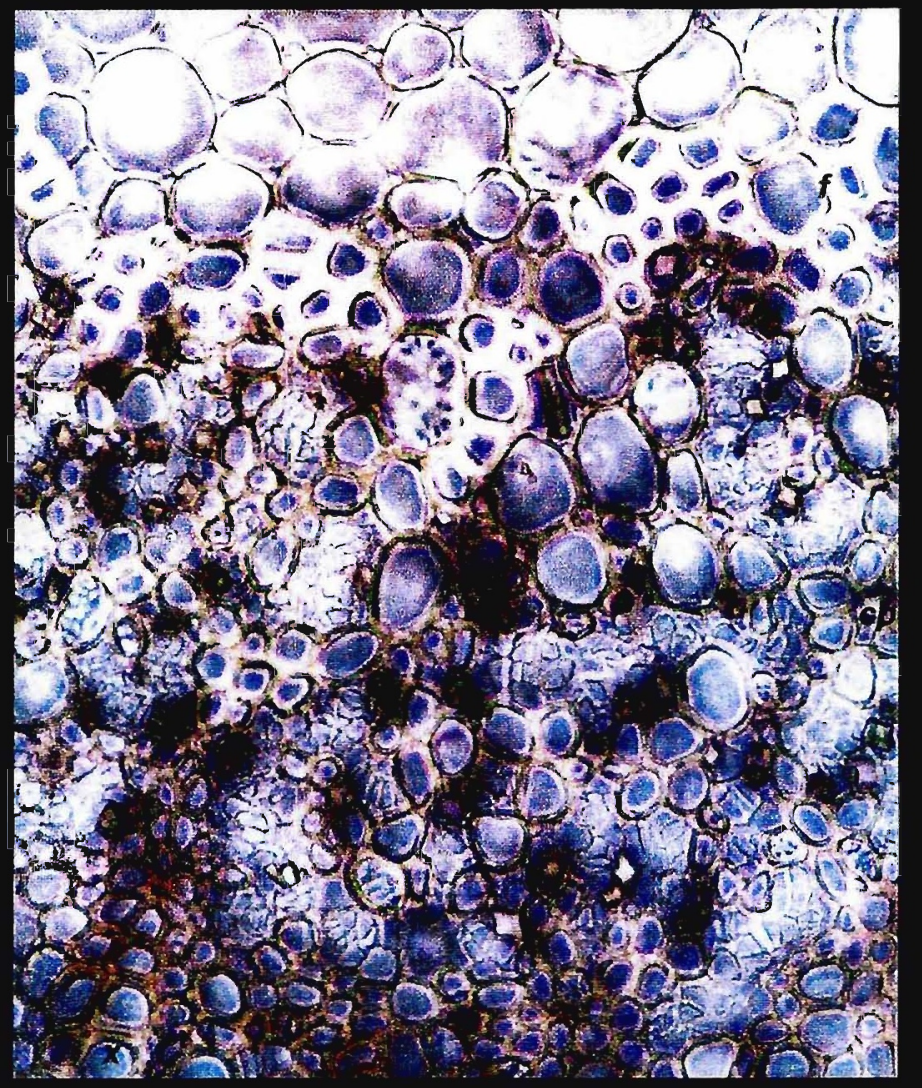

Fig. 26

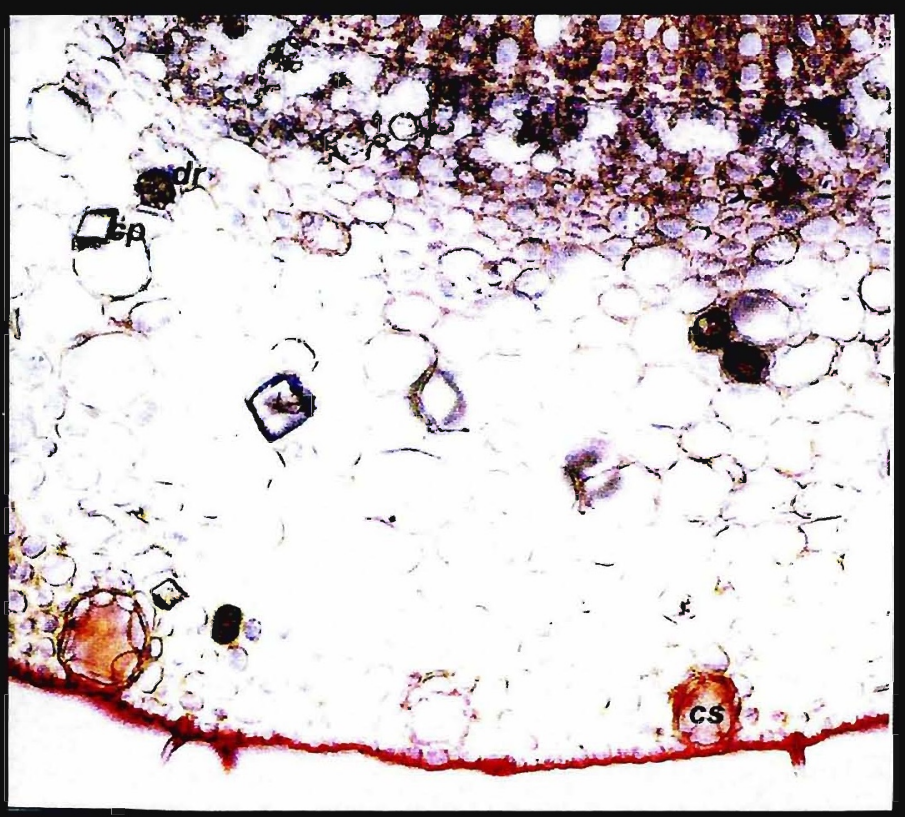

Fig. 27

FIG.26 a 27 - Campomanesia xanthocarpa Berg. Seções transversais da nervura mediana.

FIG. 26 - Detalhe evidenciando cristais prismáticos no floema. (400X)

FIG. 27 - Destaque as cavidades secretoras junto a epiderme abaxial, cristais prismáticos e drusas no parênquima fundamental. (200X) f - fibra; $\mathrm{cp}$ - cristal prismático; cs - cavidade secretora 


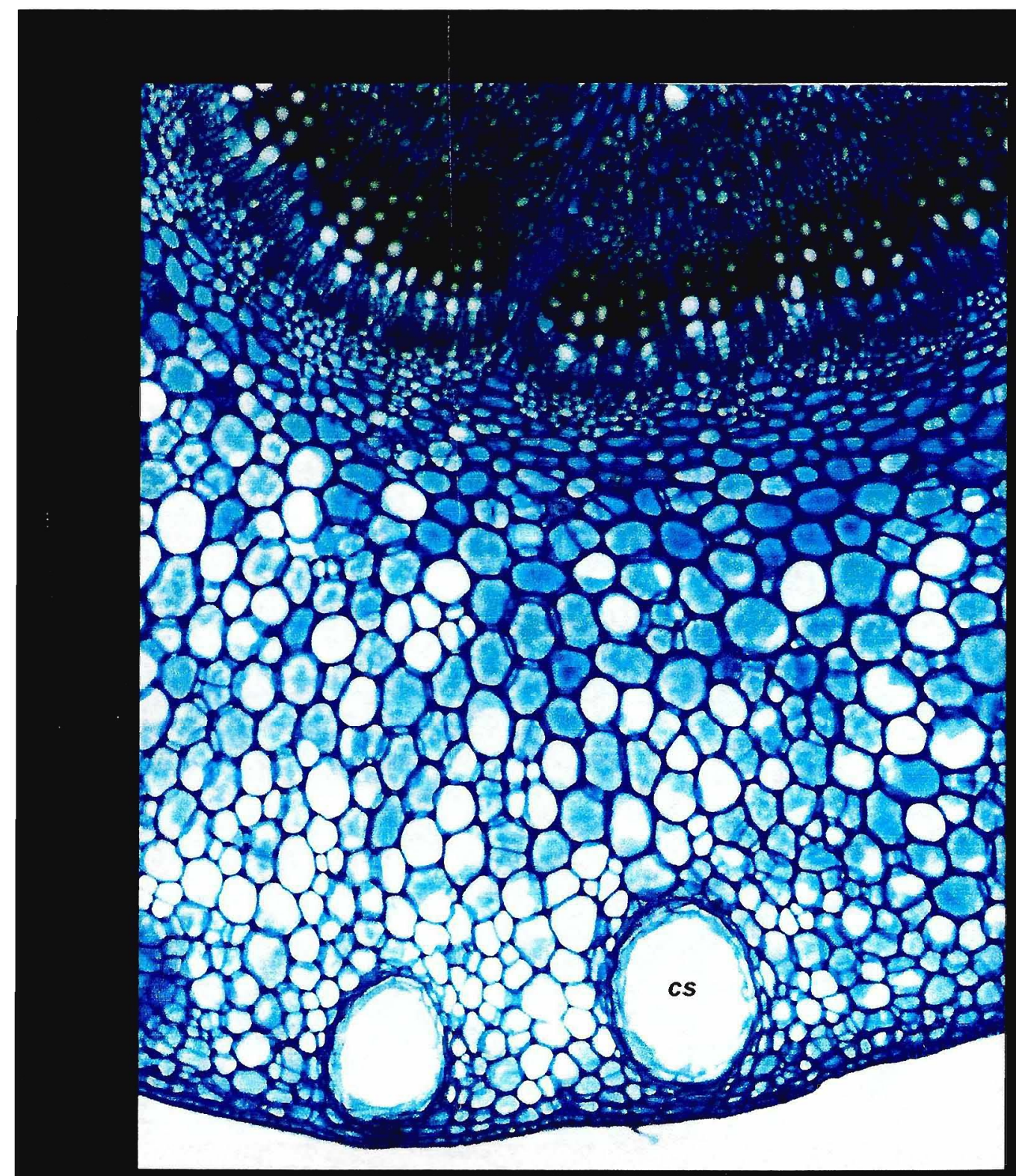

Fig. 28

FIG. 28 - Campomanesia xanthocarpa Berg. Seção transversal evidenciando a cavidade secretora junto a epiderme. (200X) cs - cavidade secretora 


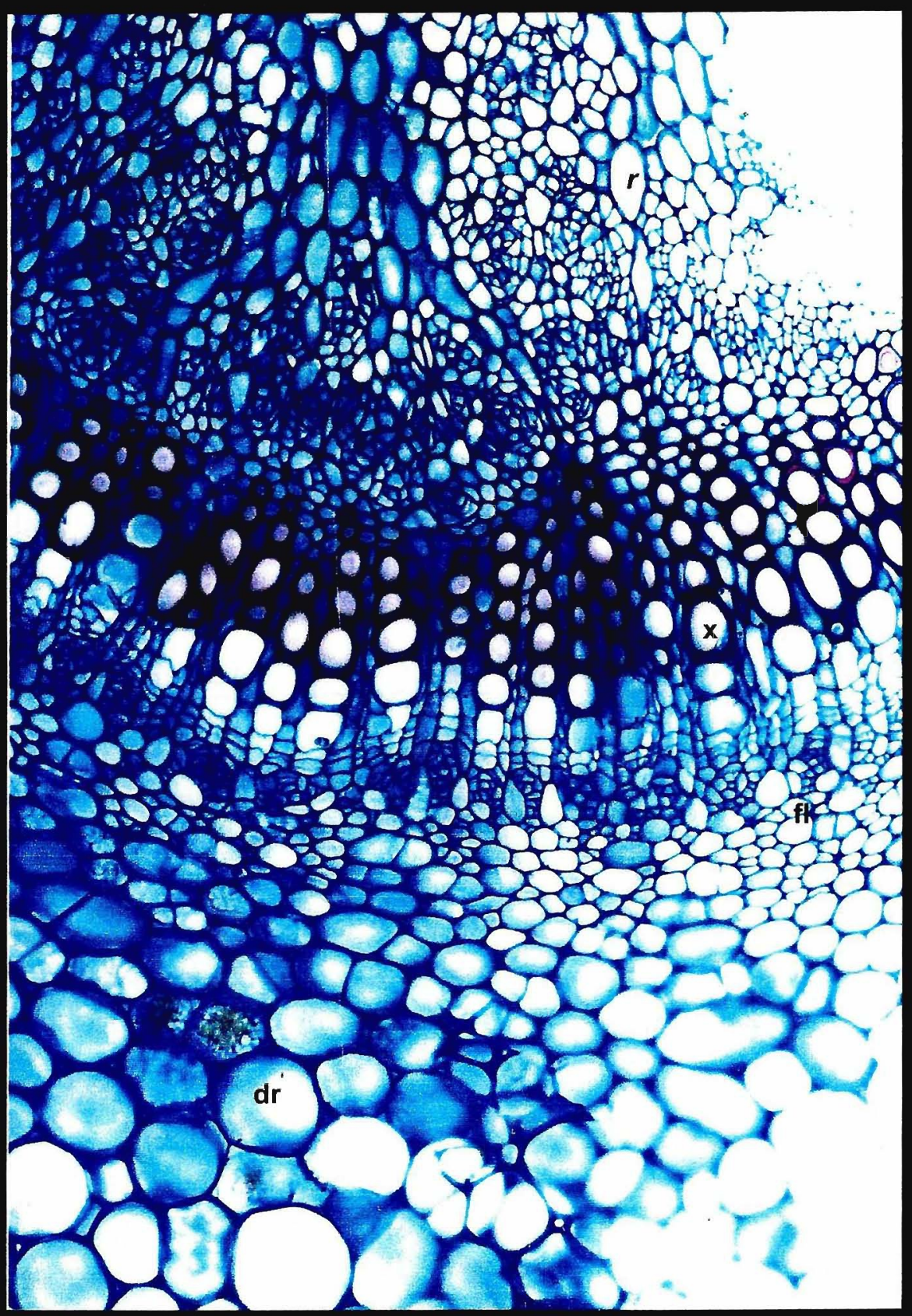

Fig.29

FIG. 29 - Campomanesia xanthocarpa Berg. Seção transversal do pecíolo destacando o feixe vascular bicolateral e drusas. (400X)

fl - floema; $r$ - raio parenquimático; $x$ - vaso do xilema; $d r$ - drusa 


\subsection{Estudo químico}

\subsubsection{Extrato liofilizado (EHA)}

O extrato hidroalcoólico (EHA) apresentou-se como pó castanho escuro e higroscópico. O rendimento do processo extrativo foi $18,2 \%(\mathrm{~m} / \mathrm{m})$

\subsubsection{Triagem fitoquímica}

O resultado da triagem fitoquímica realizada com a droga vegetal pulverizada e com o extrato liofilizado EHA encontra-se na tabela 3.

Tabela.3. Triagem fitoquímica da droga vegetal e do extrato hidroalcoólico EHA preparado a partir de folhas de C. xanthocarpa.

\begin{tabular}{|c|c|c|}
\hline $\begin{array}{c}\text { Grupo de } \\
\text { substâncias/reativos }\end{array}$ & $\begin{array}{l}\text { Droga } \\
\text { vegetal }\end{array}$ & $\begin{array}{c}\text { Extrato } \\
\text { hidroalcoólico (EHA) }\end{array}$ \\
\hline $\begin{array}{l}\text { ALCALÓIDES: } \\
\text { - Reativo de Bertrand } \\
\text { - Reativo de Bouchardat } \\
\text { - Reativo de Dragendorff } \\
\text { - Reativo de Mayer }\end{array}$ & $\begin{array}{l}\text { Negativo } \\
\text { Negativo } \\
\text { Negativo } \\
\text { Negativo }\end{array}$ & $\begin{array}{l}\text { Negativo } \\
\text { Negativo } \\
\text { Negativo } \\
\text { Negativo }\end{array}$ \\
\hline $\begin{array}{l}\text { ANTRAQUINONAS: } \\
\text { - Reação de Borntraeger }\end{array}$ & Negativo & Negativo \\
\hline $\begin{array}{l}\text { GLICOSIDEOS } \\
\text { CARDIOTÔNICOS } \\
\text { - Reação de Liebermann- } \\
\text { Burchardt }\end{array}$ & Positivo & Positivo \\
\hline $\begin{array}{l}\text { - Reação de Baljet } \\
\text { - Reação de Kedde } \\
\text { - Reação de Keller-Killiani }\end{array}$ & $\begin{array}{l}\text { Negativo } \\
\text { negativo } \\
\text { negativo }\end{array}$ & $\begin{array}{l}\text { Negativo } \\
\text { Negativo } \\
\text { negativo }\end{array}$ \\
\hline $\begin{array}{l}\text { FLAVONÒÍDES } \\
\text { - Reação com tricloreto de } \\
\text { alumínio } \\
\text { - Reação de Shinoda } \\
\text { - Reação com hidróxidos } \\
\text { alcalinos }\end{array}$ & $\begin{array}{l}\text { Positivo } \\
\text { Positivo } \\
\text { Positivo }\end{array}$ & $\begin{array}{l}\text { Positivo } \\
\text { Positivo } \\
\text { Positivo }\end{array}$ \\
\hline
\end{tabular}




\begin{tabular}{|c|c|c|}
\hline $\begin{array}{c}\text { Grupo de } \\
\text { substâncias/reativos }\end{array}$ & $\begin{array}{l}\text { Droga } \\
\text { Vegetal }\end{array}$ & $\begin{array}{c}\text { Extrato } \\
\text { Hidroalcoólico } \\
\text { (EHA) }\end{array}$ \\
\hline $\begin{array}{l}\text { ÓLEOS ESSENCIAIS } \\
\text { - Teste organoléptico } \\
\text { - Microdestilação/Sudam III }\end{array}$ & $\begin{array}{l}\text { Positivo } \\
\text { Positivo }\end{array}$ & $\overline{-}$ \\
\hline $\begin{array}{l}\text { SAPONINAS } \\
\text { - Espuma persistente } \\
\text { - Índice de espuma } \\
\text { - Hemólise }\end{array}$ & $\begin{array}{l}\text { Positiva } \\
400 \\
\text { negativa }\end{array}$ & $\begin{array}{l}\text { Positiva } \\
1800 \\
\text { negativa }\end{array}$ \\
\hline $\begin{array}{l}\text { TANINOS } \\
\text { - Adstringência } \\
\text { - Reação com cloreto férrico } \\
\text { - Reação com acetato de cobre }\end{array}$ & $\begin{array}{l}\text { Positivo } \\
\text { Positivo } \\
\text { Positivo } \\
\text { (precipitado marrom } \\
\text { claro) }\end{array}$ & $\begin{array}{c}\text { Positivo } \\
\text { Positivo } \\
\text { Positivo } \\
\text { (precipitado marrom } \\
\text { claro) }\end{array}$ \\
\hline $\begin{array}{l}\text { - Reação com acetato de } \\
\text { chumbo }\end{array}$ & $\begin{array}{l}\text { Positivo } \\
\text { (precipitado marrom } \\
\text { claro) }\end{array}$ & $\begin{array}{c}\text { Positivo } \\
\text { (precipitado marrom } \\
\text { claro) }\end{array}$ \\
\hline $\begin{array}{l}\text { • Reação com solução de } \\
\text { alcaloide }\end{array}$ & $\begin{array}{c}\text { Positivo } \\
\text { (precipitado branco) }\end{array}$ & $\begin{array}{c}\text { Positivo } \\
\text { (precipitado branco) }\end{array}$ \\
\hline - Reação com gelatina & $\begin{array}{c}\text { Positivo } \\
\text { (precipitado branco) }\end{array}$ & $\begin{array}{c}\text { Positivo } \\
\text { (precipitado branco) }\end{array}$ \\
\hline
\end{tabular}

\subsubsection{Análise cromatográfica em camada delgada da droga e do} extrato EHA

Os resultados da análise cromatográfica em camada delgada da droga e do extrato EHA encontram-se nas tabelas 4, 5, 6, 7 e 8 . 
Tabela 4. Análise cromatográfica em camada delgada (Sistema 1) dos extratos metanólicos a $0,2 \%$ da droga vegetal, do extrato EHA de $C$. xanthocarpa e da substância química de referência (SQR) saponina Merck® a $0,05 \%$.

\begin{tabular}{cccclc}
\hline \hline $\begin{array}{c}\text { Droga } \\
\text { Vegetal }\end{array}$ & EHA & SQR & Cor & Forma & hRf \\
& & & & & \\
+ & + & - & rosa & arredondada & 15 \\
++ & +++ & - & roxo & arredondada & 20 \\
++ & +++ & - & amarelo & arredondada & 22 \\
& & & claro & & \\
++ & +++ & roxo & arredondada & 45 \\
+++ & +++ & Saponina & rosa & arredondada & 50 \\
++ & ++ & - & roxo & arredonda & 60 \\
+ & ++ & - & roxo & arredondada & 81 \\
\hline \hline
\end{tabular}

Intensidades: $(-)$ - ausente; $(+)$ - fraca; $(++)$ - média; $(+++)-$ forte 
Tabela 5. Análise cromatográfica em camada delgada (Sistema 2) dos extratos metanólicos a $0,2 \%$ da droga vegetal, do extrato EHA de C. xanthocarpa e das soluções metanólicas a 0,05\% das substâncias químicas de referência (SQR)- quercetina, rutina, apigenina, crisina e ácido clorogênico.

\begin{tabular}{|c|c|c|c|c|c|}
\hline $\begin{array}{l}\text { Droga } \\
\text { Vegetal }\end{array}$ & EHA & SQR & Cor & Forma & hRf \\
\hline+ & ++ & - & Vermelha & arredondada & 8 \\
\hline++ & +++ & - & roxo & arredondada & 34 \\
\hline- & - & Rutina +++ & Castanho & arredondada & 6 \\
\hline- & - & Quercetina +++ & roxo & arredondada & 54 \\
\hline- & - & Crisina +++ & roxo & arredondada & 70 \\
\hline- & - & Apigenina +++ & roxo & Arredondada & 60 \\
\hline- & - & $\begin{array}{c}\text { Ac. Clorogênico } \\
+++\end{array}$ & roxo & arredondada & 80 \\
\hline
\end{tabular}

Intensidades: $(-)$ - ausente; $(+)-$ fraca; $(++)$ - média; $(+++)-$ forte. 
Tabela 6. Análise cromatográfica em camada delgada (Sistema 3) dos extratos metanólicos a $0,2 \%$ da droga vegetal, do extrato EHA de C. xanthocarpa e das. soluções metanólicas a 0,05\% das substâncias químicas de referência (SQR) - quercetina, rutina, e ácido clorogênico.

\begin{tabular}{|c|c|c|c|c|c|}
\hline $\begin{array}{l}\text { Droga } \\
\text { Vegetal }\end{array}$ & EHA & SQR & Cor & Forma & hRf \\
\hline++ & +++ & - & Amarelo escuro & arredondada & 61 \\
\hline++ & +++ & - & Amarelo escuro & arredondada & 74 \\
\hline++ & +++ & - & Amarelo escuro & arredondada & 83 \\
\hline++ & +++ & - & Marrom claro & arredondada & 92 \\
\hline++ & +++ & - & Marrom claro & arredondada & 97 \\
\hline- & - & quercetina+++ & amarela & Arredondada & 99 \\
\hline- & - & Rutina +++ & Amarelo claro & arredondada & 13 \\
\hline- & - & $\begin{array}{c}\text { Ac. Clorogênico } \\
+++\end{array}$ & Marrom claro & arredondada & 41 \\
\hline
\end{tabular}

Intensidades: $(-)$ - ausente; $(+)-$ fraca; $(++)-$ média; $(+++)-$ forte. 
Tabela 7. Análise cromatográfica em camada delgada (Sistema 4) das soluções clorofórmicas a $1 \%$ do óleo essencial das folhas frescas de $C$. xanthocarpa e das substâncias químicas de referência (SQR) - linalol e acetato de linalina.

\begin{tabular}{|c|c|c|c|c|}
\hline $\begin{array}{l}\text { Óleo } \\
\text { essencial }\end{array}$ & SQR & Cor & Forma & hRf \\
\hline o. e. +++ & - & Vermelha azulada & arredondada & 35 \\
\hline o. e. +++ & linalol. +++ & vermelha & arredondada & 46,5 \\
\hline o. e. +++ & - & vermelha & arredondada & 62 \\
\hline o. e. +++ & $\begin{array}{l}\text { Acetato de } \\
\text { linalila. +++ }\end{array}$ & vermelha & arredondada & 70 \\
\hline o. e. +++ & - & roxa & arredondada & 77 \\
\hline
\end{tabular}

Intensidades: $(-)$ - ausente; $(+)-$ fraca; $(++)$ - média; $(+++)$ - forte. 
Tabela 8. Análise cromatográfica em camada delgada (Sistema 5) das soluções clorofórmicas a $1 \%$ do óleo essencial das folhas de C. xanthocarpa e das substâncias químicas de referência (SQR): linalol e acetato de linalina.

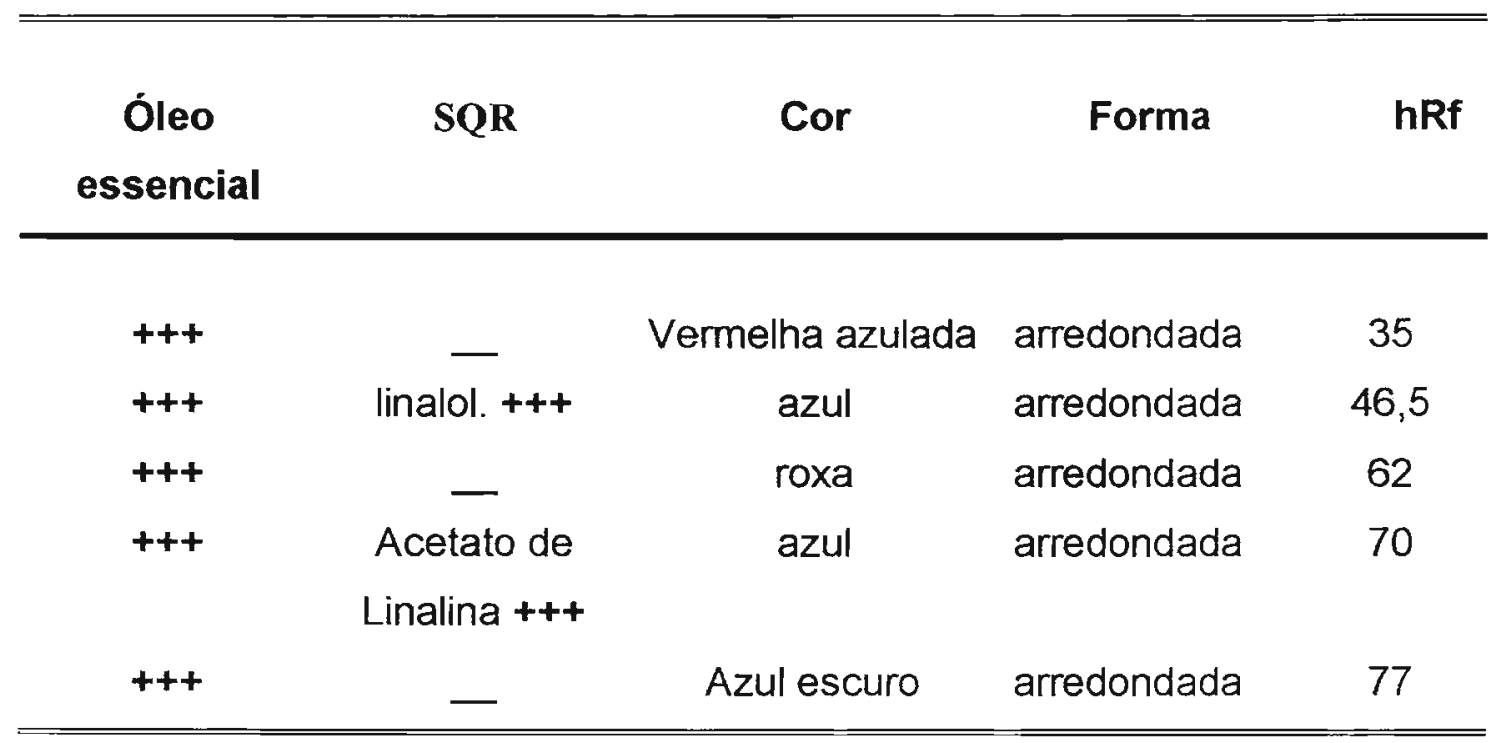

Intensidades: $(-)$ - ausente; $(+)-$ fraca; $(++)$ - média; $(+++)-$ forte.

\subsubsection{Teor de taninos}

A determinação do teor de taninos foi realizada segundo metodologia descrita na FARMACOPÉIA EUROPEIA (2001). A linearidade do método foi determinada nas concentrações de $0,5012 \mu \mathrm{g} / \mathrm{mL}$ a $2,0048 \mu \mathrm{g} / \mathrm{mL}$ da substância química de referência pirogalol ( $101 \%$ de pureza) Merck®. O teor de taninos foi calculado através da equação da reta. 
Figura 30. Curva padrão da substância química de referência pirogalol, linearidade da curva, limite de confiança superior e limite de confiança inferior.

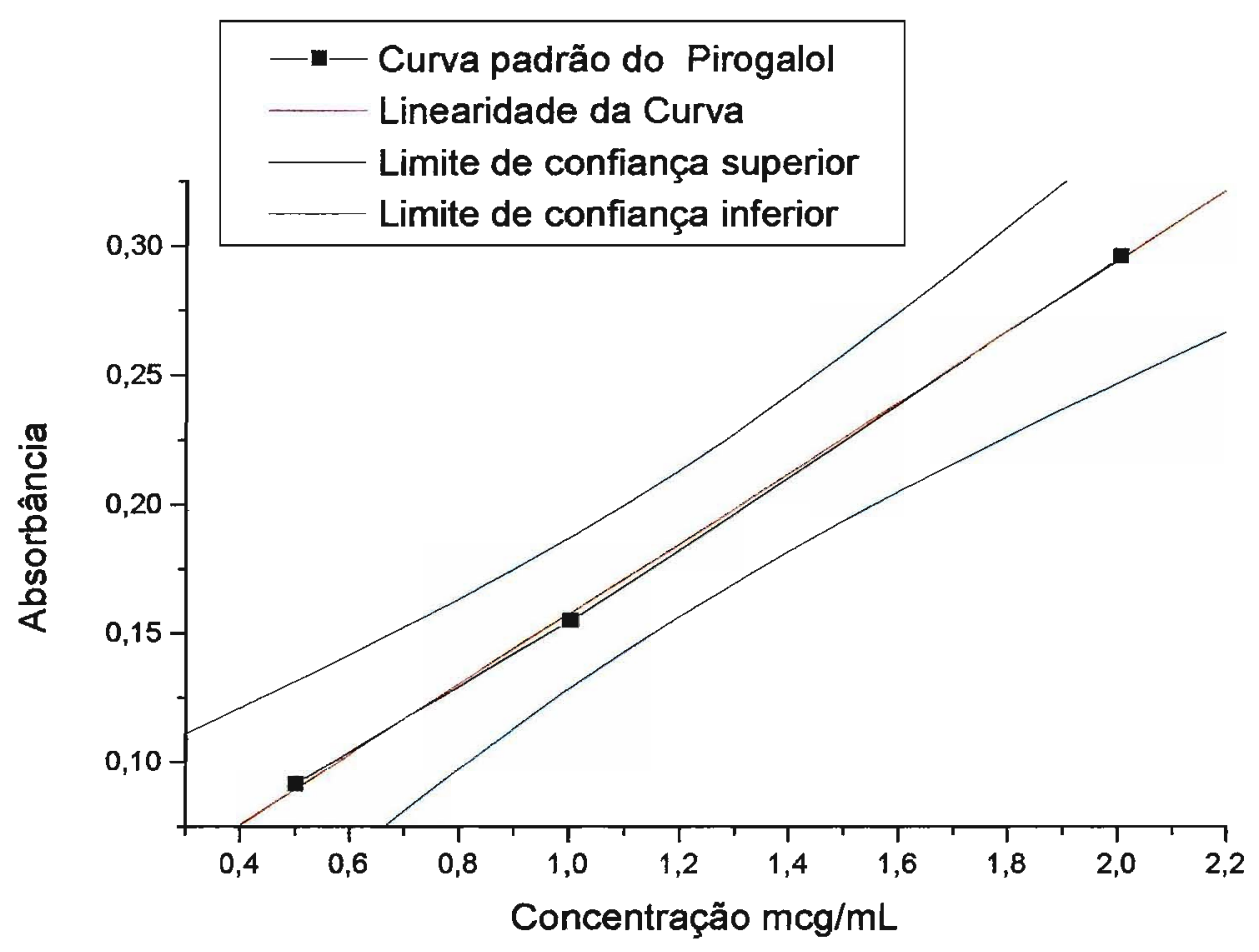

Cálculo do teor de taninos através da equação da reta

Linearidade $=0,99966$

Equação da reta: $y=A+B \times X$

$A=0,02096, b=0,13642$

Teor de taninos na droga $=2,86 \pm 0,01 \%$

Teor de taninos no EHA $=8,49 \pm 0,03 \%$ 


\subsubsection{Teor de saponinas}

O teor de saponinas obtido, segundo metodologia descrita por NAMBA e cols (1974), na droga vegetal em pó de $C$. xanthocarpa foi de $6,3 \%(\mathrm{~m} / \mathrm{m})$, e no extrato EHA foi de $16 \%(\mathrm{~m} / \mathrm{m})$.

\subsubsection{Teor de óleo essencial}

O óleo essencial obtido das folhas frescas de $C$. xanthocarpa por hidrodestilação apresentou-se como líquido amarelo claro, sendo o teor de $0,11 \%$ $(\mathrm{v} / \mathrm{m})$ em relação às folhas frescas.

5.2.7. Análise do óleo essencial por cromatografia gasosa acoplada a espectrômetro de massas. Identificação e quantificação dos principais constituintes.

Os componentes químicos identificados e quantificados do óleo essencial obtido de folhas frescas de C. xanthocarpa, foram durante o período de frutificação, em ensaios realizados através de análise cromatográfica em fase gasosa acoplada a espectrômetro de massa, encontram-se descritos na tabela $N^{\circ} 9$ 
Tabela 9. Principais componentes químicos identificados e quantificados (\%) do óleo essencial obtido de folhas frescas de $C$. xanthocarpa através de análise cromatográfica em fase gasosa acoplada a espectrômetro de massas.

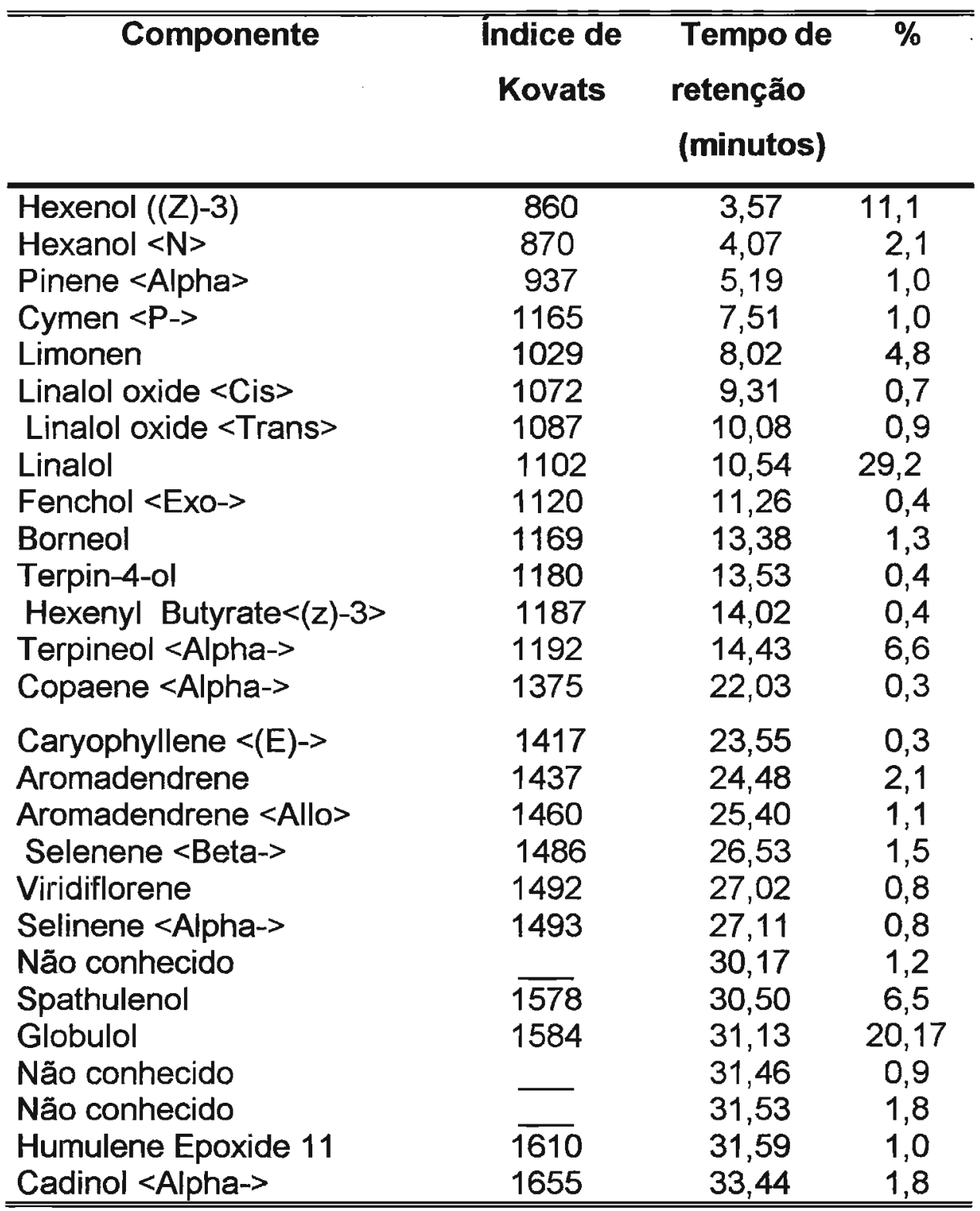




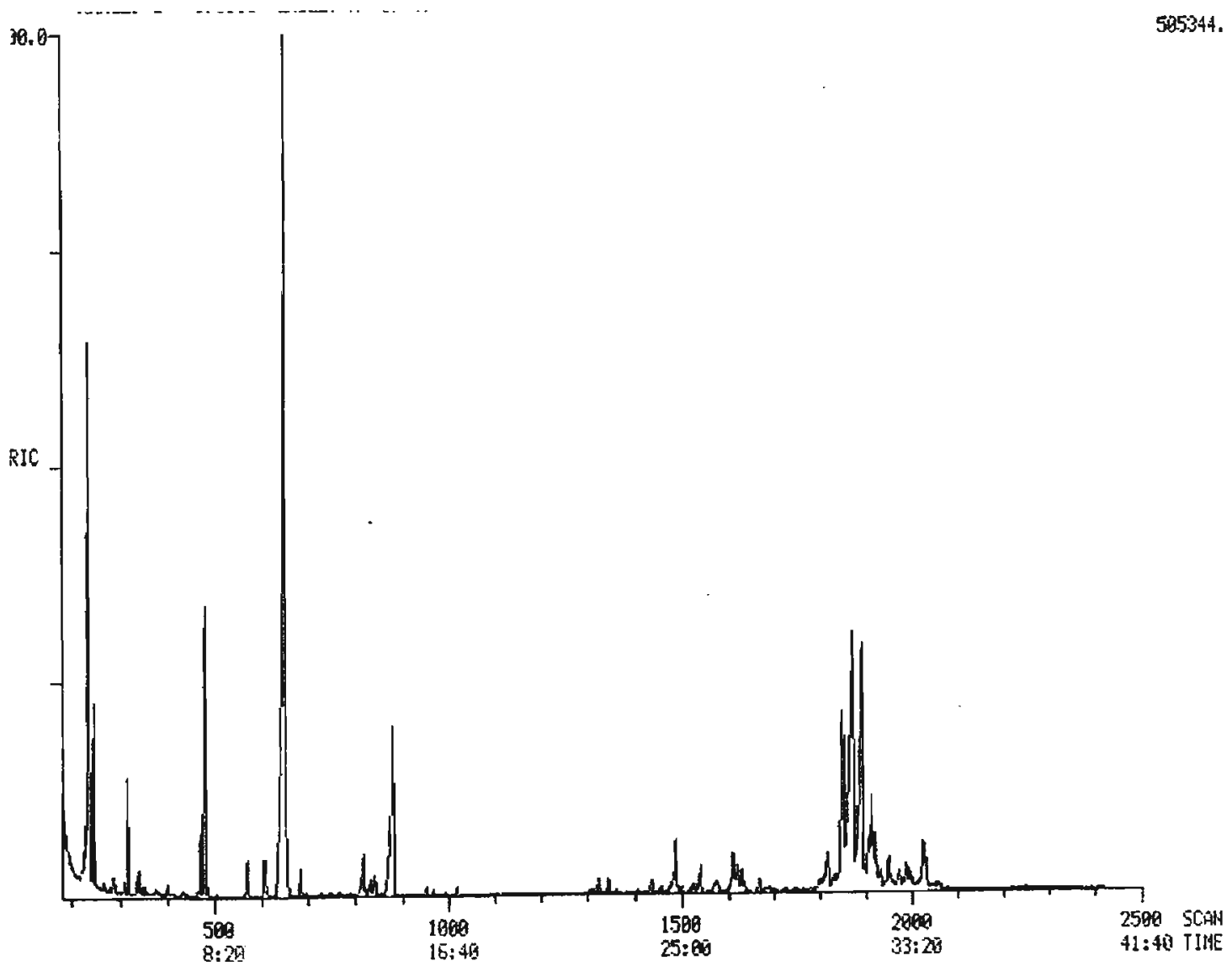

Fig. 31. Cromatograma obtido por cromatografia em fase gasosa do óleo essencial das folhas frescas de C. xanthocarpa durante o período de frutificação da planta. Condições de análise: cromatografia gasosa, temperatura do injetor $220^{\circ} \mathrm{C}$, temperatura inicial $60^{\circ} \mathrm{C}$, final $240^{\circ} \mathrm{C}$, rampa $3^{\circ} \mathrm{C} / \mathrm{min}$. 


\subsection{Ensaios biológicos}

\subsubsection{Toxicidade Aguda}

O ensaio realizado com o extrato EHA de C. xanthocarpa, na dose de $5 \mathrm{~g} / \mathrm{Kg}$ de peso do animal, não apresentou resultados expressivos de toxicidade aguda, conforme pode ser observado nos gráficos e tabelas apresentados. Não ocorreram óbitos no decorrer do ensaio porém, imediatamente após a administração oral do extrato, todos os camundongos mostraram-se prostrados. Nos 2 a 3 minutos iniciais, apresentaram tremores, e poucos reflexos a estímulos mecânicos. Após este periodo mostraram sonolência, agrupando-se em uma das extremidades da gaiola. As alterações foram menos intensas nas fêmeas. Decorridas três horas verificou-se comportamento semelhante dos animais tratados e controle.

Nos grupos controles não foram observadas alterações comportamentais.

As tabelas de $n^{\text {os }} 10$ a 15 e figuras de $n^{\text {os }} 32$ a 37 referem-se a observações de consumo de água, de ração, massa corpórea, massa relativa dos rins, dos fígados, dos corações e pulmões dos camundongos fêmeas controle e tratados. As tabelas de $n^{\text {os }} 16$ a 21 e figuras de $n^{\text {os }} 38$ a 43 representam as mesmas observações referentes aos camundongos machos controle e tratados. 
TABELA 10. Consumo de água dos camundongos fêmeas, controle e tratadas por via oral com o extrato EHA de C. xanthocarpa na dose de $5 \mathrm{~g} / \mathrm{Kg}$ de massa do animal, no ensaio de toxicidade aguda.

\begin{tabular}{ccc}
\hline \multirow{2}{*}{ Dias } & \multicolumn{2}{c}{ Consumo de água $(\mathrm{mL})$} \\
\cline { 2 - 3 } & Controle & Tratadas \\
\hline 1 & - & - \\
3 & 133 & 63 \\
5 & 72 & 75 \\
7 & 95 & 75 \\
9 & 150 & 65 \\
11 & 105 & 50 \\
\hline \multicolumn{3}{c}{$\mathrm{N}=5$}
\end{tabular}

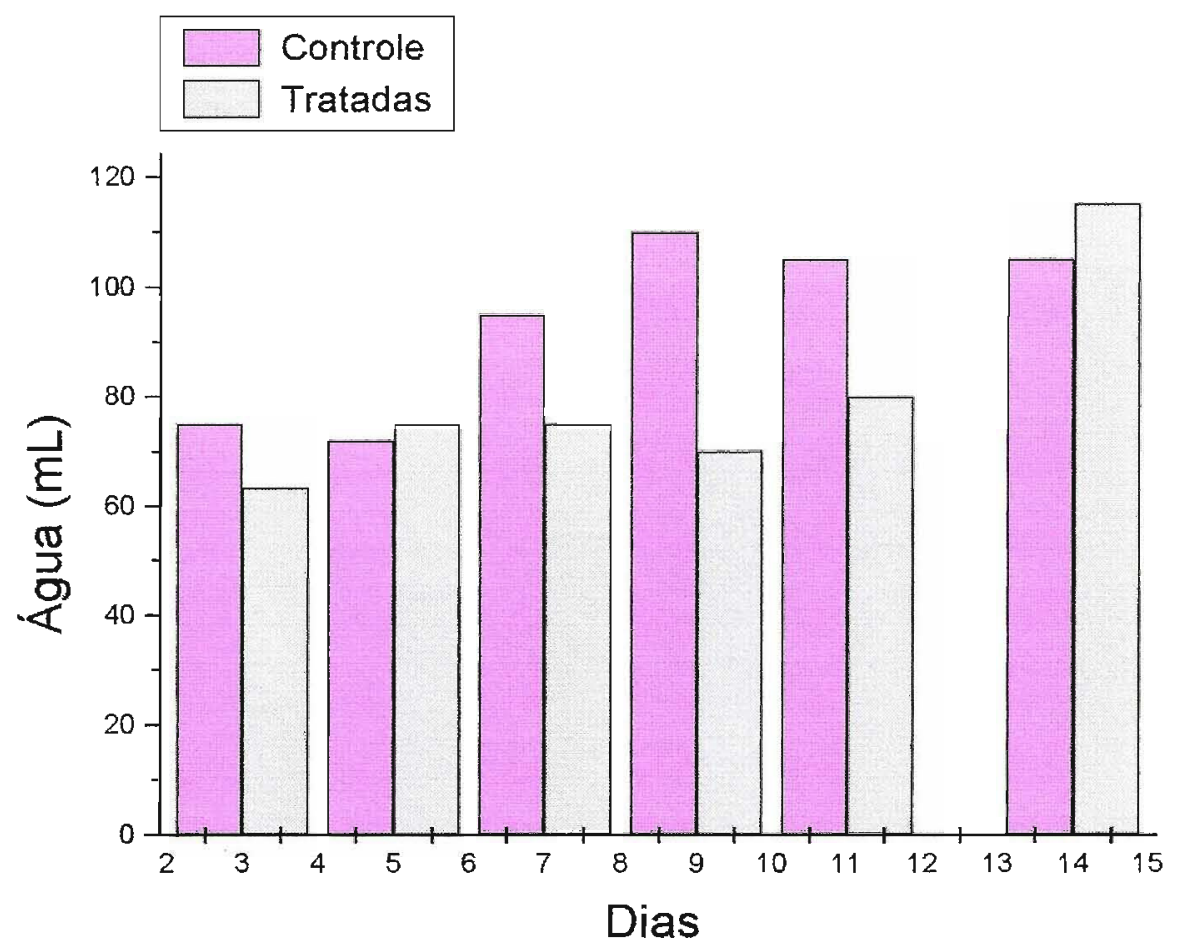

Figura 32. Consumo de água dos camundongos fêmeas, controle e tratadas por via oral com extrato EHA de C. xanthocarpa na dose de $5 \mathrm{~g} / \mathrm{kg}$ massa de animal no ensaio de toxicidade aguda. 
Tabela 11 Consumo de ração dos camundongos fêmeas, controle e tratadas por via oral com o extrato EHA de C. xanthocarpa, na dose de $5 \mathrm{~g} / \mathrm{Kg}$ de massa do animal, no ensaio de toxicidade aguda.

\begin{tabular}{ccc}
\hline \hline & \multicolumn{2}{c}{ Consumo de ração (g) } \\
\cline { 2 - 3 } Dias & Controle & Tratadas \\
\hline 1 & - & - \\
3 & 94,9 & 56,7 \\
5 & 104,4 & 90,4 \\
7 & 141,2 & 100,7 \\
9 & 178,8 & 140,0 \\
11 & 157,3 & 150,0 \\
14 & 142,3 & 187,1 \\
\hline \hline
\end{tabular}

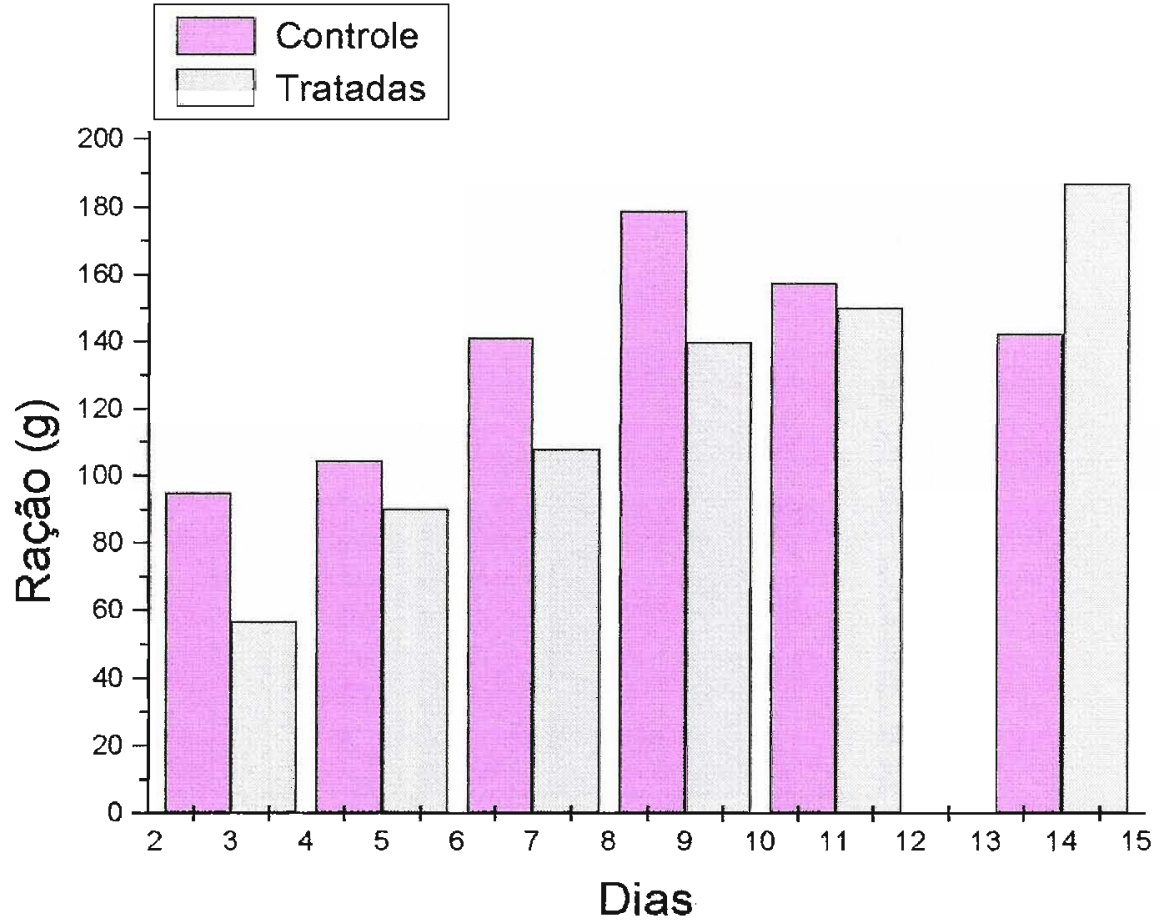

Figura 33. Consumo de ração dos camundongos fêmeas controle e tratadas por via oral com EHA de C. xanthocarpa na dose de $5 \mathrm{~g} / \mathrm{kg}$ massa de animal no ensaio de toxicidade aguda. 
Tabela 12. Massa média corpórea dos camundongos fêmeas, controle e tratadas por via oral com extrato EHA de C. xanthocarpa na dose $5 \mathrm{~g} / \mathrm{kg}$ de massa de animal, no ensaio de toxicidade aguda, $p>0,05$.

\begin{tabular}{ccc}
\hline & \multicolumn{2}{c}{ Massa corpórea $(\mathrm{g})$} \\
\cline { 2 - 3 } Dias & Controle & Tratadas \\
\hline 1 & $33,78 \pm 1,988$ & $31,08 \pm 1,2119$ \\
3 & $33,63 \pm 1,2656$ & $32,70 \pm 1,4131$ \\
5 & $34,12 \pm 1,0514$ & $32,33 \pm 1,7441$ \\
7 & $33,00 \pm 1,1739$ & $29,94 \pm 1,5384$ \\
9 & $32,48 \pm 1,7875$ & $35,78 \pm 1,4758$ \\
11 & $33,84 \pm 1,0317$ & $33,60 \pm 1,3416$ \\
14 & $33,43 \pm 2,1818$ & $34,90 \pm 1,7396$
\end{tabular}

Os resultados representam a média \pm epm, de massa corpórea. $\mathrm{N}=5$

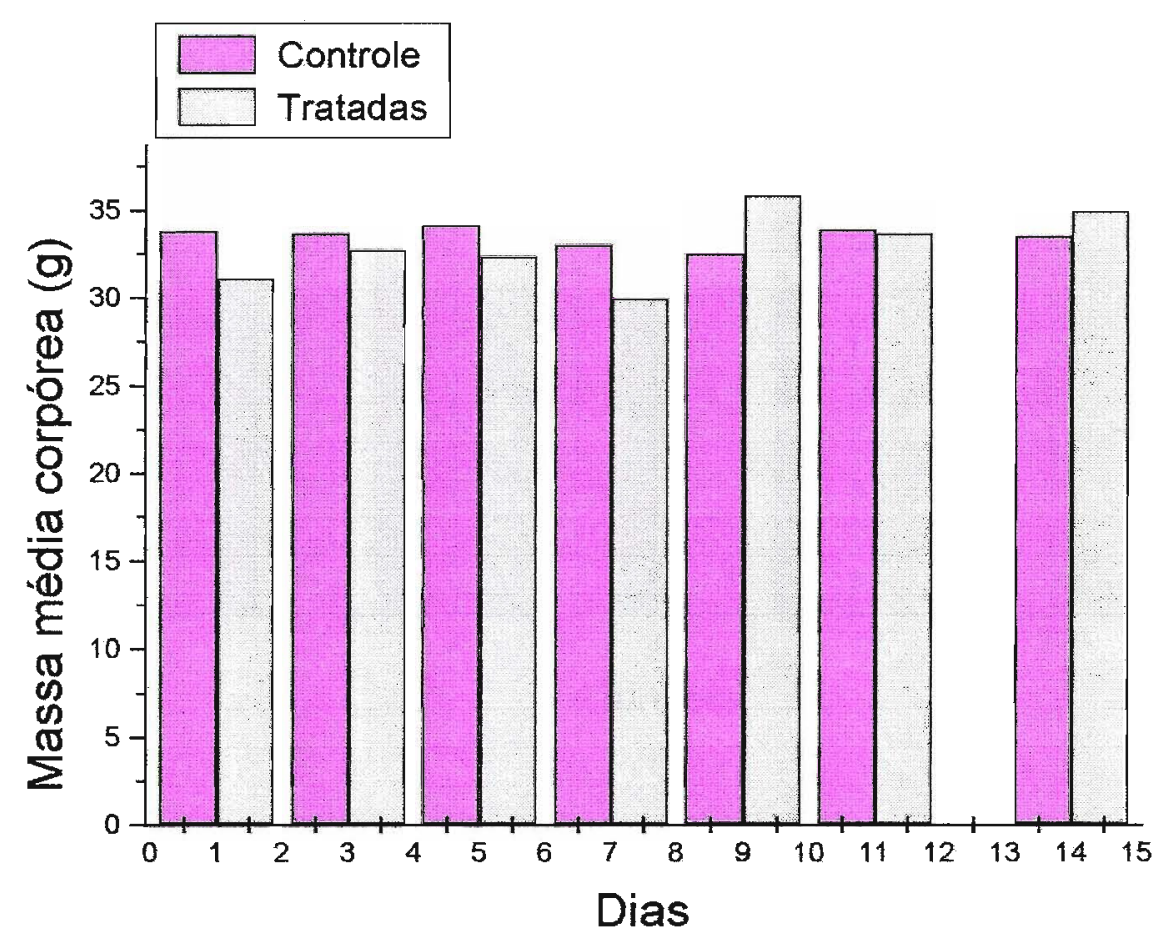

Figura 34. Massa média corpórea dos camundongos fêmeas, controle e tratadas por via oral com EHA de $C$. xanthocarpa na dose de $5 \mathrm{~g} / \mathrm{kg}$ de massa de animal, no ensaio de toxicidade aguda. 
Tabela 13. Massa relativa dos rins dos camundongos fêmeas controle e tratadas por via oral com extrato EHA de C. xanthocarpa na dose de $5 \mathrm{~g} / \mathrm{kg}$ de massa de animal, no ensaio de toxicidade aguda, $p>0,05$.

\begin{tabular}{ccc}
\hline \hline \multirow{2}{*}{ Animal } & \multicolumn{2}{c}{ Massa relativa dos rins dos camundongos fêmeas $\times 10^{-2}$} \\
\cline { 2 - 3 } & Controle & Tratadas \\
\hline 1 & 1,208 & 1,376 \\
3 & 1,447 & 1,187 \\
4 & 1,984 & 1,112 \\
5 & 1,347 & 1,307 \\
\hline \hline
\end{tabular}

Massa relativa $=$ massa dos rins/massa corpórea do animal. $\mathrm{N}=5$

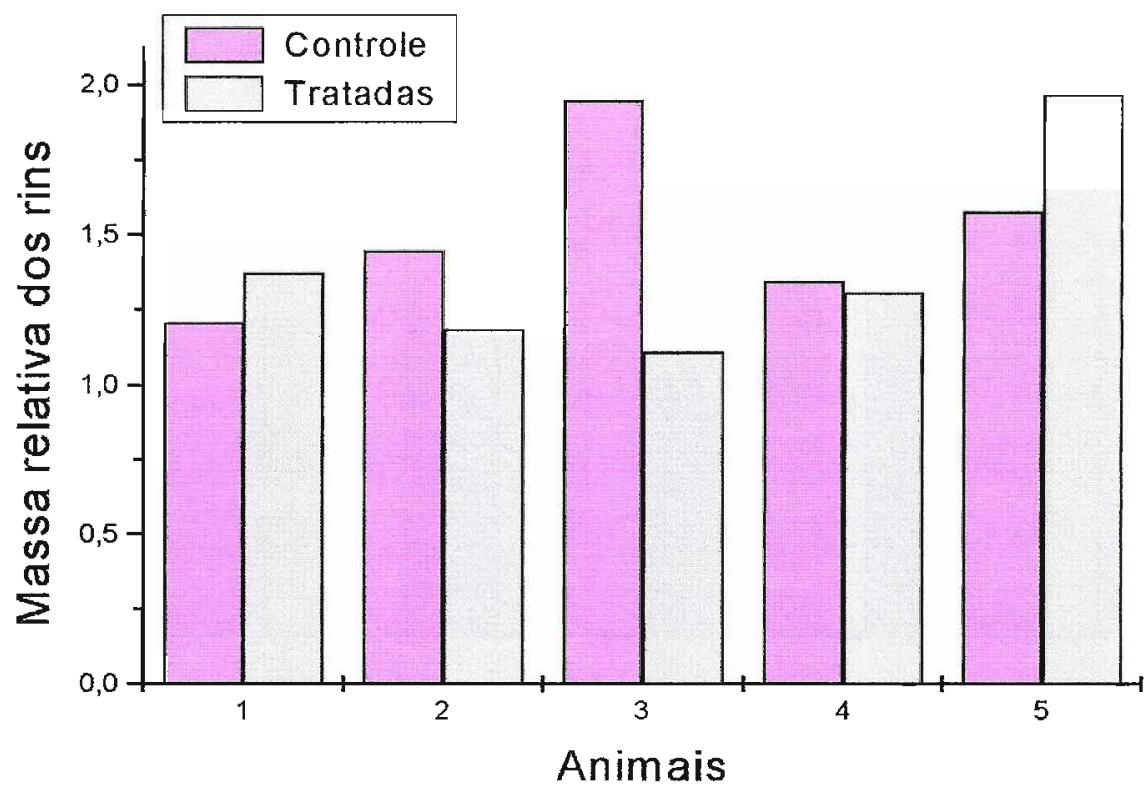

Figura 35. Massa relativa dos rins dos camundongos fêmeas, controle $e$ tratadas por via oral com EHA de C. xanthocarpa na dose de $5 \mathrm{~g} / \mathrm{kg}$ de massa de animal, no ensaio de toxicidade aguda. 
Tabela 14. Massa relativa dos fígados dos camundongos fêmeas controle e tratadas por via oral com o extrato EHA de C. xanthocarpa, na dose de $5 \mathrm{~g} / \mathrm{Kg}$ de massa de animal, no ensaio de toxicidade aguda, $p>0,05$.

\begin{tabular}{ccc}
\hline \hline & \multicolumn{2}{c}{ Massa relativa dos fígados dos camundongos fêmeas $\times 10^{-2}$} \\
\cline { 2 - 3 } Animal & Controle & Tratadas \\
\hline 1 & 5,877 & 5,079 \\
2 & 5,818 & 6,186 \\
3 & 8,135 & 6,717 \\
4 & 5,693 & 5,619 \\
5 & 5,091 & 5,498 \\
\hline
\end{tabular}

Massa relativa $=$ massa do fígado/massa corpórea do animal. $\mathrm{N}=5$

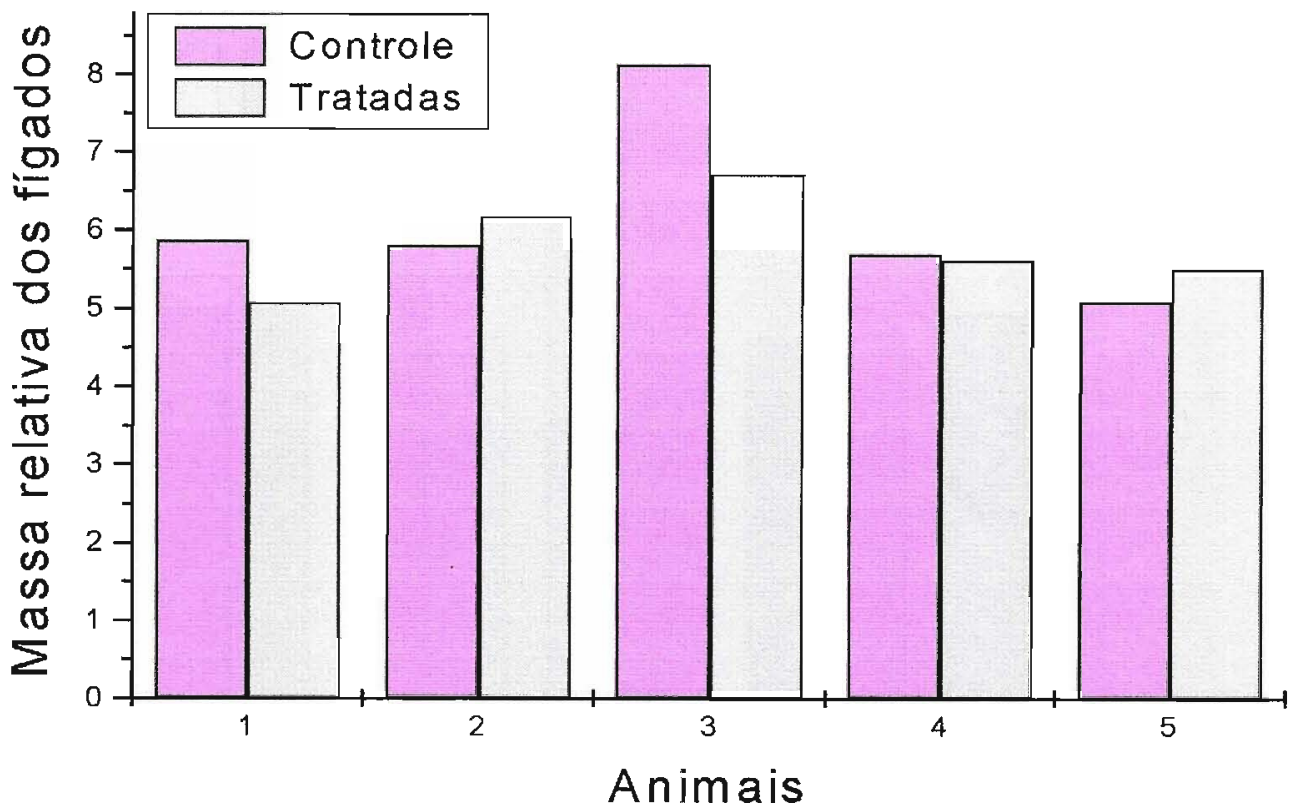

Figura 36. Massa relativa de fígados dos camundongos fêmeas controle e tratadas por via oral com $5 \mathrm{~g} / \mathrm{Kg}$ do extrato EHA de C. xanthocarpa na dose de $5 \mathrm{~g} / \mathrm{kg}$ de massa de animal, no ensaio de toxicidade aguda. 
Tabela 15. Massa relativa de coração e pulmões dos camundongos fêmeas, controle e tratadas por via oral com extrato EHA de C. xanthocarpa na dose de $5 \mathrm{~g} / \mathrm{kg}$ de massa de animal, no ensaio de toxicidade aguda, $p>005$.

\begin{tabular}{ccc}
\hline & \multicolumn{2}{c}{ Massa relativa de coração e pulmões dos camundongos fêmeas $\times 10^{-2}$} \\
\cline { 2 - 3 } Animal & Controle & Tratadas \\
\hline 1 & 1,483 & 1,560 \\
2 & 1,597 & 1,385 \\
3 & 2,183 & 1,411 \\
4 & 1,373 & 1,391 \\
5 & 1,444 & 1,532 \\
\hline \hline
\end{tabular}

Massa relativa $=$ massa de coração e pulmões/massa corpórea do animal. $\mathrm{N}=5$

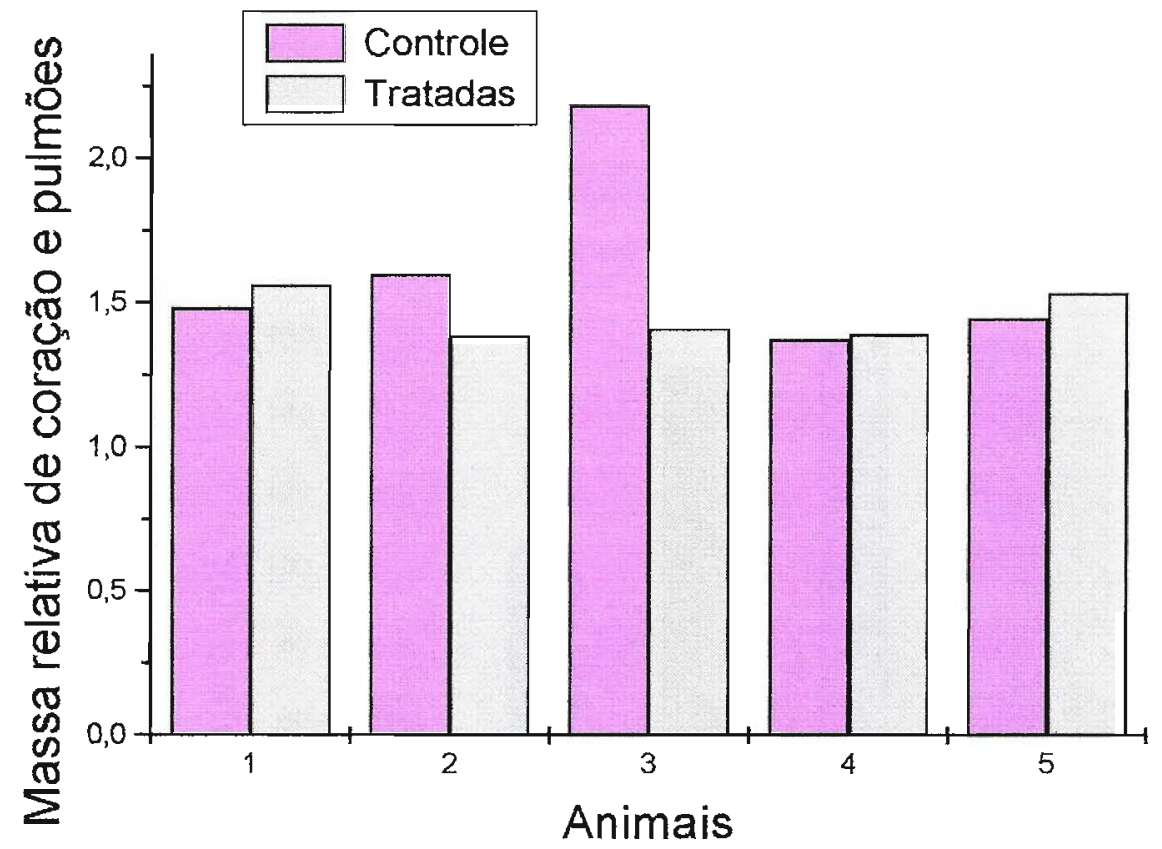

Figura 37. Massa relativa de coração e pulmões dos camundongos fêmeas, controle e tratadas por via oral com o extrato EHA de C. xanthocarpa na dose de $5 \mathrm{~g} / \mathrm{kg}$ de massa de animal, no ensaio de toxicidade aguda. 
Tabela 16. Consumo de água dos camundongos machos controle e tratados por via oral com o extrato EHA de C. xanthocarpa na dose de $5 \mathrm{~g} / \mathrm{Kg}$ de massa de animal, no ensaio de toxicidade aguda.

\begin{tabular}{ccc}
\hline \hline & \multicolumn{2}{c}{ Consumo de água $(\mathrm{mL})$} \\
\cline { 2 - 3 } Dias & Controle & Tratados \\
\hline 1 & - & - \\
3 & 66,7 & 40,0 \\
5 & 105,0 & 90,0 \\
7 & 153,0 & 88,0 \\
9 & 162,0 & 93,8 \\
11 & 160,0 & 140,0 \\
14 & 142,0 & 118,0 \\
\hline \hline
\end{tabular}

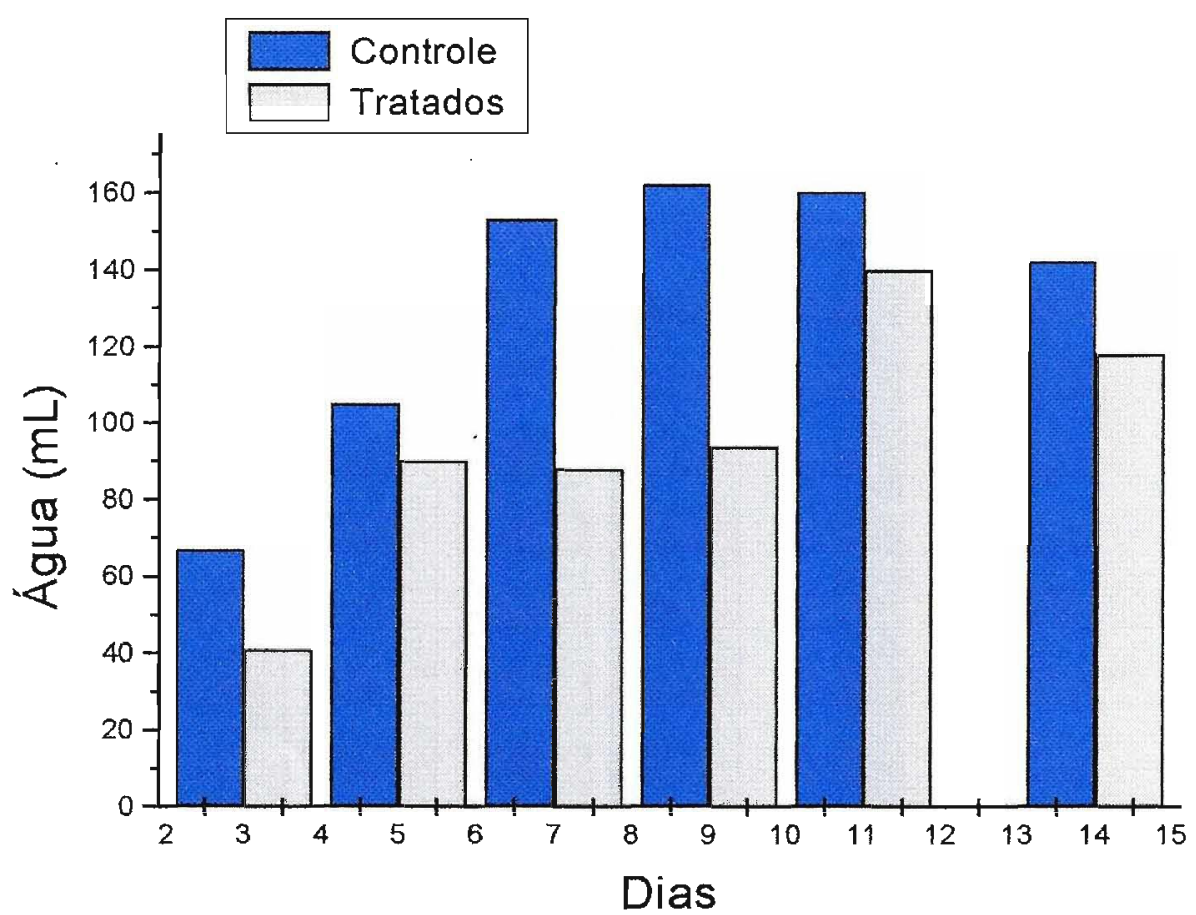

Figura 38. Consumo de água, dos camundongos machos, controle e tratados por via oral com EHA de C. xanthocarpa na dose de $5 \mathrm{~g} / \mathrm{kg}$ massa de animal, no ensaio de toxicidade aguda. 
Tabela 17. Consumo de ração, dos camundongos machos, controle e tratados por via oral com o extrato EHA de C. xanthocarpa na dose de $5 \mathrm{~g} / \mathrm{Kg}$ de massa de animal, no ensaio de toxicidade aguda.

\begin{tabular}{ccc}
\hline & \multicolumn{2}{c}{ Consumo de ração(g) } \\
\cline { 2 - 3 } Dias & Controle & Tratados \\
\hline 1 & - & - \\
3 & 63 & 60 \\
5 & 103 & 118,14 \\
7 & 120 & 124 \\
9 & 127 & 128,4 \\
11 & 170 & 178,71 \\
14 & 188 & 200,30 \\
\hline \multicolumn{3}{c}{$\mathrm{N}=5$} \\
\hline
\end{tabular}

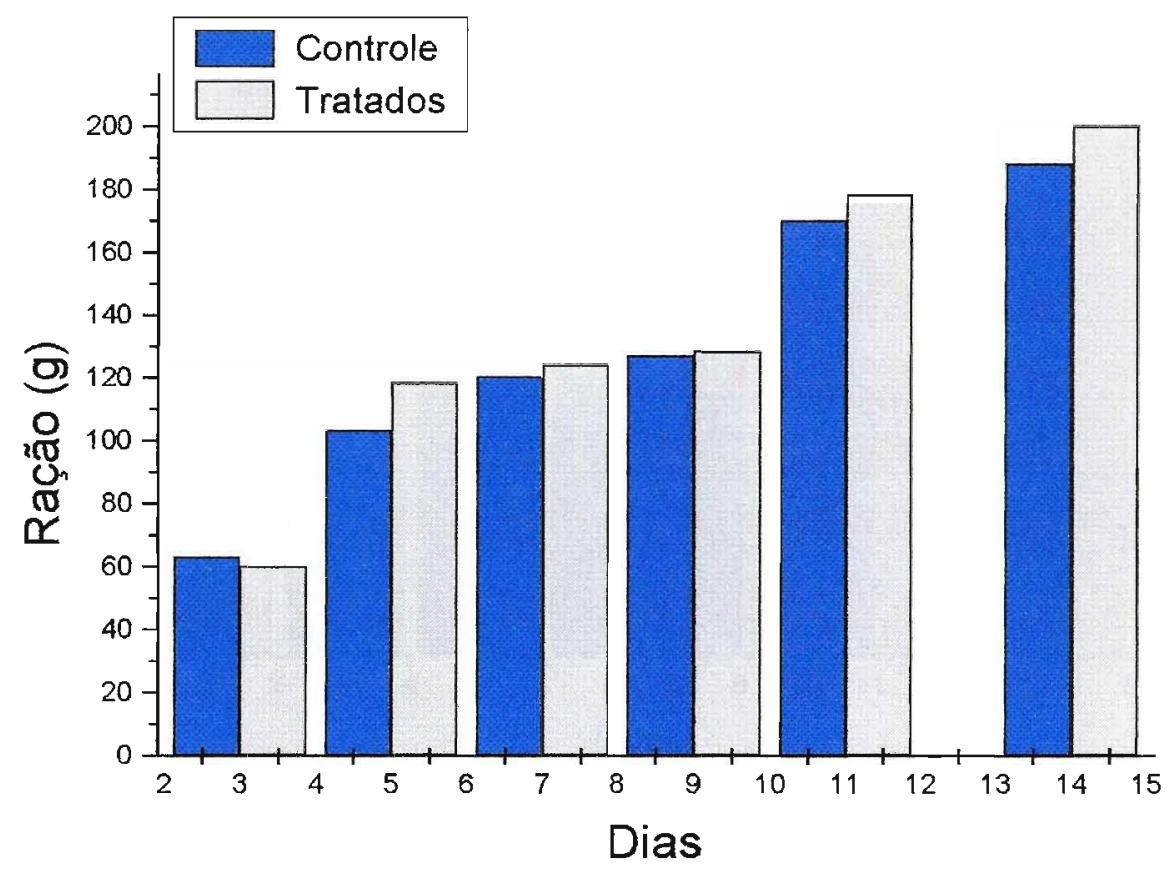

Figura 39. Consumo de ração, dos camundongos machos, controle e tratados por via oral com extrato EHA de C. xanthocarpa na dose de $5 \mathrm{~g} / \mathrm{Kg}$ de massa de animal, no ensaio de toxicidade aguda. 
Tabela 18. Massa corpórea média, dos camundongos machos, controle e tratados por via oral com o extrato EHA de C. xanthocarpa na dose de $5 \mathrm{~g} / \mathrm{Kg}$ de massa de animal, durante o ensaio de toxicidade aguda, $p>0,05$.

\begin{tabular}{ccc}
\hline \multirow{2}{*}{ Dias } & \multicolumn{2}{c}{ Massa corpórea média } \\
\cline { 2 - 3 } & Controle & Tratados \\
\hline 1 & $32,95 \pm 1,221$ & $35,39 \pm 0,912$ \\
3 & $35,23 \pm 1,681$ & $34,45 \pm 1,905$ \\
5 & $34,29 \pm 1,695$ & $35,69 \pm 2,347$ \\
7 & $36,10 \pm 1,824$ & $36,76 \pm 2,263$ \\
9 & $37,34 \pm 1,252$ & $37,44 \pm 1,646$ \\
11 & $36,34 \pm 1,408$ & $38,58 \pm 1,493$ \\
14 & $36,15 \pm 2,499$ & $39,40 \pm 0,984$
\end{tabular}

Os resultados representam a massa média \pm erro padrão. $\mathrm{N}=5$

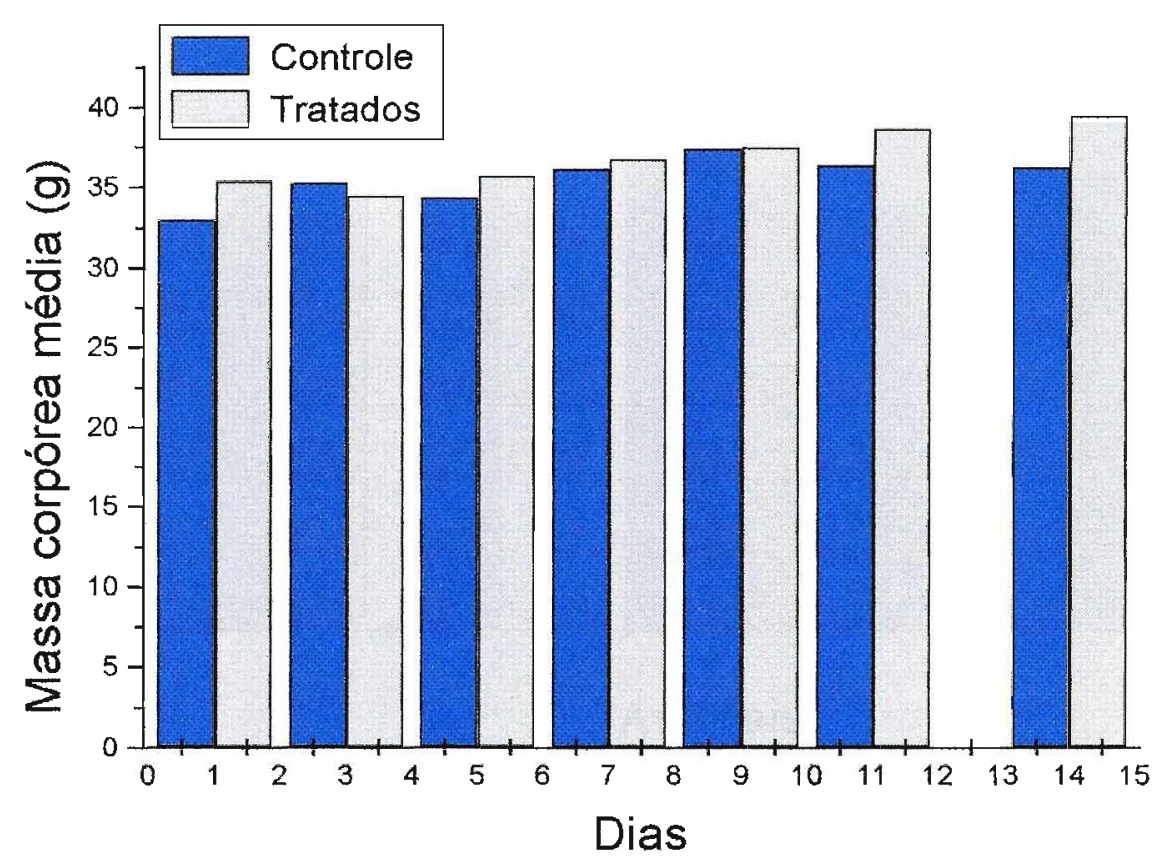

Figura 40. Massa corpórea média os camundongos machos, controle e tratados por via oral com o extrato EHA de C. xanthocarpa na dose de $5 \mathrm{~g} / \mathrm{kg}$ de massa de animal, no ensaio de toxicidade aguda. 
Tabela19. Massa relativa dos rins dos camundongos machos, controle e tratados por via oral com o extrato EHA de C. xanthocarpa na dose de $5 \mathrm{~g} / \mathrm{Kg}$ de massa de animal, no ensaio de toxicidade aguda, $p>0,05$.

\begin{tabular}{ccc}
\hline & \multicolumn{2}{c}{ Massa relativa dos rins de camundongos machos $\times 10^{-2}$} \\
\cline { 2 - 3 } Animal & Controle & Tratados \\
\hline 1 & 1,692 & 1,905 \\
2 & 1,734 & 2,041 \\
3 & 1,642 & 1,970 \\
4 & 2,083 & 1,763 \\
5 & 1,831 & 1,576
\end{tabular}

Massa relativa $=$ massa dos rins/massa corpórea do animal. $\mathrm{N}=5$

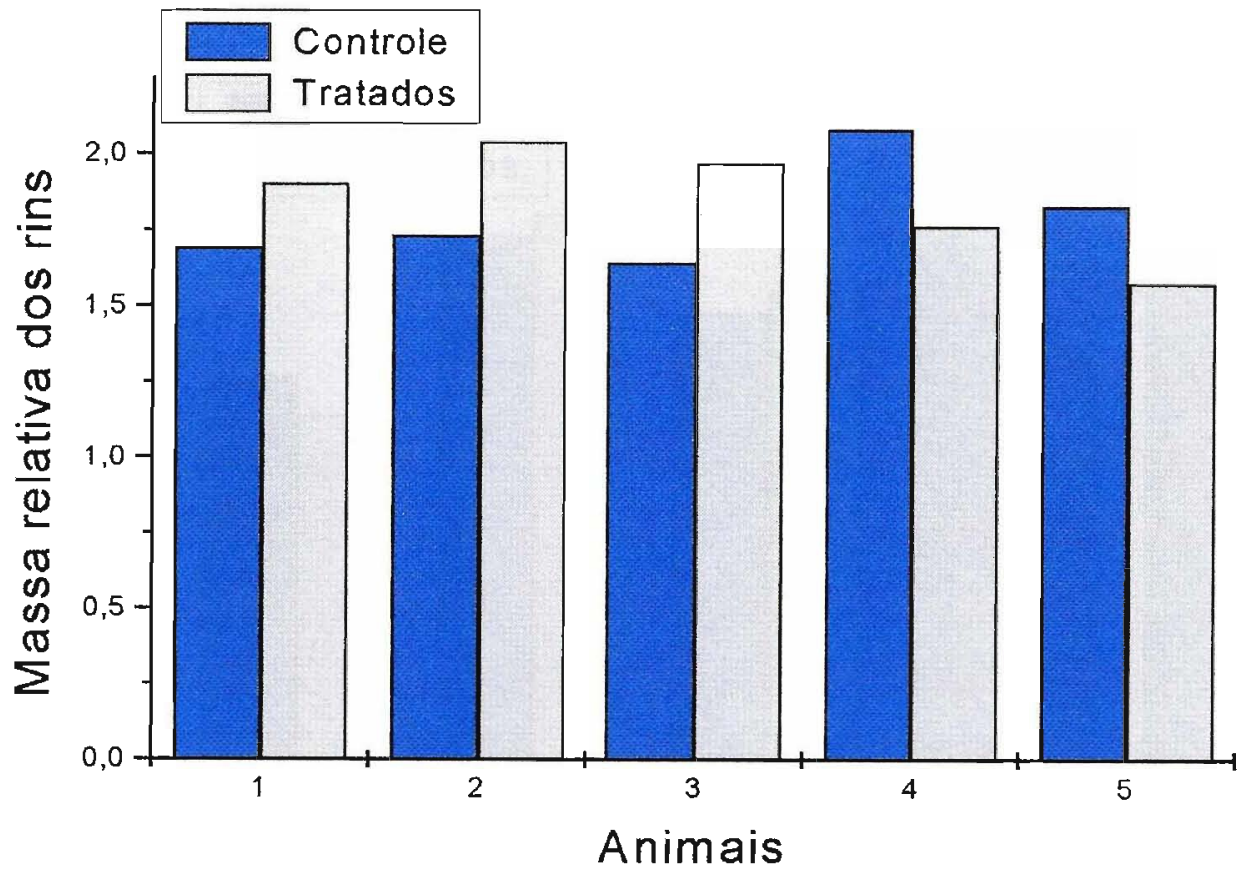

Figura 41. Massa relativa dos rins dos camundongos machos, controle e tratados por via oral com o extrato EHA de C. xanthocarpa na dose de $5 \mathrm{~g} / \mathrm{kg}$ de massa de animal, no ensaio de toxicidade aguda. 
Tabela 20. Massa relativa de fígados dos camundongos machos, controle e tratados por via oral com o extrato de EHA de C. xanthocarpa na dose de $5 \mathrm{~g} / \mathrm{Kg}$ de massa de animal, no ensaio de toxicidade aguda, $p>0,05$.

\begin{tabular}{ccc}
\hline \hline \multirow{2}{*}{ Animal } & \multicolumn{2}{c}{ Massa relativa de fígados dos camundongos machos $\times 10^{-2}$} \\
\cline { 2 - 3 } & Controle & Tratados \\
\hline 1 & 5,658 & 5,177 \\
3 & 7,402 & 7,642 \\
4 & 6,423 & 6,683 \\
5 & 7,687 & 7,025 \\
\hline \hline
\end{tabular}

Massa relativa $=$ massa do fígado/massa corpórea do animal. $\mathrm{N}=5$

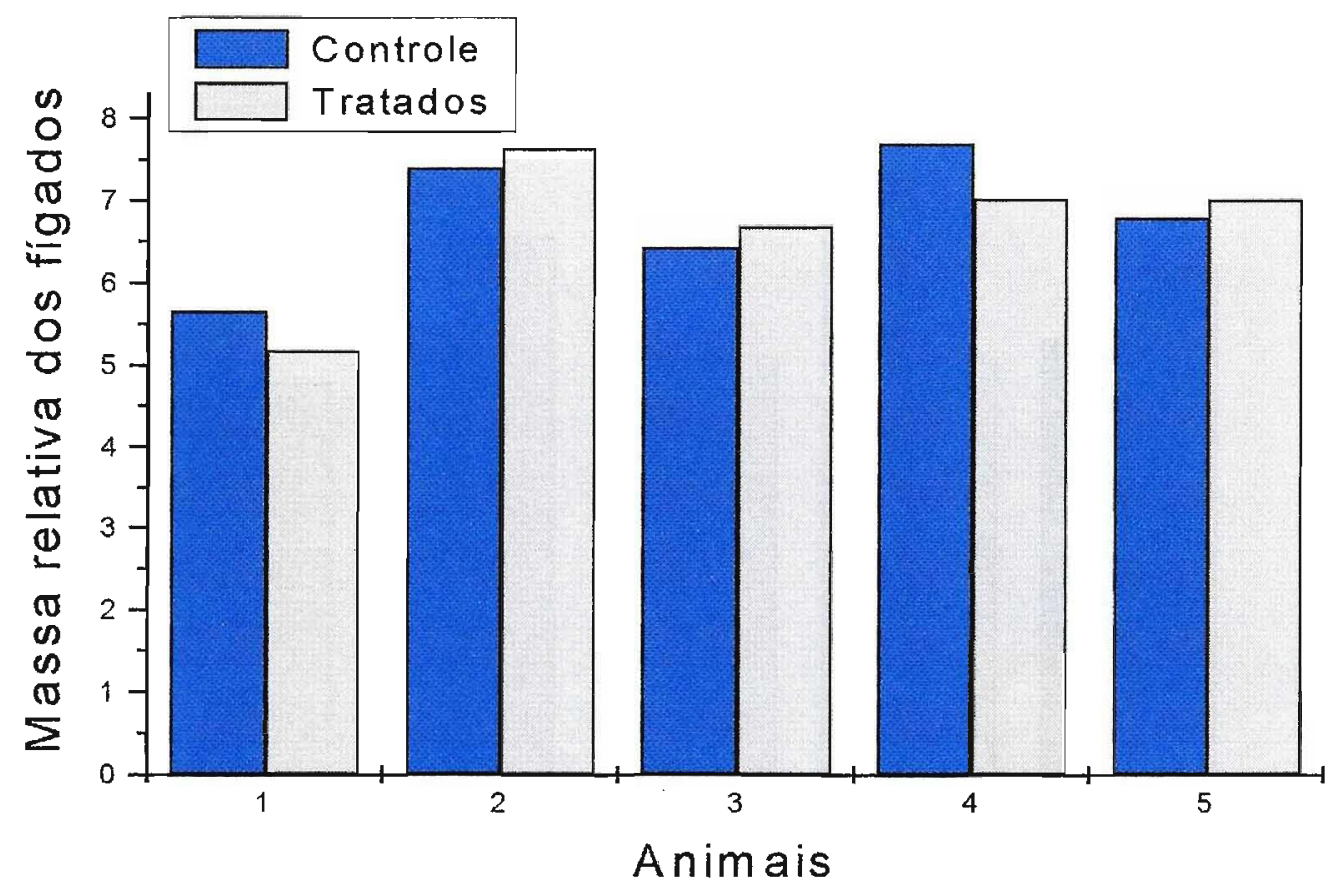

Figura 42. Massa relativa de fígados dos camundongos machos, controle e tratados por via oral como extrato EHA de C. xanthocarpa na dose de $5 \mathrm{~g} / \mathrm{kg}$ de massa de animal, no ensaio de toxicidade aguda. 
Tabela 21. Massa relativa dos corações e pulmões dos camundongos machos, controle e tratados por via oral com o extrato de EHA de C. xanthocarpa na dose de $5 \mathrm{~g} / \mathrm{Kg}$ de massa de animal, no ensaio de toxicidade aguda, $p>0,05$.

\begin{tabular}{ccc}
\hline \hline & \multicolumn{2}{c}{ Massa relativa de coração e pulmões dos camundongos machos $\times 10^{-2}$} \\
\cline { 2 - 3 } Animal & Controle & Tratados \\
\hline 1 & 1,322 & 1,148 \\
2 & 1,272 & 1,543 \\
3 & 1,267 & 1,222 \\
4 & 1,724 & 1,216 \\
5 & 1,265 & 1,464
\end{tabular}

Massa relativa = massa de coração e pulmões/massa corpórea do animal. $\mathrm{N}=5$

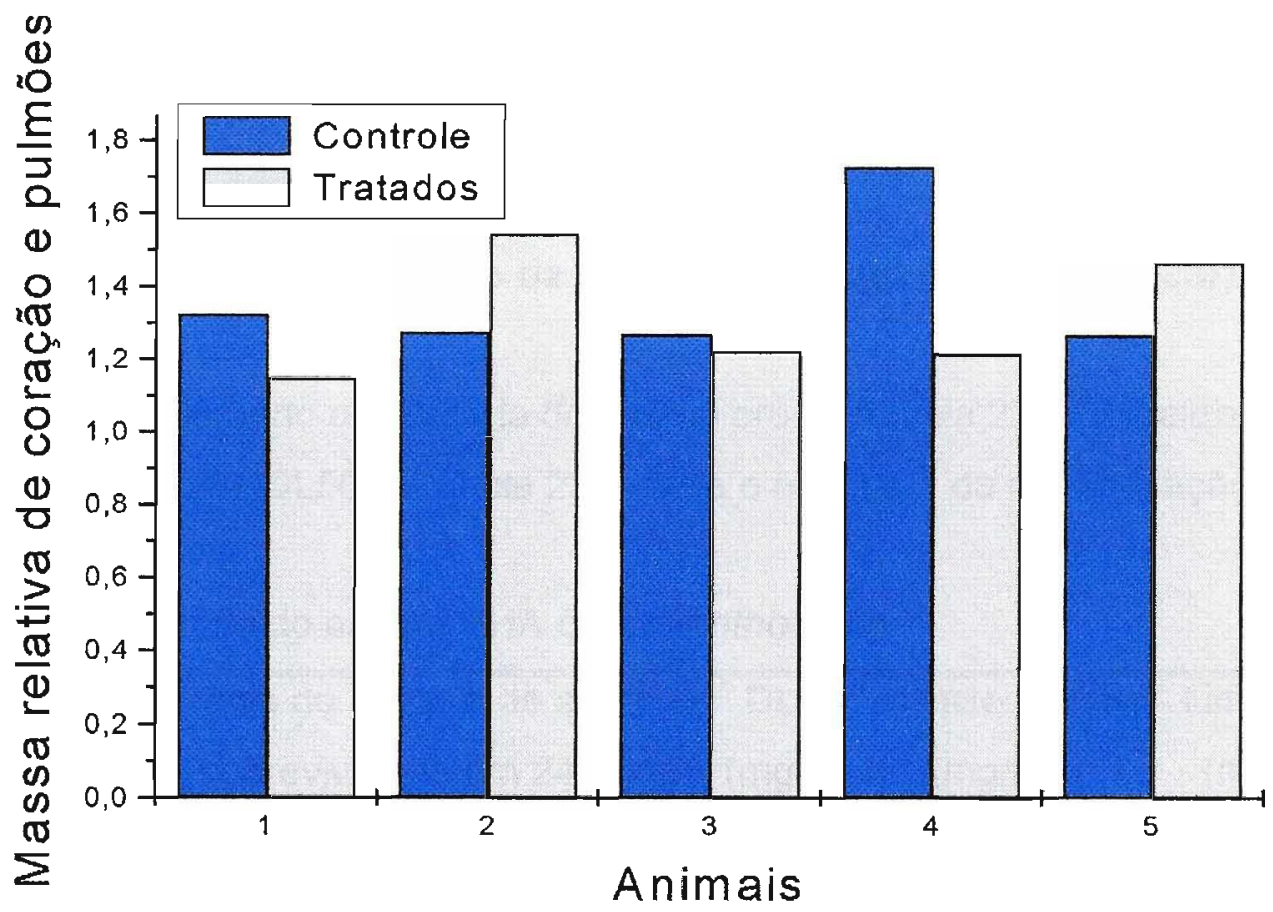

Figura 43. Massa relativa de coração e pulmões dos camundongos machos, controle e tratados por via oral com EHA de C. xanthocarpa na dose de $5 \mathrm{~g} / \mathrm{kg}$ de massa de animal, no ensaio de toxicidade aguda. 


\subsubsection{Ensaio da letalidade da artêmia}

\subsubsection{Triagem}

A triagem foi realizada com o extrato EHA de C. xanthocarpa, com dose única, resultando em letalidade acima de $50 \%$. A tabela 22 apresenta o resultado da avaliação prévia da letalidade das artêmias

Tabela 22. Avaliação prévia da letalidade das artêmias com o extrato EHA de C. xanthocarpa

\begin{tabular}{lcc}
\hline \hline & $\begin{array}{c}\text { Número de artêmias sobreviventes } \\
\text { em } 24 \text { horas }\end{array}$ & em 48 horas \\
\hline Dose única (EHA) $1 \mathrm{mg} / \mathrm{mL}$ & 4 & 1 \\
Controle & 10 & 10 \\
& & \\
\hline \hline & $\mathrm{N}=10$
\end{tabular}

\subsubsection{Determinação da DL 50 do extrato de C. xanthocarpa em} artêmias.

Considerando o resultado do ensaio prévio (tabela 22) foi realizada a determinação da DL50. A tabela 23 mostra o resultado da determinação da DL 50

Tabela 23. DL 50 do extrato EHA de C. xanthocarpa.

\begin{tabular}{lcccc}
\hline \hline Dose & $\begin{array}{c}\text { Média do número de artêmias } \\
\text { sobreviventes em 24 horas }\end{array}$ & $\begin{array}{c}\text { DL50 } \\
(\mathrm{mg} / \mathrm{mL})\end{array}$ & $\begin{array}{c}\text { Limite superior } \\
(\mathrm{mg} / \mathrm{mL})\end{array}$ & $\begin{array}{c}\text { Limite inferior } \\
(\mathrm{mg} / \mathrm{mL})\end{array}$ \\
\hline $0,5 \mathrm{mg} / \mathrm{mL}$ & 4 & 0,503 & 3,643 & 0,199 \\
$0,1 \mathrm{mg} / \mathrm{mL}$ & 9 & - & - & - \\
$0,02 \mathrm{mg} / \mathrm{mL}$ & 9 & - & - & - \\
\hline \hline
\end{tabular}

Média do número de artêmias sobreviventes, de três valores. $G=0,466$. Qui quadrado para 2 graus de liberdade : 1,551 .

É considerado resultado significativo para valores de DL50 $\leq 1000 \mu \mathrm{g} / \mathrm{mL}$, sendo indicativos para ensaios de citotoxicidade.

$\mathrm{G}=0,466$; Qui quadrado para 2 graus de liberdade: 1,551 


\subsubsection{Atividade antimicrobiana}

O resultado da avaliação da atividade antimicrobiana do extrato EHA é apresentado na tabela 24. O EHA de C. xanthocarpa evdenciou indicação de atividade biostática para Staphylococcus aureus, Salmonella cholerasuis e Candida albicans. Observou-se crescimento nas sub-culturas realizadas nos tubos que mostraram inibição, porém apresentaram precipitado.

Tabela 24. Avaliação da atividade antimicrobiana do extrato EHA de Campomanesia xanthocarpa.

\begin{tabular}{|c|c|c|c|c|c|c|c|c|}
\hline & \multirow{2}{*}{$\begin{array}{l}\text { Controle } \\
\text { Positivo }\end{array}$} & \multirow{2}{*}{$\begin{array}{l}\text { Controle } \\
\text { Negativo }\end{array}$} & \multirow[t]{2}{*}{ Diluente } & \multicolumn{5}{|c|}{ Amostra (concentração $=\mathrm{mg} / \mathrm{mL}$ ) } \\
\hline & & & & 2,0 & 1,5 & 1,0 & 0,5 & 0,1 \\
\hline $\begin{array}{l}\text { Staphylococcus } \\
\text { aureus }\end{array}$ & +++ & -- & +++ & --- & -- & -- & +++ & +++ \\
\hline $\begin{array}{l}\text { Salmonella } \\
\text { cholerasuis }\end{array}$ & +++ & -- & +++ & --- & $\cdots$ & $\cdots$ & -- & +++ \\
\hline $\begin{array}{l}\text { Pseudomonas } \\
\text { aeruginosa }\end{array}$ & +++ & $-\cdots$ & +++ & +++ & +++ & +++ & +++ & +++ \\
\hline $\begin{array}{l}\text { Escherichia } \\
\text { coli }\end{array}$ & +++ & -- & +++ & +++ & +++ & +++ & +++ & +++ \\
\hline $\begin{array}{l}\text { Candida } \\
\text { albicans }\end{array}$ & +++ & -- & +++ & --- & -- & -- & +++ & +++ \\
\hline $\begin{array}{l}\text { Aspergillus } \\
\text { niger }\end{array}$ & +++ & -- & +++ & +++ & +++ & +++ & +++ & +++ \\
\hline
\end{tabular}

Os testes de esterilidade da amostra com o diluente, da amostra com o meio de ágar Sabourad - dextrose, e ágar-caseina soja , e dos meios de cultura não apresentaram contaminação microbiana. 
A tabela 25 mostra os valores encontrados para a concentração mínima inibitória do extrato EHA de C. xanthocarpa em relação a Staphylococcus aureus, Salmonella choleraesuis e Candida albicans.

Tabela 25. Determinação da Concentração mínima inibitória de ampicilina sódica, nistatina e do extrato EHA de C. xanthocarpa.

\begin{tabular}{llc}
\hline \hline Microrganismo & $\begin{array}{l}\text { Antibiótico } \\
\text { Amostra }\end{array}$ & $\begin{array}{c}\text { Concentração mínima inibitória } \\
\mu \mathrm{g} / \mathrm{mL}\end{array}$ \\
\hline Staphylococcus aureus & $\begin{array}{l}\text { Ampicilina sódica } \\
\text { Extrato EHA }\end{array}$ & $<1000 \mathrm{e}>500$ \\
& Ampicilina sódica & 100 \\
Salmonella choleraesuis & Extrato EHA & $<500$ e $>100$ \\
& Nistatina & 770 \\
Candida albicans & Extrato EHA & $<1000$ e $>500$ \\
\hline \hline
\end{tabular}




\subsubsection{Atividade antiúlcera}

5.3.4.1. Modelo de indução aguda por ácido clorídrico a $0,3 \mathrm{M} \mathrm{em}$ etanol a $60 \%$

Os resultados da administração oral do extrato EHA de C. xanthocarpa na incidência de lesões gástricas agudas induzidas por ácido clorídrico 0,3 $\mathrm{M}$ em etanol $60 \%$, são apresentados nas tabelas de $n^{\circ 5} 25$ a 27 e figuras de $n^{\text {os }} 45$ a 47 . O ensaio de atividade antiúlcera, no nível $\mid$ de ulceração apresentou o valor de $p<0,05$ significativo em relação ao grupo controle. Nos níveis II e III, o valor de $p<0,001$ para o extrato EHA de C. xanthocarpa, e misoprostol foi extremamente significativo em relação ao controle, na dose $400 \mathrm{mg} / \mathrm{kg}$, por via oral. O percentual de proteção foi de $62 \%$ para o grupo tratado com EHA de Campomanesia xanthocarpa, e $64 \%$ para o grupo tratado com a droga padrão misoprostol.

Os estômagos dos animais tratados com extrato EHA de Campomanesia xanthocarpa apresentaram precipitado, preservação das vilosidades, e a coloração mais clara, quando comparados com dos animais tratados com a droga padrão misoprostol (figura 44). 
Tabela 26. Média do número de ulcerações do nível I, induzidas por ácido clorídrico 0,3M em etanol, nos grupos de animais tratados por via oral com 400 $\mathrm{mg} / \mathrm{kg}$ do extrato de EHA de C. xanthocarpa, misoprostol $(0,1 \mathrm{mg} / \mathrm{kg})$ e controle $(1 \mathrm{~mL} / \mathrm{kg})$.

\begin{tabular}{llll}
\hline \hline & & \multicolumn{2}{c}{ Tratados } \\
\cline { 3 - 4 } Ulceração & Controle & EHA & misoprostol \\
\hline \multirow{2}{*}{ Nível I } & $6,455 \pm 0,8242$ & $8,091 \pm 1,254$ & $13,100 \pm 2,702^{\star}$ \\
\hline \hline
\end{tabular}

Os resultados representam a média \pm epm. $N=10$

${ }^{*} p<0,05=$ resultado significativo comparado com o controle.

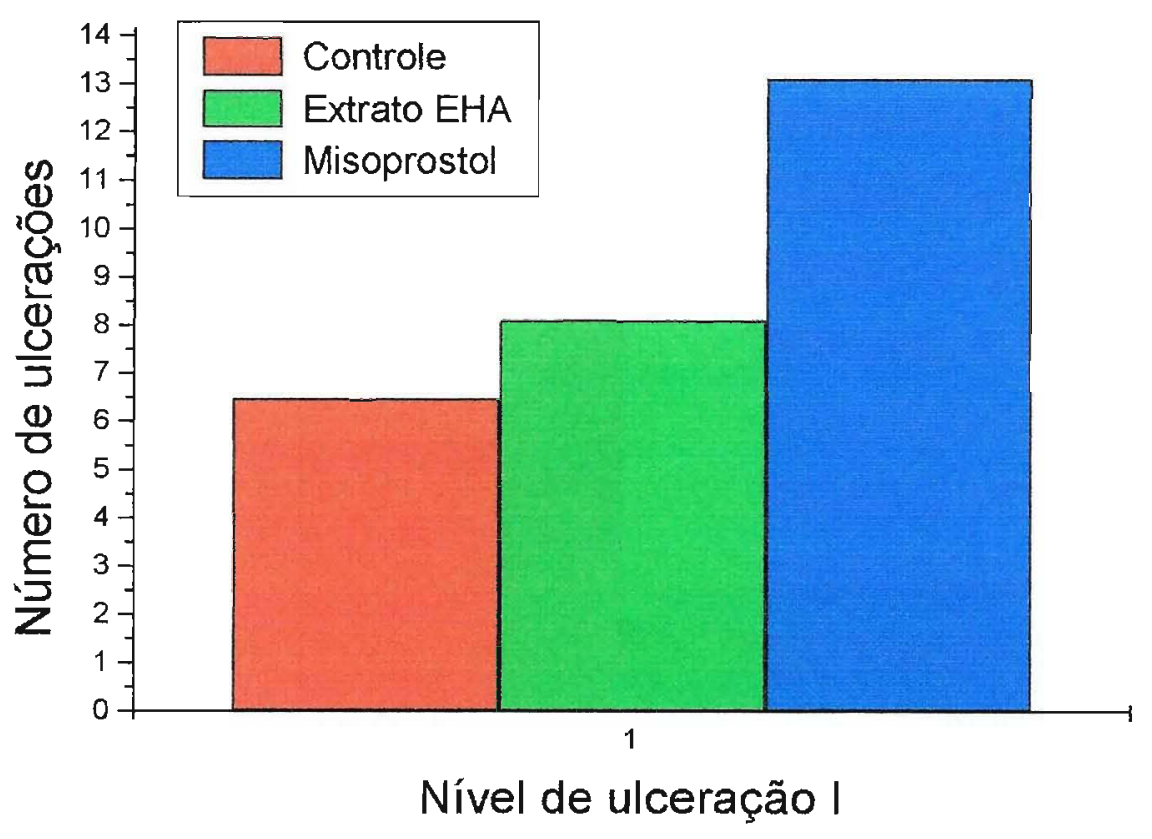

Figura 45. Médias do número de ulcerações do nível l, no grupo de animais controle e tratados por via oral com extrato EHA de C. xanthocarpa e padrão misoprostol. 
Tabela 27. Média do número de ulcerações do nível II induzidas por ácido clorídrico 0,3M em etanol, nos grupos de animais tratados por via oral com 400 $\mathrm{mg} / \mathrm{kg}$ do extrato de EHA de C. xanthocarpa, misoprostol $(0,1 \mathrm{mg} / \mathrm{kg})$ e controle $(1 \mathrm{~mL} / \mathrm{kg})$

\begin{tabular}{llll}
\hline \hline & & \multicolumn{2}{c}{ Tratados } \\
\cline { 3 - 4 } Ulceração & Controle & EHA & misoprostol \\
\hline \multirow{2}{*}{ Nivel II } & $12,545 \pm 1,851$ & $4,000 \pm 0,852^{*}$ & $4,400 \pm 0,718^{*}$ \\
\hline \hline
\end{tabular}

Os resultados representam a média \pm epm. $\mathrm{N}=10$

${ }^{*} p<0,001=$ resultado muito significativo comparado com o controle

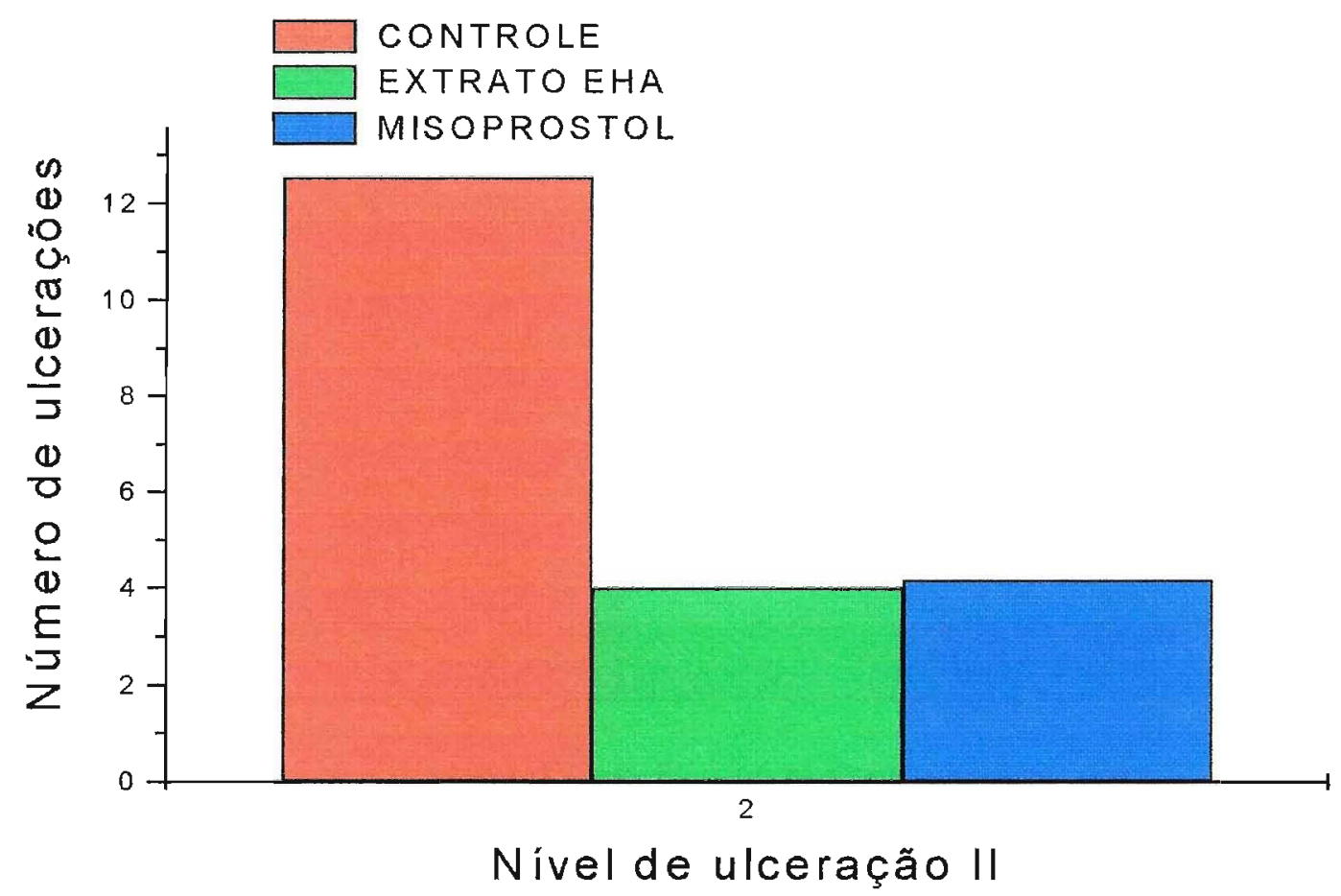

Figura 46. Representação gráfica das médias dos números de ulcerações do nivel II, do grupo de animais controle e tratados por via oral com EHA de C. xanthocarpa, e padrão de misoprostol 
Tabela 28. Média do número do nível III, induzidas por acido clorídrico $0,3 \mathrm{M}$ em etanol, nos grupos de animais tratados por via oral com $40 \mathrm{mg} / \mathrm{kg}$ do extrato de EHA de C. xanthocarpa, misoprostol $(0,1 \mathrm{mg} / \mathrm{kg})$ e controle $(1 \mathrm{~mL} / \mathrm{kg})$.

\begin{tabular}{llll}
\hline \hline \multirow{2}{*}{ Ulceração } & Controle & EHA & misoprostol \\
\cline { 3 - 4 } Nivel III & $36,27 \pm 4,87$ & $8,18 \pm 4,16^{*}$ & $4,5 \pm 1,56^{*}$ \\
\hline \hline
\end{tabular}

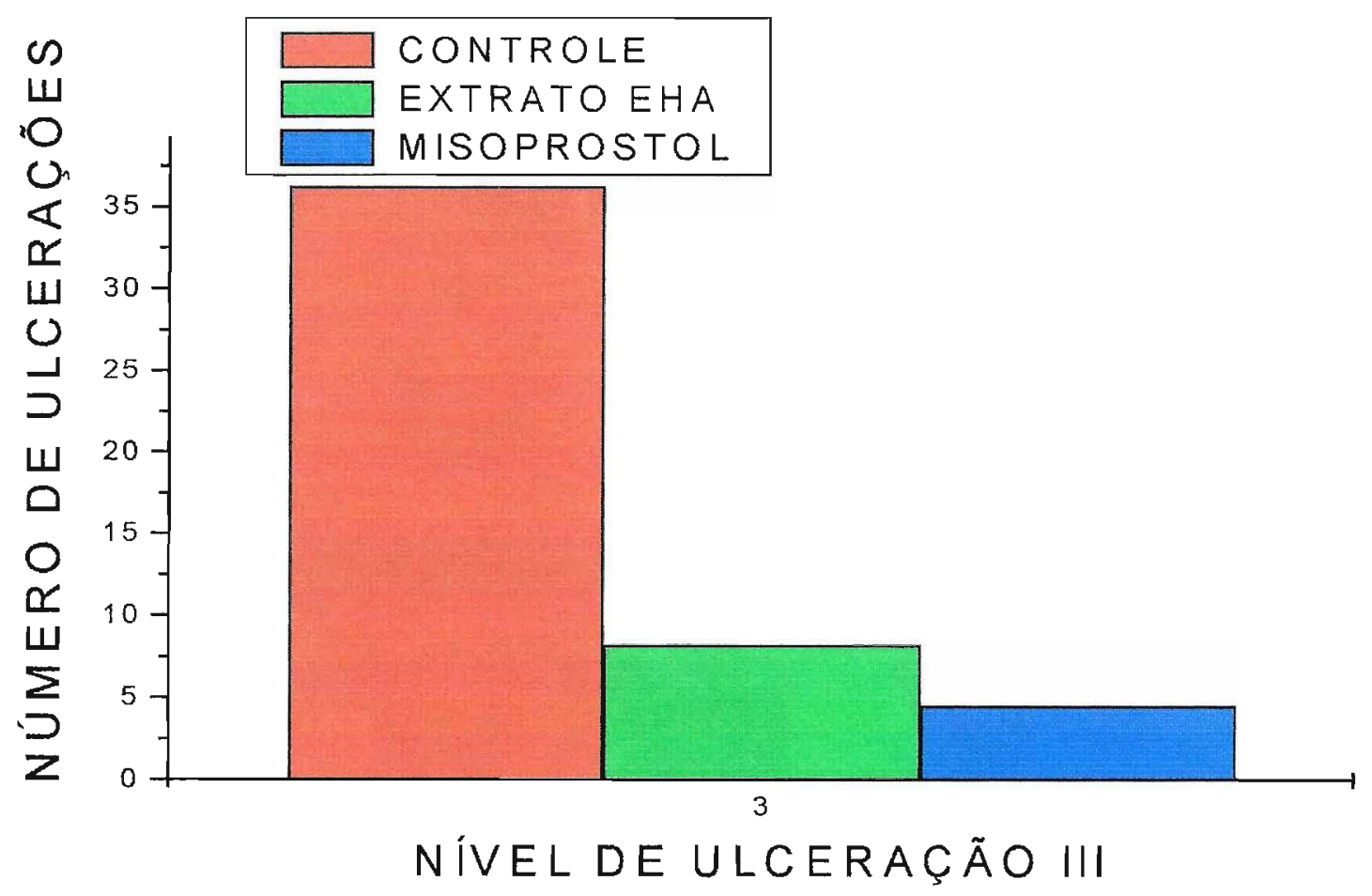

Figura 47. Médias de ulcerações do nível III, do grupo de animais controle e tratados por via oral com EHA de C. xanthocarpa, e padrão de misoprostol 


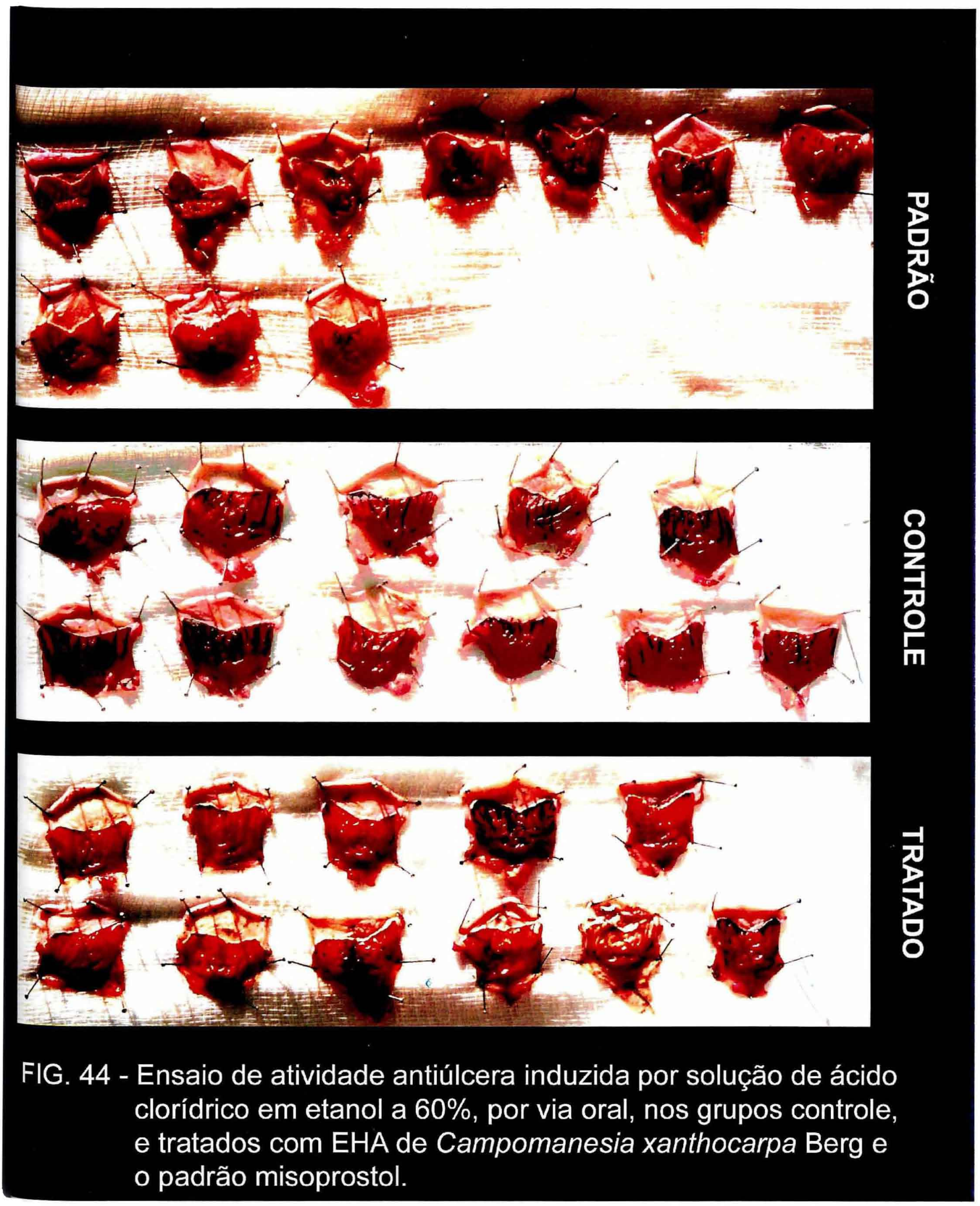




\subsubsection{Avaliação da capacidade antioxidante}

\subsubsection{Cromatografia em camada delgada}

Os resultados obtidos na pesquisa de substâncias antioxidantes, por cromatografia em camada delgada segundo PRATT e MILLER (1984), são mostrados nas tabelas 29 e 30 .

Tabela 29. Análise cromatográfica, em camada delgada (Sistema 6) de substâncias antioxidantes, da droga vegetal, do extrato EHA de C. xanthocarpa e das soluções metanólicas a $0,05 \%$ das substâncias químicas de referência (SQR) quercetina, rutina, crisina, apigenina e ácido clorogênico, como revelador o reativo $\beta$-caroteno em solução 1:1 de clorofórmio e etanol.

\begin{tabular}{cccccc}
\hline \hline Cor & Forma & hRf & $\begin{array}{c}\text { Droga } \\
\text { Vegetal }\end{array}$ & EHA & SQR \\
\hline Amarelo escuro & arredondada & 3 & - & - & Rutina++ \\
Amarelo escuro & arredondada & 4,6 & + & ++ & - \\
Amarelo escuro & arredondada & 6 & ++ & ++ & - \\
Amarelo claro & arredondada & 15 & + & ++ & - \\
Amarelo escuro & arredondada & 46 & - & - & Ac. clorogênico+ \\
Amarelo escuro & arredondada & 54 & - & - & quercetina++ \\
Amarelo escuro & arredondada & 60 & - & - & Apigenina++ \\
Amarelo escuro & arredondada & 70 & - & - & Crisina++ \\
Amarelo escuro & arredondada & 96 & ++ & +++ & - \\
\hline \hline
\end{tabular}

Soluções metanólicas a $0,2 \%$ da droga e do extrato EHA de C. xanthocarpa; Intensidades: $(-)$ - ausente; $(+)$ - fraca; $(++)$ - média; $(+++)$ - forte; 
Tabela 30. Análise cromatográfica em camada delgada (Sistema 7) de substâncias antioxidantes, da droga vegetal, do extrato EHA de C. xanthocarpa, e das soluções metanólicas a $0,05 \%$ das.substâncias químicas de referência (SQR) - rutina e quercetina, como revelador o reativo $\beta$-caroteno em solução $1: 1$ de clorofórmio e etanol.

\begin{tabular}{|c|c|c|c|c|c|}
\hline Cor & Forma & hRf & $\begin{array}{c}\text { Droga } \\
\text { Vegetal }\end{array}$ & EHA & SQR \\
\hline $\begin{array}{l}\text { Amarelo } \\
\text { alaranjado }\end{array}$ & arredondada & 61 & ++ & ++ & - \\
\hline $\begin{array}{l}\text { Amarelo } \\
\text { alaranjado }\end{array}$ & arredondada & 74 & ++ & +++ & - \\
\hline $\begin{array}{l}\text { Amarelo } \\
\text { alaranjado }\end{array}$ & arredondada & 83 & ++ & +++ & - \\
\hline $\begin{array}{l}\text { Amarelo } \\
\text { alaranjado }\end{array}$ & arredondada & 92 & ++ & +++ & - \\
\hline $\begin{array}{l}\text { Amarelo } \\
\text { alaranjado }\end{array}$ & arredondada & 97 & ++ & +++ & - \\
\hline $\begin{array}{l}\text { Amarelo } \\
\text { alaranjado }\end{array}$ & arredondada & 13 & - & - & Rutina+++ \\
\hline Amarelo alarnjado & Arredondada & 100 & - & - & Quercetina++ \\
\hline
\end{tabular}

Soluções metanólicas a $0,2 \%$ da droga e do extrato EHA de $C$. xanthocarpa. Intensidades: $(-)-$ ausente; $(+)$ - fraca; $(++)$ - média; $(+++)$ - forte. 
Tabela 31. Análise cromatográfica em camada delgada (Sistema 8) de substâncias antioxidantes, da droga vegetal e do extrato EHA de C. xanthocarpa e da solução metanólica a $0,05 \%$ da substância química de referência (SQR) quercetina, como revelador o reativo $\beta$-caroteno em solução 1:1 de clorofórmio e etanol.

\begin{tabular}{clcccc}
\hline \hline Cor & Forma & hRF & $\begin{array}{c}\text { Droga } \\
\text { Vegetal }\end{array}$ & EHA & SQR \\
\hline laranjado & alongada & 16 & - & - & Quercetina +++ \\
laranjado & arredondada & 50 & ++ & +++ & - \\
laranjado & arredondada & 54 & ++ & +++ & - \\
\hline \hline
\end{tabular}

Soluções metanólicas a $0,2 \%$ da droga vegetal e do extrato EHA de $C$. xanthocarpa. Intensidades: $(-)$ - ausente; $(+)-$ fraca; $(++)$ - média; $(+++)$-forte. 


\subsubsection{Medida de produção de malonildialdeido (MDA)}

A capacidade antioxidante do extrato EHA de C. xanthocarpa, foi avaliada através da produção de malonildialdeído (MDA), na lipoperoxidação espontânea de homogenato de cérebro de ratos. Os valores representam a média de 4 determinações de substâncias reagentes com ácido tiobarbitúrico (TBARS) e são apresentados na tabela $n^{\circ} 32$ e figura $n^{\circ} 48$.

Tabela 32. Capacidade antioxidante (CaOx\%) do extrato EHA de C. xanthocarpa na lipoperoxidação espontânea do homogenato de cérebro de rato.

\begin{tabular}{lccc}
$\begin{array}{c}\text { Concentraçäo do EHA } \\
(\mu \mathrm{g} / \mathrm{mL})\end{array}$ & $\begin{array}{c}\text { Capacidade antioxidante } \\
\text { CAOx }(\%)\end{array}$ & $\begin{array}{c}1 / \text { conc. do EHA } \\
(\mu \mathrm{g} / \mathrm{mL})\end{array}$ & \begin{tabular}{c}
$1 / \mathrm{CAOx} \%$ \\
\hline 1,2500
\end{tabular} \\
\hline & $98,1390 \pm 0,4368$ & 0,8000 & 0,0102 \\
0,4166 & $54,4100 \pm 1,8150$ & 2,4000 & 0,0184 \\
0,2083 & $45,7500 \pm 0,7235$ & 4,8007 & 0,0218 \\
0,1050 & $20,0700 \pm 3,0200$ & 9,5200 & 0,0498 \\
0,0500 & $5,7200 \pm 0,5190$ & 20,000 & 0,1748
\end{tabular}


Figura 48. Capacidade antioxidante do extrato EHA de C. xanthocarpa, determinação da linearidade, regressão linear e concentração necessária para atingir $50 \%$ da capacidade antioxidante (IC50).

- - Reta da capacidade antioxidante do EHA Linearidade da capacidade antioxidante do EHA $95 \%$ limite de confiança superior 95\% limite de confiança inferior

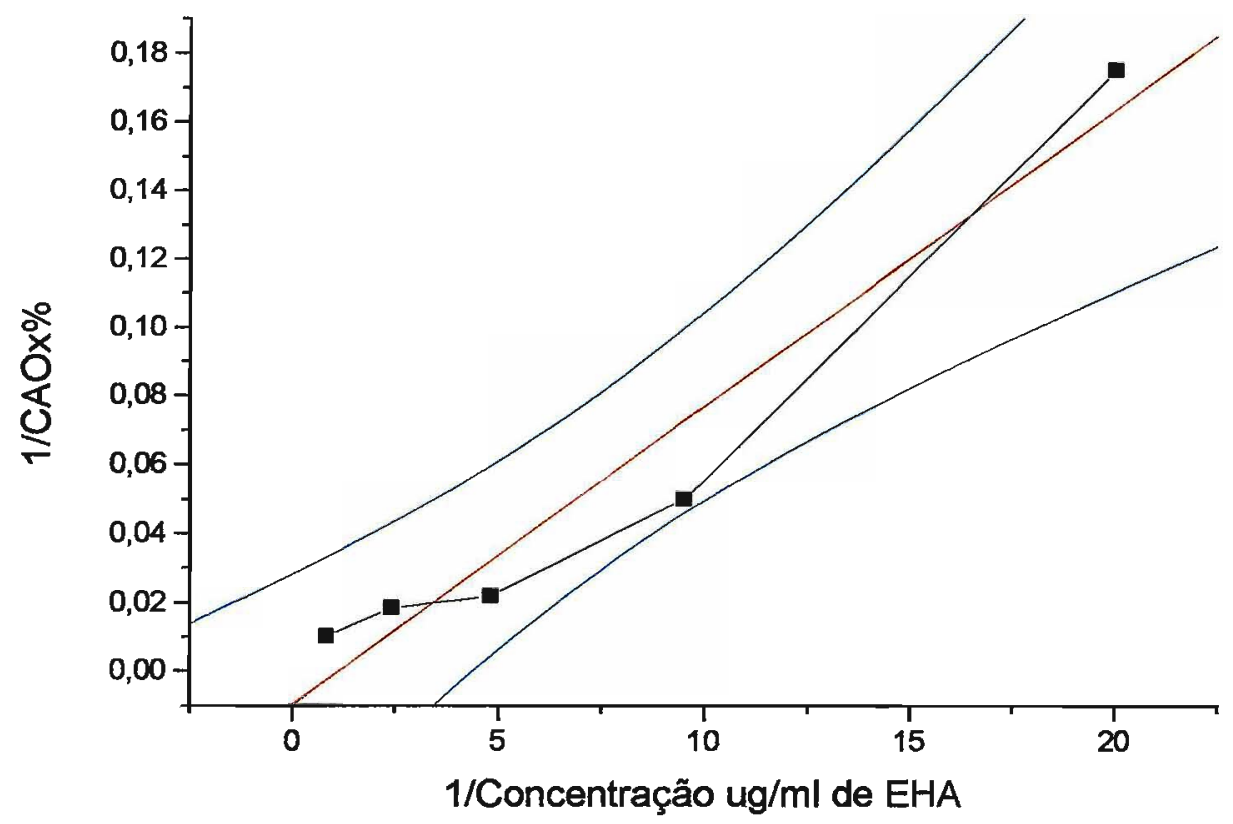

Equação da reta $: Y=A+B * X$

Parametros Valor Erro

A $\quad-0,10992 \quad 0,01192$

B $\quad 0,00865 \quad 0,00117$

Regresão linear: Dı9737l; SD: Qı01805; Número de ensaios: 5

Cálculo de IC50. (concentração necessária de EHA para atingir $50 \%$ da capacidade antioxidante) $: Y=1 / 50=-0,00992+0,00865 * X$

$\mathrm{Q}_{1 / 2}$ ou $\mathrm{IC} 50=0,2891 \mu \mathrm{g} / \mathrm{mL}$ 
5.3.5.3. Avaliação do efeito do extrato EHA de C. xanthocarpa na cinética de oxidação de Lipoproteinas de baixa densidade (LDL) induzida por sulfato de cobre.

A figura 49 mostra o aumento progressivo do tempo de iniciação da oxidação da LDL induzida por sulfato de cobre em presença de concentrações progressivas de extrato de EHA de C. xanthocarpa.

Formação de

Dienos conjugados

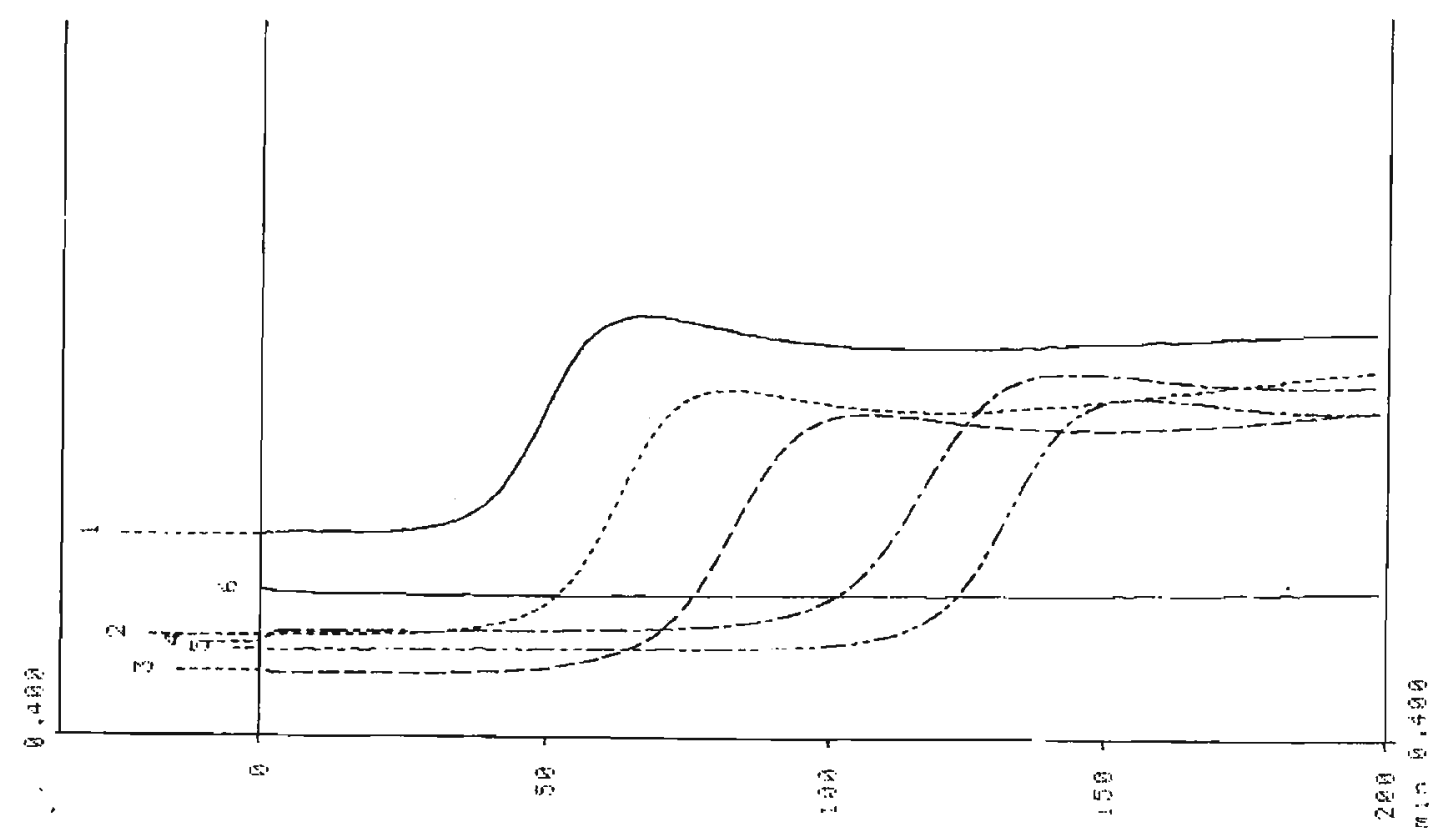

Tempo (minutos)

Figura 49 . Oxidação de lipoproteinas de baixa densidade ( $L D L$ ) induzida por sulfato de cobre, monitorada a $234 \mathrm{~nm}$ durante 200 minutos. As curvas $\mathrm{N}^{0} 1$, $2,3,4,5$ e 6 apresentam os tempos de iniciação da formação de dienos conjugados nas concentrações $0 ; 0,150 ; 0,312 ; 0,625 ; 1,250 ;$ e $2,500 \mu \mathrm{g} / \mathrm{mL}$ do extrato EHA de C. xanthocarpa, no meio de reação. 
4 Análise da cinética no processo de oxidação de lipoproteínas de baixa densidade (LDL)

A análise da cinética de oxidação de lipoproteínas de baixa densidade (LDL) foi realizada considerando-se os dois componentes do processo: "Lagtime" e "Peak -time". A figura 50 apresenta a oxidação da LDL induzida por sulfato de cobre na ausência do extrato de EHA de C. xanthocarpa.

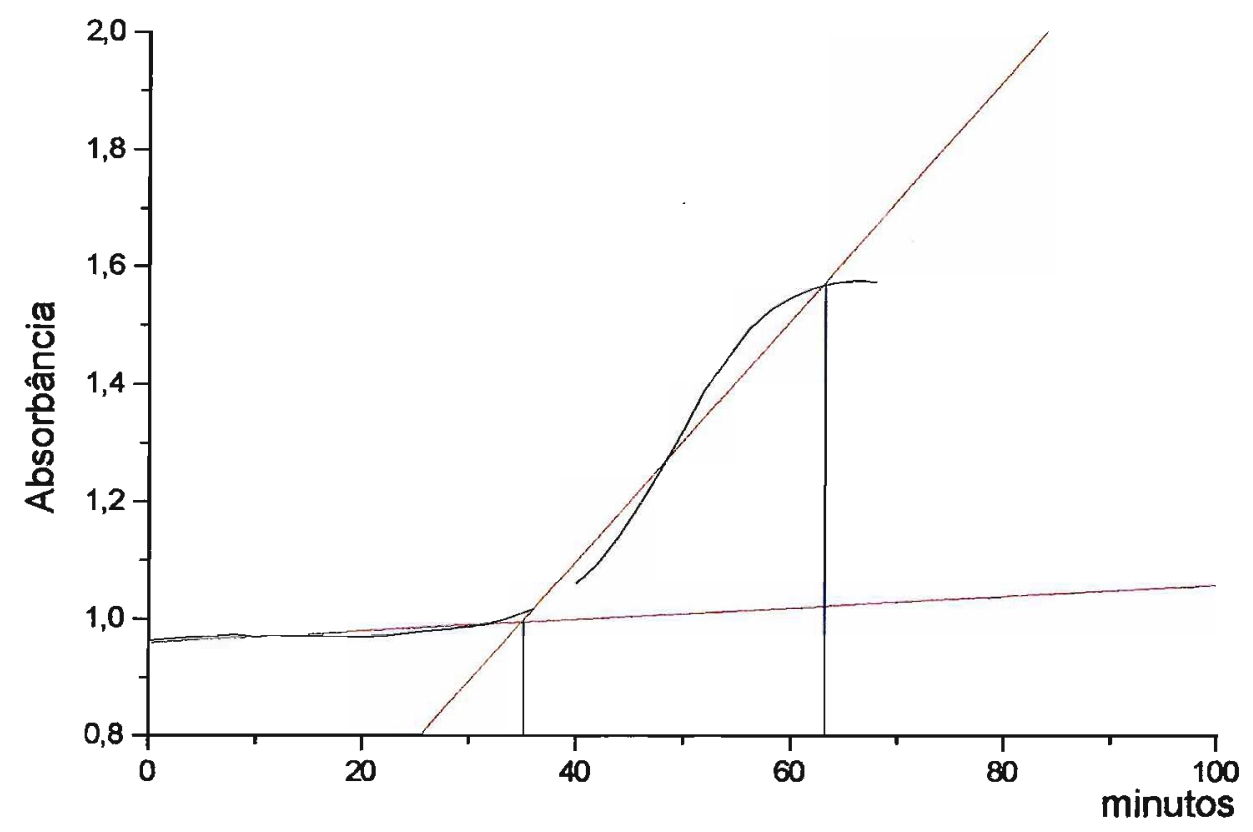

Figura 50. Oxidação de LDL induzida por sulfato de cobre, na ausência de extrato EHA de C. xanthocarpa. Determinação de "Lag-time" e "Peak-time", segundo ESTERBAUER e cols. (1992)

"Lag-time" $=33,7377$

"Peak-time" $=64,5401$ 
A figura 51 mostra a cinética da oxidação de lipoproteínas de baixa densidade (LDL) induzida por sulfato de cobre na presença de $0,150 \mu \mathrm{g} / \mathrm{mL}$ de EHA de C. xanthocarpa

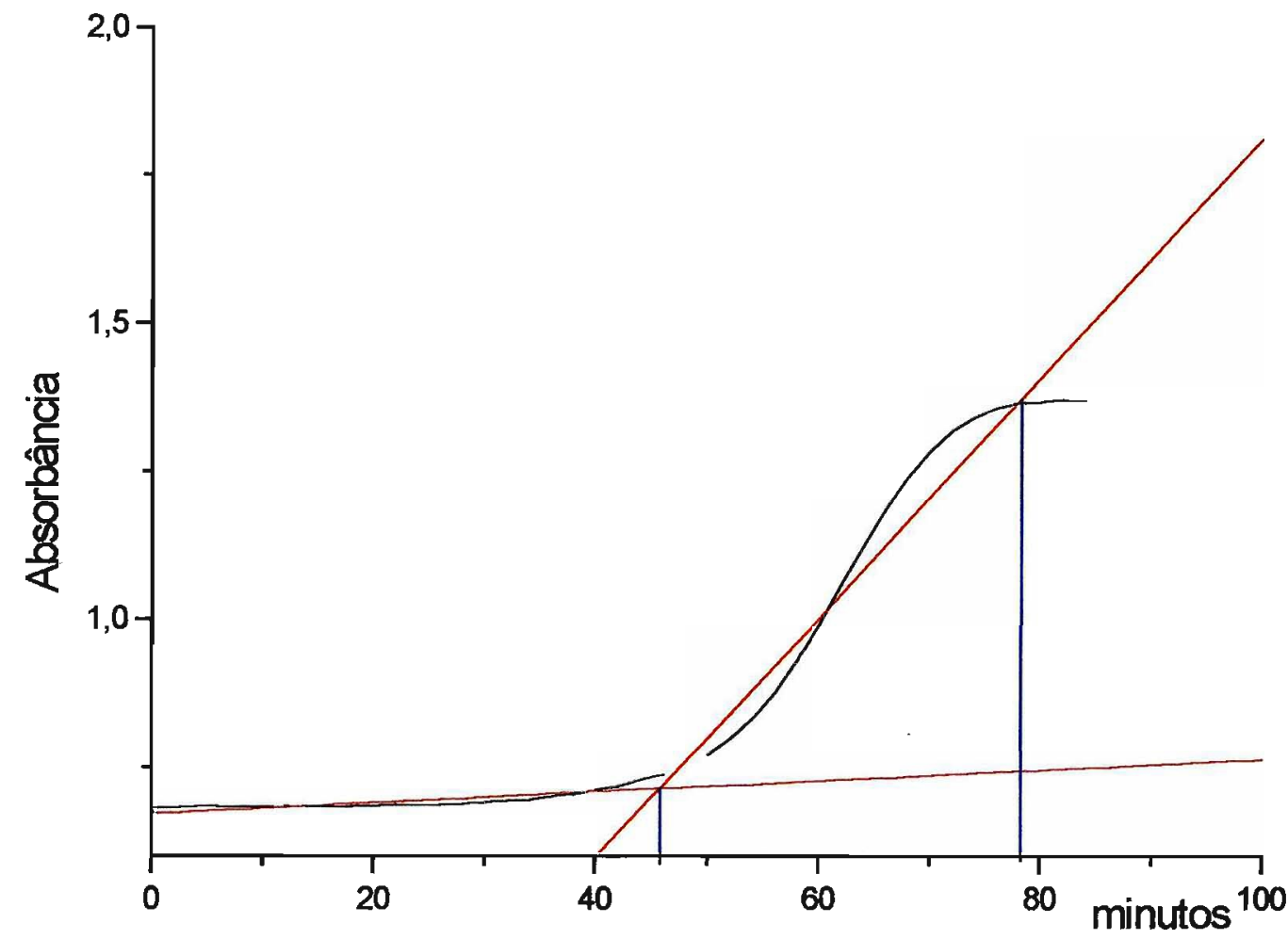

Figura 51. Oxidação de LDL induzida por sulfato de cobre, a $234 \mathrm{~nm}$, na presença de $0,150 \mu \mathrm{g} / \mathrm{mL}$ de EHA de C. xanthocarpa. Determinação de "Lag-time" e "Peak-time", segundo ESTERBAUER e cols (1992).

“Lag-time" = 45,7925

"Peak-time" $=78,9041$ 
A figura 52 mostra a cinética da oxidação de lipoproteínas de baixa densidade (LDL) induzida por sulfato de cobre na presença de $0,312 \mu \mathrm{g} / \mathrm{mL}$ de EHA de C. xanthocarpa.

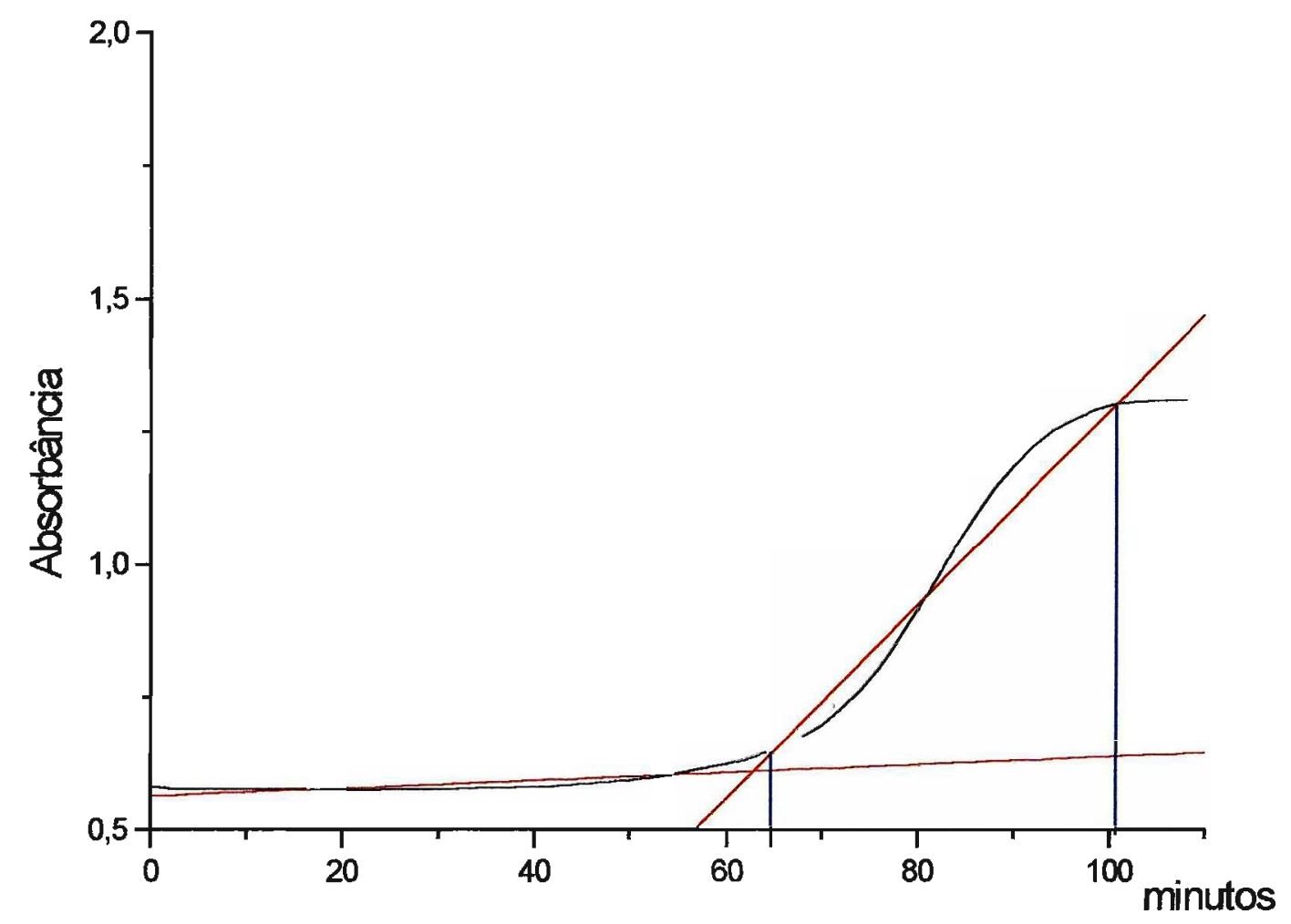

Figura.52. Oxidação de LDL induzida por sulfato de cobre, a $234 \mathrm{~nm}$, na presença de $0,312 \mu \mathrm{g} / \mathrm{mL}$ de EHA de $C$. xanthocarpa. Determinação de "Lagtime" e "Peak-time", segundo ESTERBAUER e cols. (1992)

$$
\begin{aligned}
& \text { "Lag-time" }=65,2250 \\
& \text { "Peak-time" }=100,958
\end{aligned}
$$


O gráfico 53 mostra a cinética da oxidação de lipoproteínas de baixa densidade (LDL) induzida por sulfato de cobre na presença de $0,625 \mu \mathrm{g} / \mathrm{mL}$ de EHA de C. xanthocarpa.

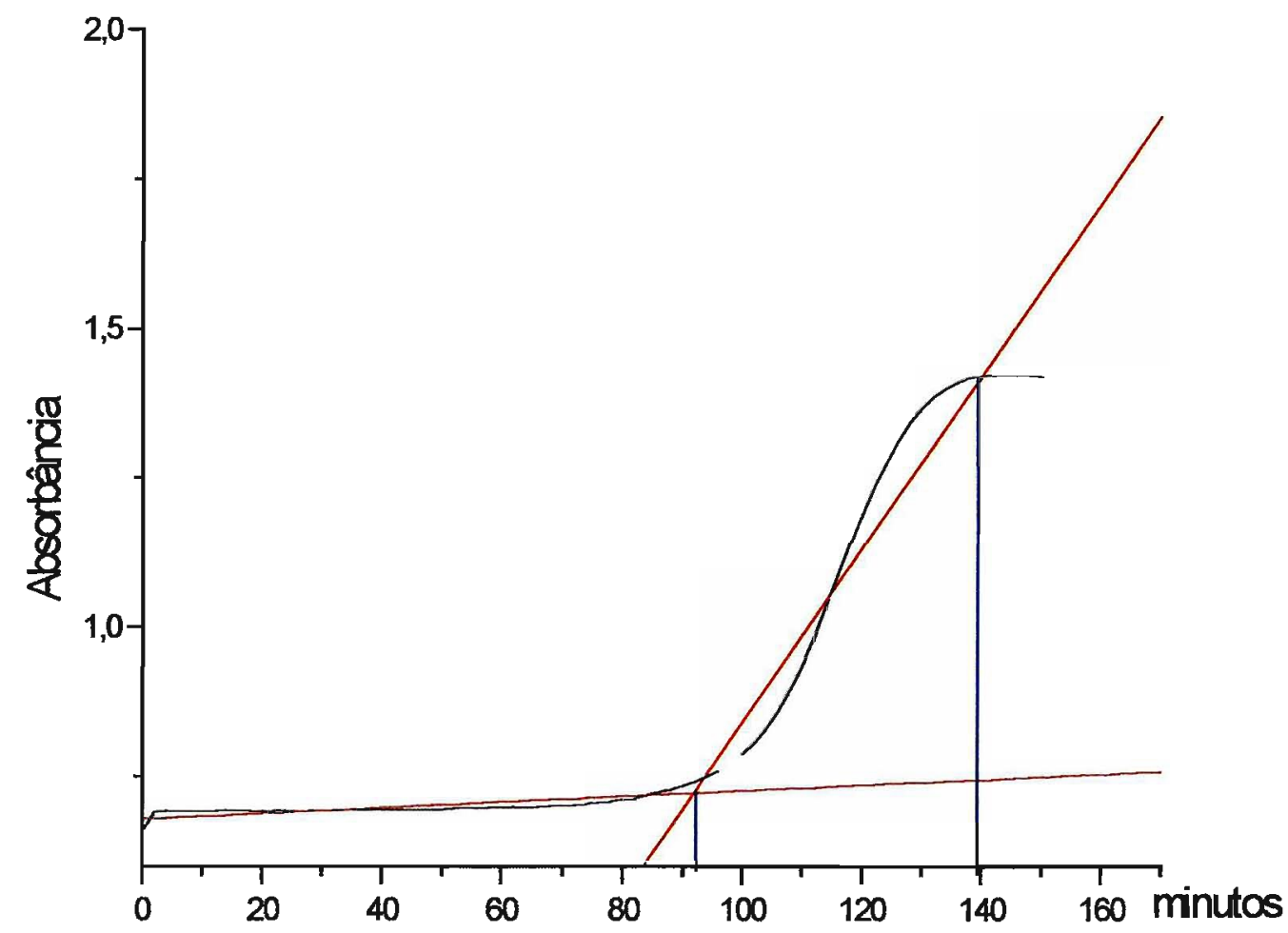

Figura.53. Oxidação de LDL induzida por sulfato de cobre, a $234 \mathrm{~nm}$, na presença de $0,625 \mu \mathrm{g} / \mathrm{mL}$ de EHA de $C$. xanthocarpa. Determinação de "Lagtime" e "Peak-time", segundo ESTERBAUER e cols. (1992).

"Lag-time" = 92,2857

"Peak-time" = 139,4598 
O figura 54 mostra a cinética da oxidação de lipoproteínas de baixa densidade (LDL) induzida por sulfato de cobre na presença de $1,250 \mu \mathrm{g} / \mathrm{mL}$ de EHA de C. xanthocarpa.

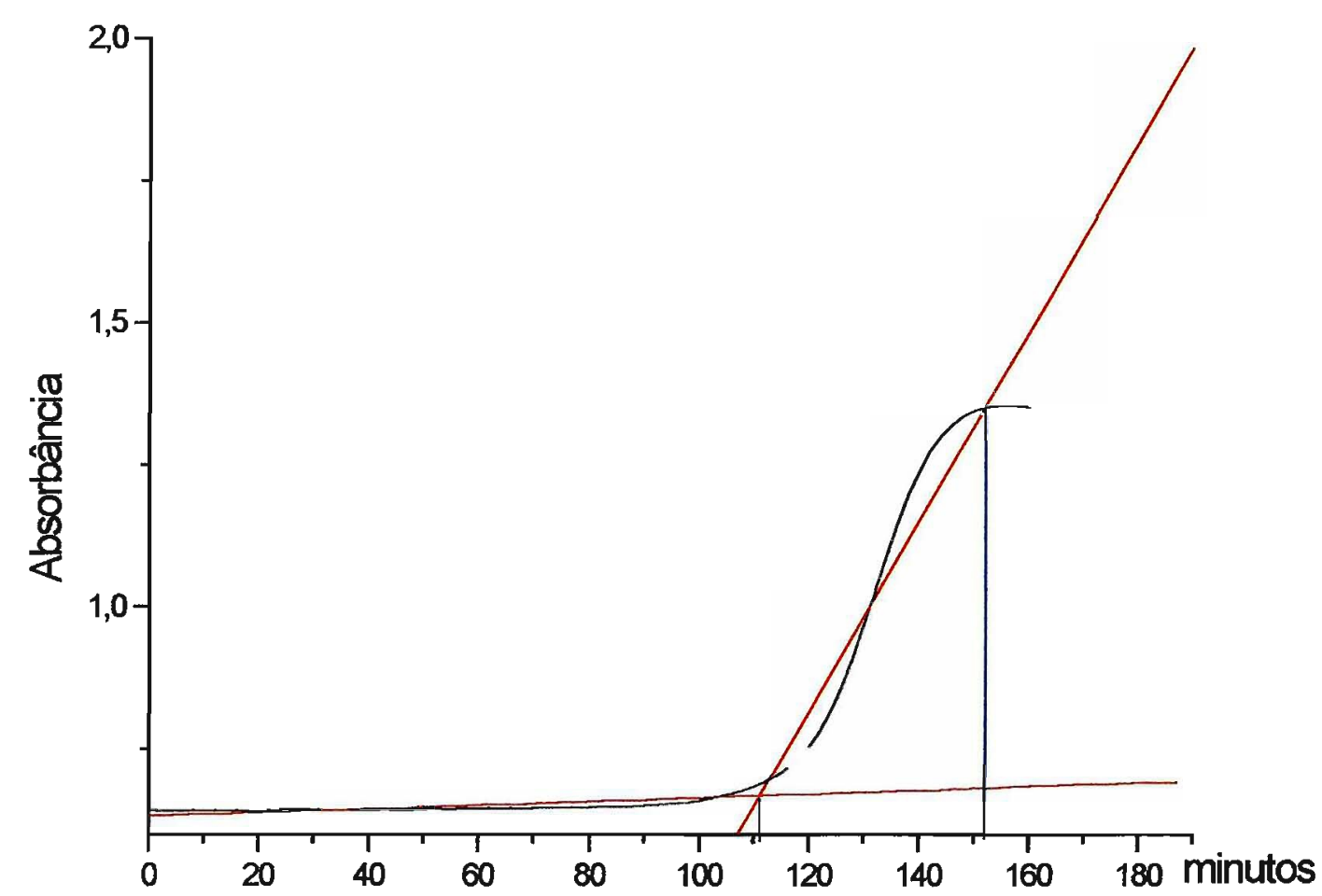

Figura 54. Oxidação de LDL induzida por sulfato de cobre, a $234 \mathrm{~nm}$, na presença de $1,250 \mu \mathrm{g} / \mathrm{mL}$ de EHA de $C$. xanthocarpa. Determinação de "Lagtime" e "Peak-time", segundo ESTERBAUER e cols (1992).

$$
\begin{aligned}
& \text { "Lag-time" }=111,248 \\
& \text { "Peak-time" =152, } 4050
\end{aligned}
$$


A tabela 33 e a figura 55 apresentam os valores de "Lag-time" na cinética de oxidação de $L D L$, na presença de concentrações de $0 ; 0,15 ; 0,312$; 0,626 e $1,250 \mu \mathrm{g} / \mathrm{mL}$ de extrato EHA de $C$. xanthocarpa.

Tabela 33 . Valores de "Lag-time" obtidos segundo ESTERBAUER e cols (1992), expressando a cinética de oxidação de LDL induzida por sulfato de cobre, a $234 \mathrm{~nm}$, na presença de concentrações progressivas de EHA de C. xanthocarpa

\begin{tabular}{cl}
\hline \hline $\begin{array}{c}\text { Concentração de EHA C. xanthocarpa } \\
\mu \mathrm{g} / \mathrm{mL}\end{array}$ & $\begin{array}{l}\text { "Lag-time" } \\
\text { minutos }\end{array}$ \\
\hline- & 33,23 \\
0,15 & 45,29 \\
0,312 & 65,22 \\
0,625 & 92,28 \\
1,25 & 111,24 \\
\hline \hline
\end{tabular}

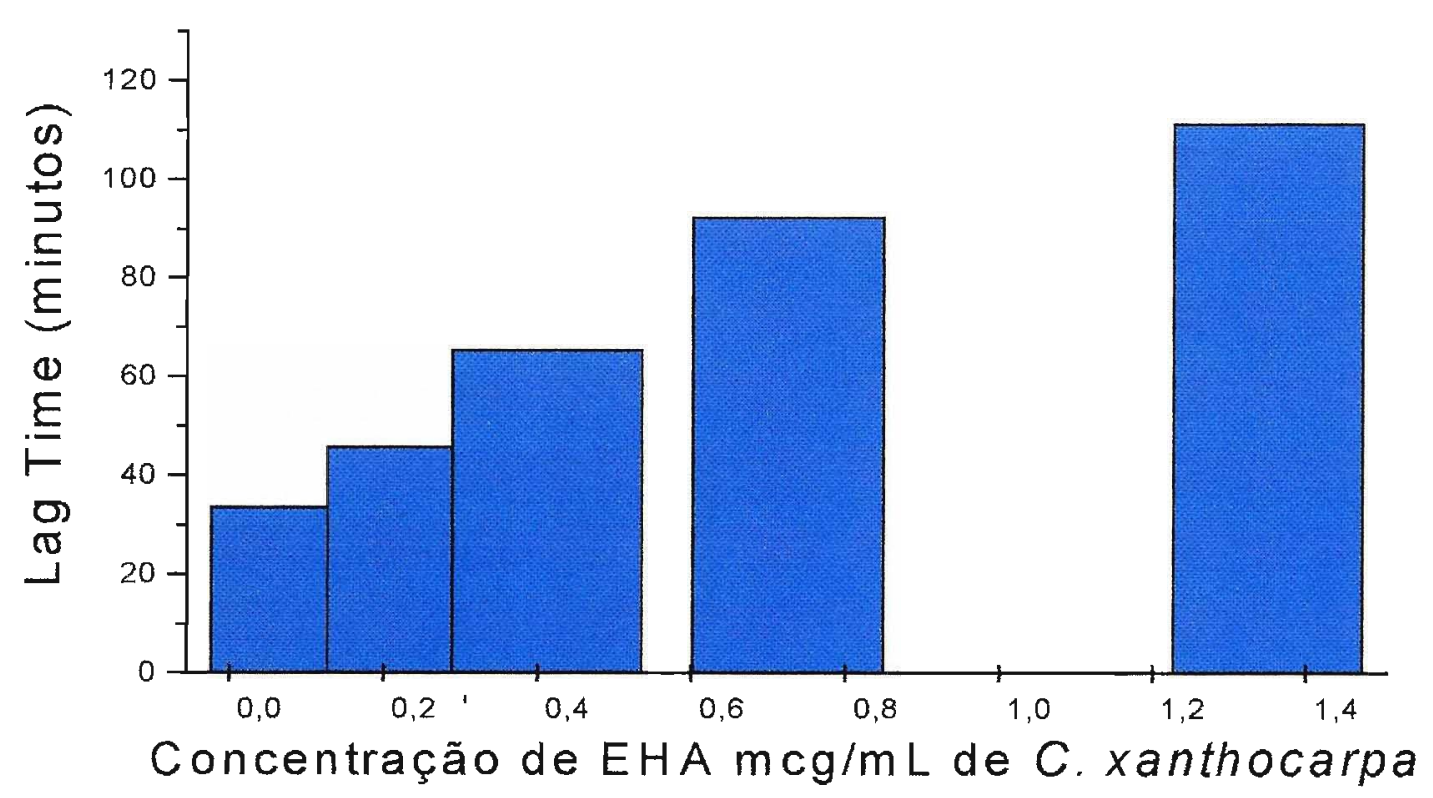

Figura 55. Valores de "Lag-time" na presença de concentrações progresivas de EHA de C. xanthocarpa. 
A tabela 34 e a figura 56 apresentam os valores de "Peak-time" na cinética de oxidação de LDL, na presença de concentrações de $0 ; 0,15 ; 0,312$; 0,626 e 1,25 $\mu \mathrm{g} / \mathrm{mL}$ de extrato EHA de $C$. xanthocarpa.

Tabela 34.Valores de "Peak-time" obtidos segundo ESTERBAUER e cols. (1992), expressando a cinética de oxidação de Lipoproteínas de Baixa Densidade (LDL) induzida por sulfato de cobre a $234 \mathrm{~nm}$, na presença de concentrações progressivas de EHA de $C$. xanthocarpa

\begin{tabular}{cl}
\hline \hline $\begin{array}{c}\text { Concentração de EHA C. xanthocarpa } \\
\mu \mathrm{g} / \mathrm{mL}\end{array}$ & $\begin{array}{l}\text { "Peak-time" } \\
\text { minutos }\end{array}$ \\
\hline- & 65,54 \\
0,15 & 78,54 \\
0,312 & 100,35 \\
0,625 & 139,45 \\
1,25 & 152,40 \\
\hline \hline
\end{tabular}

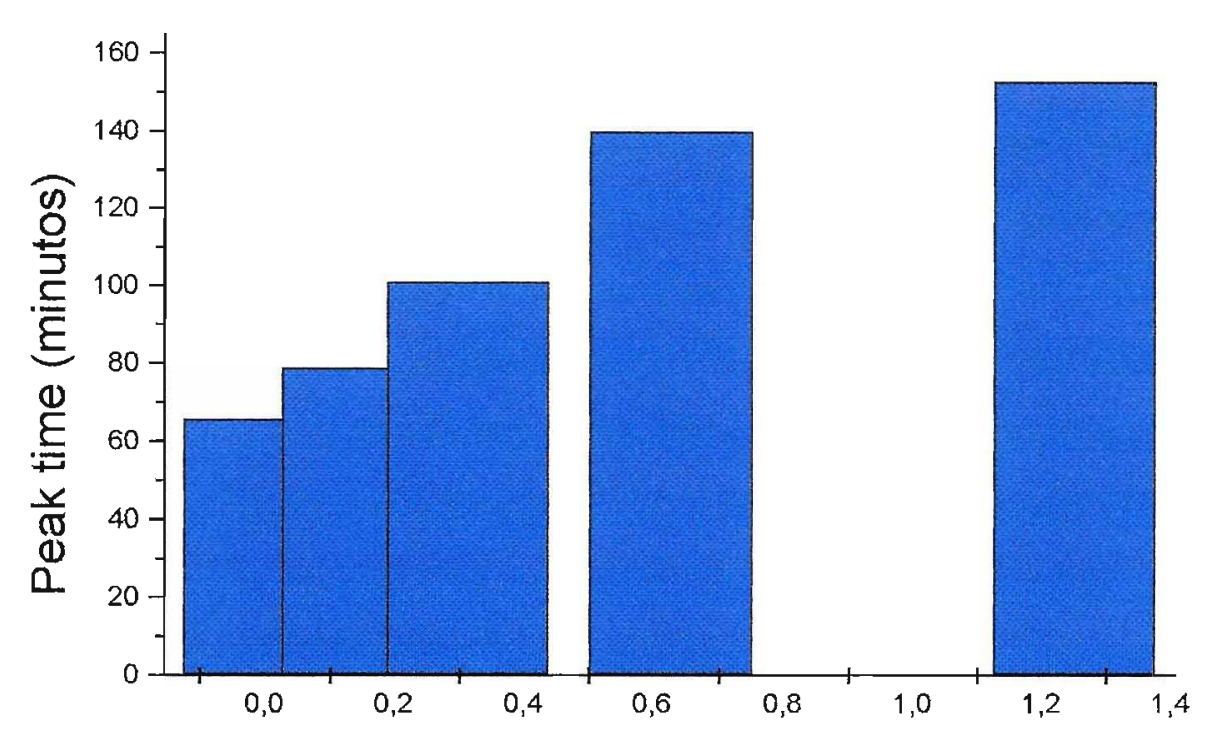

Concentração em $\mathrm{mcg} / \mathrm{mL}$ de EHA de C. xanthocarpa

Figura 56. Valores de "Peak-time" nas concentrações progressivas de C. xanthocarpa. 


\section{DISCUSSÃO}

\subsection{Generalidades}

O potencial dos metabólitos secundários das plantas superiores como fonte de novos fármacos é relativamente pouco explorado. Os metabólitos secundários das plantas despertam grande interesse seja pelo aspecto ecológico, químico como farmacológico (CRAGG e cols., 1997). Estima-se que existam cerca de 250 a 500 mil espécies vegetais, das quais apenas pequena parcela tem sido estudada quimicamente e uma parcela ainda menor tem sido objeto de estudos farmacológicos (KOROLKOVAS e cols.,1988, SOUZA BRITO, e cols., 1993).

No Brasil, o alto custo dos medicamentos industrializados, o difícil acesso da população à assistência médica e farmacêutica, bem como a tendência do consumo de produtos de origem natural são fatores que têm contribuído para o aumento de consumo de fitoterápicos nos últimos anos (SIMÕES, 1989).

A família Myrtaceae destaca-se pela presença de representantes com uso indistinto na alimentação e no tratamento de doenças. Diversas espécies apresentam emprego terapêutico, principalmente no controle da gota e do diabete. Alguns estudos farmacológicos apóiam esses usos populares. Espécies de Eugenia, Psidium e Plinia demonstraram atividade antigota (THEODOLUZ e cols., 1988). O extrato hidroalcoólico de Myrtus communis mostrou-se ativo como hipoglicemiante (ELFELLAH e cols., 1984).

Poucas plantas medicinais, seus extratos ou substâncias farmacologicamente ativas possuem dados de segurança e eficácia. Durante a $4^{a}$ Conferência Internacional de Agentes Reguladores de Drogas (ICDRA), realizada em Tóquio em 1986, delegou-se à Organização Mundial da Saúde (OMS), o estabelecimento de especificações internacionais para as plantas medicinais e suas preparações simples. A $6^{\mathbf{a}}$ ICDRA realizada em Otawa, em 1991, adotou essas especificações e a OMS publicou o primeiro volume com 28 monografias 
(OMS, 1997). Neste aspecto, diversos resultados obtidos nesta dissertação são inéditos e podem contribuir na elaboração de monografia oficial de folhas de $C$. xanthocarpa Berg.

\subsection{Aspectos botânicos}

$\mathrm{Na}$ diagnose de drogas vegetais, a descrição macroscópica mostra importância na análise inicial da matéria-prima, permitindo a detecção de adulterações ou falsificações. De modo geral, as folhas mostram variação neste item. KAWASAKI e LANDRUM (1997) estudando Campomanesia phaea citam forma, consistência, superfície e indumento próximos aos observados em $C$. xanthocarpa.

Os caracteres anatômicos foliares, principalmente os relacionados à epiderme, tem sido valorizados em estudos taxonômicos de Myrtaceae (KHATIJAH e cols., 1992, FONTENELLE e cols., 1994).

FONTENELLE e cols. (1994) estudando folhas de Eugenia, verificaram em 8 espécies, as paredes anticlinais da epiderme, de forma sinuosa e, reta em 3 espécies. Em algumas destas plantas, observaram variações no contorno da parede anticlinal, quando comparada a epidermes da superfície abaxial e adaxial, podendo apresentar-se sinuoso em uma das faces e reta na outra.

Em C. xanthocarpa, as células epidérmicas da face adaxial apresentam-se retas e as da abaxial, comparativamente sinuosas ( Figs. 13 a 15).

Os mesmos autores descrevem, células distintas ("overlying cells"), de disposição radial, em ambas as faces, sobre as cavidades secretoras observadas no mesofilo de espécies de Eugenia. Estas células podem ocorrer isoladas, em pares ou em grupos de três. Quando encontram-se aos pares, a parede celular comissural pode apresentar-se reta, sinuosa ou forma de zig-zag.

Em C. xanthocarpa, foram observadas "overlying cells" em número de 2, com a parede comissural em forma de zig-zag, "S" e curva. (Fig.16 e 17). 
JORGE (1992) descreve como sendo a parede aproximadamente reta e provida de pequenos dentes na sua parte central.

FERRI (1971) estudando a epiderme foliar de espécies de Myrtaceae, apontou as folhas como hipoestomáticas.

FONTENELLE e cols. (1994) em sua pesquisa com 11 espécies de Eugenia encontradas no Rio de Janeiro, conclui que 10 apresentaram mesofilo dorsiventral. Todas as espécies estudadas eram hipoestomáticas, providas de estômatos paracíticos, anisocíticos, ciclocíticos e tetracíticos, sendo observados ao mesmo nível das demais células epidérmicas.

Segundo METCALFE e CHALK (1972) os estômatos de Myrtaceae são geralmente anomocíticos, podendo ocorrer os paracíticos em alguns gêneros.

Em C. xanthocarpa foram observadas folhas de mesofilo dorsiventral (Figs. 7 a 10), hipoestomáticas, com estômatos anomocíticos e paracíticos (Figs. 13 a 15), predominando os anomocíticos, localizados ao mesmo nível das demais células epidérmicas. Estes fatos estão em concordância com FERRI (1971), METCALFE e CHALK (1972), FONTENELLE e cols. (1994). JORGE (1992) descreve apenas estômatos paracíticos nesta espécie. Outra característica auxiliar na diagnose é a presença de idioblastos oval-eliptícos, na região do parênquima paliçádico. Estas células destacam-se pelo tamarıho que alcançam até cerca da metade da espessura do mesofilo e pela presença de cristais prismáticos isolados (Figs. 10 e 11). Este fato não foi mencionado por JORGE (1992).

\subsection{Aspectos químicos}

\subsubsection{Triagem fitoquímica e doseamento}

A triagem fitoquímica da droga vegetal e do extrato extrato hidroalcoólico liofilizado a $70 \%$ (EHA) permitiram constatar a presença de flavonóides, esteróides, saponinas e taninos (Tabela 3). A intensidade, seja na coloração como na formação dos precipitados foram relativamente maiores no extrato EHA. O óleo essencial foi estudado apenas na droga vegetal, fato associado ao 
processo de obtenção do extrato EHA. Estes resultados encontram-se em concordância com a análise cromatográfica em camada delgada dos mesmos. Este último ensaio, realizado com as substâncias-padrão disponiveis, evidenciou diversas manchas atribuiveis às diversas classes de compostos (Tabelas 7 e 8) detectados anteriormente por cromatografia em fase gasosa (Tabela 9).

SCHMEDA-HIRSCHMANN (1995) e BAUER (1975) identificaram quercetina, miricetina, quercitrina e rutina em $C$. xanthocarpa. A análise cromatográfica em camada delgada da fração flavonoídica da droga vegetal e do extrato EHA evidenciou 5 manchas, não coincidentes com os padrōes de rutina, quercetina e ácido clorogênico (tabela 6). Na amostra analisada, embora observem-se manchas indicativas da presença de flavonóides e ácido fenólicos, estas não correspondem à algumas das substâncias isoladas por aqueles autores. Este fato pode ser relacionado à variação sazonal de compostos, comum em espécies vegetais e evidencia a importância deste tipo de estudo.

A análise cromatográfica em camada delgada da fração saponínica apresentou 7 manchas coincidentes para a droga vegetal e para o extrato EHA, conforme mostra a tabela 4 . Embora não se encontre na literatura citações de saponinas na família e no gênero, estes dados corroboram a indicação da presença deste grupo de substâncias no ensaio afrogênico inicial (tabela 3). Estas frações saponínicas não apresentaram atividade hemolitica até a concentração de $200 \mathrm{mg} / \mathrm{mL}$. Sua quantificação foi realizada empregando-se método gravimétrico. Embora a técnica mostre limitações relacionadas ao processo de extração e de purificação, não apresentando boa reprodutibilidade e especificidade, mostra valor na avaliação prévia do teor. SHASHI e cols.(1988), descrevem um método de quantificação de saponinas por cromatografia líquida de alta performance, assim como a separação das mesmas, é um método complexo que requer o conhecimento prévio da estrutura química das saponinas.

O teor de saponinas encontrado foi de $16 \mathrm{~g} \%$ no extrato EHA e $6,3 \mathrm{~g} \%$ no pó da droga vegetal.

Os taninos são compostos freqüentemente encontrados na família Myrtaceae e ocorrendo na espécie em estudo foram quantificados. 
Na literatura encontram-se poucos métodos de quantificação de taninos HAGERMAN e cols. (1978) descrevem um método de doseamento através da precipitação de taninos com uma solução padrão de proteina. O complexo tanino-proteína formado é dissolvido em álcali e a leitura efetuada em $510 \mathrm{~nm}$.

A metodologia, utilizada neste estudo, para o doseamento de taninos foi a descrita na Farmacopéia Européia (2001). A técnica apresenta limitações de operacionalização, tais como, as condições de reação e leitura do complexo formado, exatamente após 2 minutos; como vantagem, apresentou linearidade de 0,99966, para as concentrações de 0,5 a 2,0 $\mu \mathrm{g} / \mathrm{mL}$, da substância química de referência - pirogalol. Este dado faz considerá-lo um método bom para o doseamento de polifenóis totais. Os teores de taninos encontrados foram de 8,49 $\pm 0,03 \mathrm{~g} \%$ e de $2,86 \pm 0,01 \mathrm{~g} \%$, para o extrato EHA e para a droga vegetal, respectivamente. Comparando-se estes valores com o teor de $10 \%$ encontrado nas folhas de Psidium guajava (ALMEIDA, 1995), pode-se considerá-lo baixo. Seria necessário testar outros tipos de extração para taninos conforme citam NONAKA e cols. (1987).

O óleo essencial, detectado na triagem fitoquímica, foi quantificado na amostra constituída de folhas frescas coletadas no final da frutificação. O teor obtido foi de $0,11 \%(\mathrm{v} / \mathrm{p})$. O valor encontrado nas folhas frescas de Myrciaria glomerata foi de $0,17 \%$ (v/p), também coletado no final da frutificação (SILVA, 2001, não publicado). Comparativamente observam-se valores próximos nas duas espécies de Myrtaceae.

Este óleo essencial, apresentou como componentes principais linalol $(29,2 \%)$, globulol $(20,17 \%)$, espatulenol $(6,5 \%)$, terpineol $(6,6 \%)$ e limoneno (4,8\%). LIMBERGER e cols. (2001) empregando o óleo essencial de $C$. xanthocarpa, coletada no Rio Grande do Sul, determinaram como componentes principais o neridol $(28,8 \%)$ e o linalol $(17,2 \%)$. Verificam-se diferentes componentes nestas duas amostras. Outras determinaçães da composição do óleo seriam necessárias, em diferentes épocas de atividade da planta, para a comparação dos dados. 
$\mathrm{Na}$ análise cromatográfica em camada delgada do óleo essencial, o sistema que melhor evidenciou a mancha equivalente à substância química de referência - linalol - foi o constituido de sílica gel G, tolueno-acetato de etila (8:2), revelado com vanilina sulfúrica (tabelas 7 e 8). Esta substância foi eleita pela disponibilidade e presença na amostra utilizada neste estudo.

\subsection{ENSAIOS BIOLÓGICOS}

\subsubsection{Toxicidade aguda}

O ensaio de toxicidade aguda foi realizado como uma avaliação inicial dos possíveis efeitos tóxicos do extrato EHA de C. xanthocarpa. Na dose de $5 \mathrm{~g} / \mathrm{kg}$, por via oral, não apresentou toxicidade aguda. Logo após a administração do extrato observou-se alteração temporária de comportamento dos animais, evidenciados por tremores e baixo reflexo a estímulos mecânicos. Depois de 2 a 3 minutos mostraram sonolência. Decorridas 3 horas, verificou-se comportamento semelhante aos animais controle. As alterações foram menos intensas nas fêmeas. O aspecto macroscópico do fígado, rins, coração e pulmões, dos grupos controle e dos tratados foi semelhante, não apresentando alterações visíveis a olho nu.

As figuras 32 e 38 , que representam o consumo de água dos animais controle e tratados (fêmeas e machos, respectivamente) mostram que até 0 décimo primeiro dia o consumo foi maior nos grupos controle.

As figuras 33 e 39 , que representam o consumo de ração dos animais controle e tratados (fêmeas e machos, respectivamente), mostram que no grupo controle das fêmeas o consumo de ração foi maior até o nono dia. Nos animais machos não se verificou diferença de consumo pelo grupo controle e tratado, mas a tendência de aumento de consumo.

A análise estatística dos dados das tabelas 12 e 18, que representam a variação de massa corpórea dos animais controle e tratados (fêmeas e machos, 
respectivamente), apresentaram valores de $\rho>0,05$, sendo considerados não significativos, na comparação de massa corpórea dos grupos controle e tratados.

A avaliação estatística dos dados das tabelas $13,14,15,19,20$ e 21, que representam a massa relativa dos rins, fígados, e corações + pulmões, dos animais controle e tratados (fêmeas e machos, respectivamente), apresentaram valores de $p>0,05$ não significativos, mostrando que estatisticamente não houve diferenças entre os grupos controles e tratados, nos camundongos fêmeas e machos.

\subsubsection{Ensaio de letalidade de artêmias}

O ensaio de letalidade de artêmias tem sido utilizado como um bioensaio para uma variedade de substâncias tóxicas, e para o monitoramento de processos de isolamento de compostos bioativos em extratos vegetais (SOLIS, e cols., 1993, GUPTA e cols., 1996). Este ensaio é rápido, sensivel e de baixo custo.

O valor da dose letal do extrato EHA de C. xanthocarpa que mata $50 \%$ (DL50) das artêmias foi de $0,503 \mathrm{mg} / \mathrm{mL}$ (95\% de limite de confiança). MEYER (1982) registrou DL50 < $1000 \mathrm{\mu g} / \mathrm{mL}$ para oito extratos de euforbiáceas, conhecidas por conterem substâncias biologicamente ativas.

LACAILLE e cols. (1996) e SHASHI e cols. (1988) mostraram a ação citotóxica (in vitro), antitumoral (in vivo) e quimiopreventiva (in vitro e in vivo) de saponinas.

O extrato acetônico a $70 \%$ de Eugenia jambos apresentou potente atividade citotóxica sobre células leucêmicas humanas (YANG e cols., 2000). ZHENG e cols. (1992) detectaram atividade anticancerígena para os componentes do óleo essencial de Eugenia caryophyllata. SETZER e cols. (1999) verificaram atividade citotóxica sobre células Hep.G2 e células humanas cancerígenas SK-Mel-28, do óleo essencial dos frutos de Myrcianthes sp. Estas duas espécies pertencem à família Myrtaceae. 
O teor de saponinas e de taninos no extrato EHA foi de $16 \mathrm{~g} \%$ e de 8,5 g\%, respectivamente. Os resultados, em conjunto, são encorajadores para a identificação das frações ou dos componentes biologicamente ativos do extrato EHA de C. xanthocarpa.

\subsubsection{Atividade antimicrobiana}

A literatura reporta espécies pertencentes à família com atividade antimicrobiana: extratos de folhas de Eugenia caryophyllata (KUN e cols., 2000), de E. malaceensis (LOCHER e cols., 1995), de Psidium guajava (MOHAMED e cols., 1994; CÁCERES e cols., 1993: RABE e cols., 1997), entre outros (tabela 1).

Os ensaios de atividade antimicrobiana foram efetuados visando avaliar 0 uso de $C$. xanthocama, na medicina tradicional, para o tratamento de cistite e disenteria, citados por GEMTCHUINICOV (1976), CRAVO (1994) e ALICE e cols. (1996).

A atividade antimicrobiana de uma substância pode ser avaliada pelo seu valor de concentração mínima inibitória (CMI) em relação a um determinado microrganismo. O valor do CMI não representa um valor absoluto. O verdadeiro valor de CMI é aquele que está entre a mais baixa concentração que inibiu o crescimento do microrganismo (CMI lido) e a próxima concentração imediatamente inferior, sendo requisito necessário que as variáveis do método sejam monitoradas e controladas (ANDREWS, 2001).

Geralmente a reprodutibilidade do teste é obtida quando se trabalha em série de diluições dobradas. Quando a variabilidade da série de diluições é maior, o teste deve ser padronizado e cuidadosamente controlado, segundo THE NATIONAL COMMITEE FOR CLINICAL LABORATORY STANDARS (NCCLS, 2000).

FRANK e cols. (1950) comparam as técnicas de difusão em ágar e diluição em meio líquido. Numerosos antibióticos e diversas combinações de microrganismos foram testados. Os resultados foram similares para as duas 
técnicas (WHEAT, 2001). Para a determinação do CMI de C. xathocarpa, foi escolhido o método de diluição seriada em tubos. As desvantagens do método mencionadas são o tempo empregado na preparação e os recursos adicionais para a visualização do crescimento de microrganismos quando são analisadas amostras com substâncias particuladas. Entretanto, esse método é mais sensivel, preciso, por existir maior contato entre os microrganismos e o extrato analisado (GUNDIDZA, 1987). Esta técnica requer a amostra dispersa homogeneamente no meio de cultura. MITSCHER e cols (1987) na triagem de atividade antimicrobiana em mais de 1000 extratos de plantas superiores, usando o método de diluição, encontraram esta ação em $26 \%$ das plantas analisadas

No estudo de atividade antimicrobiana do extrato EHA, o parâmetro de avaliação do crescimento microbiano foi à turvação do meio. Os tubos que mostraram iribição de crescimento dos microrganismos, apresentaram precipitado, provavelmente devido à presença de taninos. $\mathrm{Na}$ subcultura realizada com estes precipitados observou-se crescimento microbiano. Os valores obtidos de CMI foram: $S$. aureus - < 1,0 e > 0,5 mg/mL; para $S$. cholerasius - $<0,5$ e $>0,1 \mathrm{mg} / \mathrm{mL}$ e para $C$. albicans - <1,0 e $>0,5 \mathrm{mg} / \mathrm{mL}$. Estes resultados são indicativos de ação biostática do extrato EHA em relação a S.aureus e S. cholerasius e C. albicans. Os microrganismos sofreram inibição de crescimento permanecendo viáveis. ZANI e CARMELINO (1994) não consideram atividade antimicrobiana de interesse para $C M I$ de valor superior a $0,1 \mathrm{mg} / \mathrm{mL}$ para substâncias puras. RIOS (1988) considera extratos vegetais com CMI < $1000 \mathrm{mg} / \mathrm{mL}$ com potencial para ensaios posteriores.

Atualmente diversas bactérias patogênicas tomaram-se resistentes a antibióticos de até terceira geração (cefalosporinas), e bem conhecidos são os efeitos adversos apresentados pelos mesmos.

Os metabólitos secundários de plantas superiores podem oferecer uma nova fonte de agentes antibacterianos (HALNEN, 1985, BRANTNER, e cols., 1994, BISIGNANO e cols., 2000). Saponinas triterpênicas, diterpenoides flavonóides e taninos tem sido relacionados à atividade antimicrobiana de várias 
plantas (BADER, 1987; SCALBERT, 1991, DIDRY e cols., 1999, ADENIYI e cols., 2000, HABIBI e cols., 2000). Uma das funções dos compostos polifenólicos nas plantas é a proteção contra a invasão de microrganismos. Grande número de flavonóides constitui uma classe de agentes antifúngicos, a luteolina representando um exemplo deste grupo com potente atividade (HARBORNE e cols, 2000).

BAUER (1976) e SCHMEDA-HIRSCHMANN e cols. (1995) isolaram e identificaram flavonóides entre os quais a miricetina em C. xanthocarpa. XU e cols. (2001) ensaiando vários flavonóides em relação a bactérias resistentes á vancomicina, verificou atividade antimicrobiana para a miricetina.

Saponinas são uma importante fonte de compostos antifúngicos (LACAILLE, e cols., 1996). Glicosídeos saponinícos de Solidago virgaurea e Bellis perennis inibiram o crescimento de leveduras patogênicas humanas (Candida sp) com intensidades diretamente relacionadas ao número de carbohidratos ligados à sapogenina (BADER e cols., 1987, BADER, 1994). A saponina isolada de Phytolacca octandra tem sido reportada por ser fungistática (MORENO, 1981).

Taninos são compostos polifenólicos com a propriedade de precipitar proteínas. A toxicidade de taninos para microrganismos é bem conhecida. Vários mecanismos podem estar envolvidos. O modo de ação depende do microrganismo (SCALBERT,1991). Este fato poderia explicar a grande diferença de valores de CMI para bactérias fungos e leveduras

Neste estudo não foram identificados os componentes das frações saponínica, flavonoídica e tânica do extrato EHA, mas a presença destas frações poderia estar associada à atividade biostática verificada.

\subsubsection{Atividade antiúlcera}

A úlcera péptica (gástrica ou duodenal) ocorre aproximadamente em 10\% da população, nos Estados Unidos. Alguns clínicos estimam que $50 \%$ de indivíduos saudáveis já sofreram de azia. A fisiopatologia da doença pode 
decorrer de um desequilíbrio entre os fatores agressores (ácido, pepsina, infecção por Helicobacter pyloni) e as defesas locais da mucosa (sécreção de bicarbonato, muco e prostaglandinas ) (BRUNTON, 1996).

As metas de terapia para o tratamento de úlceras são: aliviar a dor, promover a cicatrização e prevenir a reincidência.

As estratégias terapêuticas são direcionadas para manter o equilíbrio entre os fatores agressores e os fatores de defesa da mucosa gástrica. Assim, deve-se considerar a redução de exposição ácida ou a melhora da integridade da mucosa. Vários agentes terapêuticos, incluindo extratos vegetais, são empregados na inibição da secreção ácida ou para atuar nos mecanismos de defesa por aumento da produção de muco ou interferindo na sintese de prostaglandinas (AFIFI, 1997).

Diversos extratos vegetais mostraram atividade antiúlcera. "Rhinax" (um fitoterápico constituído de varias espécies vegetais) promoveu a citoproteção da mucosa gástrica em diversos modelos de ulceração em ratos (DHULEY, 1998). O extrato bruto de folhas de Casearia sylvestris apresentou atividade antiúlcera preventiva (BASILE e cols., 1990). A fração acetato de etila do extrato metanólico de frutos de Amomum subulatum promoveu efeito protetor na mucosa gástrica, no modelo de indução agudo por etanol (JAFRI e cols., 2001). NOAMESI e cols. (1994) estudaram as propriedades antiulcerativas de extratos aquosos de algumas plantas medicinais africanas. Extratos aquosos de Phoradendron crassifolium e Franseria artemisioides apresentaram atividade citoprotetora da mucosa gástrica comparável à atropina (Gonzáles e cols., 2000). A infusão de Lipia alba mostrou potente atividade antiúlcera, no ensaio de úlcera induzida por indometacina (PASCUAL e cols, 2001). O extrato aquoso de Anchusa strigosa apresentou atividade gastroprotetora no ensaio de indução de úlcera por etanol (ALMAD e cols., 1998).

Extratos fracionados de substâncias de origem vegetal tem sido avaliados quanto a esta atividade. A fração flavonoídica de Dittrichia viscosa mostrou efeito gastroprotetor as prostaglandinas endógenas não modulam a ação gastroprotetora dos flavonóides (DE LA LASTRA, 1993). Compostos como 
quercetina (HAVSTEEN, 1983; BEIL, 1995) e naringenina (MOTILVA, 1994) mostraram atividade citoprotetora. Polissacarideos da raiz de Bupleurum falcatum L. apresentaram atividade protetora e anti-secretora, em vários modelos experimentais de indução de úlcera (SUN e cols., 1991).

A atividade citoprotetora do extrato hidroalcoólico EHA de C. xanthocarpa foi avaliada utilizando-se ratos Wistar fêmeas. BACCHI (1988) observou que o sexo dos animais não influencia significativamente o resultado.

O modelo de indução de lesões ulcerativas pelo ácido clorídrico 0,3 $\mathrm{M}$ em etanol $60 \%$, permite avaliar a atividade de substâncias citoprotetoras. O etanol produz lesões necróticas na mucosa gástrica, reduzindo a secreção de bicarbonatos e produção de muco (MARAHUENDA e cols., 1993).

As substâncias citoprotetoras, são aquelas que aumentam a produção de muco e bicarbonato, através do estímulo das células parietais da mucosa estomacal, além de elevar a resistência das membranas celulares contra a agressão das altas concentrações de ácido clorídrico. As prostaglandinas (tipos $E, F$ e I), sintetizadas no trato gastrintestinal superior, atuam na secreção de muco e bicarbonato, regulação do fluxo sanguíneo e renovação celular (MILLER, 1983). Segundo TAKEUCHI e cols. (1985), o relaxamento do músculo do estômago, poderia ser uma proteção para a mucosa gástrica, através do achatamento das pregas. Este processo poderia diminuir a área exposta para agentes necrosantes e reduzir o volume de irritantes gástricos sobre as cristas rugosas.

O extrato (EHA) de C. xanthocarpa, na dose de $400 \mathrm{mg} / \mathrm{kg}$, por via oral, apresentou atividade citoprotetora, equivalente para dose de 0,100 mg/kg de misoprostol. Ambos apresentaram pouca efetividade para lesões moderadas (petéquias, no nivel I de ulceração). Fato concordante com ABOIN e cols. (1987) que administraram misoprostol anteriormente à exposição de ratos ao álcool absoluto. Observaram proteção da mucosa gástrica de lesões necróticas e hemorrágicas, porém não do dano leve da superfície da mucosa. Em relação às ulcerações severas e hemorrágicas o extrato EHA e o misoprostol mostraram 
equivalente atividade citoprotetora. O percentual de proteção do extrato EHA de C. xanthocarpa foi de $62 \%$ e do misoprostol de $64 \%$. O aspecto macroscópico dos estômagos dos animais tratados com o extrato EHA mostraram coloração mais clara, quando comparada com a dos animais tratados com misoprostol, assim como a preservação das vilosidades (Fig 44).

O presente estudo demonstrou a ação citoprotetora do extrato EHA, no modelo de indução aguda por ácido clorídrico em etanol, atividade atribuivel às classes de compostos detectadas no extrato. A literatura atribui atividade antiúlcera a compostos fenólicos (taninos e flavonóides) e saponinas (LAKSHMI e cols., 1976; RAO e cols., 1976, SAIRAN e cols., 2001, GEETHA e cols., 2002). Alguns desses compostos exercem atividade diretamente sobre as propriedades físico-químicas do muco e de seus constituintes.

A ação antioxidante atribuída aos flavonóides e taninos, tem sido relacionada à atividade antiúlcera, visto que os radicais livres desempenham papel importante nos processos ulcerativos e erosivos da mucosa.

A aplicação de agentes necrosantes como o etanol intensifica a lipoperoxidação, reduzindo o nível de compostos sulfidrílicos na mucosa gástrica, indicando que o oxigênio derivado de radicais livres e a peroxidação lipídica estão envolvidos como agentes necrosantes. Os flavonóides tem sido considerados como protótipos de atividade seqüestradora e supressora de radicais livres in vivo e in vitro, podendo interferir na produção de metabólitos do ácido araquidônico pela inibição direta da enzima lipoxigenase e reduzindo a concentração de leucotrinas (HODEK e cols, 2002).

Saponinas, taninos e flavonóides foram detectados no extrato EHA sendo possivel sugerir que esses componentes sejam pelo menos em parte, responsáveis pela atividade antiúlcera através da atividade antioxidante. 


\subsubsection{Atividade antioxidante}

A toxicidade apresentada, em animais de laboratório, por antioxidantes sintéticos tem contribuído para o crescente interesse na busca deste grupo de substâncias entre os vegetais.

$\mathrm{O}$ butil de hidroxianisol (BHA) e o butil de hidroxitolueno (BHT), amplamente empregados na indústria alimentícia, tem sido sugeridos como carcinogênicos e hepatotóxicos (GRICE e cols., 1986; CARLOTTI e cols., 1994, MYAKE, 1997).

As plantas mostraram-se uma fonte promissora de antioxidantes mais efetivos e menos tóxicos, possibilitando o uso na indústria de alimentos e na farmacêutica. É bem conhecido que dietas ricas com frutas e vegetais, são protetoras contra doenças cardiovasculares, certos tipos de câncer e outras doenças causadas por estresse oxidativo. Os efeitos protetores tem sido atribuídos a vitamina $C, \beta$-caroteno, flavonóides e fenilpropanóides (HERTOG, 1993). Um estudo epidemiológico realizado na Holanda, mostrou que as doenças coronarianas em homens mais idosos é inversamente proporcional à dieta rica em flavonóides. As maiores fontes de flavonóides na dieta provém do chá, cebola, maçãs, legumes e vinho tinto (RENAUD e cols., 1992).

A triagem fitoquímica de $C$. xanthocarpa revelou presença de flavonóides, taninos, saponinas e óleo essencial (Tabela 3). Com base nestes dados foi pesquisada a presença de substâncias com atividade antioxidante no extrato EHA, através de análise cromatográfica em camada delgada.

O sistema cromatográfico que apresentou uma boa resolução para estas substâncias foi o constituído de celulose como fase estacionária e a mistura de ácido acético glacial: água (3:7) como fase móvel. Duas manchas, de hRf 50 e 54 , apresentaram inibição da oxidação do $\beta$-caroteno, permanecendo a coloração alaranjada, por mais de 12 horas. A intensidade de coloração mostrou-se comparável à da quercetina (hRF 16), empregada como substância de referência. Estas substâncias não foram isoladas e identificadas, mas sugere-se 
que sejam flavonóides, pela fluorescência que apresentaram na luz ultravioleta e revelação com NP/PEG. Com o resultado indicativo da presença de substâncias antioxidantes no extrato, foi efetuada a avaliação da capacidade antioxidante em dois modelos, o da inibição da lipoperoxidação espontânea de cérebro de ratos e o da inibição da lipoperoxidação de lipoproteínas de baixa densidade (LDL) induzida por sulfato de cobre.

A medida da produção de malonildialdeído (MDA) foi avaliada através da reação entre este produto e o ácido tiobarbitúrico (TBARS). BARROS e cols. (1996) encontraram o valor de $Q_{1 / 2}$ (concentração necessária para atingir $50 \%$ da capacidade antioxidante) para $\alpha$-tocoferol na ordem de $12,1 \mu \mathrm{g} / \mathrm{mL}$. WADT (2000) determinou o valor de $Q_{1 / 2}$ de $53,06 \mu \mathrm{g} / \mathrm{mL}$ para Leonurus sibinicus e SILVA (2001), $Q_{1 / 2}$ de $0,51 \mu \mathrm{g} / \mathrm{mL}$ para o extrato de Myrciaria glomerata. extrato EHA de $C$. xanthocarpa apresentou $Q_{1 / 2}=0,29 \mu \mathrm{g} / \mathrm{mL}$ indicando capacidade antioxidante superior à do $\alpha$-tocoferol.

Os compostos fenólicos são agentes antioxidantes supressores "chainbreaking antioxidants", que fazem parte do sistema secundário de defesa contra radicais livres. São protótipos de agentes que atuam inibindo a fase de propagação da peroxidação lipídica, por sequestração dos radicais peroxila, $\mathrm{HO}^{-}$ assim como $\mathrm{O}_{2}^{-}$. Além disso, esses compostos apresentam grande afinidade por ferro, que é conhecido por catalisar processos que levam à formação de radicais livres. Sua capacidade antiperoxila poderia ser atribuida à capacidade de quelar ferro (SLOBODAN e cols, 1995).

A capacidade de seqüestrar radicais hidroxila, anion superóxido e peroxila lipídicos, previne doenças associadas a danos oxidativos a membranas, proteínas e DNA (FERGUSON,2001).

BARCLAY e cols. (1990) avaliaram a atividade de compostos fenólicos contra radicais livres resultantes da peroxidação de fosfolipideos das membranas. Demonstraram a necessidade de ser avaliada a capacidade antioxidante de compostos em modelos de sistemas de membranas assim como em solução para julgar a capacidade antioxidante em sistemas biológicos naturais. 
SAIJA e cols. (1994) estudaram o mecanismo básico da atividade antioxidante de 4 flavonóides (quercetina, hesperidina, naringenina e rutina) e a capacidade de interagir com biomembranas. Os modelos utilizados foram o da medida de produção de malonildialdeído (MDA) em homogenatos de cérebro de ratos e o da indução da peroxidação de linoleato com sais de $\mathrm{Fe}^{2+}$. Os resultados mostraram a atividade antioxidante dos flavonóides não só pelas características estruturais assim como pela localização na interfase lipídeos/água das membranas celulares.

O segundo modelo para avaliar a capacidade antioxidante do extrato EHA de C. xanthocarpa foi através da inibição da peroxidação lipídica de LDL, avaliando-se os efeitos do extrato na cinética da reação.

As lipoproteínas, transportadoras dos lípides na circulação sanguínea e linfática, são constituídas por uma parte central (core) contendo lípides apolares (trigliceróis e ésteres de colesterol) envolvida por uma camada superficial de lípides anfifilicos (colesterol não esterificado e fosfolipides) e proteinas (apolipoproteínas). A classificação dessas partículas em: lipoproteínas plasmáticas de densidade muito baixa (VLDL), de baixa densidade (LDL) e lipoproteinas de alta densidade (HDL), (ESTERBAUER e cols., 1992,), são passiveis de sofrerem modificaçōes oxidativas.

No estresse oxidativo, a oxidação dos ácidos graxos insaturados ocorre exponencialmente. Hoje é conhecido que a oxidação de LDL, tem um papel importante na patogênese da aterosclerose (ESTERBAUER, e cols., 1992, ABDALLA, 1995, CHANG, 1996, CADENAS e cols., 1997, IIZUKA e cols., 1998). No plasma sanguíneo as reações de peroxidação podem ser iniciadas por metais de transição, como cobre e ferro (HARMAN, 1986), pela oxidação de homocisteína, ou por espécies reativas de oxigênio geradas por neutrófilos, plaquetas e células de músculo liso (SARKS e cols., 1978).

As lipoproteinas oxidadas poderiam atuar em diversos niveis na aterogênese, ou seja, desde a transdução de sinal celular, que resultaria na produção de mediadores importantes para a fisiologia do endotélio e para o 
processo aterosclerótico até a formação das células espumosas (ABDALLA, 1995)

A aterosclerose é uma doença progressiva dos vasos sanguíneos caracterizada pelo depósito de lípides na camada intima das artérias. As alterações ateroscleróticas começam a se desenvolver em estágios iniciais da vida. A sintomatologia clínica da doença cardiovascular, como, o infarto do miocárdio, e o acidente vascular cerebral manifesta-se apenas na fase adulta (ROSS, 1986).

A indução da reação, no ensaio com o extrato EHA, foi através dos ions cobre (II) como agente oxidante. Quantidades catalíticas de ions cobre (II) oxidam a LDL. Os mecanismos pelos quais o cobre inicia a reação de peroxidação da LDL são incertos. Tem sido sugerido dois sítios de ligação do cobre com a LDL: o primeiro, ligado à apoproteína B100 e o segundo na vizinhança da fase lipídica (CADENAS, 1998). Segundo CHANG e cols. (1997), a lipoperoxidação de LDL, induzida por sais de cobre, é iniciada pela clássica seqüência: fase de iniciação, propagação e terminação da formação de radicais livres, envolvendo os ácidos graxos poliinsaturados.

A velocidade da indução do processo de peroxidação dos lipídeos da LDL (Lag-time ou Lag-phase), depende das quantidades de antioxidantes presentes. Correlações positivas foram observadas entre a concentração plasmática de $\alpha$ tocoferol e licopeno (KONTUSSH e cols., 1996). A fase de indução, na qual ocorre uma pequena oxidação, seguida por um aumento rápido na autocatálise por propagação em cadeia, é prolongada por antioxidantes que são supressores da reação por sequestração dos iniciadores da reação (CADENAS e cols., 1998).

Estudos de inibição da oxidação de LDL foram realizados com uma variedade de antioxidantes. ESTERBAUER (1992), verificou que $100 \mu \mathrm{mol}$ de vitamina $E$ por $\mathrm{mg}$ de proteína de LDL, inibiu a oxidação da LDL por 24 horas.

Os inibidores mais potentes da oxidação de LDL são compostos que complexam os ions cobre ou ions ferro; assim, o EDTA (ácido etileno diamino tetracético) é utilizado na proteção de LDL durante o seu isolamento. BHT e 
probucol são citados como potentes inibidores da oxidação de LDL (ESTERBAUER e cols., 1992).

Pouco tem sido realizado com produtos vegetais. LIZUKA e cols. (1998) estudando um fitoterápico constituído de 8 ervas, denominado "Daí-saiko-to", verificou aumento no tempo da fase de indução da oxidação da LDL, de modo significativo, apontando atividade antioxidante.

No grupo das substâncias químicas, diversos flavonóides e $\alpha$-tocoferol são mencionados como antioxidantes, supressores da cadeia de reação de radicais livres. Devido à grande afinidade por íons ferro inibem a peroxidação lipídica induzida por sais deste metal. Essa atividade dos compostos flavonoídicos e atocoferol foi comparável à do BHT e muitas vezes superior (BERGMAN e cols., 2001).

O extrato EHA de C. xanthocarpa mostrou aumento progressivo do tempo de iniciação da lipoperoxidação da LDL com concentrações progressivas do extrato de EHA até a concentração de $1,25 \mu \mathrm{g} / \mathrm{mL}$. A concentração de $2,5 \mu \mathrm{g} / \mathrm{mL}$ (curva 6) inibiu totalmente a lipoperoxidação da LDL até 200 minutos (tempo máximo utilizado para leitura, no experimento), não havendo formação de dienos conjugados (Fig. 36). Esta atividade antioxidante in vitro do extrato EHA na oxidabilidade da LDL pode estar associada aos compostos fenólicos detectados. 


\section{CONCLUSÕES}

Sob o aspecto farmacobotânico, as folhas de C. xanthocarpa proposta como droga vegetal, apresentou lâmina foliar oval-lanceolada, elíptica, castanhoesverdeada, ondulada nas bordas, subpapirácea a subcoriácea, 4 a 7 pares de nervuras secundárias, formando ângulos de $55^{\circ} \mathrm{em}$ média com a nervura mediana, curvando-se em direção ao ápice e urindo-se na nervura marginal, pontos translúcidos distribuídos na lâmina, pecíolos curvos e caniculados, odor aromático e sabor amargo. As características anatômicas observadas foram mesofilo dorsiventral, parênquima paliçádico com duas a três camadas de células, observando-se por vezes, idioblastos cristalíferos alcançando cerca de um terço da largura do mesofilo, parênquima lacunoso com cinco a sete camadas de células, delimitando espaços intercelulares de tamanhos variados, predominância de estômatos anomocíticos nas folhas hipoestomáticas, cavidades secretoras associadas às duas superfícies e recobertas por células aos pares, com a parede comissural reta, sinuosa ou em zig-zag, feixe vascular bicolateral, e sistema disposto em arco aberto, envolvido por bainha esclerenquimática descontínua, elementos xilemáticos dispostos radialmente, separados por raios constituídos de 1 a 2 fileiras de células e cristais prismáticos na regiãơ floemática.

$\mathrm{Na}$ droga vegetal e no extrato liofilizado (EHA) foram detectados flavonóides, taninos e saponinas. O teor de óleo essencial nas folhas frescas foi de $0,11 \%$, sendo identificados como maiores componentes o linalol $(29 \%) \mathrm{e}$ globulol (20\%). Mancha correspondente ao linalol foi detectada na análise cromatográfica em camada delgada do óleo volátil, evidenciado também na droga. O teor de taninos na droga foi de $2,86 \%$ e no extrato EHA de $8,49 \%$. O teor de saponinas na droga foi de $6,27 \%$ e no extrato EHA de $16 \%$.

O extrato EHA apresentou alta capacidade antioxidante no modelo de inibição de lipoperoxidação espontânea de cérebro de ratos, com $Q_{1 / 2}=0,2891$ $\mu \mathrm{g} / \mathrm{mL}$. No ensaio de inibição da lipoperoxidação, induzida por sulfato de cobre, da lipoproteína de baixa densidade (LDL), o extrato EHA diminuiu 
significativamente a oxidabilidade de LDL. O extrato EHA apresentou atividade antiúlcera no modelo de indução aguda por ácido clorídrico em etanol a 60\%, com percentual de proteção de $62 \%$. O extrato EHA apresentou atividade biostática com: CMI $>1.000$ e $<500 \mu \mathrm{g} / \mathrm{mL}$ em relação a Staphylococcus aureus; CMI $<500$ e $>100 \mu \mathrm{g} / \mathrm{mL}$ para Salmonella cholerasuis e CMI <1.000 e >500 $\mu \mathrm{g} / \mathrm{mL}$ em relação a Candida albicans. O extrato EHA mostrou atividade citotóxica no ensaio da letalidade de artêmias, com $\mathrm{DL}_{50}$ de $0,503 \mathrm{mg} / \mathrm{mL}$. $O$ extrato EHA não apresentou toxicidade no ensaio de toxicidade aguda, na dose de $5 \mathrm{~g} / \mathrm{kg}$ de peso do animal, por via oral. 


\section{RESUMO}

Campomanesia xanthocarpa Berg, espécie pertencente à familia Myrtaceae, é conhecida popularmente como gabiroba. Diversas propriedades terapêuticas são atribuídas às espécies de Campomanesia, tais como, combate à disenteria, febre, cistites e uretrites. O presente trabalho objetiva contribuir para elaboração de monografia da espécie, através do estudo químico e farmacológico do extrato hidroalcoólico liofilizado e da droga vegetal constituída de folhas. Os caracteres farmacobotânicos da droga vegetal são apresentados com o intuito de auxiliar a diagnose. Dentre as principais características macroscópicas das folhas desidratadas podem ser citadas: ondulação nas bordas; pontos translúcidos na lâmina, tipo de venação, forma da lâmina e dos pecíolos, e odor aromático. As características anatômicas que se destacaram são: mesofilo dorsiventral; grandes idioblastos contendo cristal prismático na região paliçádica; predominância de estômatos anomocíticos nas folhas hipoestomáticas; cavidades secretoras globosas, associadas a ambas as superfícies, recobertas por células dispostas aos pares em que a parede comissural mostra-se reta, sinuosa ou de "zig-zag"; feixe vascular bicolateral e sistema disposto em arco aberto; cristais prismáticos na região floemática. Fotomicrografias ilustraram o trabalho. A triagem fitoquimica da droga vegetal e do extrato liofilizado (EHA) indicou a presença de flavonóides, taninos, saponinas e óleo essencial. O teor de óleo essencial nas folhas frescas, foi de $0,11 \%$. Linalol $(29 \%)$ e globulol $(20 \%)$ foram identificados como os principais componentes do óleo. O teor de taninos na droga foi de $2,86 \%$ e no extrato EHA, de $8,49 \%$. O teor de saponinas na droga foi de $6,27 \%$ e no extrato EHA de $16 \%$. $O$ extrato apresentou elevada atividade antioxidante no modelo de medida de produção de malonildialdeído, com $Q_{12}=0,2891 \mu \mathrm{g} / \mathrm{mL}$. No ensaio da inibição da lipoperoxidação, induzida por sulfato de cobre, o extrato EHA reduziu significativamente o tempo de indução ("Lag-time") e o tempo de terminação ("Peak-time") da oxidabilidade de lipoproteínas de baixa densidade (LDL). O extrato EHA apresentou atividade antiúlcera no modelo de indução aguda por 
ácido clorídrico em etanol, com percentual de proteção de $62 \%$. O extrato EHA apresentou atividade antimicrobiana com: $\mathrm{CMI}>1.000$ e $<500 \mu \mathrm{g} / \mathrm{mL}$ em relação a Staphylococcus aureus; CMI $<500$ e $>100 \mu \mathrm{g} / \mathrm{mL}$ para Salmonella cholerasuis e CMI $<1.000$ e $>500 \mu \mathrm{g} / \mathrm{mL}$ em relação a Candida albicans. O extrato EHA mostrou atividade citotóxica no ensaio da letalidade de artêmias, com $\mathrm{DL}_{50}$ de $0,503 \mathrm{mg} / \mathrm{mL}$. O extrato EHA não apresentou toxicidade no ensaio de toxicidade aguda, na dose de $5 \mathrm{~g} / \mathrm{kg}$ de peso do animal, por via oral. 


\section{ABSTRACT}

Campomanesia xanthocarpa Berg, a species that belongs to the Myrtaceae family, is popularly known as gabiroba. Several therapeutic properties are attributed to the various Campomanesia species, such as treating diarrhea, fever, cystitis and urethritis. This project aims at contributing through a chemical and pharmacological study of lyophilized hydrated alcohol extract and the vegetable drug made from leaves. The pharmacological and botanical features of the vegetable drug are indicated in order to help with the diagnosis. Main macroscopic features of the dehydrated leaves include: wavy edges, translucent blade spots, venation type, blade and leafstalk forms and scent. The main anatomical features are: dorsiventral mesophyll; large idoblasts containing prismatic crystal in the palisade parenchyma; predominance of anomocytic stomata in the hypostomatic leaves, globose segregating cavity associated to both surfaces, covered by cells organized in pairs where the commissure wall appears straight, sinuous, or in zigzag; bicollateral vascular bundle and system organized in an open arch, prismatic crystals in the phloem region. Photomicographs illustrate the study. The phytochemical screening of the vegetable drug and the lyophilized extract (EHA) indicated the presence of essential oil, flavonoids, tannins and saponins. The essential oil content in the fresh leaves was $0.11 \%$. Linalol (29\%) and globulol (20\%) were identified as the main oil components. Tannin content was $2.86 \%$ in the drug and $8.49 \%$ in the EHA extract. The saponin content was $6.27 \%$ in the drug and $16 \%$ in the EHA extract. The extract displayed a high antioxidant activity in the model of malonyl dialdehyde production measure with $Q_{1 / 2}=0,2891 \mu \mathrm{g} / \mathrm{mL}$. In the copper sulfateinduced lipoperoxydation inhibition assay the EHA extract significantly reduced Lag-time and Peak-time for low-density lipoprotein (LDL) oxidability. The EHA extract displayed antiulceration activity in the acute induction model by hydrochloric acid in ethanol, with a $62 \%$ protection percentage. The EHA extract displayed antibacterial activity with: $\mathrm{CMI}>1,000$ and $<500 \mu \mathrm{g} / \mathrm{mL}$ relative to 
Staphylococcus aureus; CMI $<500$ and $>100 \mu \mathrm{g} / \mathrm{mL}$ for Salmonella cholerasuis and $\mathrm{CMI}<1.000$ and $>500 \mu \mathrm{g} / \mathrm{mL}$ regarding Candida albicans. The EHA extract displayed cytotoxic activity in the artemias lethality trial, with $D L_{50}$ of $0,503 \mathrm{mg} / \mathrm{mL}$. The EHA extract displayed no toxicity in the acute toxicity trial in the $5 \mathrm{~g} / \mathrm{kilo}$ oral dosage per animal body weight. 


\section{REFERÊNCIAS BIBLIOGRÁFICAS}

ABAUL, J., BOURGEOIS, P., BESSIERE, J.M. Chemical composition of the essential oils of chemotypes of Pimenta racemosa var. racemosa. (P. Miller). Flavor Fragr. J., Chishester, v.10, n.5, p.319-321, 1995.

ADEBAJO, A.C., OLEKE, K.J., ALADESANMI, A.J. Antimicrobial activities and microbial transformation of volátile oils of Eugenia uniflora. Fitoterapia, Milan, v. 60, n. 5, p. $451-455,1989$.

ABDALLA, D.S.P. Radicais livres e antioxidantes. In: OGA, S. Fundamentos deToxicologia. São Paulo: Atheneu, 1996. cap.1.4, p.37-58.

ABDALLA, D.S.P. Modificações oxidativas das lipoproteinas e suas implicações na aterogênese. São Paulo. 1995. 65p. (Tese de Livre Docência- Faculdade de Ciências Farmacêuticas- USP).

ABOIN, E., ARQUERO, P., BALBOA, V. Prostaglandina PGE, análogo sintético (misoprostol) no manuseio de lesões da mucosa gástrica induzidas pelo etanol. Arq. Brás. de Méd., Rio de Janeiro, v.61, p.277-283, 1987.

ACHENBACH, H., RAFFELSBERGER, B., BULLINGER, G. Constituenst of West African medicinal plants. 4 alkaloids in tabernaemontana species. 10-19hydroxycoronairidin and 19-hydroxybogarmines. Two antibiotics alkaloids of the bogamine type. Phytochemistry, Oxford, v.19, p.2185-2188, 1980.

ACHREKAR, S., KAKLIJ, G.S., POTE, M.S., KELKAR, S.M. Hipoglycemic activity of Eugenia jambolana and Ficus bengalensis: Mechanism of action. In Vivo, Kapandriti, v.5, n.2, p.143-148, 1991 
ADENIYI, B., FONG, H., PEZZUTO, J.M., LUYENGI, L., ODELOLA, H.A. Antibacterial activity of diospyrin, isodiospyrin and biisodiospyrin from the root of Dispyros piscatoria (Gurke). Phytother. Res., Bognor Regis, n.14, p.112$117,2000$.

AFIFI, F.U., KHALIL, E., TAMINI, S.O., DISI, A. Evaluation of gastroprotective effect of Laurus nobilis seeds on ethanol induced gastric ulcer in rats. J. Ethonopharmacol., Lausane, v.58, p.9-14, 1997.

AKHTAR, H.H.; AHMAD, K.V. Anti-ulcerogenic evaluation of the metanolic extracts of some indigenous medicinal plants of Pakistan in aspirin ulcered rats. J. Ethonopharmacol., Lausane, v.46, p.1-6, 1995.

AKIRA, T., TANAKA, S., TABATA, M. Pharmacological studies on the antiulcerogenic activity of Chinese cinnamon. Planta Med., Stuttgart, v.52, p.440-443, 1986.

ALARCON DE LA LASTRA, C., LÓPEZ, A., MOTILVA, V. Gastroprotection and Prostaglandin E2 Generation in rats by flavonoids of Dittrichia viscosa. Planta Med., Stuttgart, v.59, p.497-501, 1993.

ALICE, C.B., SIQUEIRA, N.C.S., MENTZ, LA., BRASIL E SILVA, G.A.A, JOSE, K.F.D. Plantas medicinais de uso popular:atlas Farmacognóstico. Canoas: ULBRA, 1995. p. 59-61.

ALKOFAHI, A., ATTA, A.H. Pharmacological screening of the anti-ulcerogenic effects of some Jordanian medicinal plants in rats. J. Ethnopharmacol., Lausane, v.67, p.341-345, 1999. 
ALMAD, M.D., SALAB, O.T., GHALEB, M.A. Effects of Anchusa strigosa root aqueous extract on gastric ethanol- induced ulcerin laboratory animals. J. Ethnopharmacol., Lausane, v.60, p.189-198, 1998.

ALMEIDA, C.E., KARNIKOWSKI, M.G.O., FOLETO, R., BALDISSEROTTO, B. Analysis of antidiarrhoeic effect of plants used in popular medicine. Rev. Saúde Pública, São Paulo, v.29, n.6, p.428-433, 1995.

AL-ZAID, M.M., HASSAN, M.A.M., BADIR, N., GUMAA, K.A. Evaluation of blood glucose lowering activity of three plant diet additives. Int. J. Pharmacogn., Lisse, v.29, n.2, p.81-88, 1991.

ANDRADE, J.D.S., ARAGÃO, C.G., FERREIRA, S.A.D.N. Physical and chemical characteristics of Araça-pera (Psidium acutangulum D.C.) fruits. Acta Amazonica, Manaus, v.23, n.2/3, p.213-217, 1993.

ANDREWS, J.M. Determination of minimum inhibitory concentrations. J. Antimicrob. Chemother., Oxford, v.48, n.1, p.5-16, 2001.

ANESINI, C., PEREZ, C. Screening of plants used in Argentine folk medicine for antimicrobial activity. J. Ethnopharmacol., Lausane, v.39, n.2, p.119-128, 1993

ARIYPSHI, I., TOSHIHARU, A., SUZIMURA, F., ABE, M., MATSUO, Y., HONDA, $T$. Recurrence during maintenence therapy with histamine $\mathrm{H}_{2}$ receptors antagonist in cases of gastric ulcers. Nihon Univ. J. Med., Tokyo, v.28, p.6974,1986

ARORA, A., NAIR, M.G. STRASBURG, G,M. Structure-activity relationships antioxidant activities of a series of flavonoids in a liposomal system. Free Radical Biol. Med., New York, v.24, p.135-136, 1998. 
AtTAguile, G., CARUSO, A., PENÍRISI, G., SAVOCA, F. Gastroprotective effects of aqueous extracts of Citus incanus in rats. Pharmacol. Res., London, v.31, p.29-32, 1995.

BACCHI, E.M. Estudo farmacológico da ação antiúlcera dos extratos de Styrax camporum Pohl e Caesalpina férrea Martius. São Paulo, 1988. 254p. (Tese de Doutorado-Instituto de Ciências Biomédicas - USP).

BACCHI, E.M., SERTIE, J. a , VILLA, N., KATZ, H. Antiulcer action and toxicity of Styyrax comporum and Caesalpinia férrea. Planta Med., Stuttgart, v.61, p.204-207, 1995.

BADER, G. Pharmakologische und biophamazeutische Bewertung von Triterpensaponinen. Pharmazie, Eschborn, v.49, p.391-400, 1994.

BADER, G., BINDER, K., HILLER, K., ZIEGLER-BOHME, H. The antifungal action of triterpene saponins of Solidago virgaurea L. Pharmazie, Eschborn, v. 42, p.140, 1987.

BALANEHRU, S., NAGARAJAN, B. Intervention of adriamycin induced free radical damage. Biochem. Int., Sydney, v.28, n.4, p.735-744, 1992.

BARCLAY, C.R.L., BASKIN, A.K., DAKIN, A.K., LOCKE, J.S., VINQVIST, R.M. The antioxidant activities of phenolic antioxidants in free radical peroxidation of phospholipid membranes. Can. J. Chem., Ottawa, v.68, p.2258-2269,1990.

BARROS, S.B.M., TEIXEIRA, D.S., AZNAR, A.E., MOREIRA JR., J.A., ISHII, I., FREITAS, P.C.D. Antioxidant activity of ethanolic extracts of Pothomorphe umbellata L. Miq. (Pariparoba). Free Radical Res., Amsterdam, v.48, n.1/2, p.114-116, 1996. 
BARROSO, G.M. Sistemática de angiospermas do Brasil. Rio de Janeiro: LTC; São Paulo: EDUSP, 1978. v.1, 255 p.

BARROSO, G.M., PEIXOTO, A.L. Sistemática de Angiospermas do Brasil. Viçosa: Universidade Federal de Viçosa, 1991. V.2, p. 114-126.

BARROSO, G.M., PERON, V. Myrtaceae, In: LIMA, M.P.M., eds. Reserva Ecológica de Macae de Cuna, Nova friburgo. R.J. aspectos florísticos das espécies vasculares, Rio de Janeiro: S.R. Guedes Brine, 1994. v.1, p.261-302.

BASILE, A.C., SERTIÉ, J.A.A., PANIZZA, S., OSHIRO, T.T. Pharmacological assay of Casearia silvestris I. Preventive anti-ulcer activity and toxicity of the leaf crude extract. J. Ethnopharmacol., Lausane, v.30, p.185-197, 1990.

BAUER, L. Flavonóides em folhas de Campomanesia xanthocarpa Berg. Myrtaceae. Porto Alegre, 1975. 20f. (Dissertação de Mestrado -Faculdade de Farmácia- UFRGS).

BEIL, W., BIRKHOLZ, C., SEWING, K.F.R. Effects of Flavonoids on Parietal Cell Acid Secretion, Gastric Mucosal Prostaglandin Production and Helicobacter pylori Growth. Arzneim-Forsch., Aulendorf, v.46, n.6, p.697-700, 1995.

BERG, O.K. Myrtaceae. In: Martius, K.P.Von., EICHIER, A.G., URBAN, I. Flora Brasiliensis, Monachii, Lipsiae, v.14, n.1, p.1-655, 1957.

BERGMAN, M., VARSHAVSKY, L., GOTTLIEB, E.H. The antioxidant activity of aqueous spinach extract: chemical identification of active fractions. Phytochemistry, Oxford, v.58, p.143-152, 2001. 
BISIGNANO, G., SANOGO, R., MARINO, A., AQUINO, R., D'ANGELO, V., GERMANO, M.P., DE-PASQUALE, R., PIZZA, C. Antimicrobial activity of Mitracarpus scaber extract and isolated constituents. Lett. Appl. Microbiol., Oxford, v.30, n.2, p.105-108, 2000.

BOURGEOIS, J.A., BESSIERE, P. Chemical composition of the essential oil of chemotypes of Pimenta racemosa var. racemosa (P. Miller). Flavour Frag. J., Chichester, v.10, n.5, p.319-321, 1995.

BRANTNER, A., GREM, E., Antibacterial activity of plant extracts used extemally in tradicional medicine. J. Ethnopharmacol., Lausane, v.44, p.35-40, 1994.

BRITO, A.C. Manual de ensaios toxicológicos in vivo. Campinas: Unicamp, 1994. p.15-22.

BROWN, H.A., MINOTT, D.A., INGRAM, C.W., WILLIAMS, L.A.D. Biological activities of the extracts and constituents of pimento, Pimenta dioica $L$ against the southem cattle tick, Boophilus microplus. Insect-Sci. Its Appl., Nairobi, v. 18, n.1, p.9-16, 1998.

BRUNE, K., BICKEL, D. PESKAR, B.A. Gastroprotective effects by extracts of Petasites hybridus: The role of inhibition of peptido-leukotriene synthesis. Planta Med., Stuttgart, v.59, p.494-496, 1993.

BRUNTON, L.L. Agents for control of gastric acidity and treatment of peptic ulcers. In: HARDMAN, J.G., LIMBIRD, L.E., MOLINOFF, P.B., RUDDON, R.W., GILMAN, A.G., eds. Goodman \& Gilman's the pharmacological basis of therapeutics. 9.ed. New York: MacGraw-Hill, 1996. cap.37, p.901915 . 
CACERES, A., Fletes, L., AGUILAR, L., RAMIREZ, O., FIGUERO, A.L., TARACENA, A.M., SAMAYOA, B. Plants used in Guatemala for the treatment of gastrointestinal disorders: 3 confirmation of activity against enterobacteria of 16 plants. J. Ethnopharmacol., Lausane, v.38, n.1, p.31-38, 1993.

CADENAS, E., SIES, H. The Lag Phase. Free. Rad. Res., Amsterdam, v.28, p.601-609, 1997.

CARLOTTI, M.E., GALLARATE, M., GASCO, R.M., TROTTA, M. Inhibition of lipoperoxidation of linoleic acid by five antioxidants of different lipophicity. Pharmazie, Frankfurt, v. 49, p.52-54, 1994.

CARRARA, N.R. Espécies de Campomanesia Ruiz \& Pavon (Myrtinae, Myrtaceae) ocorrentes no Estado do Rio de Janeiro. Rio de janeiro, 1997. 222p. (Dissertação de Mestrado-Museu Nacional-Universidade Federal do Rio de Janeiro).

CARVALHO, A.D.F.U., MELO, V.M.M., AGUIAR, L.M.B.A, MATOS, F.J.D.A. Toxicity evaluation of medicinal plant extracts by brine shrimp bioassay. Cienc. Cult., São Paulo, v.40, n.11, p.1109-1111, 1988.

CASTRO, O., GUTIERREZ, J.M., BARRIOS, M., CASTRO, I., ROMERO, M., UMANA, E. Neutralization of the haemorrhagic effect induced by Bothrop asper (Serpentes: Viperidae). Rev. Biol. Trop., São Jose, v.47, n.3, p.605616, 1999.

CATALANO, S., FLAMINI, G., BILIA, A.R., MORELLI, I, NICOLETTI, M. Iridoids from Mentzdra cordifolia. Phytochemistry, Oxford, v.38, p.895-897, 1995. 
CHANG, Y.H., ABDALLA, D.S.P., SEVANIAN, A. Characterization of cholesterol oxidation of products formed by oxidative modidfication of low density lipoprotein. Free Radical Biol. Med., New York, v.23, n.2, p.202-214, 1997.

CORDELL, G.A. Introduction to Alkaloides: a biogenetic approach. New York Wiley Interscience, 1981.

CORDELL, G.A. Pharmacognosy: new roots for an old science. In:_Study in Natural Products Chemistry, Elsevier Science Publishers B.V., v.13, p.623675, 1993.

CORDELL, G.A. Changing strategies in natural products chemistry. Phytochemistry, Oxford, v.40, n.6, p.1585-1612, 1995.

CORDELL, G.A. Biodiversity and drug discovery- a symbiotic relationship. Phytochemistry, Oxford, v.55, p.463-480, 2000

CORREA, M.P. Dicionário das plantas úteis do Brasil e das exóticas cultivadas. Rio de Janeiro: Imprensa Nacional, 1974. v. 5, p.512.

CORREA, M.P. Dicionário das plantas úteis do Brasil e das exóticas cultivadas. Rio de Janeiro: Nacional, 1952. v.3, p.429-432.

CORTADI, A., DI-SAPIO, O., GATTUSO, M. Anatomic characters of three medicinal species of the family Myrtaceae. Acta Farm. Bonaerense, La Plata, v.15, n.2, p.109-123, 1996.

COSTA, A.F. Farmacognosia, 2ed. Lisboa: Fundação Calouste Gulbenkian, 1978 , v.2, p.31-280. 
COSTA, T.R., FERNANDES, O.F.L., SANTOS, S., OLIVEIRA, C.M.A., LIAO, L.M., FERRI, P.H., PAULA, J.R., FERREIRA, H.D., SALES, B.H.N., SILVA, M.D.O.R. Antifungal activity of volatile constituents of Eugenia dysentenica leaf oil. J. Ethnopharmacol., Lausane, v.72, n.1-2, p.11-117, 2000.

CRAGG, G.M., NEWMAN, D.J., SNADER, K.M. Natural products in drug discovery and development. J. Nat. Prod., Columbus, v.60, n.1, p.52-60, 1997.

CRAVO, A.B. Frutas e ervas que curam: panacéia vegetal. 4.ed. São Paulo: Hemus, 1994. $438 p$.

CRONQUIST, A. The evolution and classification of flowering plants. New York: Botanical Garden, 1988, p.376-381.

CRONQUIST, A. The evolution and classification of flowering plants. New York: Columbia University Press, 1981, p. 287-340.

CRONQUIST, A. A commentary of the definition of order Myrtales. . Ann Missouri Bot. Gard, v.71, p.780-782, 1984.

CRONQUIST, A. A integrated system of classification of flowering plants. New York: Columbia University Press, 1996.

DA-SILVA, M.L., LUZ, A.T.R., ZOGHBI, M.G.B., RAMOS, L.,S., MAIA, J.G.S. Essential oil variation in Calyptranthes spruceana. Phytochemistry, Oxford, v.23, n.11, p.2515-2516, 1984.

DE PASQUALE, R., GERMANO, M.P., KIETA, A., SANOGO, R., LANK, L. Antiulcer activity of Pteleopsis suberosa. J. Ethonopharmacol., Lausane, v.47, p.29-32, 1995. 
DE SILVA, S.S.M., GAMAGE, S.K.T., KUMAR, N.S. Antibacterial activity of extracts from the brown seaweed Stoeschospermun marginatum. Phytochemistry, Oxford, v.21, p.944-945, 1982.

DHULEY, J.N., NAIK, S.R. Protection by rhinax® in various models of ulceration in rats. J. Ethonopharmacol., Lausane, v.63, p.219-225, 1998.

DIDRY, N., SEIDEL, V., DUBRENIL, L., TILLEQUIN, F., BAILLEUL, F. Isolation and antibacterial activity of phenylpropanoid derivates from Ballota nigra. J. Ethnopharmacol., Lausane, v.67, p.197-202, 1999.

DUGAS JUNIOR, A.J., CASTANHEDA, A., COSTA, J., BONIN, G., PRICE, K.L., FISCHER, N.H., WINSTON, G.W. Evaluation of total peroxil radical scavening capacity of flavonoids; structure-activity relationships. J. Nat. Prod., New York, v. 63, p. $327-331,2000$

EKUNDAYO, O., AJANI, F., SEPPANEN, L.T., LAAKSO, I. Volatile constituents of Psidium guajava $L$ (guava) fruits. Flavour Fragr.J.,Chichester, v.6, n.3, p.233-236, 1991.

EL-BULK, R.E., BABIKER, E.F.E., EL-TINAY, A.H. Changes in chemical composition of guava fruits during development and ripening. Food Chem., Oxford, v.59, n.3, p.395-399, 1997.

ELFELLAH, M.S., AKHTER, M.H., KHAN, M.T. Anti-hyperglycemic effect of an extract of Myrtus communis in streptogotocin-induced diabetes in mice. J. Ethnopharmacol, Lausane, v.11, p.275-282, 1984. 
ESTERBALER, H., GEBCKI, J., PUHL, H., JURGENS, G. The role of lipid peroxidation and antioxidants in oxidative modification of LDL. Free Radical Biol. Med., New York, v.13, p.341-190, 1992.

EUROPEAN Pharmacopeia, 3.ed. Sainte- Ruffine: Maisonneuve, 2001, p.105.

FARMACOPÉIA Brasileira. 4.ed. São Paulo: Atheneu, 1988. V.2, p.11-12.

FARNSWORTH, N. R., AKERLE, O. BURGEL,A.S., SOEJARTO, D.D., GUO, Z. Medicinal Plants in Therapy Bull. W. H. O., Geneva, v.63, n.3, p.965, 1985.

FARNSWORTH, N.R. Biological and phytochemical screening of plants. J. Pharm. Sci., New York, v.55, n.3, p.225-263, 1966.

FERGUSON, L.R. Role of plant polyphenols in genomic stability. Mutat Res., v.475, p.89-111, 2001.

FERNANDEZ, M.L., RAMACHANDRAN, N.A.G., ALCARAZ, M.J. Inhibition of sheep platelet arachidonate metabolism by flavonoids from Spanish and Indian medicinal hertss. Pharmazie, Eschbom, v.45, p.205-208, 1990.

FERNANDEZ, M.A., GARCIA, M.D., SÁENZ, M.T. Antibacterial activity of the phenolic acids fractions of Scrophularia frutensces and Scrophularia sambucifolia. J. Ethnopharmacol., Lausane, v.53, p.11-14, 1996

FERRI, M.G. Informações sobre a transpiração e anatomia foliar de diversas mirtáceas. Ciênc. Cult., São Paulo, v.23, n.3, p.313-316, 1971.

FINNEY, D. J. Probit analysis. 3.ed. Cambridge: Cambridge University Press, 1971. p.333. 
FONTENELle, G.B., COSTA, C.G., MACHADO, R.D. Foliar anatomy and micromorphology of eleven species of Eugenia (Myrtaceae). Bot. J. Linn. Soc., London, v.115, p.11-133, 1994.

FRANCO, M.R.B., SHIBAMOTO,T. Volatile composition of some Brazilian fruits: Umbu-caja (Spondias citherea), camu-camu (Myrciaria dubia), araça-boi (Eugenia stipitata), and cupuacu (Theobroma grandiflorum). J. Agric. FoodChem., Columbus, v.48, n.4, p.1263-1265, 2000.

FRANKLIN, G.L. Preparation of thin sections of synthetic resins and wood-resin composites, and a new macerating method for wood. Nature, London, v.155, n. 3924, p.51, 1945.

GEETHA, S., SAI RAM, M., SINGH, V., LLAVAZHAGAU, G., SAWHNEY, R.C. Antioxidant and immunomodulatory properties of seabuckthom (Hippohae rhamnoides) an in vitro study. J. Ethnopharmacol., Lausane, v.79, p.373-378, 2002.

GEMTCHÚJNICOV, I.D. Manual de Taxonomia Vegetal: plantas de interesse econômico, agrícola, ornamentais e medicinais. São Paulo: Agronômica Ceres, 1976. p.504-505.

GONZALES, E., IGLESIAS, I., CARRETERO, E., VILLAR, A. Gastric cytoprotection of Bolivian medicinal plants. J. Ethnopharmacol., Lausane, v.70, p.329-333, 2000.

GONZALES, F.G., PORTELA, T.Y., STIPP, E.J., DISTASE, L.C. Antiulcerogenic and analgesic effects of Maytenus aquifolium, Soroceae bomplandi and Zolernia ilicifolia. J. Ethnopharmacol., Lausane, v.77, p.41-47, 2001. 
GUARALDO, L., SERTIE, J.A.A., BACCHI, E.M. Antiulcer action of the hydroalcoholic extract and fractions of Davilla rugosa Poiret in the rat. J. Ethnopharmacol., Lausane, v.76, p.191-195, 2001.

GUERIN, J.C., REVEILLERE, H.P. Antifungal activity of plant extracts used in therapy. 2. Study of 40 plant extracs against 9 fungi species. Ann. Pharm. Fr., Paris, v.43, n.1, p.77-81, 1985.

GUNDIDZA, M. Antimicrobial activities of Helinus integrifolius. Fitoterapia, Milan, v. 43, n. 3, p. $180-183,1987$.

GUPTA, J.P., RAI, Y., DEBMEATER, P.K., SANYAH, A.K. A comparative study on the gastric secretion of histamine and pentagastrin on same Indian subjects Asian Med. J., Tokyo, v.23, p.553-565, 1980.

GUPTA, M.P., MONGE, A., KARIKAS, G.A., LOPEZ DE CERAIN, A., SOLIS, P.N., DE LEON, E., TRUJILLO, M., SUAREZ, O., WILSON, F., MONTENEGRO, G., NORIEGA, Y., SANTANA, A.I., CORREA, M., SANCHES, C. Screening of Panamanian medicinal plants for brine shrimp toxicity, crow call tumor inhibition, cytotoxicity and DNA intercalation. Int. J. Pharmacogn., Lisse, v.34, n.1, p.19-27, 1996.

HABIBI, Z., EFTEKHAN, F., SANIEE, K., RUSTAIYAN, A. Structure and antibacterial activity of 6 new labdane diterpenoid from Salvia leniaefolia. J. Nat. Prod., Columbus, v.63, p.270-271, 2000.

HAENEN, J.M. Phytoalexins: antibiotics substances from higer plants. Pharm. Int., v.6, p.194-196, 1985. 
HAGERMAN, A.E., BUTLER, L.G. Protein precipitation method for the quantitative determination of tannins. J. Agric. Food Chem., Columbus, v. 26, n. 4, p.809-812, 1978.

HARBORNE, J.B., WILLIAMS, A.C. Advances in flavonoids research since Phytochemistry, Oxford, v. 55, p.481-504, 2000.

HARMAN, D. Free radical theory of aging: role of free radicals in the orientation and evolution of life, aging and disease process In: Free radicals, aging and degenerative diseases. New York: Alan R, Liss, 1986. p.3-40.

HAVSTEEN, B., Flavonoids: a class of natural products of high pharmacological potency. Biochem. Pharmacol., New York, v.32, n.7, p.1141-1148, 1983.

HERTOG, M.G.L., FISKENS, E.J.M., HOLLMAN, P.C.H., KATAN, M.B, KROMHOUT, D. Dietary antioxidant flavonoids and risk of cornary heart disease: the Zutphen elderly study. Lancet, London, v.342, p.1007-1011, 1993.

HIRANO, M., KIYOHARA, H., MATSUMOTO, T., YAMADA, H.S. Structural studies of endopolygalacturonase-resistant fragments of an antiulcer pectin from the roots of Bupleurum falcatum L. Carbohydr. Res., Oxford, v.251, p.145-162, 1994.

HODEK, P., TREFIL, P., STIBOROVÁ, M. Flavonoids-potent and versatile biologically active compounds interacting with cytochromes P450. Chem.Biol. Interact., Shannon, v.139, p.1-21, 2002.

HUSSIN, K.H., CUTLER, D.F., MOORE, D.M. Leaf anatomical studies of Eugenia $L$ (Myrtaceae), studies from the Malay Península. Bot. J. Linn. Soc., London, v.113, p.137-155, 1992. 
IIZUKA, A., IIJIMA, T.O., YOSHIE, F., MAKINO, B., AMAGAYA, S., KOMATSU, K.K., MATSUMOTO, A., ITAKURA, H. Inhibitory effects of Dai-saiko-to (DaiChai-Hu-Tang) on the progression of atherosclerotic lesions in Kurosawa and Kusanagi-hypercholesterolemic rabbits. J. Ethnopharmacol., Lausane, v.63, p.209-218, 1998.

JAFRI, M.A., FARAH, KALIM, J., SINGH, S. Evaluation of the gastric antiulcerogenic effect of large cardamom (fruits of Amomum subulatum Roxb).

J. Ethonopharmacol., Lausane, v.75, p.89-94, 2001.

JAIN, P., KHANNA, N.K., TREHAN, N., PENDSE, V.K., GODHWANI, J.L. Antiinflamatory effects of an Ayurvedic preparation, Brahmi Rasayana, in rodents. Indian J. Exp. Biol., New Delhi, v.32, n.9, p.633-636, 1994.

JOHANSEN, D.A. Plant microtechnique. Oxford: MacGraw Hill. 1940. 523p. (Série McGraw-Hill publications in the botanical sciences).

JOLY, A.B. Botânica: introdução à taxonomia vegetal. 8.ed. São Paulo: Nacional, 1987. p.410-417. (Biblioteca Universitária, Série 3, Ciências Puras, v.4).

JOLY, A.B. Botânica: introdução à taxonomia vegetal. 10 ed. São Paulo: Nacional, 1991. p.504-505.

JORJE, L.I.F. Caracterização farmacobotânica e microscopia alimentar de seis espécies brasileiras de Myrtaceae Jussieu. São Paulo, 1992. (Dissertação de Mestrado -Faculdade de Ciências Farmacêuticas-USP).

KAUSEL, E. A contribuição al estúdio de las Mirtáceas chilenas. Rev. Argent. Agron., Buenos Aires, v.9, p.39-65, 1942. 
KAWASAKI, M.L. Flora da Serra do Cipó, Minas Gerais: Myrtaceae. Bol. Bot. Univ. São Paulo, São Paulo, v.11, p.121-170, 1989.

KAWASAKI, M.L., HOLST,B.K. New species and a new combination in Myrtaceae from northeastem South America. Britonia, Eilao, v.46, n.2, p.137-142, 1994.

KAWASAKI, M.L. A new species of Campomanesia (Myrtaceae) from southeastern Brasil. Britonia, Eilao, v.52, n.2, p.188-190, 2000.

KHATIJAH, H.H. Leaf anatomical studies of Eugenia $L$ (Myrtaceae) species from the Malay Península. Bot. J. Linn. Soc., London, v.110, p.137-156, 1992.

KIM, H.J., WOO, E.R., KIN, M.K., YANG, B.S., YU, Y.G., PARK, H., LEE, Y.S. Isolation of virus-cell fusion inhibitory components from Eugenia caryophyllata. Planta Med., Stuttgart, v.67, n.3, p.277-279, 2001.

KONTUSSH, A.; HUBNER, C.; FINCKER, B.; KOHLSCHUTTER, A.; BEISIEGEL, $\checkmark$. How different constituents of low density lipoprotein determine its oxidizability by cooper: a correlational approach. Free Radical Res., Amsterdam, v.24, p.135-137, 1996.

KOROLKOVAS, A., BURCKHALTER, J.H. Química Farmacêutica. Rio de Janeiro: Guanabara, 1988, p.47.

KRAUS, J.E., ARDIUM, M. Manual básico de métodos em morfologia vegetal. Rio de Janeiro: EDUR, 1989, 198p.

KUBOTA, K.Y., OHARA, M.T. Determinação do valor da concentração minima inibitória de drogas e extratos vegetais pelo método da diluição em meio líquido, utilizando microplacas. In: SIMPÓSIO DE INICIAÇÃO CIENTÍFICA DA 
UNIVERSIDADE DE SÃO PAULO, 6. Ribeirão Preto, 1998. Resumos. Ribeirão Preto: USP, 1998. p.119.

LACAILLE, D.M.A., WAGNER, H. A review of the biological and pharmacological activities of saponins. Phytomedicin, Jena, v.2, n.4, p.363-386, 1996.

LAKSHMI, V., CHAUHAN, J.S. Chemical examination of seeds of Amomum subulatum. J. Indian Chem. Soc., Calcutta, v.53, p.633, 1976.

LANDRUM, L.R. Campomanesia, Blepharocalyx, Legrandia, Acca, Myrrhinium and Luma (Myrtaceae). FI. Neotropica, v. 45, p.1-178, 1986.

LANDRUM, L.R. A new species of Campomanesia (Myrtaceae) from Brasil. Britonia, Eilao, v.39, n.2, p.245-247, 1987.

LANDRUM, L.R., KAWASAKI, M.L. The genera of Myrtaceae in Brasil: an illustrated synoptic treatment and identification keys. Britonia, Eilao, v.49, n.4, p.508-536, 1997.

LARSON, R.A. The antioxidants of higer plants. Phytochemistry, Oxford, v.27, n.4, p.969-978, 1988.

LEE, M.H., NISHIMOTO, S., YANG, L.L., YEN, K.Y., HATANO, T., HOSHIDA, T., OKUDA, T. Two macrocyclic hydrolysable tannin dimers from Eugenia uniflora. Phytochemistry, Oxford, v.44, n.7, p.1343-1349, 1997.

LEGRAND, C.D. Myrtaceae catharinese novae. Sellowiana, v.8, p.71-79, 1957

LEGRAND, C.D. Myrtaceae del Estado de Santa Catarina. Sellowiana, v.13, p.265-363, 1961 
LEGRAND, C.D., MATTOS, J.R. Novidades Taxonômicas em Myrtaceae. Loefgrenia, Porto Alegre, v.67, p.1-32, 1975.

LEGRAND, C.D., KLEIN, R.M. Mirtáceas: Campomanesia, Feijoa, Britoa, Myrrhinium, Hexachlamys, Siphoneugena, Myrciantes, Neomitranthes, Psidium. In: REITZ, P.R. FLora llustrada. Catarinense, Itajaí: Herbário Barbosa Rodrigues, p.573-730, 1977.

LEWIS, D.A., HANSON, D. Anti-ulcer drugs of plant origin. Progr. Med. Chem., Amsterdam, v.28, p.208-210, 1991.

LEWIS, E. Should we be concerned about herbal remedies. J. Ethnopharmacol., Lausane, v.47, p.141-164, 2001.

LIMA, E.O. , GOMPERTZ, O.F., GIESBRECHT, A.M., PAULO, M.Q. "In vitro" antifungal activity of oils obtainet from officinal plants against dermatophytes. Mycoses, v.36, n.9/10, p.333-336, 1993.

LIMBERGER, R.P., APEL, M.A ., SOBRAL, M., MORENO, P.R.H., HENRIQUES, A.T., MENUT, C. Aromatic plants from Brasil. XI. Chemical composition of essential oils from some Campomanesia species (Myrtaceae). J. Essent. Oil Res., Carol Stream, v.13, n.2, p.113-115, 2001.

LOCHER, C.P., BURCH, M.T., MOWER, H.F., BERESTECKY, J., DAVIS, H., VAN-POEL, B., LASURE, A., VANDEN-BERGHE, D.A., VLIETINCK, A.J. Antimicrobial activity and anti-complement activity of extracts obtained from selected Hawaiin medicinal plants. J. Ethnopharmacol., Lausane, v.49, n.1, p.23-32, 1995. 
LOWRY, O.H., ROSEBROUGHT, N.J., FARR, A.L., RANDALL, R.J. Protein measurement With the Folin reagent. J. Biol. Chem., Bethesda, v.193, p.265$269,1951$.

LUTTERODT, G.D. Inhibition of microlax-induced experimental diarrhoea with narcotic-like extracts of Psidium guajava leaf in rats. J. Ethnopharmacol., Lausane, v.37,n.2, p.151-157, 1992.

LUTTERODT, G.D., MALEQUE, A. Effects on mice locomotor activity of a narcotic-like principle from Psidium guajava leaves. J. Ethonopharmacol., Lausane, v.24, n.2/3, p.219-232, 1988.

MAHMOUD, I., ALKOFAHI, A., ABDELAZIZ, A. Mutagenic and toxic activities of several spices and some Jordanian medicinal plants. Int. J. Pharmacogn., Lisse, v.30, n.2, p.81-85, 1992.

MARHUENDA, E., MARTIN, M.J., ALARCON DE LA LASTRA, C. Atiulcerogenic activity of aescine in different experimental models. Phytother. Res., Bognor Regis, v.7, p.13-16,1993.

MAIR, A.G.R., PANDIYAN, M., VENKATASUBRAMANIAN, $H$. Polyphenolic compounds from flowers of Psidium guajava. Fitoterapia, Milan, v.58, n.3, p.204-205, 1987.

MARTIN, M. J., ALARCON DE LA LASTRA, C., MARHUENDA, E., DELGADO, F., TORREBLANCA, J. Antiulcerogenicity of flavonoids fraction from Ditrichia viscosa V. Greuter. Phytother. Res., Bognor Regis, v.2, p.895-897, 1995.

MARTIUS , C.F.P. Flora brasiliensis: enumerativo planetarum in Brasilia. Weinheim: J. Cramer, 1967. 
MARUYAMA, Y., MATSUDA, H., MATSUDA, R., KUBO, M., HATANO, T., OKUDA, T. Study on Psidium guajava. (I). Anti-diabetic effective components of the leaf of Psidium guajava. Part. I. Shoyakugaku Zasshi, Tokyo, v.39, n.4, p.261-269, 1985.

MATTOS, Jr.. Britoa ( ${ }^{\circ}$ Berg) Mattos, Subgênero de Campomanesia Ruiz \& Pav. Loefgrenia, v.26, p.5-72, 1967.

MATTOS, J.R. Myrtaceae do Rio Grande do Sul. Roessleria, Porto Alegre, v.5, p. $169-359,1983$.

MATTOS, J.R. Mytaceae do Rio grande do Sul. Roessleria, Porto Alegre, v.6, n.6, p.3-394, 1984.

MATOS, J.M.D., MATOS, M.E. Farmacognosia. Fortaleza: Ed. UFC. 1989, 245p.

MELCHIOR, H. Myrtiflorae (Myrtales): a Engler's Syllabus der Pflaneenfamilien. 12 ed. Berlin: Gebrüder Borntraeger, 1964. v.2, p.345-366.

MENUT, C., VERIN, P., LAMATY, G., BESSIERE, J.M., ENRIQUES, A., VONPOSER, G., SOBRAL, M. Essential oil two Calyptrantes species (Myrtacea). Riv. Ital. EPPOS, Mozzo, spec. num., p.561-565, 1966. (Journees Internationales Huiles Essentielles, 15,1996).

METCALFE, C.R., CHALK, L. Anatomy of dicotyledons, Oxford: Cleredon Press, 1950 , v.1, p.620-631.

METCALFE, C.R., CHALK, L. Anatomy of dicotyledons, Oxford: Cleredon Press, 1972. v.2, p.620-631. 
MEYER, B.N., FERRIGNI, N.R., PUTNAM, J.E., JACOBSEN, L.B., NICHOLS, D.E., MCLAUGHLIN, J.L. Brine shrimp: a convenient general bioassay for active plant constituents. Planta Med., Stuttgart, v.45, n.1, p.31-34, 1982.

MILES, D.H., ROSA, M.J.M., CHITTAWONG, V., HEDIN, P.A., SWITHENBANK. C., LIDERT, Z. 3'-formil-2',4',6'-trihydroxydihychalcone from Psidium acutangulum. Phytochemistry, Oxford, v.30, n.4, p.1131-1132, 1991.

MILLER, T.A. Protective effects of prostaglandins against gastric mucosal damage: current knowledge and proposed mechanisms. Am. J. Physiol., Baltimore, v.245, p.601-23, 1983.

MITSCHER, L.A., DRAKE, S., GOLLAPUDI, S.R., OKNTE, K. A modern look at folkloric use of anti-infective agents. J. Nat. Prod., Columbus, v.50, p.10251040, 1987.

MIZUI, T., DOTEUCHI, M. Effect of polyamines on acidified ethanol-induced gastric lesions in rats. Jpn. J. Pharmacol., Kyoto, v.33, p.939-945, 1983.

MOHAMED, S., HASSAN, Z., HAMID, N.A. Antimicrobial activity of some tropical fruit wastes (guava, starfruit, banana, papaya, passionfruit, langsat, duku, rambutan and rambai). Pertanika J. Trop. Agric. Sci., Selangor, v.17, n.3, p.219-227, 1994.

MORENO, M., RODRIGNEZ, V.M. Yiamoloside B: a fungistatic saponin of Phytolacca octandra. Phitochemistry, Oxford, v.20, p.1446, 1981.

MORIEL, P. Possiveis conexões entre hipertensão e hipercolesterolemia, em relação à aterosclerose: vias de inativação do óxido nítrico e oxidação das lipoproteinas. São Paulo, 2001, 200p. (Tese de Doutorado. Faculdade de Ciências Farmacêuticas -USP) 
MOTILVA, V., ALARCOÓN DE LA LASTRA, C., MARTÍN, M.J. Ulcer-protecting effects of narigenin on gastric lesions induced by ethanol in rat: role of endogenous prostaglandins. J. Pharm. Pharmacol, Wallingford, v.46, p.9194, 1993.

MYAKE, T., SHIBAMOTO, T. Antioxidative activities of natural compounds found in plants. J. Agric. Food Chem., Columbus, v.62, p.2344-2349, 1997.

NAKATANI, N. Phenolic antioxidants from herbs and spices. Bio Factors, Amsterdam, v.13, n.1/4, p.141-146, 2000.

NAMBA, T., YOSHIZAKI, M., TOMIMORI, K., KOBASHI, K., MITSUI, K., HASE, J. Fundamental studies on the evaluation of the crude drugs. Planta Med., Stuttgart, v.25, p.28-38, 1974.

NATIONAL COMMITTEE FOR CLINICAL LABORATORY STANDARS. Methods for dilution antimicrobial susceptibility tests for bacteria that grow aerobiaclly: approved standard-5.ed. Wayne: NCCLS, 2000. v.20, n.2, p.1-31 (NCCLS document M7-A5).

NAVARRETE, A., MIRANDA-TREJO, J. L., REYES-TREJO, L. Principles of root bark of Hippocratea excelsa (Hippocrataceae) with gastroprotective activity. J. Ethnopharmacol., Lausane, v.79, p.383-388, 2002.

NOAMESI, K.B., MENSAH, F.J., BOGALE, M., DAGNE, E., ADOTEY, J. Antiulcerative properties and acute toxicity profile of some African medicinal plants extracs. J. Ethonopharmacol., Lausane, v.42, p.13-18, 1994.

NONAKA, G.I., ISHIMARU, K., WATANABE, M., NISHIOKA, I., YAMAMUCHI, T., WAN, A. Tannins and related compounds: Elucidation of the stereochemistry 
of the triphenoyl moiety in castalagin and vescalagin, and isolation of 1-0galloylcastalagin from Eugena grandis. Chem. Pharm. Bull., Tokyo, v.35, n.1, p.217-220, 1987.

NONAKA, G.I., AIKO, Y., ARITAKE, K., NISHIOKA, A.I. Tannis and related compounds: CXIX. samarangenins $A$ and $B$, novel proanthocyanidins with doubly bonded structures, from Syzygium aqueum. Chem. Pharm. Bull., Tokyo, v.40, n.10, p.2671-2673, 1992.

OLIVEIRA, F.C., AKISUE, G. Fundamentos de Farmacobotânica. 2.ed. São Paulo: Atheneu, 1998, 178p.

ORTEGA, A.G., PINO, J.A., CHANG, L., MARBOT, R., ROSADO, A., GONZALEZ, G. Study of volatile components and sensory profile of four guava cultivars (Psidiun guajava L.). Alimentaria, Madrid, v.35, n.298, p.3135, 1998

OTANI, K., YANAURA, S., YUDA, K.H., KAJITA, T., HIRANO, F., OSAWA, F., INOUYE, S. Histo-chemical studies on the anti-ulcer effect of Bamboo grass in rats. Int. J. Tissue Res., Tokyo, v.12, p. 319-332, 1990.

PAGNOCCA, F.C., PINESSO, M.R., RIBEIRO, L.M. Microbiological assay of Vitamin B6 in some cerrado mineiro plants. Ecletica Quimica, São Paulo, v. 9, p. $41-44,1984$

PAL, S.; CHANDHURI, A.K. Studies on the anti-ulcer activity of Bryophyllum pinnatum leaf extract in experimental animals. J. Ethnopharmacol., Lausane, v.33, p.97-102, 1991. 
PASQUAL, M.E, SLOWING, K., CARRETERO, M.E., VILLAR, A. Antiulcerogenic activity of Lippia alba (Mill). N. E. Brown (Verbenaceae) IL. Farmaco, Lausane, v.56, p.501-504, 2001.

PATCHER, H.M. Magic into Science. Henry Shuman, 1951. New York. APUD: CORDELL, G.A. Biodiversity and Drug discovery a Symbiotic relationship. Phytochemistry, Oxford, v.55, p.463-480, 2000.

PEARSON, J., ALLEN, A., VENABLES, C. Gastric mucus: isolation and polymeric structure of the undergraded glycoprotein: its breakdow by pepsin. Gastroenterology, Orlando, v.78, p.709-715, 1980.

POLYGENIS-BIGENDAKO, M.J., LEJOLY, J. Plants used in the treatment of diarrheas in traditional medicine in westem Burundi. Bull. Soc. R. Bot. Bel., Brussels, v.122, n.1, p.87-97, 1989

POURGHOLAMI, M.H., KAMALINEJAD, M., JAVADI, M., MAJZOOB, S., SAYYAH, M. Evaluation of the anticonvulsant activity of the essential oil of Eugenia caryophyllata in male mice. J. Ethnopharmacol., Lausane, v.64, n.2, p.167-171, 1999.

PRATES, L.M.A., ORTEGA, G.G., SCHENQUKEL, P.P. Chemical assays and chromatographic analysis of tannin content in Gomidesia palustris (DC.) Kausel (myrtaceae). Rev. Bras. Farm., Rio de Janeiro, v.76, p.12-16, 1995.

PRATT, D.E., MILLER, E.E. A flavonoid antioxidant in spaish peanuts. J. Am. Oil Chem. Soc., Champaing, v.61, n.6, p.1064-1067, 1984.

PRIYADARSINI, K.I., GUHA, S.N., RAO, M.N.A. Phisico-chemical properties and antioxidant activities of methoxy phenols. Free Radical Biol. Med., New York, v. $24, n^{\circ} 6, p .933-941,1998$. 
RABE, T., VAN-STADEN, J. Antibacterial activity of South African plants used for medicinal purposes. J. Ethnopharmacol., Lausane, v.56, n.1, p.81-87, 1997.

RABENHORST, J. Production of metoxyphenol-type natural aroma chemicals by biotransformation of eugenol with a new Pseudomonas sp. Appl. Microbiol. Biotechnol., Berlin, v.46, n.5/6, p.470-474, 1996.

RAFATULLAH, S., TARIQ, M., MOSSA, J.S., AL-YAHYA, M.A., AL-SAID, M.S. Protective effect of Swertia chirata against indometacin and other ulcerogenic agent-induced gastric ulcers. Drugs Exp. Clin. Res., Geneva, v.19, p.69-73, 1993.

RAFATULLAH, S., GALAL, A.M., AL-YAHYA, M.A., AL-SAID, M.S. Gastric and duodenal antiulcer and cytoprotective effects of Aframomum melegueta in rats. Int. J. Pharm., Lisse, v.33, p.311-316, 1995.

RAJASEKARAN, M., BAPNA, J.S., LAKSHMANAN, S., NAIR, A.G.R., VELIATH, A.J., PANCHANADAM, M. Antifertility effect in male rats of oleanoic acid, a triterpene from Eugenia jambolana flowers. J. Ethnopharmacol., Lausane, v. 24, n. 1, p.115-121, 1988.

RAMANOELINA, A.R.P., TERROM, G.P., BIANCHINI, J.P., COULANGES, P. Contribution to the study of the antibacterial activity of some essential oils extracted from Madagascar plants. Arch. Inst. Pasteur Madagascar, Tananarive, v.53, n.1, p.217-226, 1987.

RAMIREZ, C.A., HERNANDEZ, O.V., MARTINEZ, M.I. Ovarian development in Anastrepha striata schiner (Diptera: Tephritideae). Acta Zool. Mex.: Nueva Ser. México, v.69, p.105-116, 1996. 
RAO, C.B., SURYAPRAKASAM, S. Cardamonin and alpinetin from the seeds of Amomum subulatum. Planta Med., Stuttgart, v.29, p.391-392, 1976.

RENAUD, S., DE LORGERID, M. Wine, alcohol, platelets and the french paradox for coronary heart disease. Lancet, London, v.339, p.1523-1526, 1992.

RESOLUÇÃO-RDC No 17 de 24 de fevereiro de 2000. Diário Oficial da Uninão, Brasilia, Seção 1, n 40, p.25, 25 de fevereiro de 2000.

RICE-EVANS, C. A., MILLER, N.J., PAGANGA, G. Structure-antioxidant activity relationship of flavonoids and phenolic acids. Free Radical Biol. Med., New York, v.20, p.933-956, 1996.

RICE-EVANS, C. A., Flavonoids in Health and Disease. New York, Marcel Dekker INC, 1998, p.118-177.

RIOS, J.L., RECIO, M.C., VILLAR, A. Screening methods for natural products with antimicrobial activity: Review of the literature. J. Ethonopharmacol., Lausane, v.20, p.127-149, 1988.

ROBERT, A., NEZAMIS, J.E., LANCASTER, C., HAUCHAR, A.J. Gastric cytoprotective property of prostaglandins. Gastroenterology, Orlando, v.72, p. 1121,1977

RODRIGUEZ, M., GARCIA, D., GARCIA, M., PINO, J., HERNANDEZ, L. Antimicrobial activity of Pimenta dioica. Alimentaria, Madrid, v.34, n.274, p.107-110, 1996.

ROSS, R. The pathogenesis of atherosclerosis-an update. N. Engl. J. Med., Boston, v.314, p.488-500,1986. 
ROTMAN, A., JUAREZ, B.E., MENDIONDO, M.E. Blepharocalyx salicifolius a member of the Argentine flora: Chemosystematic contribution of the identy of $B$, tweediei and B. Gigantea (Myrtaceae). Lilloa, Tucuman, v.39, n.2, p.201$203,1998$.

SAIJA, A., SCALESE, M., LANZA, M., MARZULLO, D., BONINA, F., CASTELLI, F. Flavonoids as antioxidant agents: Imporatnce of their interação with biomembranes. Free Radical Biol. Med., New York, v.19, n.4, p.481-486, 1995.

SAIRAN, K., RAO, V.C., BABU, D. M., GOEL, R.K. Prophylatic and curative effects Bacopa monniera in gastric ulcer models. Phytomedicine, Jena, v.8, n.6, p.423-430, 2000.

SANTOS, F.A., RAO, V.S., SILVEIRA, E.R. The leaf essential oil of psidiun guyanensis offers protection against pentylenetetrazole induced seizures. Planta Med., Stuttgart, v.63, n.2, p.133-135, 1997.

SANTOS, F.A., RAO, V.S., SILVEIRA, E.R. Anti-inflammatory and analgesic activities of the essential oli Psidium guianense. Fitoterapia, Milan, v.68, n.1, p.65-68, 1997.

SARKS, T., MODOW, C.F., CRADDOCK, P.R., BOWER, T.K., JACOB, H.S. Oxigen radicals mediate endothelial damage complement-stimulated granulocytes. J. Clin. Invest., Ann Arbor, v.61, p.1161-1167, 1978.

SASS, J.E. Botanical microtechnique. 2.ed. Ames: lowa State College Press, $1951,391 p$.

SCALBERT, A. Antimicrobial properties of tannins. Phitochemistry, Oxford, v.30, n.12, p.3875-3883, 1991. [Review]. 
SCHAPOVAL, E.E.S., SILVEIRA, S.M., MIRANDA, M.L., ALICE, C.B., HENRIQUES, A.T. Evaluation of some pharmacological of Eugenia uniflora L. J. Ethnopharmacol., Lausane, v.44, n.3, p.137-142, 1994.

SETZER, W.N., SETZSER, M.C., MORIARITY, D.M., BATES, R.B., HABER, W.A. Biological activity of the essential oil of Myrciantes sp, nov. "black fruit" from Monte Verde, Costa Rica. Planta Med., Stuttgart, v.65, n.5, p.468-469, 1999.

SHASHI, B.M., SARKAR, K.S., PODDAR, G. Triterpenoid saponins. Phytochemistry, Oxford, v.27, n.10, p.3037-3067, 1988. [Review article number 38].

SCHMEDA-HIRSCHMANN, G. Flavonoids from Calycorectes, Campomanesia, Eugenia and Hexachlamys species. Fitoterapia, Milan, v.66, n.4, p.373-374, 1995.

SCHEMEDA-HIRSCHMANN, G., THEODULOZ, C., FRANCO, L., FERRO, B.E., DE-ARIAS, A.R. Preliminary pharmacological studies on Eugenia uniflora leaves: xanthine oxidase enhibitory activity. J. Ethnopharmacol., Lausane, v.21, n.2, p.183-186, 1987.

SIMÕES, C.M., MENTEZ, L.A., SCHENKEL, E.P., IRGANG, B.E., STEHMAN, J.R. Plantas da medicina popular no Rio Grande do Sul, 3 ed., Porto Alegre, Edunisul, 1989,p.86-87.

SLOBODAN, V.J., STEENKEN, S., TOSIC, M., MARJANOVIC, B., SIMIC, M. Flavonoids as antioxidants. J. Am. Chem. Soc., Washington, v.116, n.11, p.4846-4852, 1994. 
SLOWING, K., CARRETERO, E., VILLAR, A. Anti-inflammatory activity of leaf extracs of Eugenia jambos in rats. J. Ethnopharmacol., Lausane, v.43, n.1, p.9-11, 1994.

SNEADER, W. Drug Discovery: The evolution of modern medicines, Wiley, Chichester. Apud: CORDELL, G.A. Biodiversity and drug discovery- a symbiotic relationship. Phytochemistry, Oxford, v.55, p.463-480, 2000.

SOLIS, P.N., WRIGHT, C.W., ANDERSON, M.M., GUPTAM. P., PHILLIPSON, J.D. Amicrowell cytotoxicity assay using Artêmia salina (Brine Shrimp). Planta Méd., Stuttgart, v.59, p. 250-252, 1993.

SOUZA-BRITO, A.R.M., SOUZA-BRITO, A.A. Forty years of Brasilian medicinal research. J. Ethnopharmacol., Lausane, v.39, p.53-67, 1993.

SOUZA-FORMINGONI, M.L., DLINERIVA, M.G., MONTIRO, M.G., SILVEIRAFILHO, N.G., BRAZ, S., CARLINI, E.A. Anti-ulcerogenic effects of two Maitenus species in laboratory animals. J. Ethnopharmacol., Lausane, v.34, p.21-27, 1991.

STOCKS, J., GUTTERIDGE, J.M.C., SHARP, R.J., DORMANDY, T.L. Assay using brain homogenate for measuring the antioxidant activity of biological fluids. Clin. Sci. Mol. Med., Oxford, v.47, p.215-222, 1974.

SUN, X.B., MATSUMOTO, T., YAMADA, H. Effects of a polysaccharide fraction from the roots of Bupleunum falcatum $L$ on experimental gastric ulcer models in rats and mice. J. Pharm. Pharmacol., Wallingford, v.43, p.699-704, 1991.

TAKAHAMA, V. Inhibition of lipoxygenase-dependent lipid peroxidation by quercetin: mechanism of antioxidative function. Phytochernistry, Oxford, v.24, p.1443-1446, 1985 
TAKANO, F., YOSHIZAKI, F., SUZUKI, K., SUYA, N., ANDO, T., HISAMICHI, S. Anti-ulcer effects of trichosanthes fruits. Chem. Pharm. Bull., Tokyo, v.38, p.1313-1316, 1990.

TAKEUCHI, D.J., NOBUHARA, Y. Inhibition of gastric motor activity by 16,16 dimethyl-prostaglandin E2: a provable explanation of cytoprotection. Dig. Dis. Sci., v.30, p.1181-1188, 1985

TANAKA, T., ISHIDA, N., ISHIMATSU, M., NONAKA, G.I., NISHOKA, I. Tannins and relates compounds CXVI. six new complex tannins, guajavins, psidinins and psiguavin from the bark of Psidiun guajava $L$. Chem. Pharm. Bull., Tokyo, v.40, n.8, p.2092-2098, 1992.

THEODULOZ, C., FRANCO, L., FERRO, E., SHEMEDA-HIRSCHMANN, G., Xantine oxidase inhibitory activity of Chilean Myrtaceae. J. Ethnopharmacol., Lausane, v.24, n.2-3, p.179-184, 1988.

TONA, L., KAMBU, K., NGIMBI, N., MESIA, K., PENGE, O., LUSAKIBANZA, M., CIMANGA, K. Antiamoebic and spasmolytic activities of extracts from some antidiarrhoeal traditional preparations used in Kinshasa, Congo. Phytomedicine, Jena, v.7, n.1, p.31-38, 2000.

VILLARREAL, M.L., ALONSO, D., MELESIO, G., Cytotoxic activity of some Mexican plants used in traditional medicine. Fitoterapia, Milano, v.63, n.6, p.518-522, 1992.

WADT, N., OHARA, M.T., SAKUDA-KANEKO, T.M., BACCHI, E.M. Atividade antimicrobiana de Leonurus sibincus L. Rev Brás. de Farmacogn., São Paulo, v.5, n.2, p.143-232, 1996. 
WAGNER, M., BLADT, S. Plant drug analysis: a thin layer chromatography atlas. 2.ed. Berlin: Springer,1996, 320 p.

WASIKY, R., AKISUE, G. Um aparelho aperfeiçoado para a extração de óleos essenciais. Rev Farm. Bioquím. Univ. São Paulo, São Paulo, v.7,n.2, p.339-405, 1959.

WHEAT, P.F. History and development of antimicrobial susceptibility testing methodology. J. Antimicrob. Chemother. , v.48, Suppl. p.1-4, 2001.

WORLD HEALTH ORGANIZATION. Quality assurance of pharmaceuticals a compendium of guidelines and related materials. Geneva, v..I, p.31-37, 1997.

YAMADA, H., HIRANO, M., KIYOHARA, $H$. Partial struture of anti-ulcer pectic polysaccaharide from the roots of Bupleurum falcatum L. Carbohydr. Res.; Amsterdam, v.219, p.173-192, 1991.

YANG, L.L., LEE, C.Y., YEN, K.Y. Induction of apoptosis by hydrolyzable tannins from Eugenia jambos L. on human leukemia cells. Cancer Lett., Shannon, v. 157, n. 1, p.65-75, 2000.

YOSHIKAWA, M., SHIMADA, H., NISHIDA, N., LI, Y., TOGUCHIDA, I., YAMAHARA, J., MATSUDA, $H$. Antidiabetic principles of natural medicines. II aldose reductase and a-glucosidase inhibitors from Brazilian natural medicine, the leaves of Myrcia multiflora DC (Myrtaceae) structures of myrciacitrins I e II and myrcianphenones A and B. Chem. Pharm. Bull., Tokyo, v.46, n.1, p.113$119,1998$.

ZANI, F., CARMELLINO, M.L. Antimicrobial and geotoxic properties of quinoline derivates. Boll. Chim. Farm., Milan, v.122, n.4, p.328-338, 1994. 
ZAPATA, S.M., DUFOUR, J.P. Camu-camu Myrciania dubia (HBK) Mc Vaugh: Chemical composition of fruit. J. Sci. Food Agric., Bognor Regis, v.61, n.3, p.349-351, 1993.

ZHENG, G.O., KENNEY, P.M., LAM, L.K.T. Sesquiterpenes from clove (Eugenia caryophyllata) as potential anticarcinogenic agents. J. Nat. Prod., Columbus v.55, n.7, p.999-1003, 1992. 